\title{
Interaction of Dams and Landslides—Case Studies and Mitigation
}

By Robert L. Schuster

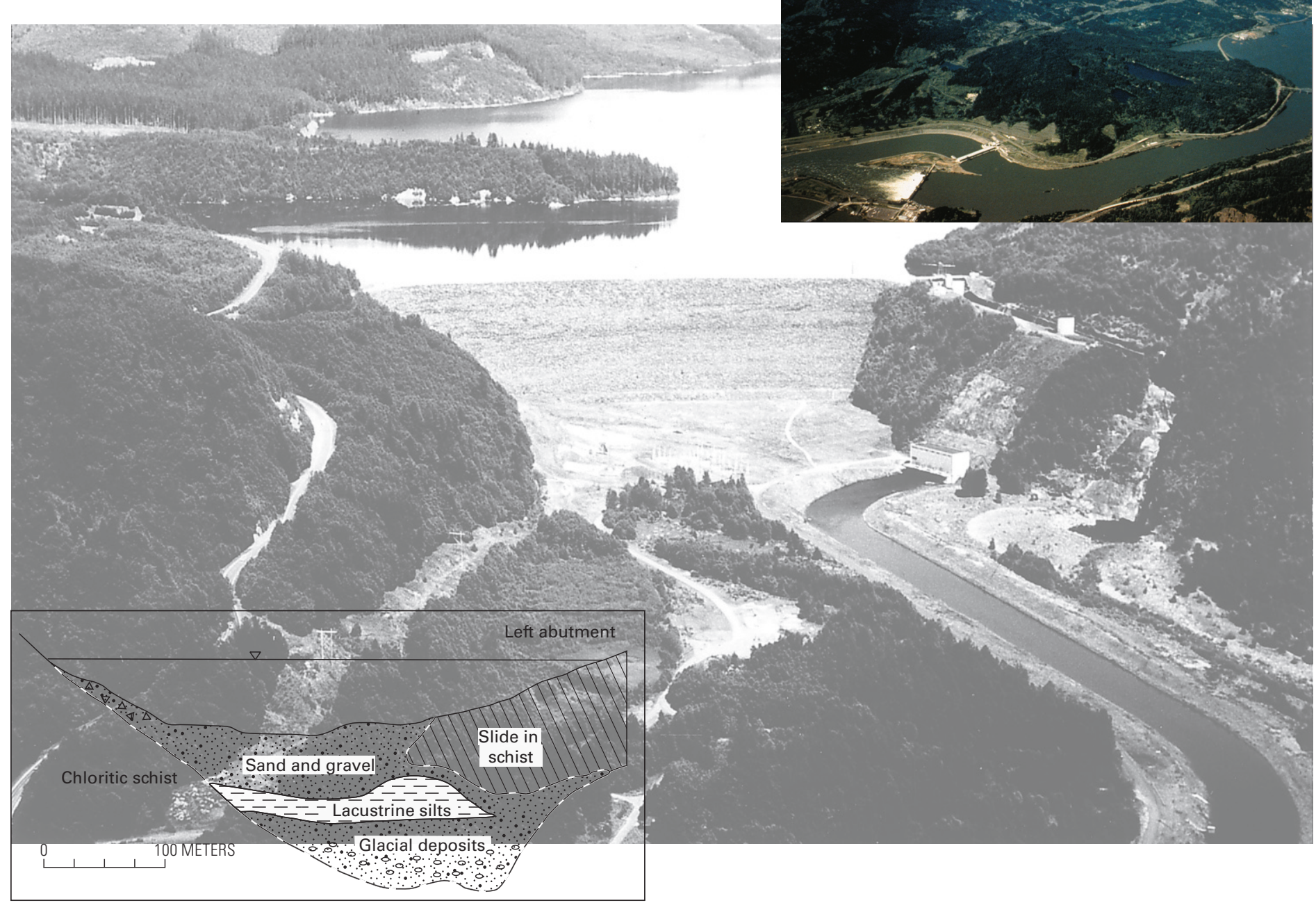

Professional Paper 1723 
Cover--Aerial view of Swift Dam, Lewis River, western Washington State, United States (photograph taken by Lynn Topinka, U.S. Geological Survey).

Top inset.-Bonneville Dam, Columbia River Gorge, Washington and Oregon, United States (photograph taken by Derek Cornforth, Landslide Technology, Portland, Oregon).

Bottom inset.-Cross section through rock slide, Durlassboden Dam, Austria (modified from Záruba and Mencl, 1982). 


\section{Interaction of Dams and Landslides-Case Studies and Mitigation}

By Robert L. Schuster

Professional Paper 1723

U.S. Department of the Interior

U.S. Geological Survey 


\section{U.S. Department of the Interior DIRK KEMPTHORNE, Secretary}

\section{U.S. Geological Survey \\ Mark D. Myers, Director}

\section{U.S. Geological Survey, Reston, Virginia: 2006}

For product and ordering information:

World Wide Web: http://www.usgs.gov/pubprod

Telephone: 1-888-ASK-USGS

For more information on the USGS--the Federal source for science about the Earth, its natural and living resources, natural hazards, and the environment:

World Wide Web: http://www.usgs.gov

Telephone: 1-888-ASK-USGS

Any use of trade, product, or firm names is for descriptive purposes only and does not imply endorsement by the U.S. Government.

Although this report is in the public domain, permission must be secured from the individual copyright owners to reproduce any copyrighted materials contained within this report.

Suggested citation:

Schuster, R.L., 2006, Interaction of dams and landslides-Case studies and mitigation: U.S. Geological Survey Professional Paper 1723, 107 p. 


\section{Contents}

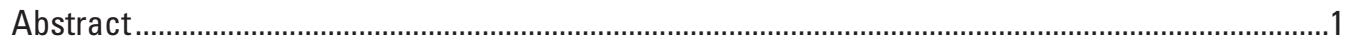

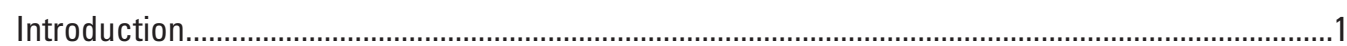

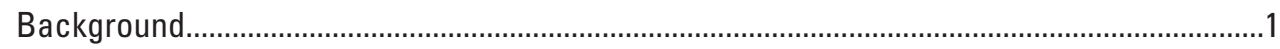

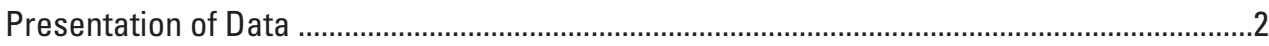

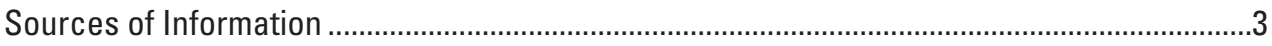

Summary of Data..............................................................................................................

Selected Case Histories of Dams on Landslides (by Landslide Type)...............................................

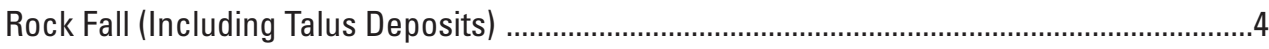

Slides in Competent Rock .....................................................................................................

Slides in Incompetent rock ..................................................................................................13

Massive Rock Slides and Glide Blocks ................................................................................13

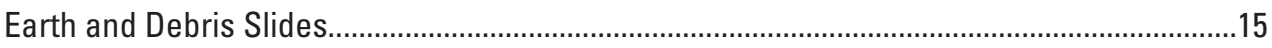

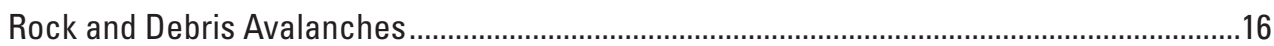

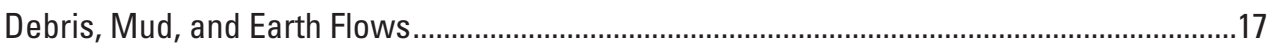

Cambering and Valley Bulging........................................................................................22

Problems Encountered Due to Interaction Between Dams and Landslides ...................................22

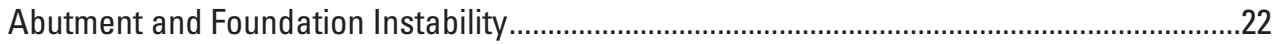

Abutment and Foundation Seepage ...............................................................................2

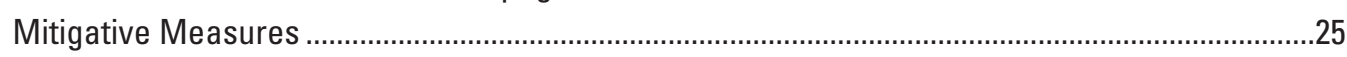

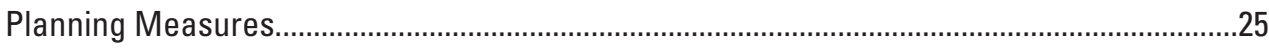

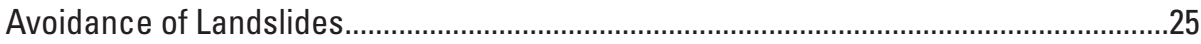

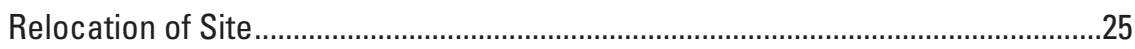

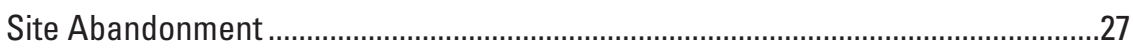

Redesign of Dams Because of Landslide Problems ........................................................27

Lowering Reservoir Level or Reducing Rate of Filling ..................................................28

Physical Measures for Foundation and Abutment Stabilization......................................................28

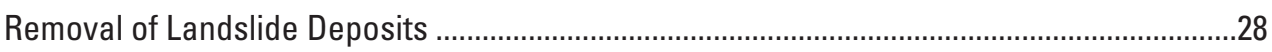

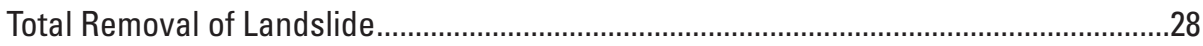

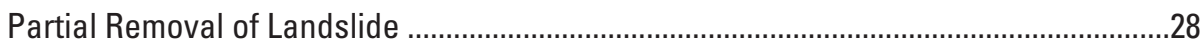

Partial Removal of Talus Cover ...................................................................................29

Partial Removal of Landslide Deposit Following Construction or

Postconstruction Slope Failure ...........................................................................29

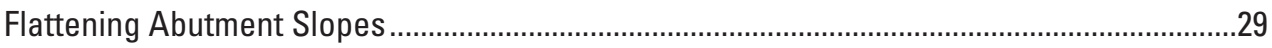

Earthfill or Rockfill Berms Serving as Buttresses ............................................................29

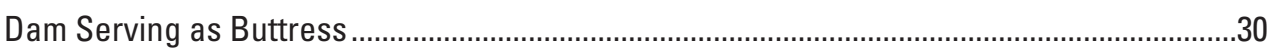

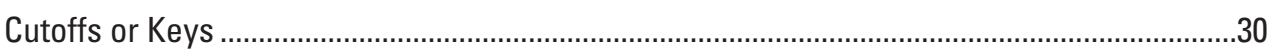

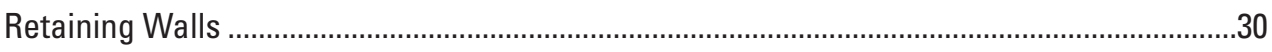

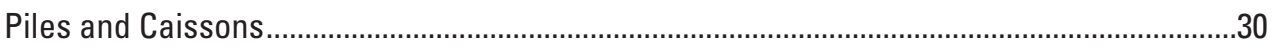

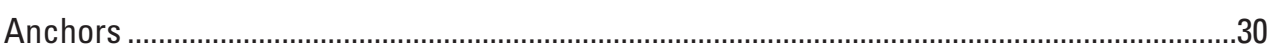

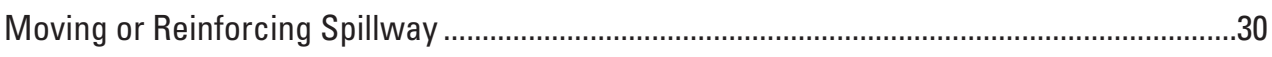

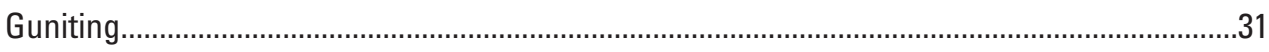

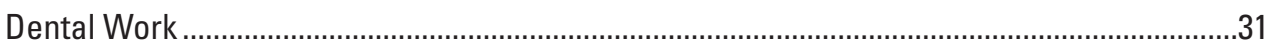


Physical Measures for Reducing Abutment and Foundation Seepage..............................................31

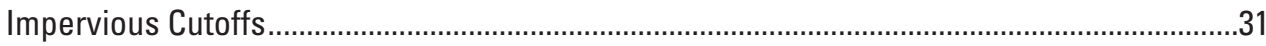

Impervious Curtains, Membranes, and Blankets ……………..............................................

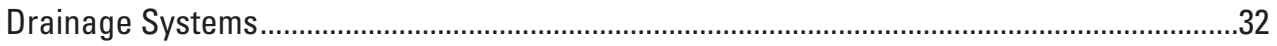

Multiple Mitigation Methods ............................................................................................

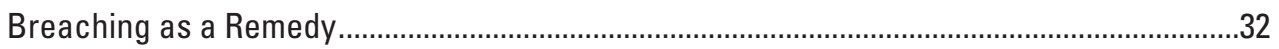

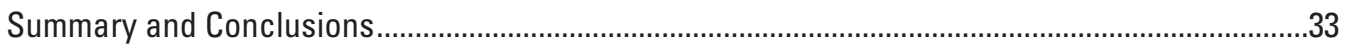

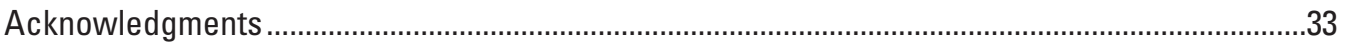

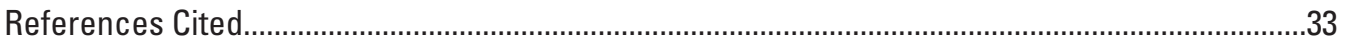

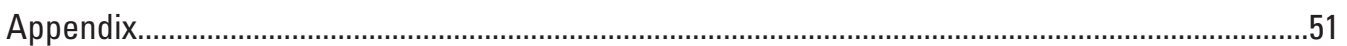

\section{Figures}

1. Original sketch map and cross section showing landslide conditions at Farmers Union (now Rio Grande) Dam, southwestern Colorado,

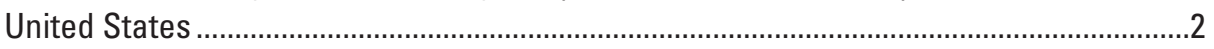

2. Photograph of Mammoth Pool Dam, San Joaquin River, California, United States ...........5

3. Cross section through the narrow gorge in the foundation of Waterbury Dam, Little River, Vermont, United States

4. Views before and after construction of Taylor Park Dam, central Colorado, United States

5. Gross Dam, Colorado, United States

6. Gravity-slip surfaces in granitic foundation rocks at Gross Dam, Colorado Front Range, United States

7. Photograph looking upstream at the remains of St. Francis Dam, southern California, United States.

8. Cross section through the 1928 left-abutment landslide at St. Francis Dam, California, United States.

9. Cross section through the pre-existing rock slide that forms the left abutment of Beauregard Dam, northwestern Italy

10. Simplified cross-valley cross section through Dalešice Dam, Jihlava River, Czech Republic.

11. Oblique view of Tablachaca Dam, Peru

12. Photograph looking upstream at the right-abutment landslide at Tablachaca Dam, Peru.

13. Map of rock slide at the right abutment of Tablachaca Dam, Peru ...............................10

14. Photograph of Lake Harriet Dam, Cascade Range, Oregon, United States.....................10

15. Major Holocene landslide deposits in the Columbia River Gorge, Washington and Oregon, United States

16. Oblique aerial view of Bonneville Dam in the Columbia River Gorge, Washington and Oregon, United States

17. Map of the Cascades landslide complex and its components, United States................12

18. Simplified cross section through the rock slide in schist that forms the right abutment of Durlassboden Dam, Austria

19. Photograph of Fruitgrowers Dam, western Colorado, United States ... 
20. Locations of 18 dams on landslide bench and slump-block landslides derived from the basalt plateau of the Grand Mesa, western Colorado, United States. . .14

21. Photograph of Grand Coulee Dam, eastern Washington State, United States................15

22. Cross section through the Parangana Dam site, Victoria, Australia ...............................16

23. Oblique aerial view of Cheakamus Dam, British Columbia, southwestern Canada ........17

24. Cross section through the site of Cheakamus Dam, British Columbia, southwestern Canada

25. Aerial-oblique view of Mud Mountain Dam, western Washington State, United States.

26. Cross section through the site of Mud Mountain Dam, Washington State, United States

27. Aerial view of Swift Dam, Lewis River, western Washington State, United States.

28. Geologic map of the area around Swift Dam, Washington State, United States.

29. Geologic map of the area around Yale Dam and Yale Saddle Dam, Washington State, United States

30. Sketch of the earthfill sediment-retention dam on the North Fork Toutle River, southwestern Washington State, United States

31. Photograph of Medeo Dam, a debris-flow retention structure on the Malaya Alma-Atinka River, Kazakhstan

32. Photograph of construction of a cellular reinforced-concrete debris-retention dam on the Bolshaya Alma-Atinka River, Kazakhstan . .21

33. Cross section through B.F. Sisk (San Luis) Dam, California, United States .....................23

34. Photograph of Cheurfas Dam .................................................................................23

35. Photograph of Star Mountain Dam, southeast Oregon, United States ...........................24

36. Oblique-aerial view of Ochoco Dam, central Oregon, United States ..............................24

37. Cross section through the site of Howard Hanson Dam, western

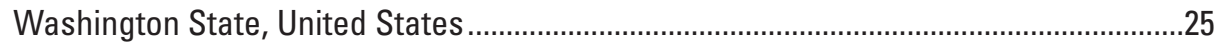

38. Photograph of Scott Dam on the Eel River, northern California, United States ...............26

39. Cross section through a narrowed section of the Romanche River valley, France...

40. Oblique view of the left end of Mojave River Dam ..........................................................29

41. Photograph of the remains of Mystic Lake Dam, southwestern Montana, United States.

\section{Tables}

Appendix Table A. Dam characteristics, relation to landslides, mitigative measures, and cited references. 


\title{
Interaction of Dams and Landslides-Case Studies and Mitigation
}

\author{
by Robert L. Schuster
}

\section{Abstract}

In the first half of the 20th century, engineering geology and geotechnical engineering were in their infancy, and dams were often built where landslides provided valley constrictions, often without expert site investigation. Only the most important projects were subjected to careful geologic examination. Thus, dams were often built without complete understanding of the possible geotechnical problems occurring in foundations or abutments. Most of these dams still exist, although many have undergone costly repairs because of stability or leakage problems. Today, however, every effort is made in the selection of damsites, including those sited on landslides, to provide foundations and abutments that are generally impervious and capable of withstanding the stresses imposed by the proposed dam and reservoir, and possible landslides.

By means of a literature search, technical interviews, and field inventory, I have located 254 large (at least $10 \mathrm{~m}$ high) dams worldwide that directly interact with landslides; that is, they have been built on pre-existing landslides or have been subjected to landslide activity during or after construction. A table (Appendix table A) summarizes dam characteristics, landslide conditions, and remedial measures at each of the dams. Of the 254 dams, 164 are earthfill, 23 are rockfill, and 18 are earthfill-rockfill; these are flexible dam types that generally perform better on the possibly unstable foundations provided by landslides than do more rigid concrete dams.

Any pre-existing landslides that might impinge on the foundation or abutments of a dam should be carefully investigated. If a landslide is recognized in a dam foundation or abutment, the landslide deposits commonly are avoided in siting the dam or are removed during stripping of the dam foundation and abutment contacts. Contrarily, it has often been found to be technically feasible and economically desirable to site and construct dams on known landslides or on the remnants of these features. In these cases, proven preventive and remedial measures have been used to ensure the stability of the foundations and abutments, and to reduce seepage to acceptable levels.

\section{Introduction}

This paper presents case histories of dams that have interacted with landslides in abutments and/or foundations. It uses these case histories to discuss problems caused by different types of landslides and mitigative measures used to alleviate these problems. Note that interactions between reservoirs and landslides are beyond the scope of this paper. Thus, wellknown cases of reservoir-induced landslides such as those at Vaiont Dam and Grand Coulee Dam's Lake Roosevelt are not included.

\section{Background}

\begin{abstract}
"Many major slides have in the past blocked up river valleys, the resulting constrictions giving dam sites which appear at first sight to be admirable. In view of the of the nature of the material in slides, and its unconsolidated and often disturbed conditions, sites of this kind may often prove to be very far from ideal. Dams have, however, been successfully founded at such sites" (Legget, 1939, p. 225-226).
\end{abstract}

"No structure grips the ground so closely as a dam. It holds on at its base and at its flanks***. In other words, a dam is made up of two parts: the artificial dam, man-made, and the natural dam, which continues it, surrounds it, and on which it is founded. The more important of the two is the latter which is unnoticed" (Martin, 1974, translated from Coyne, 1939).

From Coyne's statement it can be further inferred that any movement, or potential movement, of the foundation or an abutment ${ }^{1}$ is critical to the stability and effectiveness of the dam itself. Thus, the possibility of gravitational

'I will use dam "foundation" as being the rock/soil in direct contact with the base of the dam, and dam "abutments" to be the parts of the valley side slope that are in direct contact with the ends of the dam. Together, the foundation and abutments form the "footprint" of the dam. 
movement (landslide ${ }^{2}$ activity) in the foundation or an abutment of a dam is of critical importance. Because many (if not most) such movements are reactivations of all or parts of preexisting landslides, it is extremely important to identify these morphological elements and to realize their possible effects on the dams involved. As noted by Weaver (1989), "Landslides, if recognized prior to construction, presumably are avoided or are removed during stripping of the dam foundation. However, landslides of significant size sometimes occur during the course of stripping operations for a dam on weak rock foundations, and must be left in place."

In the early part of the 20th century, a few experts recognized and presented the problems posed by pre-existing landslides in dam foundations or abutments (see for example, Clarke, 1904; Lapworth, 1911; Atwood, 1918, (his fig. 1); Willis, 1928; Bromehead, 1936; and Legget, 1939). However, in spite of this technical expertise and warning, many, if not most, dams were built without expert examination of damsites; only the most important projects were subjected to careful geologic studies. Thus, dams were often built without complete understanding of the possible geotechnical problems inherent in their abutments or foundations. Today, however, every effort is usually made to select a damsite in which the abutments and foundation are relatively impervious and capable of withstanding the stresses imposed by the proposed dam and reservoir under all probable loading conditions. Thus, permeability and stability of dam abutments and foundations must be considered during site selection, site preparation, construction, and operation of dam structures (Záruba, 1979; Weaver, 1989).

Many post-World War II geologists and engineers have discussed in depth the importance of understanding the existence of landslides at damsites. Among the most noteworthy works have been those of Burwell and Moneymaker (1950), Gignoux and Barbier (1955), Richey $(1959,1964)$, Walters (1971), Desio (1973), Barbier (1974), Martin (1974), Anderson and Trigg (1976), Záruba and Mencl (1976, 1982), Mencl (1977), Záruba (1979), Hobst and Zajíc (1983), Legget and Karrow (1983), Legget and Hatheway (1988), Galster (1989a,b), Fell and others (1992), Skempas and Chandler (1993), Tolmachev (1994), and Riemer (1995).

It has often been found to be technically feasible and economically desirable to site and construct dams on known landslides or on their partial remnants after most of the material has been stripped from the site. The stability of the landslide or its remnant can be enhanced by the buttressing effect of the dam itself, which can be augmented by berms acting as buttresses, by anchors, or by retaining structures. In addition, problems caused by seepage through the landslide materials usually can be remedied by means of surface or subsurface drains, grout curtains, impervious membranes, or other preventive or remedial measures.

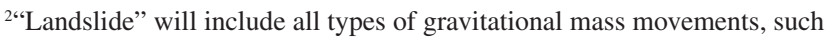
as falls, slides, avalanches, and flows, according to the landslide classifications of Varnes (1978) and Cruden and Varnes (1996).
}
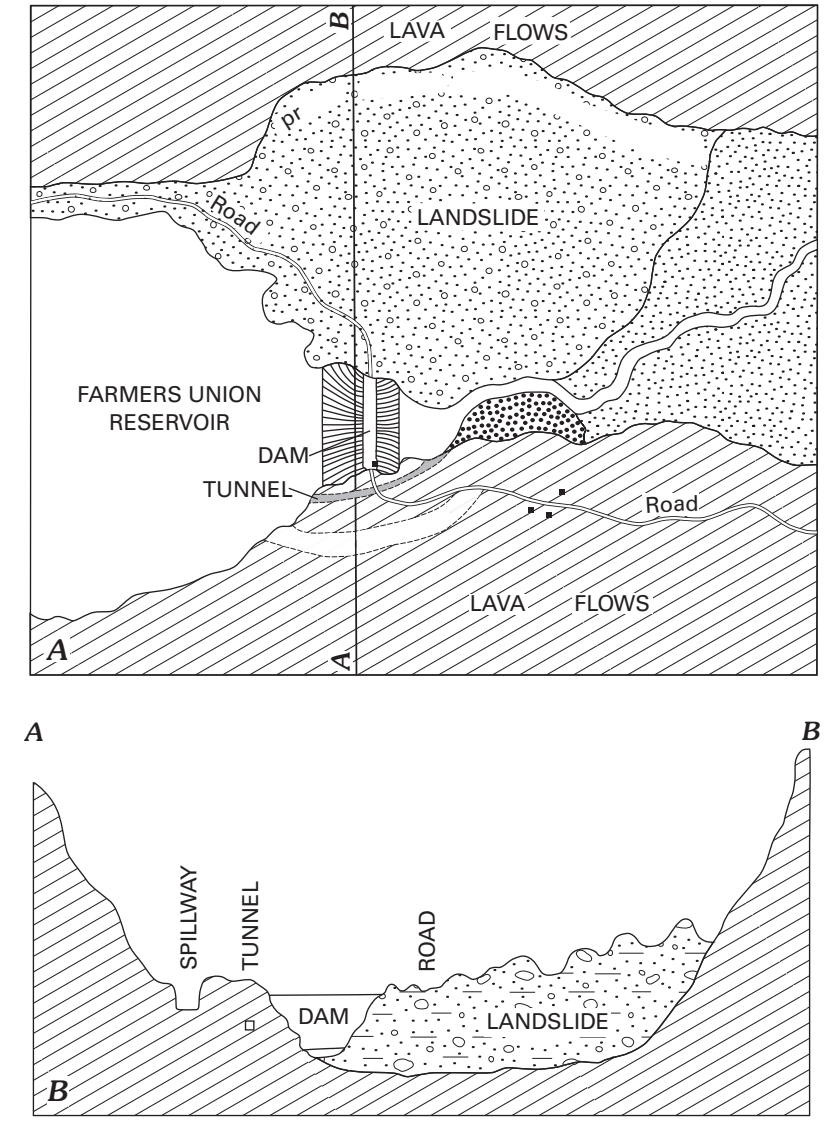

Figure 1. Original sketch map $(A)$ and cross section $(B)$ along the line $A-B$, showing landslide conditions at Farmers Union (now Rio Grande) Dam, southwestern Colorado, United States (Atwood, 1918, p. 19).

\section{Presentation of Data}

Appendix table A presents the cases of 254 large $^{3}$ dams that were identified in this worldwide survey of dams built on (1) pre-existing landslides, (2) remnants of partly excavated landslides, and (3) construction-caused or post-construction landslides. It includes only cases in which part or all of the landslide was left in place as part of the foundation or an abutment. The table includes data for a few dams that no longer exist. Each case includes the location, dam and stream names, dam type and purpose, year of dam completion and owner, dam and reservoir dimensions, landslide type and position, comments regarding the landslide and remedial measures, and

3For cases in which "the dam had specially difficult foundation conditions," the International Commission on Large Dams (ICOLD) defines a "large" dam as one that is at least $10 \mathrm{~m}$ high (International Commission on Large Dams, 1977). Because most dams constructed on landslides fit this specification, I will use $10 \mathrm{~m}$ as the minimum height for "large" dams. All dams in Appendix table A are $10 \mathrm{~m}$ high or higher, and thus all are "large" dams. 
references and other information sources. The purpose of this tabulation is to provide observations and conclusions to aid in future dam-siting decisions.

Some, but not all, of the dams in Appendix table A are also discussed as examples of the basic types of landslides on which dams have been built, as examples of the common problems encountered from interaction of dams and landslides, or as examples of the types of mitigation measures that have been used to solve or reduce problems related to dam and landslide interaction.

\section{Sources of Information}

The data presented in Appendix table A have been obtained from the following sources:

- Technical papers, reports, and textbooks appearing in the international geological, geotechnical, and damengineering literature

- Government dam-building agencies and consulting companies, mostly in North America

- Geotechnical consultants and colleagues with experience on dams and landslides, mostly in the United States

- Local, State, and Federal dam-safety agencies in the United States

- Personal experience of the author, including visits to nearly all of the U.S. dams listed, as well as several of the foreign dams

Information on dams located outside the United States has been obtained mainly from a detailed search of the international landslide and dam literature. Especially valuable were proceedings of congresses and specialty conferences of the International Commission on Large Dams (ICOLD), the International Association for Engineering Geology and the Environment (IAEG), the International Society for Soil Mechanics and Geotechnical Engineering (ISSMGE, formerly known as the International Society for Soil Mechanics and Foundation Engineering), the American Society of Civil Engineers (ASCE), the Association of Engineering Geologists (AEG), and other sources. Also perused were professional journals, such as Geotechnique, The Quarterly Journal of Engineering Geology, the Journal of Geotechnical Engineering, Environmental and Engineering Geoscience, and Engineering Geology. United States proceedings included those of the annual meetings of the U.S. Society on Dams (USSD, formerly known as the U.S. Committee on Large Dams) and the Association of State Dam Safety Officials (United States). Physical data on dams in the United States were obtained from the CD-ROM, National Inventory of Dams 1996 (Federal Emergency Management Agency, 1996), which includes 76,000 U.S. entries. Landslide information on U.S. dams came partly from published technical papers, partly from the files of
Federal dam agencies and State dam-safety organizations, and partly from interviews with professional colleagues in government agencies, universities, and consulting companies. In addition, the author visited nearly all of the U.S. dams entered in the table, as well as several foreign dams, often in the company of local dam officials and personnel. The source(s) of information for each dam is indicated in the last column of Appendix table A.

\section{Summary of Data}

Of the 254 dams in the study, 153 are located in the United States; 142 of these are in the conterminous Western States (including, or west of, the Rocky Mountains). The State of Colorado leads the list with 56 dams on landslides (Schuster, 2003), followed by California with 21, Oregon with 18 , Utah with 16, and Washington with 14 . For the rest of the world, Italy leads with 11 dams, followed by Australia with 7, India, Japan, and the United Kingdom with 6 each, and the Czech Republic and Spain with 5 each. This seeming bias in gathering of data for the Western United States (as compared to that for the rest of the world) probably occurs because of (1) the very large number of dams that have been built in the Western United States, (2) the great number of landslides in the mountains of the Western United States, and (3) the fact that I have closer technical and professional contacts in the Western United States than elsewhere in the world-contacts who have been willing to supply research data to this study. In addition, in the United States, many data were obtained as public information from State dam-safety agencies, an opportunity that did not present itself for other countries. Instead, almost all non-United States case histories were obtained from published papers in technical journals and proceedings. This latter fact also resulted in a preponderance of big dams (as compared to fairly small dams) for foreign countries because incidents involving smaller dams were not as apt to be reported in technical publications. Notable was the lack of available data from the republics of the former U.S.S.R.

Of the 254 cases in Appendix table A, 165 are earthfill, 23 are rockfill, 19 are earthfill and rockfill, 24 are concrete gravity, 13 are concrete arch, 7 are concrete arch-gravity, 2 are masonry/stone, and 1 is unknown. Interestingly, 120 of the 153 U.S. dams are earthfill, probably because of the large number of relatively small (10-50 m high) irrigation dams that have been built in the Western States. The outstanding examples of this earthfill bias are the States of Colorado, where 52 of the 56 dams are earthfill, and Utah, where all 16 dams are earthfill.

With regard to the primary purposes of the 254 dams, 108 are for irrigation, 56 for hydroelectric power, 48 for water supply, 20 for flood control, 12 for recreation, 5 for debris retention, and 5 for tailings or waste disposal. Within the United States, 85 of the dams are for irrigation, 27 for water supply, 14 for flood control, 14 for hydroelectric power, 11 for recreation, 1 for debris retention, and 1 for fly-ash storage. 
Colorado, the State with the most dams in this study, includes 42 irrigation dams, 7 recreation dams, 6 water-supply dams, and 1 dam for electric power. Of course, many of the dams also have secondary functions in these same categories.

The structural heights of the 254 dams range from the prescribed minimum of $10 \mathrm{~m}$ to a maximum of $170 \mathrm{~m}$. The six highest dams in the study are as follows: Thissavros, Greece (170 m); Upper Gotvand, Iran (170 m); Grand Coulee, United States (168 m); Daniel Palacios, Ecuador (167 m); Thomson, Australia (166 m); and Trinity, United States (164 m). The worldwide distribution of dams by height is as follows: 153 are $10-50 \mathrm{~m}$ high, 62 are $51-100 \mathrm{~m}$ high, 29 are $101-150 \mathrm{~m}$ high, 9 are $151-170 \mathrm{~m}$ high, and 1 dam had no height information. This distribution is to be expected because many more dams exist in the lower part of this range than in the upper part. Also, it is to be expected that smaller dams commonly have not been as carefully sited as the larger dams and, consequently, are more apt to be sited on landslides. The large number of relatively small (10-50 m high) dams on landslides worldwide, however, is more specifically a result of the fact that 115 of the 153 U.S. dams in Appendix table A fall in this category.

It is not easy to categorize the 254 tabulated dams by landslide type because authors of the papers cited often did not indicate what type of landslide was present and because many of the landslides are "complex;" that is, more than one type of slope movement occurred. For each case, I arrived at a "best estimate" of landslide type based on a simplified approximation of the "Varnes landslide classification" (Varnes, 1978; Cruden and Varnes, 1996). In the case of complex landslides, I have noted the primary type of movement at the dam site. In cases where I have not been able to determine the specific type of movement, I have designated the type as "landslide." Nearly all of these "general" cases are located outside the United States because I was able to visit nearly all the U.S. sites to personally evaluate the landslide types. I have broken down the distribution as follows:

- Rock falls (including talus deposits)-20

- Slides in competent or "hard" rocks-60

- Slides in incompetent or "soft" rocks-109

- Earth and debris slides-25

- Rock and debris avalanches-3

- Debris/mud/earth flows, including lahars (volcanic debris or mud flows) - 23

- Cambering and valley bulging-1

- "Landslides" (type unknown)—13

Typical well-indurated, competent, or "hard" rocks include igneous rocks; most metamorphic rocks; hard sedimentary rocks, such as limestones and hard sandstones; and competent volcanic rocks, such as andesite and basalt. Typical poorly indurated or incompetent rocks include shales, soft sandstones, soft volcanic tuffs, and weathered schists. Note that 169 of the 254 cases involve rock slides, in either competent (60 cases) or incompetent (109 cases) rocks. The large number of "soft-rock" slides is largely because of the great number of 10-50 m high dams that have been built on shales and other relatively incompetent sedimentary rocks in the Western United States. In the United States, the number of dams associated with "soft-rock" landslides is 78, as compared to 36 associated with "hard-rock" landslides. Outside the United States, 36 dams have interacted with "hard-rock" slides, versus 31 associated with "soft-rock" landslides. In the United States, numerous dams have been built on very large landslide masses or glide blocks that consist of hard rocks, usually basalts, that have slid intact on underlying softer volcanic or sedimentary materials. The largest of these areas is the Grand Mesa landslide complex in western Colorado, which is the site of dozens of dams and reservoirs, including 19 of the dams in this study.

\section{Selected Case Histories of Dams on Landslides (by Landslide Type)}

This section discusses notable cases in which dams have been built on landslides or landslides have occurred in foundations or abutments either during construction or after completion of the dam. Individual cases are organized by type of landslide.

\section{Rock Fall (Including Talus Deposits)}

Of the 20 cases in this category, only two (Mammoth Pool and Waterbury Dams, both in the United States) are dams that have been sited on large rocks that had fallen to the bottom of steep-walled gorges. The other 18 were cases in which a significant thickness (at least a few meters) of talus on an abutment slope was not removed, or was only partly removed, during construction. In most of these cases, an impervious core zone or trench was dug through the talus, but the mass was left in place under the outer shells of the dam. In several other cases that were reviewed, but not included in Appendix table A, existing talus was removed from the entire footprint of the dam. The main reason for removal of the talus was usually its high permeability. Selected examples of the 20 cases are discussed below.

- Mammoth Pool Dam-Mammoth Pool Dam (fig. 2) on the San Joaquin River in the Sierra Nevada Range of central California, United States, is a 125-m-high earthfill dam, which was completed in 1959 to produce hydroelectric power. As was obvious during early planning for the dam, the canyon originally 


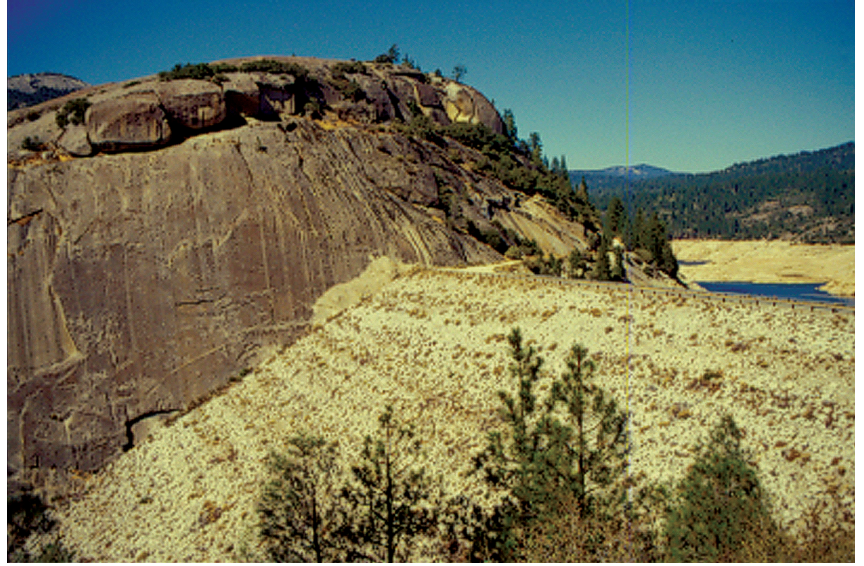

Figure 2. Mammoth Pool Dam, San Joaquin River, California, United States. Note the exfoliation sheets and blocks in the granodiorite that forms the right abutment. Photograph taken in 1998.

was dammed naturally by rock-fall deposits related to exfoliation of the granodiorite that formed the upper canyon walls. Some individual boulders in the bottom of the gorge were as large as $5,000 \mathrm{~m}^{3}$ in size. Professor Karl Terzaghi served as the primary geotechnical consultant for this dam; his main function was to evaluate whether a water-tight dam could be built on these rock-fall deposits, and to decide what types of mitigative measures would control rock fall during construction or future operations of the dam. To ensure safety from rock fall, the remaining sheets of granodiorite on the upper slopes were removed or bolted to the canyon walls (Terzaghi, 1962; Goodman, 1993, p. 242-243). Blocks in or near the location of the cutoff trench at the core of the dam were removed or broken up by means of explosives. The cutoff trench was constructed through the rock-fall detritus to bedrock. Most boulders and rock fragments under the outer shells of the dam were left in place. Mammoth Pool Dam is performing satisfactorily with only minor seepage loss.

- Waterbury Dam-Waterbury Dam is a 57-m-high earthfill dam on the Little River, Vermont, United States. The dam was completed in 1938 but has been subject to foundation seepage since. Unknowingly, the dam was founded on detached rock slabs in a narrow gorge at the base of the dam (fig. 3). As noted by Saber and others (2001), "Detached rock slabs along the right (west) side of the gorge form a roof over a piping tunnel known to have been a piping path in the past, and capable of being a piping path in the future if injected filter materials are destabilized.” A grouting program to prevent seepage through the rock-fall zone was completed in 1985, but, apparently, some seepage continues.

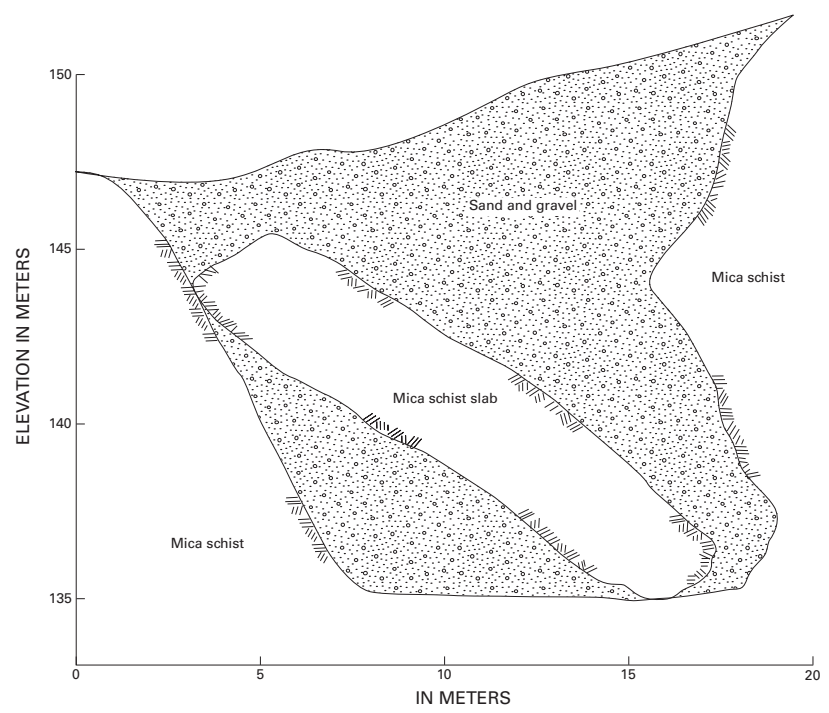

Figure 3. Cross section through the narrow gorge in the foundation of Waterbury Dam, Little River, Vermont, United States. The detached mica schist slab formed a "roof" over a potential piping path in the sand and gravel below. Modified from U.S. Army Corps of Engineers unpublished report (1988).

- Ancipa Dam-Ancipa Dam, a 105-m-high cellular concrete gravity dam on the Troina River of Sicily, Italy, was completed in 1953 to provide hydroelectric power and irrigation water. The dam's right foundation and abutment have a thick talus cover. "At the right bank, the bedrock is reached by a concrete cut-off wall driven through the talus" (ANIDEL, 1961, v. 1, p. 300-306).

- Marmorera Dam-Marmorera (Castilleto) Dam in Graubünden Canton of southeastern Switzerland is a 91-m-high earthfill dam that was completed in 1954 to produce hydroelectric power. The valley wall that forms the left abutment and left end of the dam foundation is a large talus fan (mainly serpentinite fragments) underlain by alluvium and moraine material. Because of the heterogeneity of this foundation and abutment, three separate remedial measures were introduced during the original construction to reduce seepage (Rambert and Gavard, 1961; Schnitter, 1961):

1. An underground curtain wall of concrete was placed to bedrock through the alluvium and morainal deposits in the lower part of the foundation.

2. A cutoff grout curtain was placed through the pervious talus fan that formed the upper foundation and abutment. The grout was a mixture of colloidal clay and cement stabilized by a chemical agent. As would 
be expected, the talus was found to be much more pervious near the surface than at depth.

3. A grout curtain was placed in the bedrock under the core of the dam.

Two successful examples of dams that have been built on talus-covered abutments in the Rocky Mountains of the Western United States are Taylor Park Dam in Colorado and Anderson Ranch Dam in Idaho.

- Taylor Park Dam-Taylor Park Dam is a 63-m-high earthfill dam on the Taylor River in the Rocky Mountains of Colorado, which was completed in 1937 to provide irrigation water for the area. It was recognized before construction that the right abutment of the dam
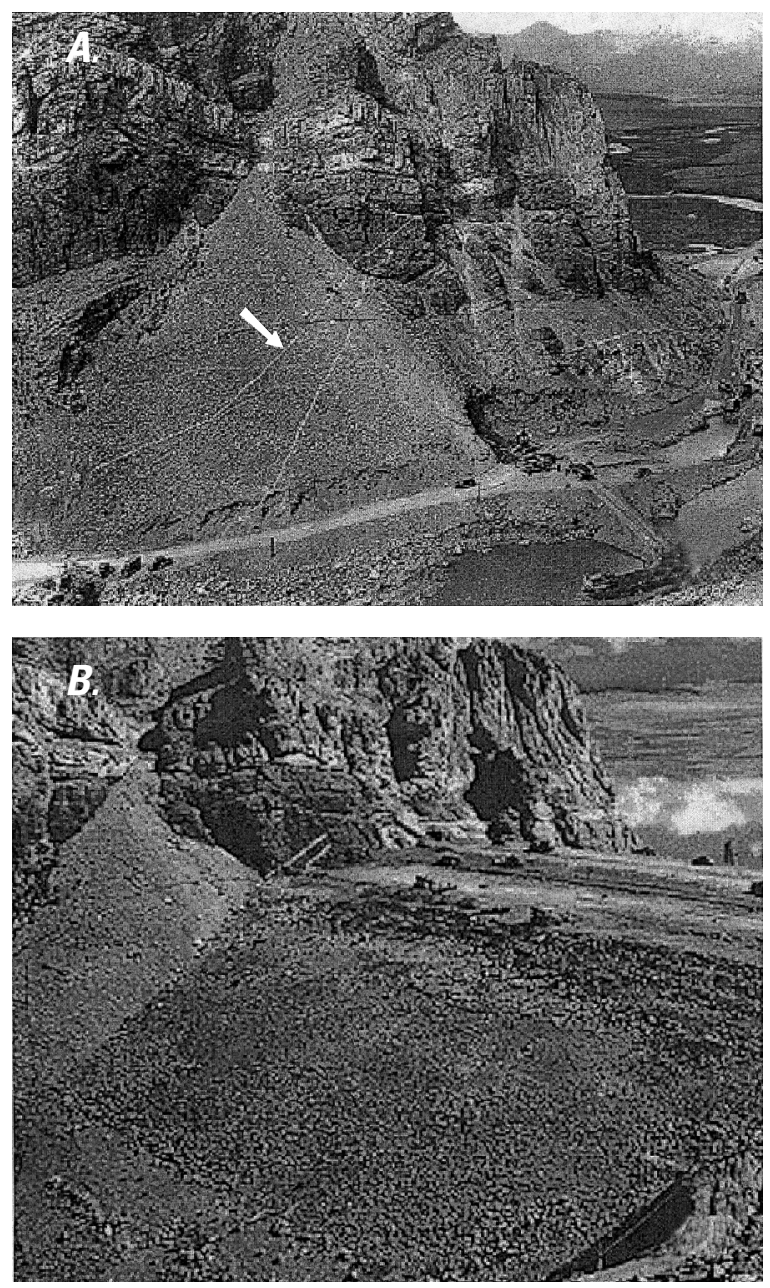

Figure 4. Views before $(A)$ and after $(B)$ construction of Taylor Park Dam, central Colorado, United States. Note the talus deposit that serves as the right abutment of the dam and the chalk line (marked by arrow) in photograph $(A)$, which marks the location of the right end of the future dam on the talus cone. Photographs taken in 1937 by A.A. Whitmore, U.S. Bureau of Reclamation. was covered by a thick talus cone derived from overlying sedimentary rock cliffs (fig. 4). The talus mass consisted predominantly of boulder-to-cobble-size rock fragments with some fine-to-coarse gravel and sand. During construction, the talus was removed from under the center and upstream parts of the dam, but was left in place in the area extending from $\sim 25 \mathrm{~m}$ downstream from the centerline to the downstream toe of the dam. The foundation was prepared by constructing three concrete cutoff walls, one located roughly along the centerline and the other two upstream. The remaining talus in the downstream part of the right abutment poses a very minimal threat of piping; however, thus far, in spite of some seepage, there has been no evidence of piping. The dam has had a long history of satisfactory performance.

- Anderson Ranch Dam-Anderson Ranch Dam on the South Fork Boise River in southern Idaho is a 139-m-high earthfill dam completed by the Federal government in 1971 to provide irrigation water. Before construction, the right abutment was covered by a thick layer of basalt talus, which was removed under zone 1 (the interior, relatively impervious zone) of the dam, partially removed ("engineered") under the upstream shell, and left in place under the downstream shell. Seepage from the right valley wall downstream from the dam apparently passes through this talus. In addition, in recent years a small landslide has occurred into the reservoir at the upstream edge of the "engineered" talus slope.

\section{Slides in Competent Rock}

As noted by numerous authors (for example, Wentworth, 1929), concrete dams, and especially arch dams, require competent rock foundations; while earthfill and rockfill dams can be founded satisfactorily on less-competent materials. However, this study notes 43 concrete dams that were built on pre-existing landslides or had landslides occur during or after construction. As would be expected, most of these concrete dams were built on what was originally thought to be competent rock. A total of 61 of the 254 dams in Appendix table A interact with slides in competent ("hard") rock. Selected examples of these 61 dams are described below.

- Gross Dam-Gross Dam (fig. 5), Colorado, United States, is an example of a concrete-gravity dam that was founded on a pre-existing deep-seated slide in competent rock. Completed in 1955, this 104-m-high municipal water-supply dam is seated on deep-seated "gravity-slip surfaces" in both granite abutments (fig. 6) (Wahlstrom, 1974, p. 78-79). Although these "gravity faults" were closely watched during construction, they pose no hazard to the completed dam, which 
is expected to buttress any possible future movement. Thus, even though the dam is a relatively inflexible concrete structure, this type of slide was primarily a "textbook" case that posed no danger to the dam, and the dam continues to perform well.

- St. Francis Dam-Possibly the best known, and most infamous, of dams that have been built on what was thought to be competent rock, but was actually the toe of a pre-existing landslide, was St. Francis Dam in southern California, United States, a 62-m-high archgravity dam completed in 1926 to supply water to the city of Los Angeles. The presumed stable left abutment of this dam actually was the toe of a large, prehistoric

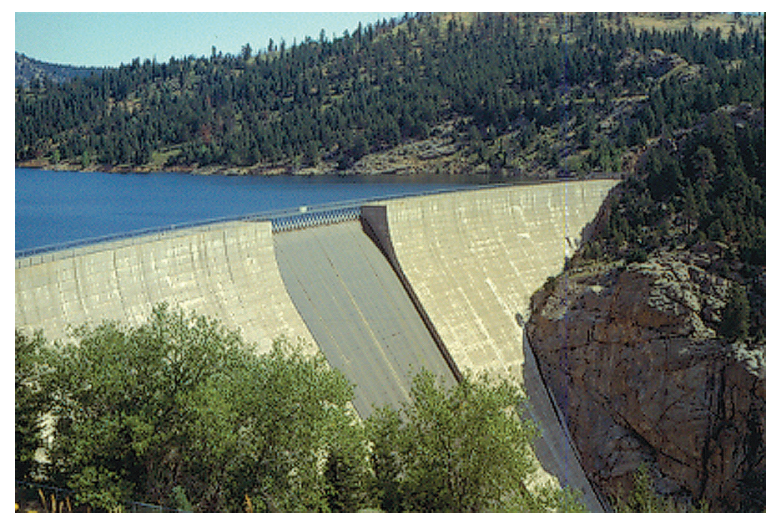

Figure 5. Gross Dam, Colorado, United States, which supplies water to the city of Denver. The cross section in figure 6 shows gravity-slip surfaces in both abutments of the dam. Photograph taken in 2003. landslide in schist bedrock. As the reservoir neared capacity in 1928, the dam suddenly failed, releasing a catastrophic flood that drowned 450 people (Outland, 1977). Preliminary investigations pointed to a fault in the right abutment as the cause of failure. Later, more comprehensive studies (Willis, 1928; Rogers, 1992, 1995, 1997) showed fairly conclusively, however, that failure began as reactivation of the schist slide in the left abutment (figs. 7 and 8). This is the only case noted in this study of a catastrophic dam failure caused by dam construction on a pre-existing landslide. The dam was never rebuilt.

- Beauregard Dam-Another major concrete dam that has experienced reactivation of a rock slide in an abutment is Beauregard Dam, a 132-m-high arch-gravity dam on the Dora di Valgrisenche River in northwestern Italy, which was completed in 1960 (ANIDEL, 1961, v. 1, p. 313-314). The left abutment for this dam is a massive rock slide in mica schist, which before construction overlaid a deep pocket of glaciofluvial sediments (fig. 9) (Desio, 1973, p. 901; Záruba and Mencl, 1982, p. 243-244). During the first filling of the reservoir, the landslide reactivated, attaining a displacement rate of $20 \mathrm{~mm} / \mathrm{month}$. As a remedial measure, some of the sediments were replaced by concrete. In addition, a watertight membrane was placed through the left abutment by cement injection. The dam is performing well.

- Dalešice Dam-Dalešice Dam, a 100-m-high hydroelectric-power rockfill dam on the Jihlava River in the Czech Republic, which was completed in 1979,

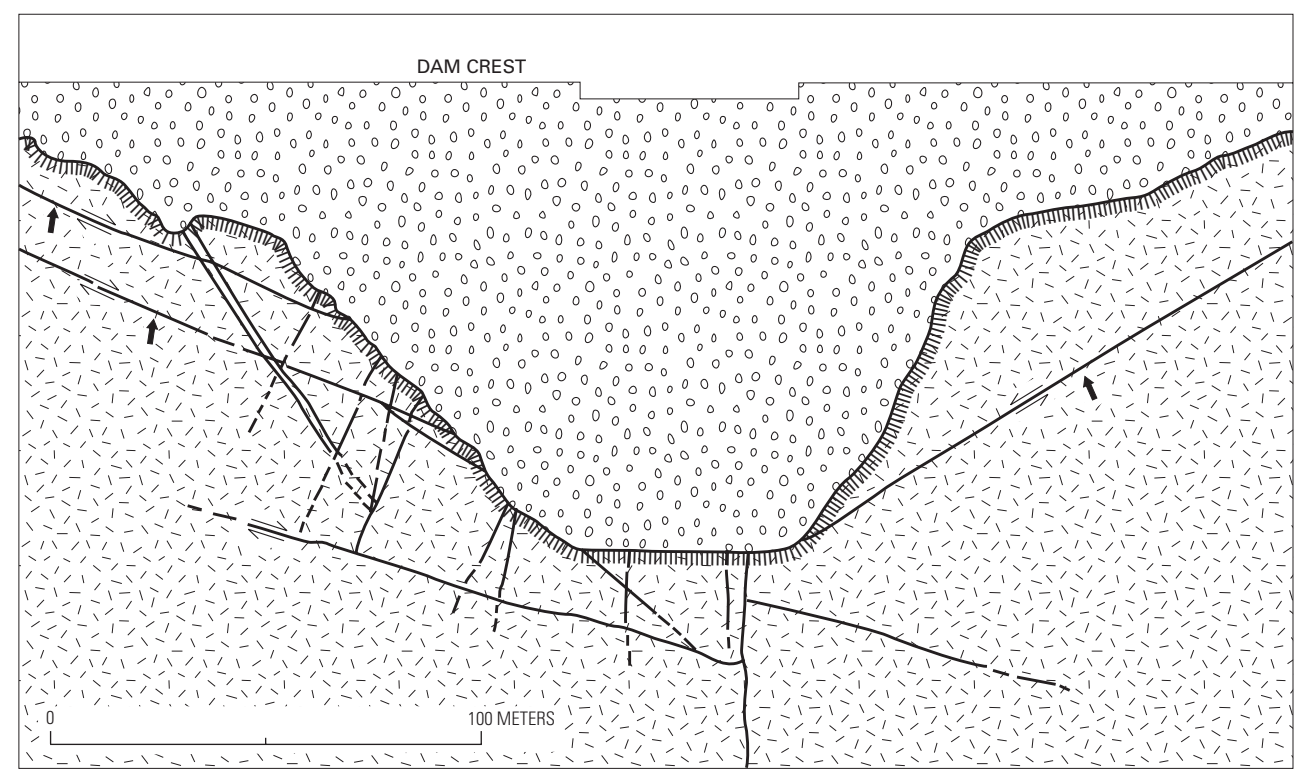

Figure 6. Gravity-slip surfaces (marked by thick arrows) in granitic foundation rocks at Gross Dam, Colorado Front Range, United States. Other faults of tectonic origin are geologically much older than the gravity-slip "faults." Modified from Wahlstrom (1974). 


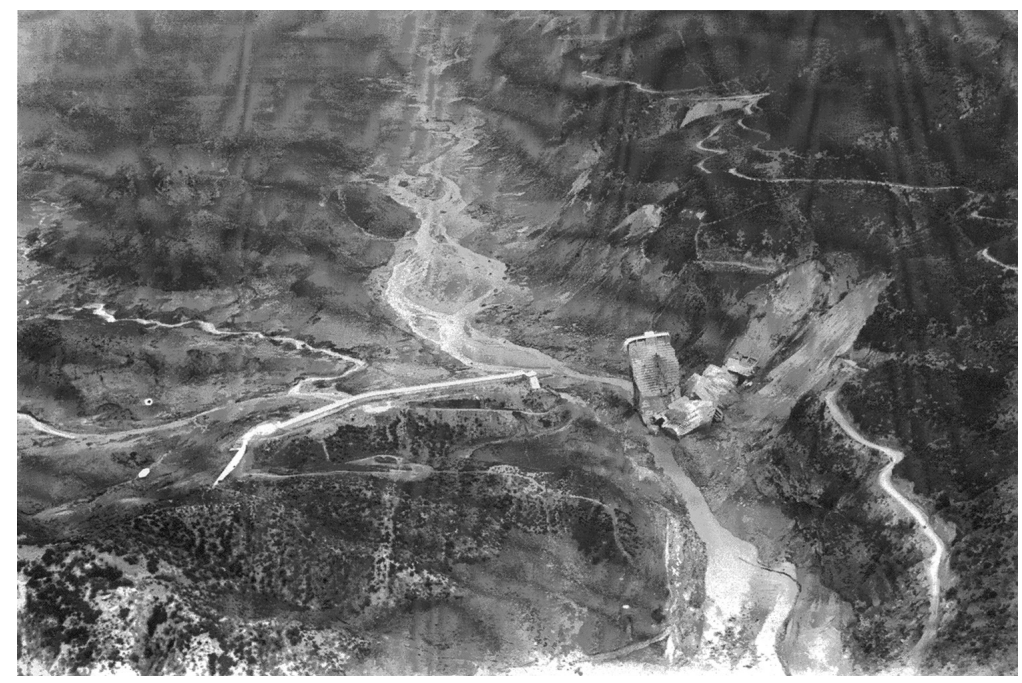

Figure 7. Looking upstream at the remains (center of photograph) of St. Francis Dam, southern California, United States, soon after its 1928 failure, which resulted in a catastrophic flood that killed about 450 people. The failure began in the toe of a large prehistoric landslide that formed the left abutment (right side of photograph); note fresh landslide scarps. Photograph taken in 1928, courtesy of Department of Geography, University of California at Los Angeles.

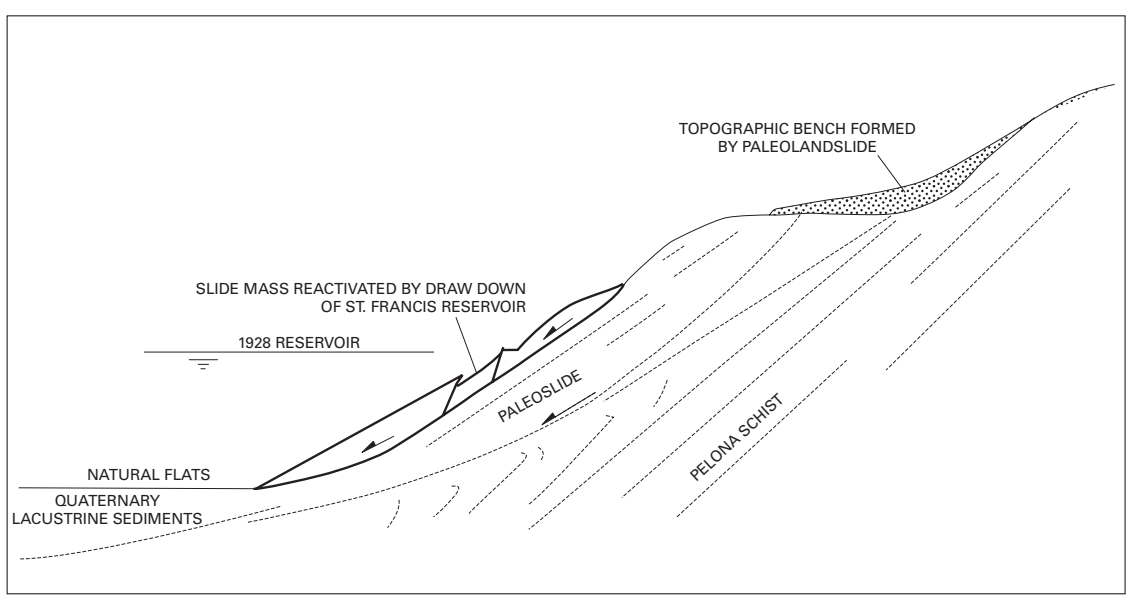

Figure 8. Cross section through the 1928 left-abutment landslide at St. Francis Dam, California, United States. Modified from Rogers (1995).

Figure 9. Cross section through the preexisting rock slide that forms the left abutment of Beauregard Dam, northwestern Italy. Modified from Desio (1973, p. 901)

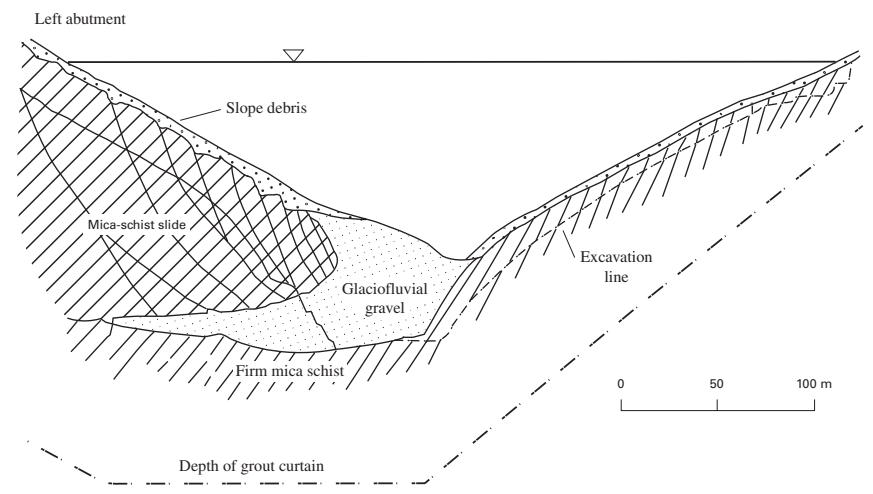


was founded on supposedly stable amphibolite and granulite. However, during excavation for the right abutment of the dam, failure occurred in schistose mylonite along a fault contact between the amphibolite and the granulite. The failure resulted in sudden movement of a 150,000 $\mathrm{m}^{3}$ block of amphibolite along the mylonite zone (Mencl, 1977; Záruba and Mencl, 1982, p. 245-246) (fig. 10). As remedial measures, a temporary stabilizing berm was built at the toe of the slope and material was removed at the head of the slide. Subsequently, the slope was further stabilized by making horizontal benches from which anchors were installed into the firm granulite (Hobst and Zajíc, 1983, p. 399-401).

- Tablachaca Dam-Another well-known example of a concrete dam built on a pre-existing slide in competent rock is Peru's Tablachaca Dam (figs. 11 and 12), an 80-m-high concrete arch-gravity dam on the Mantaro River, a tributary of the Amazon River. This dam was placed in service in 1972 to produce about one third of Peru's electric power. During the late 1970s, it was noted that part of an ancient rock slide in phyllite, which formed the right abutment of the dam, had reactivated (probably because of the reservoir) and was moving slowly toward the dam (fig. 13)
(Novosad, 1979; Novosad and others, 1979). A system of remedial measures, which included an earth berm at the toe of the slope (the toe of the berm is underwater), prestressed rock anchors, and drainage adits, were installed during the 1980s (Morales Arnao and others, 1984; Repetto, 1985; de la Torre and others, 1997) at an estimated cost of U.S. \$40 million (1985 dollars). Since then, the dam has generally performed well; however, recently there has been renewed creep in the right abutment (Garga and de la Torre, 2004).

- Lake Harriet Dam-Another interesting concrete-arch dam case is that of Lake Harriet Dam, a 21-m-high dam (fig. 14) that was completed in 1923 to produce electric power for western Oregon, United States. The left abutment of this dam was thought to be stable basalt. However, this basalt abutment is part of the reactivated toe of a $50-\mathrm{km}^{2}$ landslide mass. During the early 1980s, cracks were noted in the dam due to compression from the left abutment. The problem was solved in 1985 by using the tremie process (underwater pumping through a pipe) to place a soil-bentonite "membrane" against the upstream face of the dam, and by constructing rockfill buttresses against both faces of the dam (Schroeder and others, 1988). Although the dam is currently performing well, the compressive

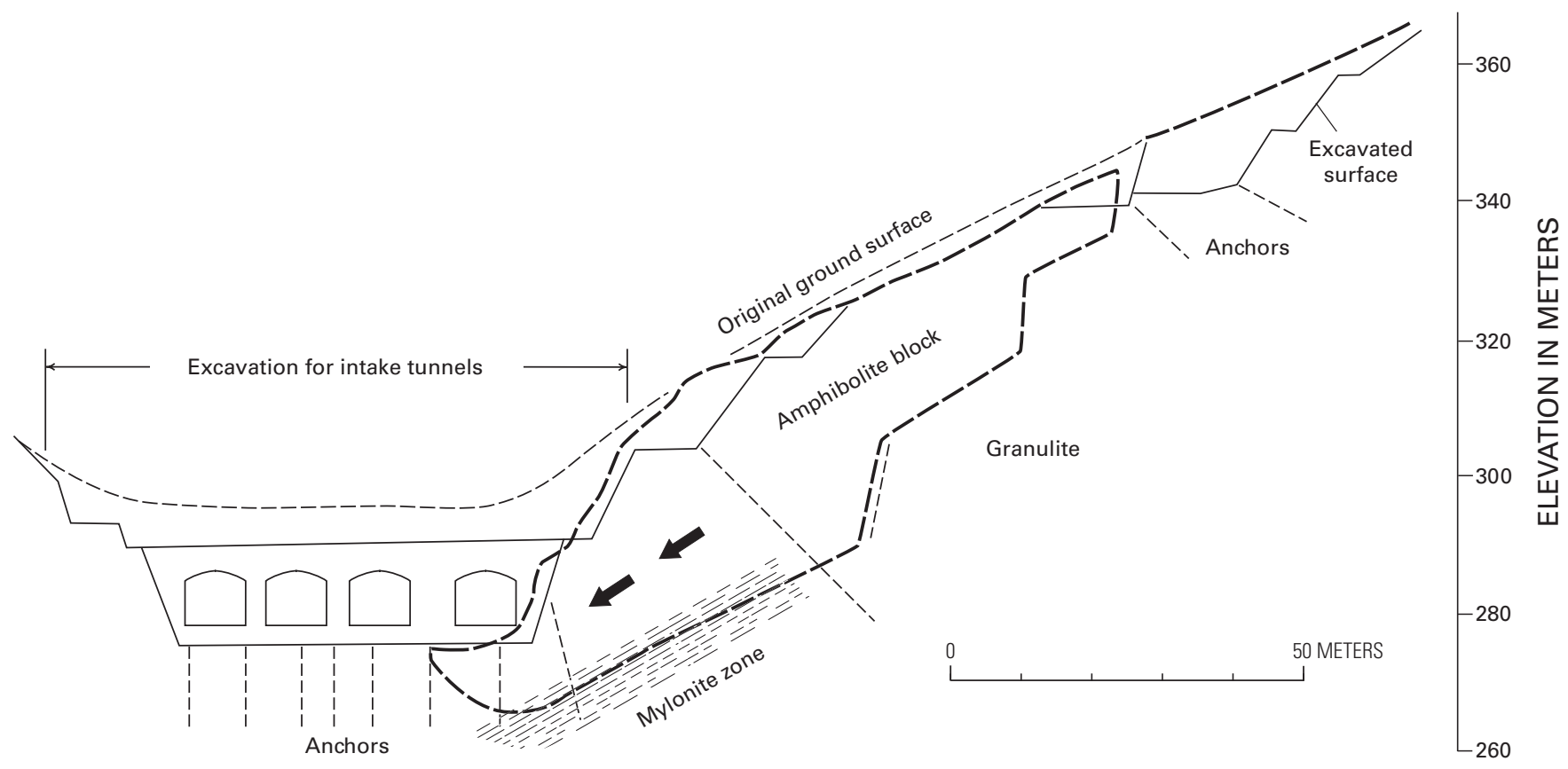

Figure 10. Simplified cross-valley cross section through Dalešice Dam, Jihlava River, Czech Republic. Construction caused reactivation of a rock slide of the amphibolite in the right abutment. This cross section shows locations of remedial excavations and rock anchors. Modified from Záruba and Mencl (1982, p. 246). 


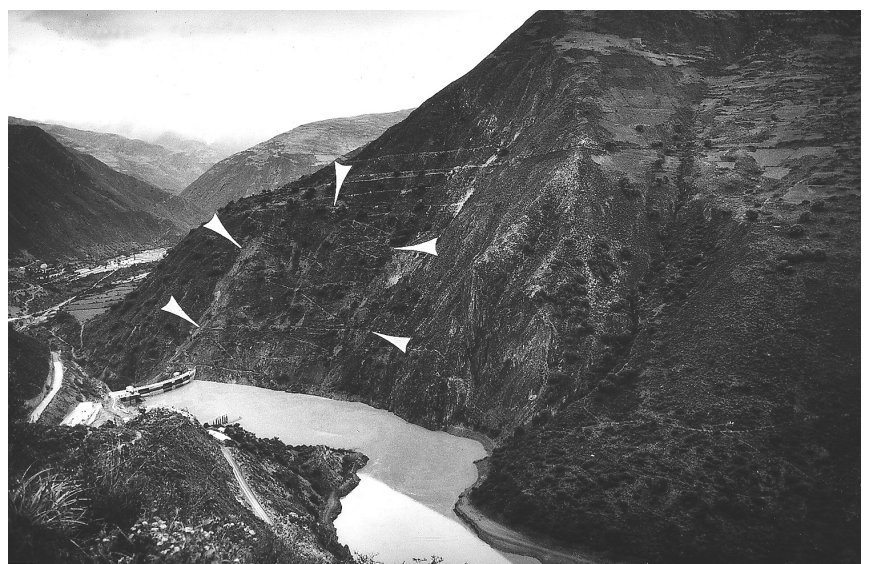

Figure 11. Oblique view of Tablachaca Dam, Peru. The preexisting rock slide in the right abutment is outlined by arrows. This slide was reactivated in the 1970s, probably because of infiltration from the reservoir. Photograph taken in 1982.

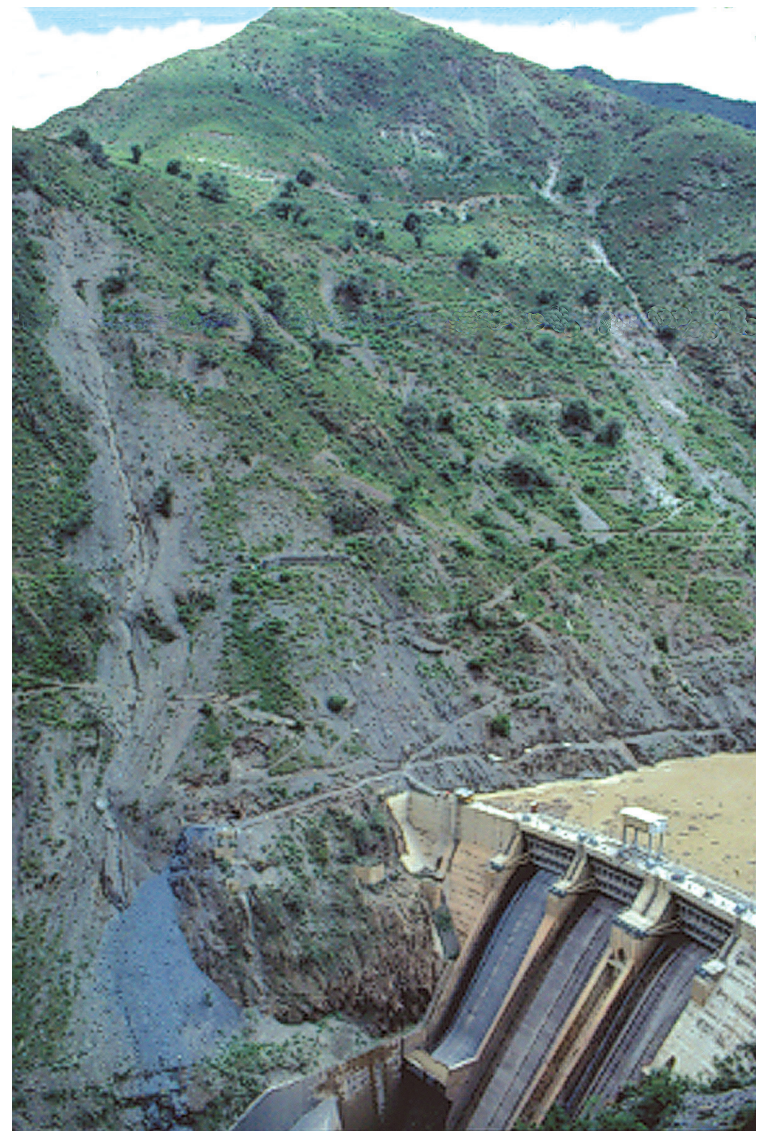

Figure 12. Looking upstream at the right-abutment landslide at Tablachaca Dam, Peru. Photograph taken in 1982.

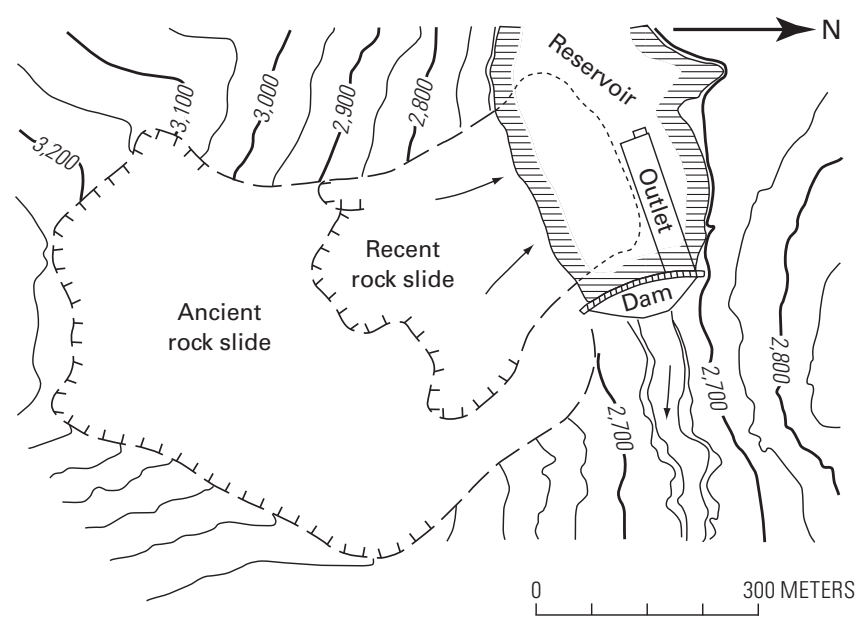

Figure 13. Map of rock slide at the right abutment of Tablachaca Dam, Peru. Shown is the recent, active slide that is a reactivation of the toe of a larger, ancient rock slide. Modified from Novosad (1979).

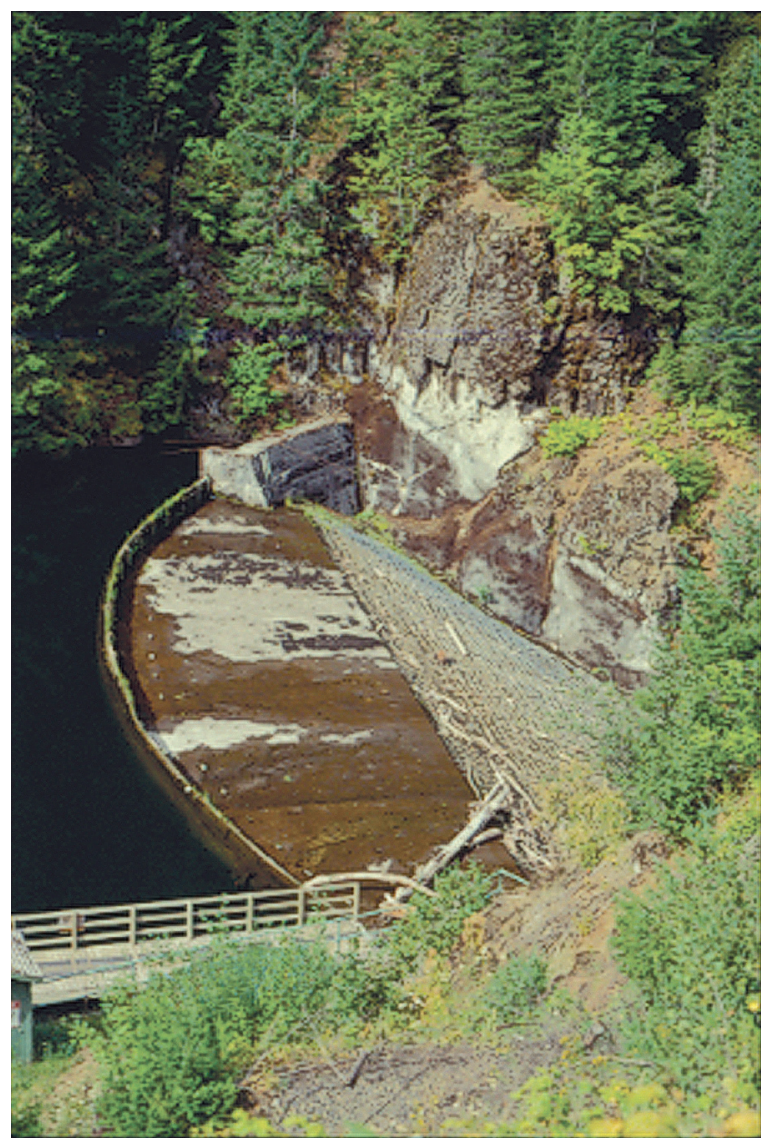

Figure 14. Lake Harriet Dam, Cascade Range, Oregon, United States. The basalt that forms the left abutment of this dam is part of the reactivated toe of a $50-\mathrm{km}^{2}$ landslide mass. Photograph taken in 1999. 
force of the landslide continues to act against the dam through the basalt abutment.

- Bonneville Dam-Another well-known example of a dam on a major rock slide is Bonneville Dam, a 60-m-high concrete gravity dam in the Columbia River Gorge of Washington and Oregon, United States. It was completed in 1937 for purposes of hydroelectric power production, navigation, and recreation. The Columbia River Gorge includes several large Holocene landslides in basalt underlain by less-competent volcanics (fig. 15) (Palmer, 1977). The right (Washington) abutment of this dam is part of the toe of the Bonneville landslide (figs. 16 and 17), the youngest element of the huge Cascade landslide complex (figs. 15 and 17) (Sager, 1989; Keech and Sanford, 1998; Schuster and Pringle, 2002). Although there have been minor surficial movements of the Bonneville landslide, its mass is so large and well-seated that the dam abutment and foundation are stable, and the dam continues to perform well.
- Durlassboden Dam-A European example is Durlassboden Dam, an 83-m-high structure in Austria, which was built on a large rock slide. The right abutment of this hydropower dam is on a large block of graphitic schists and quartzites that had slid down the right valley wall and sunk into valley deposits of glaciofluvial sands and gravels and lacustrine silts (Mignon, 1968; Záruba, 1974; Rienössl and Schnelle, 1976) (fig. 18). The abutment and foundation were subsequently sealed by a grout curtain that extends into silts about $50 \mathrm{~m}$ beneath the valley floor.

- Platoro Dam-Another example in the Western United States is Platoro Dam, a rockfill/earthfill dam on the Conejos River in the San Juan Range of southwestern Colorado, which was completed in 1951 to provide irrigation water for the area. The left end of this 50-m-high dam rests on a massive andesite slump block (length $>1 \mathrm{~km}$ ). Because of the large, wellseated mass of the block, there have been no stability or seepage problems, and the dam continues to perform well.

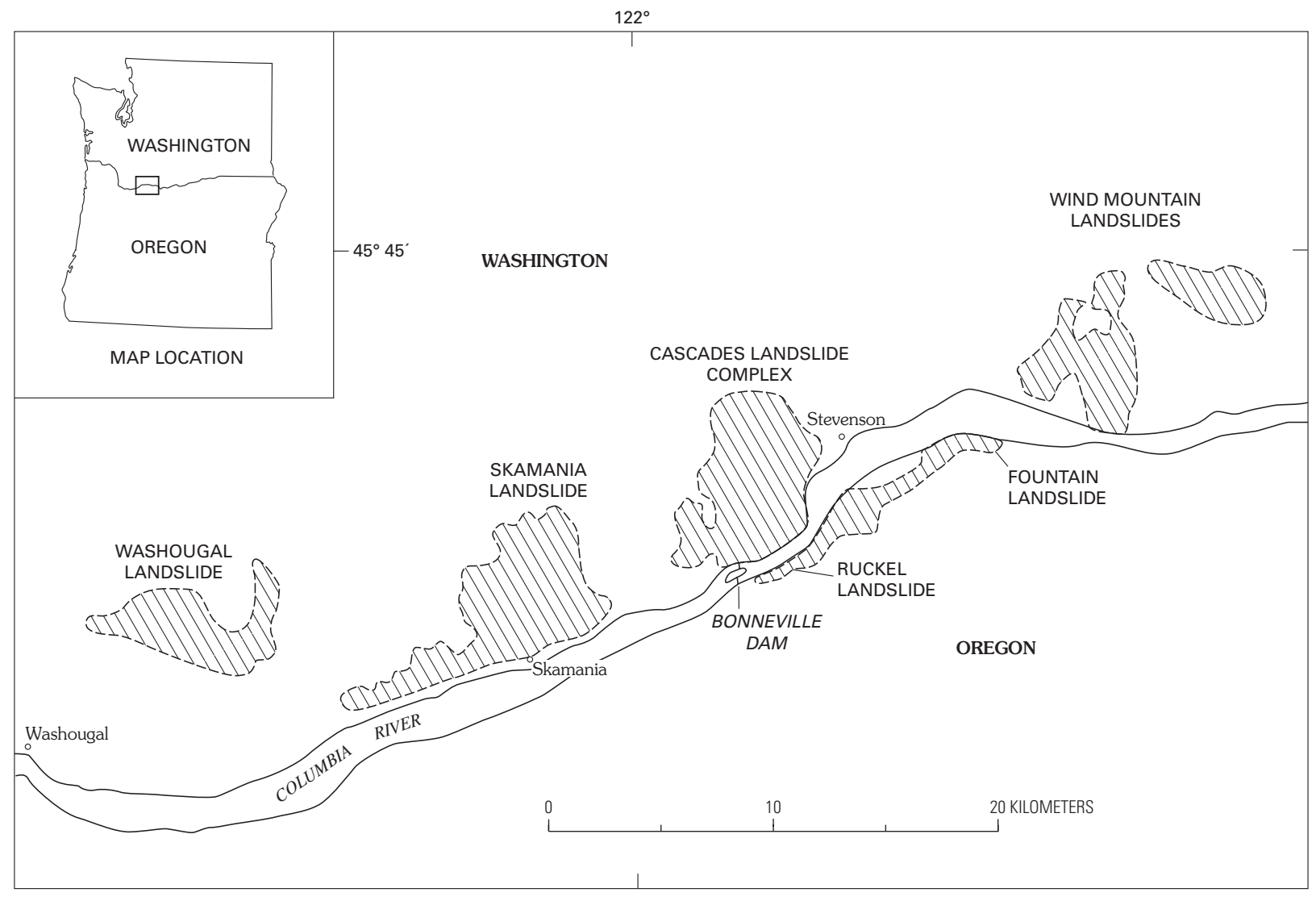

Figure 15. Major Holocene landslide deposits in the Columbia River Gorge, Washington and Oregon, United States, including the Cascades landslide complex, the youngest element of which is the Bonneville landslide (figs. 16 and 17). Note the location of Bonneville Dam. Modified from Palmer (1977). 


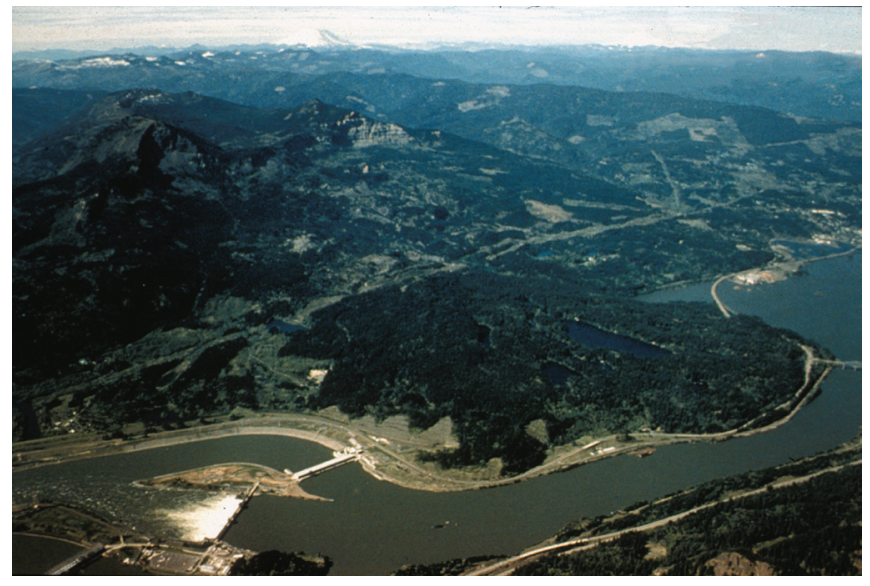

Figure 16. Oblique aerial view of Bonneville Dam in the Columbia River Gorge, Washington and Oregon, United States. The right (Washington) abutment is the toe of the huge Bonneville landslide, which is the most recently active part of the Cascades landslide complex. Photograph by Derek Cornforth, Landslide Technology, Portland, Oregon.

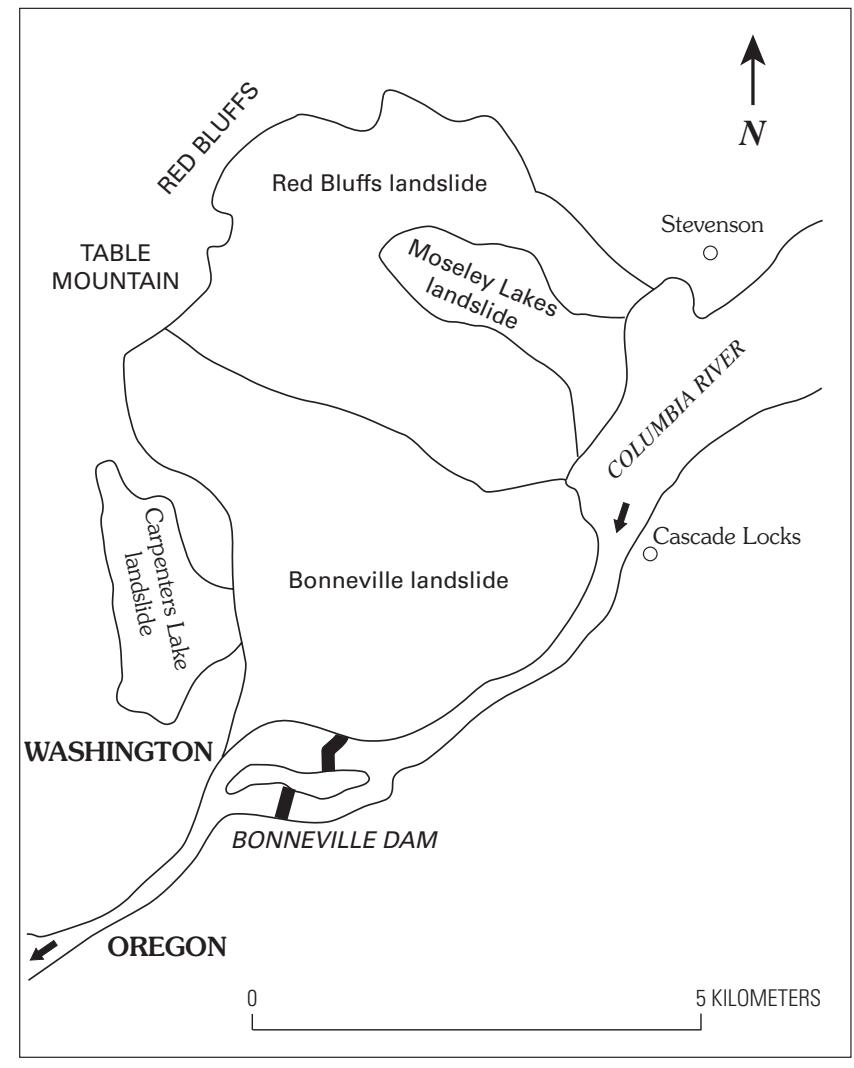

Figure 17. Map of the Cascades landslide complex and its components, which include the Bonneville landslide. Note the location of Bonneville Dam. Modified from Wise (1961).

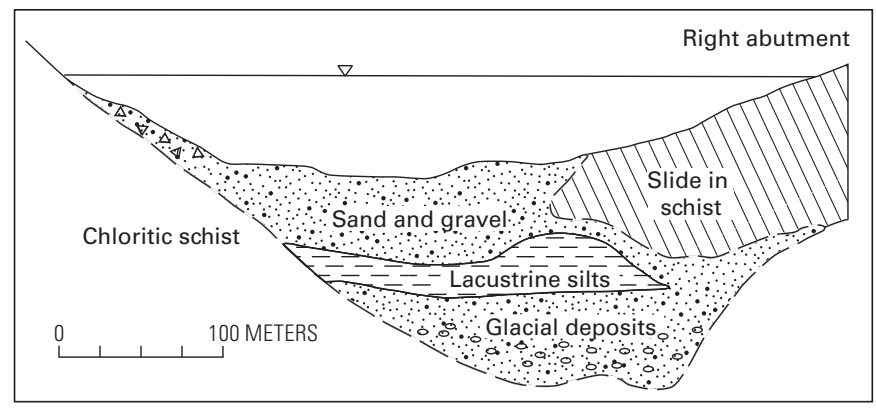

Figure 18. Simplified cross section through the rock slide in schist that forms the right abutment of Durlassboden Dam, Austria. Modified from Záruba and Mencl (1982, p. 243).

Occasionally, movement along pre-existing joints or faults in seemingly competent rock abutments is reactivated by dam construction. In many cases, any movement is halted by the buttressing effect of the dam itself. Movement of masses of competent rock along joints and fractures in this manner does not traditionally characterize the slipped rock masses as landslides. However, such movement of competent rock masses in this manner may create problems for dams similar to those caused by landslides. Two cases of dams that interact with this type of movement of rock masses are included in Appendix table $\mathrm{A}$ and are discussed below.

- Meishan Dam-An example is Meishan Dam, an 88-m-high concrete multiple-arch dam on the Shihe River, Anhui Province, China. This dam, which was completed in 1956 for purposes of flood control, irrigation, and hydropower, was founded on jointed granite, and, in 1962, movement occurred along joints in the right abutment (Qi, 1986; Chinese National Committee on Large Dams, 1987, p. 134-138). Apparently, these joints had exhibited some movement before construction. Remedial measures included installation of a grout curtain, an impervious membrane upstream of the abutment, anchors, and berms that served as buttresses.

- Tooma Dam-An Australian example is Tooma Dam, a 67-m-high, earthfill/rockfill dam constructed on the Tooma River of southeastern Australia to produce hydroelectric power. After completion of the dam in 1961, sliding was noted along joints in both abutments (Hunter, 1982; Fell and others, 1992). Remedial measures included rockfill buttresses, "dental" work in open joints (filling voids with cement grout or concrete), addition of a downstream grout curtain, and adding to the impervious zone of the embankment. 


\section{Slides in Incompetent Rock}

One hundred and nine of the dams in Appendix table A were built on landslides in poorly indurated, relatively incompetent rocks. Most of the slides in this category have occurred in soft sedimentary rocks, mainly shales, mudstones, siltstones, and poorly indurated sandstones, and in weathered schists and weak volcanics. Embankment dams have commonly been constructed at sites where incompetent materials form dam foundations or abutments.

- Slezska Harta Dam-In the Czech Republic, Nechranice, Slezska Harta, Terlicko, and Zermanice Dams have all encountered problems with "soft rock" abutments. Especially well known are the problems in the shale left abutment of Slezska Harta Dam, a 65-m-high rockfill structure on the Moravice River, which was completed in 1997 for purposes of water supply and flood control. During construction of this dam, movement occurred in shale slide deposits that made up the left abutment (Novosad, 1990; Torner and Novosad, 1991). The stability problem was mitigated by excavation of slide material from the upper left slope, construction of a berm at the toe of the slope, and installation of surface and underground drains (Novosad and Novosad, 1993).

- Fruitgrowers Dam-An interesting example of a dam in the Western United States that was built on soft rocks is 17-m-high Fruitgrowers Dam, an earthfill dam built to provide irrigation water in western Colorado. The original Fruitgrowers Dam (11 m high) was constructed in 1898, but failed in 1937 due to "saturation and slipping" in the embankment at the spillway, which caused considerable flood damage to the small town of Austin, the Denver \& Rio Grande Western Railroad, and a State highway (Engineering News-Record, 1937). The current dam was built in 1939, and its left abutment is on a large landslide in shale (fig. 19). Slow movement began in this shale mass in the late 1990s. This abutment is currently being closely monitored to determine if remedial measures will be needed, but otherwise the dam is performing well.

Soft sedimentary rocks form the abutments or foundations of several major dams in the Great Plains of central North America. In a few of these cases, pre-existing slides in soft sedimentary rocks of the valley walls have affected design and construction of major Canadian and U.S. dams. Two outstanding examples follow.

- Gardiner Dam-Especially well known in Canada is the case of Gardiner Dam, an earthfill dam on the South Saskatchewan River in the central province of Saskatchewan. This 69-m-high dam was completed in 1968 for purposes of irrigation, water supply, and

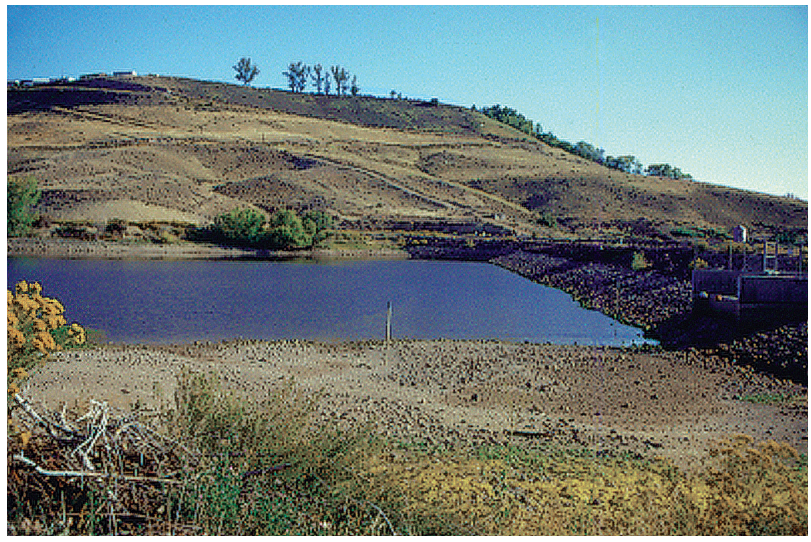

Figure 19. Fruitgrowers Dam, an irrigation dam in western Colorado, United States, showing apparent landslide topography in shale of the left abutment. Photograph taken in 1999.

production of hydroelectric power. The shale left abutment of the dam included a large prehistoric slide (Ringheim, 1964; Jaspar and Peters, 1979). Local failure occurred in this abutment during construction, which led to excavation of much of the unstable shale under the central zone of the dam. To increase the stability of the abutment, the slopes of the remaining landslide deposit were flattened, and extensive berms were added as buttresses. The dam is performing satisfactorily.

- Oahe Dam-In the United States, several large dams on the upper Missouri River have been built on soft sedimentary rocks. One of these is Oahe Dam, a 75-m-high earthfill dam in South Dakota, which was completed in 1966. During construction, problems were encountered that were caused by pre-existing shale slides in the right abutment, and construction triggered a slide in the left abutment (Engineering Division, 1958; Knight, 1963). After the left-abutment slide occurred, 5.0 million $\mathrm{m}^{3}$ of slide material was removed; of this, 3.5 million $\mathrm{m}^{3}$ was placed at the toe of the slope as a berm that acts as a buttress. Part of a small slide remains in the right abutment. Both abutments are now completely stable because of the buttressing effect of the dam itself, and the dam continues to perform well.

\section{Massive Rock Slides and Glide Blocks}

In the Western United States, numerous dams have been built on massive landslides and glide blocks; these are cases in which entire dams and reservoirs lie on the large landslide masses. The best known of these cases are dams on landslides adjoining the Grand Mesa in western Colorado, on huge 
landslide masses in the mountains of north-central Colorado, and on the Malaga landslide in central Washington State.

- Grand Mesa landslide area-Rising to an elevation of 3,300 $\mathrm{m}$, the Grand Mesa is an $\sim 130-\mathrm{km}^{2}$ plateau remnant in western Colorado that is capped by continuous undisturbed upper Tertiary basalt flows that slope gently to the west. The basalt flows are underlain by a sequence of claystone, conglomerate, and sandstone, which overlies the Tertiary Green River Formation. Where these relatively weaker sedimentary rocks have failed, they have formed steep basalt cliffs, 30-150 m high, which surround the upland surface of the Grand Mesa (Yeend, 1969, 1973). A very irregular surface, produced by huge slumps and modified by glaciation, extends outward from the base of the basalt cliffs (Baum and Odum, 1996, 2003). Numerous lakes formed on this irregular surface as a result of the slumping and subsequent glaciation. The surface levels of many of these natural lakes have been raised by the addition of man-made dams. East of today's Grand Mesa, the landslide bench is extensive. Overall, this huge area of slump blocks extends about $70 \mathrm{~km}$ from east to west and $20 \mathrm{~km}$ from north to south, most of it lying to the east of the basalt remnant of the Grand Mesa (fig. 20).

As became obvious early in the 20th century, the irregular surface topography of this large landslide bench was well-suited for the easy impoundment of snowmelt by dams and reservoirs. Thus, many dams and reservoirs were built on these landslides and intermingled glacial deposits. Appendix table A lists 19 irrigation, water supply, and/or recreation dams that are founded on the Grand Mesa landslide bench, ranging in structural height from 10-26 m (there are no larger dams in the Grand Mesa area). Noted in Appendix table A as being on this landslide bench or on rockfall deposits from Grand Mesa cliffs are the following Colorado dams: Atkinson, Big Beaver, Bonham, Cedar Mesa, Eggleston, Goodenough \#2, Granby \#12, Hogchute, Kehmeier, Kennicott Slough, Kiser Slough, Knox, McKoon, Monument \#1, Overland \#1, Park, Vela, Ward Creek, and Young's Creek Nos. 1 and 2. Several of these dams have had foundation or abutment seepage problems, often requiring repairs, but none has manifested stability problems or pose downstream hazards.

- Mountains of north-central Colorado-North-central Colorado includes several subranges of the Rocky Mountains, in which large rock slides consisting of resistant rocks (usually volcanics) overlying softer rocks (usually shales, siltstones, and soft sandstones) are common. These rock slides often occurred as massive landslides from the valley walls upon retreat of late Pleistocene valley glaciers. They have formed

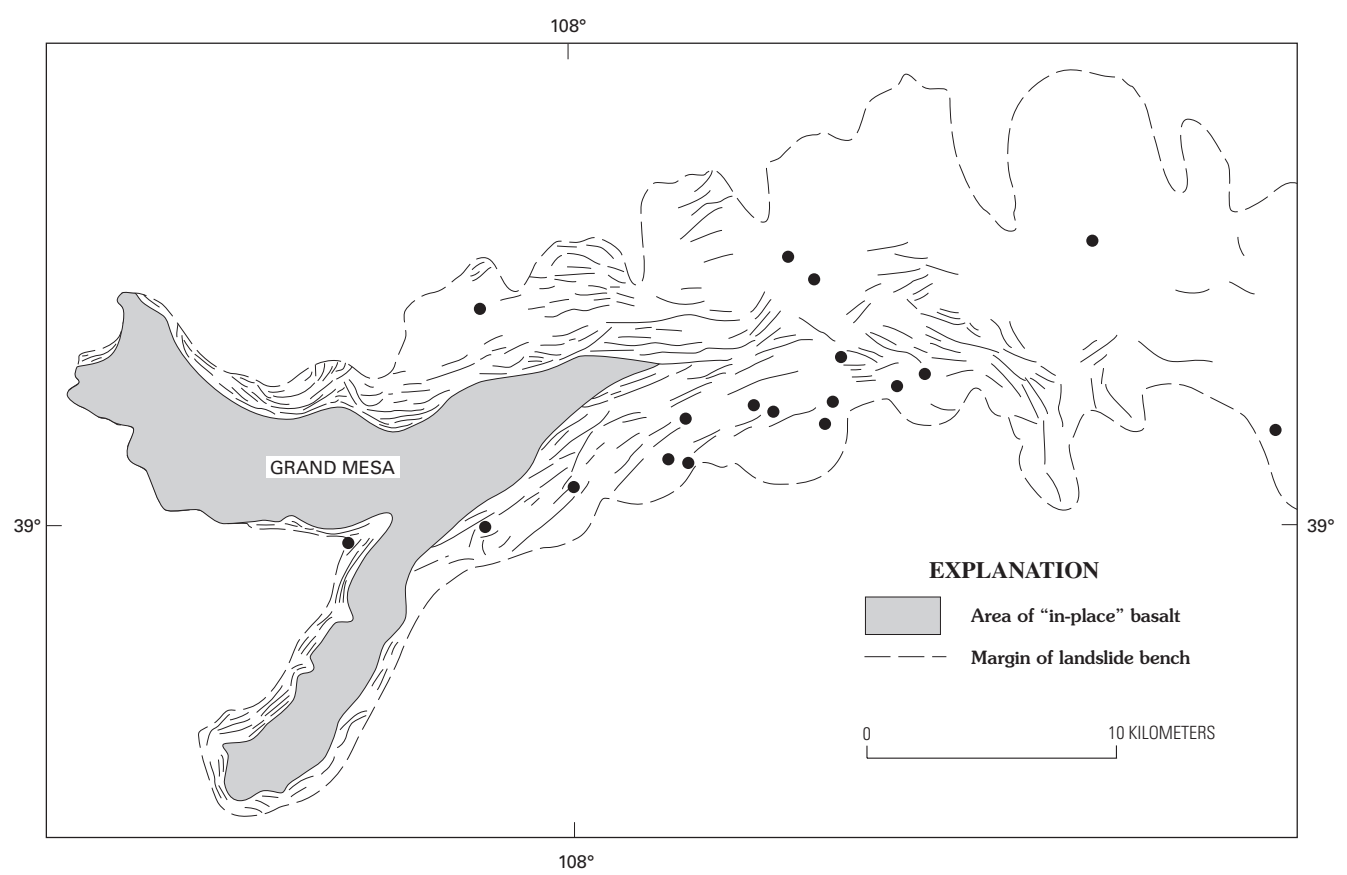

Figure 20. Locations of 18 dams (solid circles) on landslide bench and slump-block landslides derived from the basalt plateau of the Grand Mesa, western Colorado, United States. One other dam (Overland Dam) is located on these landslide deposits, less than $2 \mathrm{~km}$ east of the eastern border of this figure. The landslide map has been modified from Yeend (1969). 
constrictions in high mountain valleys, resulting in seemingly opportune sites for the location of dams. Examples of these in Appendix table A include Stillwater \#1, Upper Stillwater, Yamcolo, Poose Creek, and Sheriff Dams, which are irrigation and recreation dams located in valleys that drain from the northeast slopes of the Flattop Mountains that consist of Tertiary basalts overlying shales and sandstones. A similar example from Appendix table A, Joe Wright Dam, is a large water-supply dam on eastward-flowing Joe Wright Creek in the Colorado Front Range. These dams are all performing well.

Three other dams and their reservoirs in north-central Colorado, which are included in Appendix table A, are located entirely on large glide blocks in soft rocks. Jones \#2 Dam, a 12-m-high earthfill dam built in 1887, which impounds the main water-supply reservoir for the town of Kremmling, lies on a massive prehistoric $16-\mathrm{km}^{2}$ glide block in shales and sandstones of the Niobrara and Dakota Formations (Barclay, 1968, p. 157; Izett and Barclay, 1973; Madole, 1991a). D.D.\&E. Wise (Aldrich Lake) Dam, a 12-m-high earthfill irrigation dam, lies on the eastern edge of a massive $16-\mathrm{km}^{2}$ landslide in Mancos Shale (Madole, 1989). Lower Cogdill Dam is a 12-m-high earthfill irrigation dam that was constructed in 1956. The dam and reservoir lie entirely on an $18-\mathrm{km}^{2}$ glide block overlying Lewis Shale and Mesaverde Group sandstones and shales on the west slope of the Elkhead Mountains in northwestern Colorado (Madole, 1982). Minor seepage issues from toe drains at Jones \#2 Dam. Lower Cogdill and D.D.\&E. Wise Dams have shown no distress related to their landslide foundations and abutments, and overall all three dams continue to perform satisfactorily.

Matheson Dam, an 18-m-high irrigation dam, was built in 1951 on the northeast edge of an $18-\mathrm{km}^{2}$ landslide mass (Tertiary volcanics overlying Morrison Formation shales and sandstones) in the Rabbit Ears Range northeast of Kremmling (Madole, 1991a). There has been some seepage through the landslide right abutment of this dam, probably related to the landslide materials; otherwise the dam is performing well.

- Malaga landslide area-The Malaga landslide, a large glide block on the west side of the Columbia River near Wenatchee, Washington, United States, consists of basalt that overlies softer volcanics and sedimentary rocks. Its irregular surface has served as a site for several small dams. Qualifying as large dams are Stemilt Main Dam (height, 20 m) and Upper Wheeler Dam (height, $20 \mathrm{~m}$ ), two irrigation dams that are founded entirely on this large glide block. The Stemilt Main Reservoir leaked considerably through the landslide material until an impervious geosynthetic membrane was successfully emplaced in 1986. Minor leakage at the left abutment was later remedied by installation of drains. Minor leakage at the left abutment of Upper Wheeler Dam also has been controlled by installation of drains.

\section{Earth and Debris Slides}

Twenty-four of the 254 dams tabulated in this study have earth- or debris-slide material in the foundation or abutments. With two important exceptions, these were embankment dams. The exceptions are two concrete dams: Grand Coulee Dam, United States, and Vodo Dam, Italy. Some examples of the 24 dams in Appendix table A are described below.

- Grand Coulee Dam-Grand Coulee Dam (fig. 21) is a 168-m-high concrete-gravity structure on the Columbia River in Washington State, United States. This dam, at one time the largest (in volume) concrete dam in the world (its volume recently has been exceeded by that of China's Three Gorges Dam), was completed in 1942 to provide irrigation water, hydroelectric power, and flood control for the U.S. Pacific Northwest. Granite is the main foundation material for Grand Coulee Dam, but the right abutment included unstable glacial varved clays. Preparation of the right abutment reactivated movement of these clays (Irwin, 1938). The clays were stabilized by flattening the abutment slope, construction of a timber-crib retaining wall, and freezing the soil upslope from the wall by installation of a system of pipes that carried brine at below-freezing temperatures (Gordon, 1937). The slide area was then buttressed by the right end of the dam. This abutment

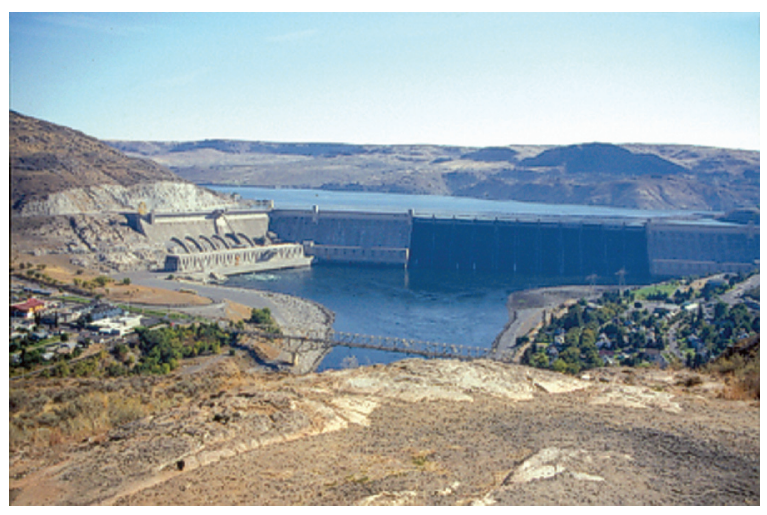

Figure 21. Grand Coulee Dam, eastern Washington State, United States. In 1969, the original landslideprone glacial-soil right abutment was removed to make room for the second powerplant at the right end of the dam (left edge of photo). Photograph taken in 1999.

was subsequently removed in 1967-81 when the dam was lengthened to accommodate the third powerplant. Thus, the dam no longer abuts a landslide and is performing well.

- Vodo Dam-Vodo Dam on the Boite River in the northern Italian Province of Veneto is a 42-m-high 
concrete domed-arch dam that was built in 1960 to provide hydroelectric power. Its left abutment has been described as consisting of "morainic materials and alluvial landslides" (ANIDEL, 1961, v. 1, p. 320). To prevent movement of these materials during construction, a diaphragm, consisting of overlapping piles in reinforced concrete, was placed in the abutment through a bentonitic-slurry trench, and there have been no problems since.

- Lake Sherburne Dam-Two examples of earthfill dams that have been built on earth slides are located in the State of Montana, United States; both were built on unstable glacial deposits. The better-known of these is Lake Sherburne Dam, a 33-m-high earthfill dam on Swiftcurrent Creek at the northeastern edge of Glacier National Park. This dam was completed in 1921 to provide irrigation water for eastern Montana. Apparently, it was known at the time that both valley walls consisted of massive landslides derived mainly from glacial deposits (Carrara, 1990; Whipple, 1992). Although the right abutment appears to be relatively stable, the left abutment is surrounded by a large unstable slide. The original foundation preparation included installation of three continuous cutoff trenches into stable till across the valley floor (Lowe, 1988). Prior to 1960 , movement of the left abutment destroyed the original spillway, which was then moved to the right end of the dam. The left abutment remains unstable; its movement is being monitored regularly.
- Hyalite Dam-Hyalite Dam in southwestern Montana is a 38-m-high earthfill dam that was completed in 1951 to provide water for irrigation and water supply. The left abutment of this dam consists of mixed landslide and glacial deposits made up of clay, silt, sand, poorly sorted gravel, rock fragments, conglomerate, and boulders. There have been no problems with stability; however, seepage through this abutment material has been a continuing problem. Thus, during the 1990s, a compacted earth liner was placed at the left end of the dam to reduce the seepage. The dam is now performing well.

\section{Rock and Debris Avalanches}

Only three of the 254 dams in Appendix table A have been in contact with rock or debris avalanches. These three are Parangana, Cheakamus, and Smith and Morehouse Dams.

- Parangana Dam-Parangana Dam is a 53-m-high rockfill structure on the Mersey River on the island of Tasmania, southeastern Australia. The dam was completed in 1968 to produce electric power for the island. Debris-avalanche deposits more than $50 \mathrm{~m}$ thick form part of the dam's foundation, and its left abutment is in talus (fig. 22) (Paterson, 1971; Thomas, 1976, p. 156; Fell and others, 1992, p. 140-141). Apparently, there have been no difficulties with the debris-avalanche foundation or the talus abutment.

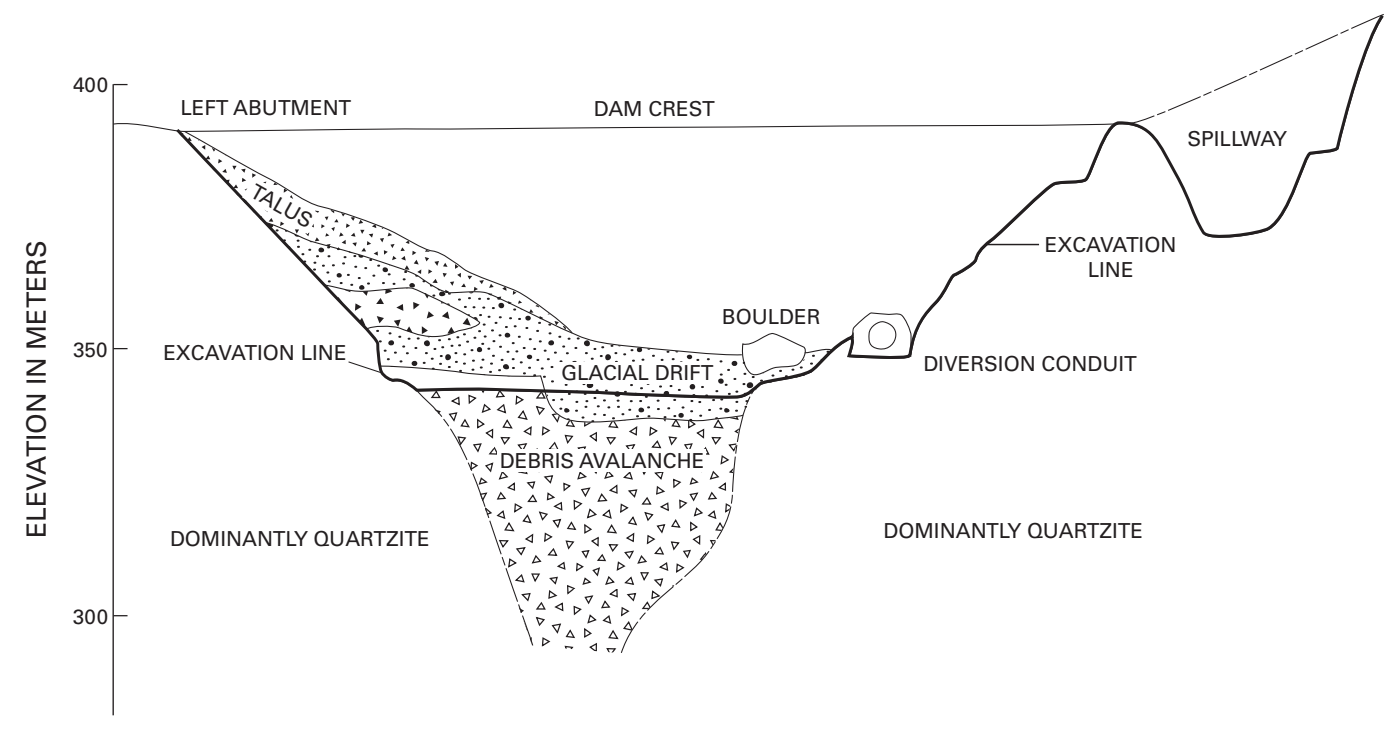

Figure 22. Cross section through the Parangana Dam site, Victoria, Australia, showing debris-avalanche deposits in the foundation and left abutment of the dam and talus deposits in the left abutment. All deposits above the excavation line were removed during construction. Modified from Paterson (1971). 


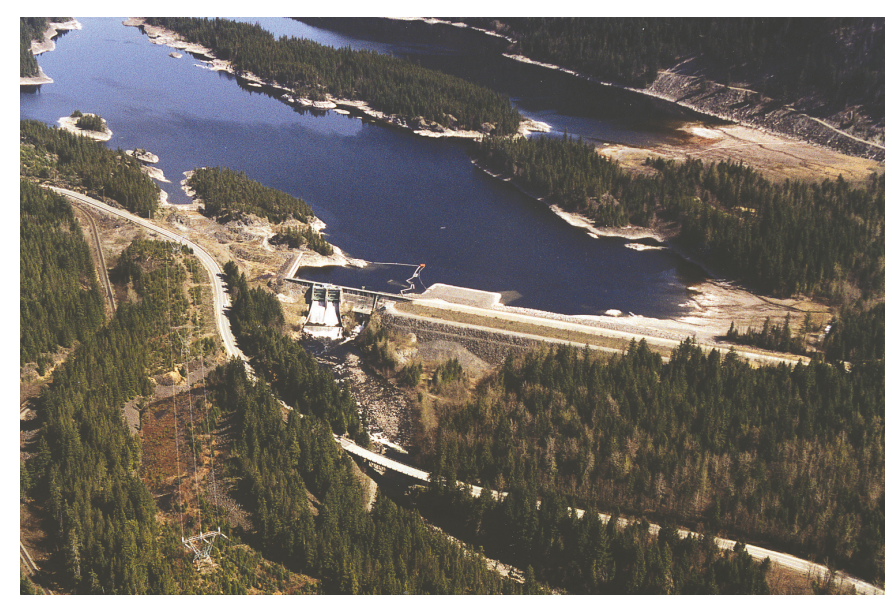

Figure 23. Oblique aerial view of Cheakamus Dam, British Columbia, southwestern Canada. The foundation of the dam is mainly Rubble Creek Wash, a debris avalanche-debris flow deposit (see fig. 24). Photograph taken in 1999 by BC Hydro, Burnaby, British Columbia.

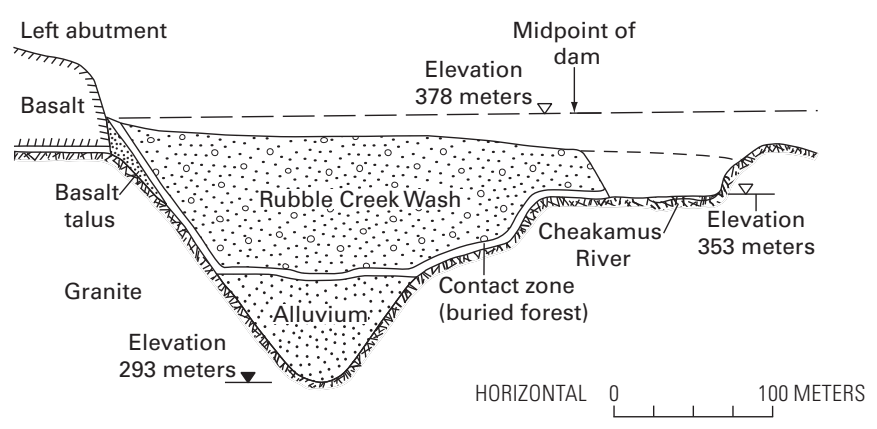

Figure 24. Cross section through the site of Cheakamus Dam, British Columbia, southwestern Canada, showing the location of the Rubble Creek Wash, the remains of an 1855-56 debris avalanche-debris flow deposit, on which the dam was built. Modified from Terzaghi (1960b).

- Cheakamus Dam-Professor Karl Terzaghi served as the geotechnical consultant for Cheakamus Dam, a 28m-high earthfill/rockfill hydropower dam, which was built in 1957 in southwestern British Columbia, Canada (fig. 23). The Cheakamus River valley at the site is partially filled with materials known as "Rubble Creek Wash" (fig. 24), the deposits of a large debris avalanche-debris flow that occurred in 1855-56 (Terzaghi, 1960a,b; Moore and Matthews, 1978). The permeability and stability of these deposits were approved before construction. The only hazard facing Cheakamus Dam and Reservoir seems to be the possibility of another debris avalanche coming from The Barrier, a volcanic mass at high elevation upstream. Such an avalanche might enter the reservoir at high velocity, and could possibly cause overtopping of the dam.

- Smith and Morehouse Dam-In the United States, the only dam known to have been built on a pre-existing debris-avalanche deposit is the 25-m-high Smith and Morehouse Dam, an earthfill structure that was completed in 1988 to provide irrigation water to northcentral Utah. The entire dam foundation is a large avalanche (age 4,000 yr B.P.) of sedimentary rock and glacial debris that filled Smith and Morehouse canyon to a depth of about $60 \mathrm{~m}$. Although the dam was built on this debris avalanche, a cutoff key placed through the debris increased the strength and imperviousness of the foundation.

\section{Debris, Mud, and Earth Flows}

Debris, mud, and earth flows, including flows of volcanic origin, make up the foundations and/or abutments of 24 of the 254 dams listed in Appendix table A. Of these, 17 are conventional debris, mud, or earth flows, and seven are flows of volcanic origin, also known by the Indonesian term lahars. Flow deposits usually are stable, but can be pervious enough to allow seepage through a dam's foundation or abutments. This can pose possible problems for traditional dams. However, a few of the cases noted in this study are debris-retention or sediment-retention structures (also known as check dams or by the Japanese term, sabo dams); for these cases, permeability of the foundation is not a negative factor because these dams are intended to intercept only the solid fractions of the debris flows, not the water. Some examples of the 24 dams are described below.

Several dams in the Pacific Northwest of Canada and the United States have been built on flows, both regular and volcanic. These include Seymour Falls, Mud Mountain, and Swift Dams and the North Fork Toutle River sediment-retention structure.

- Seymour Falls Dam-Seymour Falls Dam on the northern outskirts of Vancouver, British Columbia, Canada, is a 30-m-high earthfill/concrete water-supply dam that was completed in 1961. The right abutment of this dam is a debris-flow cone from a tributary stream (Ripley and Campbell, 1963). The cost of an impervious cutoff through the debris cone to bedrock was considered to be prohibitive. Instead, an extensive impervious upstream blanket was installed to minimize seepage through the debris-cone abutment and the foundation (Heidstra and others, 1995).

- Mud Mountain Dam-Several major dams have been built on debris flows or mud flows (lahars) that originated from volcanoes in the Cascade Range of southwest Washington State, United States. Mud Mountain Dam is a 130-m-high earthfill flood-control dam that 


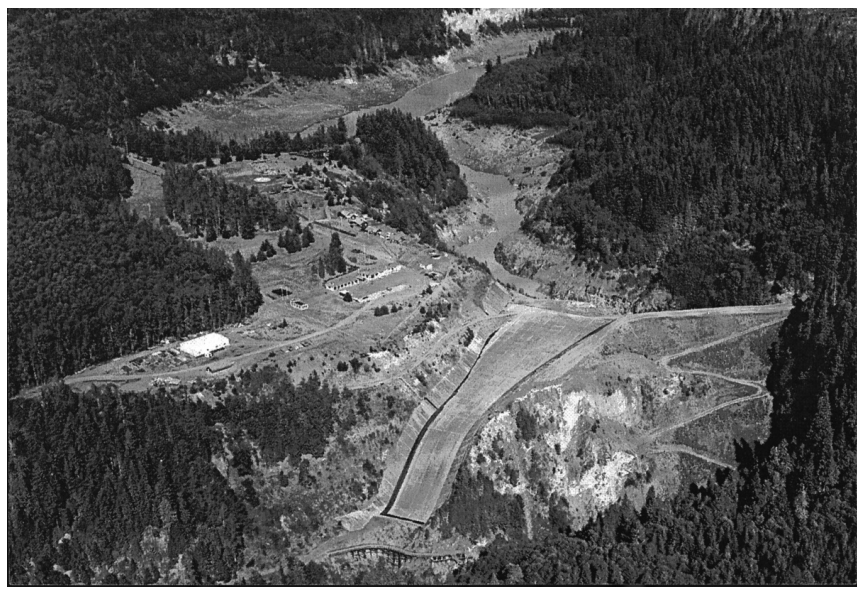

Figure 25. Aerial-oblique view of Mud Mountain Dam, western Washington State, United States. At both banks of the White River, the dam abuts into a Pleistocene mud-flow (lahar) deposit from Mount Rainier volcano. Photograph taken in 1979 by U.S. Army Corps of Engineers.

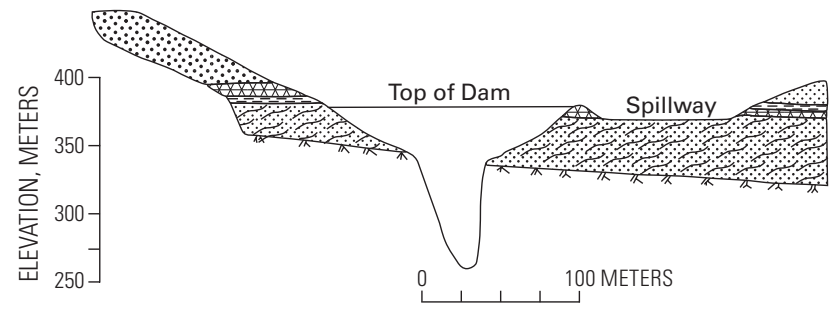

EXPLANATION

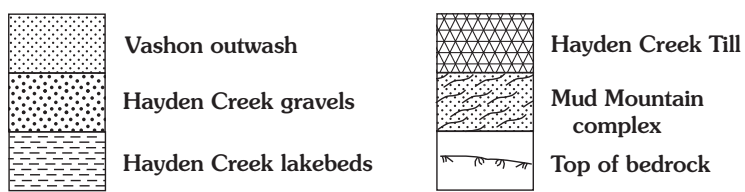

Figure 26. Cross section through the site of Mud Mountain Dam, Washington State, United States, showing the Mud Mountain complex (Pleistocene mud-flow deposits) in both abutments. Modified from Galster (1989b).

was completed in 1948 on the White River, a glacial stream from Mount Rainier (fig. 25). At both banks of the river, the dam abuts Pleistocene mud-flow deposits (Mud Mountain complex) (fig. 26) from Mount Rainier, which at the time of construction were thought to be glacial debris (Galster, 1989b; Eckerlin, 1992, 1993). Fortunately, these deposits are nearly impervious and are generally stable, particularly because they are buttressed by the dam. The only difficulties at this site have involved slides along the reservoir shore, which have not directly affected performance of the dam.

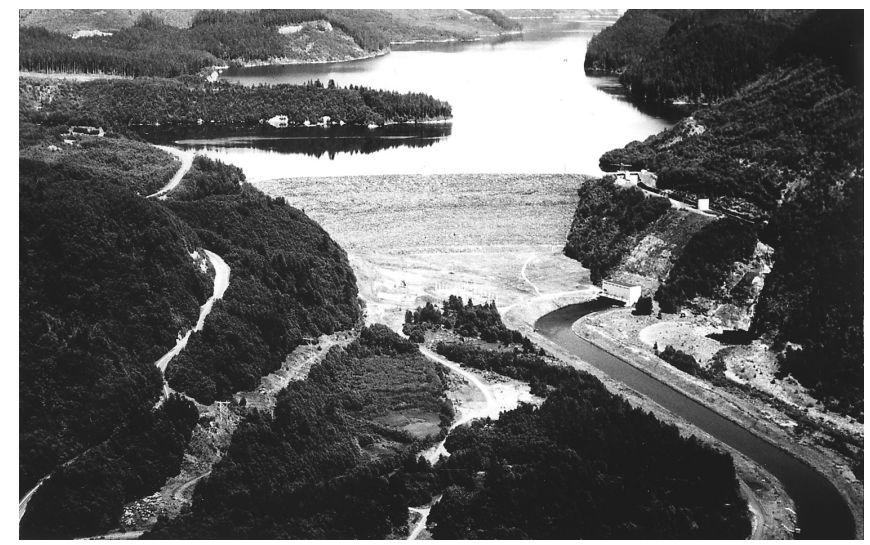

Figure 27. Aerial view of Swift Dam, Lewis River, western Washington State, United States, showing forested debris-flow deposits that form the right abutment of the dam (see fig. 28). Photograph by Lynn Topinka, U.S. Geological Survey.

- Swift Dam-Farther south in the Cascade Range of Washington State, two hydropower dams have been built on prehistoric lahars in the valley of the Lewis River, a glacial stream from the southeastern slopes of the cone of Mount St. Helens. The upstream structure is Swift Dam (fig. 27), a 126-m-high earthfill dam that was completed in 1958. Swift Dam's right abutment and foundation are a thick, well-consolidated volcanic debris flow from a prehistoric eruption of Mount St. Helens (fig. 28) (Jensen, 1981; Tilford and Sullivan, 1981; Bliton, 1989). In the channel, an open-cut excavation for an impervious cutoff was made through this debris-flow material to a depth of about $30 \mathrm{~m}$. Sheet piling was then driven to bedrock from the bottom of the trench $(\sim 25 \mathrm{~m})$. A positive seal was formed by a grout curtain ranging in depth from 6-30 $\mathrm{m}$ and reaching into volcanic bedrock (Lowe, 1988). The right end of the dam was built on the lahar abutment with a drainage gallery to intercept any seepage. The system is operating successfully.

- Yale and Yale Saddle Dams_-Yale Dam, a 98-m-high earthfill structure, also on the Lewis River, approximately $20 \mathrm{~km}$ downstream from Swift Dam, was completed in 1953. As is the case for Swift Dam, the Lewis River valley at the Yale Dam site was partly filled by prehistoric lahars from Mount St. Helens. A geologic map by Tilford and Sullivan (1981) shows the distribution of these lahar deposits at and near the damsite (fig. 29). The lahar deposit was excavated from under the impervious core of the dam; however, the papers cited do not make it clear whether it remains under the outer shell. Three kilometers north of Yale Dam is Yale Saddle Dam, a 12-m-high earthfill structure that helps to impound Yale Reservoir; this saddle dam is founded entirely on lahar deposits. Neither dam has shown dis- 


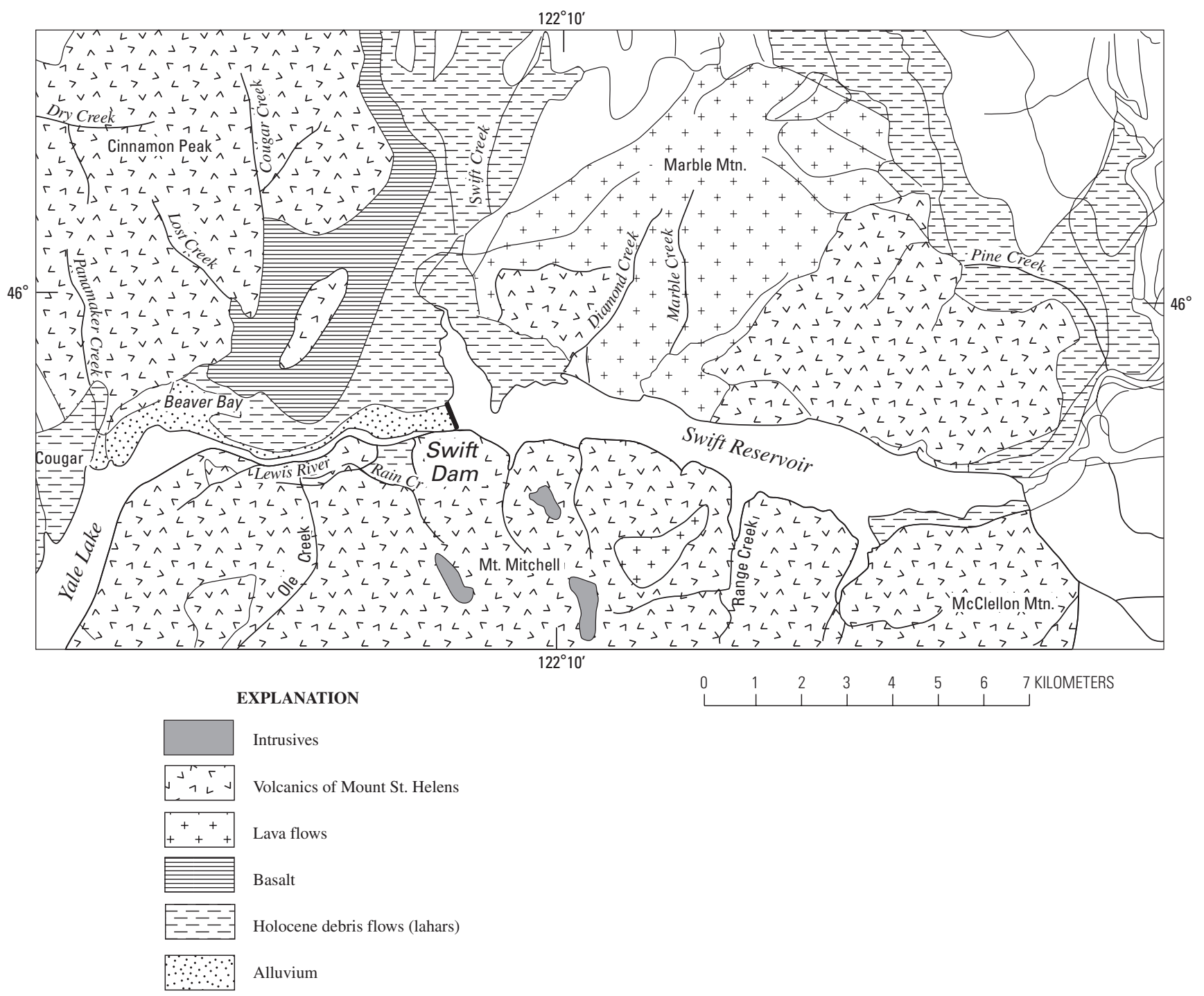

Figure 28. Geologic map of the area around Swift Dam, Washington State, United States, showing the distribution of Holocene debris flow (lahar) deposits that form the right abutment of the dam. Modified from Tilford and Sullivan (1981). 


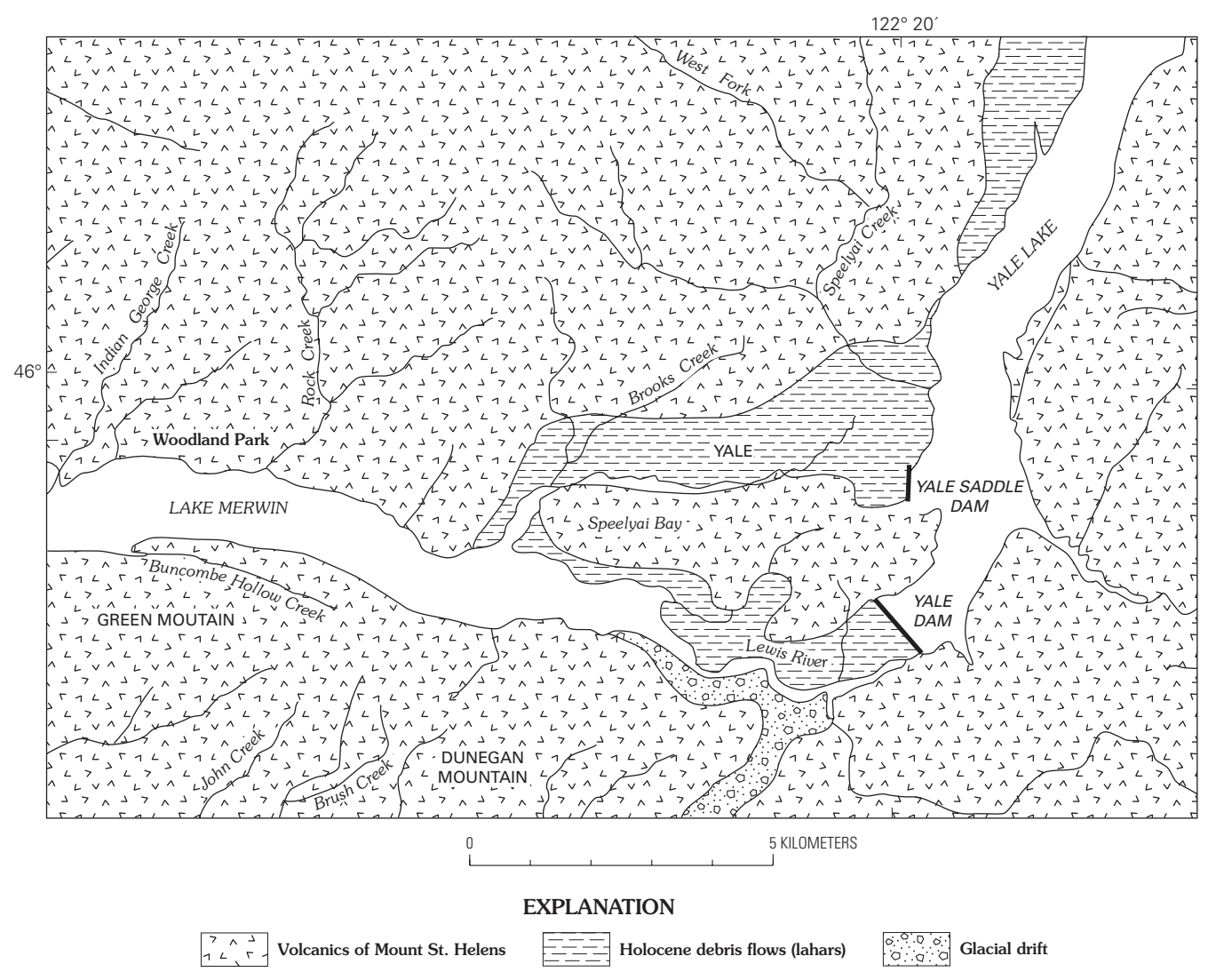

Figure 29. Geologic map of the area around Yale Dam and Yale Saddle Dam, Washington State, United States, showing the distribution of Holocene debris-flow (lahar) deposits that form the dams' foundations and abutments. Modified from Tilford and Sullivan (1981).

tress due to the debris-flow materials in the foundation or abutments, and they continue to perform well.

- North Fork Toutle River sediment-retention structureAnother dam on Mount St. Helens debris-flow deposits is the sediment-retention structure (SRS) built in 1988 on the North Fork Toutle River to retain debris-flow material that is washed from the surface of the 1980 debris avalanche, as well as any future debris flows that might come down the valley (Schuster, 1989). This 73-m-high earthfill dam (fig. 30) was constructed on at least $30 \mathrm{~m}$ of debris-flow material from the 1980 eruption and previous eruptions of Mount St. Helens. The dam is stable, and thus far is performing well (Bernton, 2000). The debris-retention function of this dam was augmented by the 1984-85 construction of an outlet tunnel from debris-avalanche-dammed Spirit Lake, the source of the North Fork Toutle River (Sager and Budai, 1989). This 2.6-km-long bedrock tunnel was built to prevent overtopping and failure of the debris-avalanche dam, which could have resulted in a catastrophic outburst debris flow, the volume and force of which might have overwhelmed the planned debrisretention structure.

Medeo Dam on the Malaya Alma-Atinka River and an unnamed dam on the Bolshaya Alma-Atinka River upstream from the city of Almaty in Kazakhstan are two other very successful debris-retention dams that have been founded on preexisting debris flows. Both were built to protect Almaty from the catastrophic debris flows that had entered the city from the Tien Shan Range every few years.

- Medeo Dam-The original 110-m-high Medeo Dam (fig. 31) on the Malaya Alma-Atinka River was built in 1968-69 by setting off explosive charges in the valley walls to form a man-made "landslide" dam that is founded on valley-bottom debris-flow deposits (Yesenov and Degovets, 1979, 1982). In July 1973, Medeo Dam retained a debris flow with a volume of about 5.5 million $\mathrm{m}^{3}$ and maximum discharge of $10,000 \mathrm{~m}^{3} / \mathrm{sec}$ that came from the outburst of a moraine-dammed lake on the upper Malaya Alma-Atinka River (Yesenov and Degovets, 1982; Popov, 1999). As a result, the retention basin of the Medeo Dam was nearly filled. 


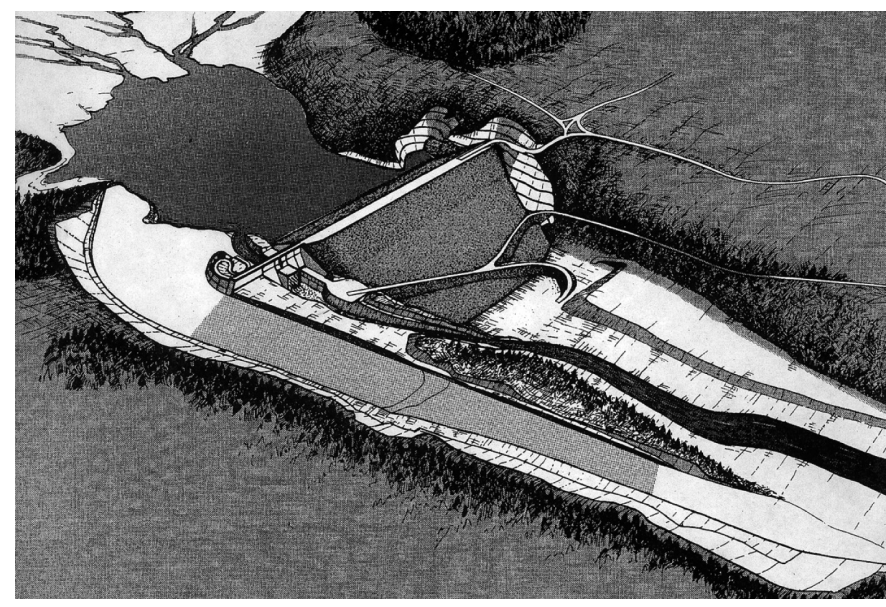

Figure 30. Sketch of the earthfill sediment-retention dam (SRS Dam) on the North Fork Toutle River, southwestern Washington State, United States. This dam, which was constructed in 1988 to intercept sediment and debris washed downstream from the debris avalanche triggered by the 1980 eruption of Mount St. Helens, is founded on debris-flow deposits (Schuster, 1989). Sketch by U.S. Army Corps of Engineers.

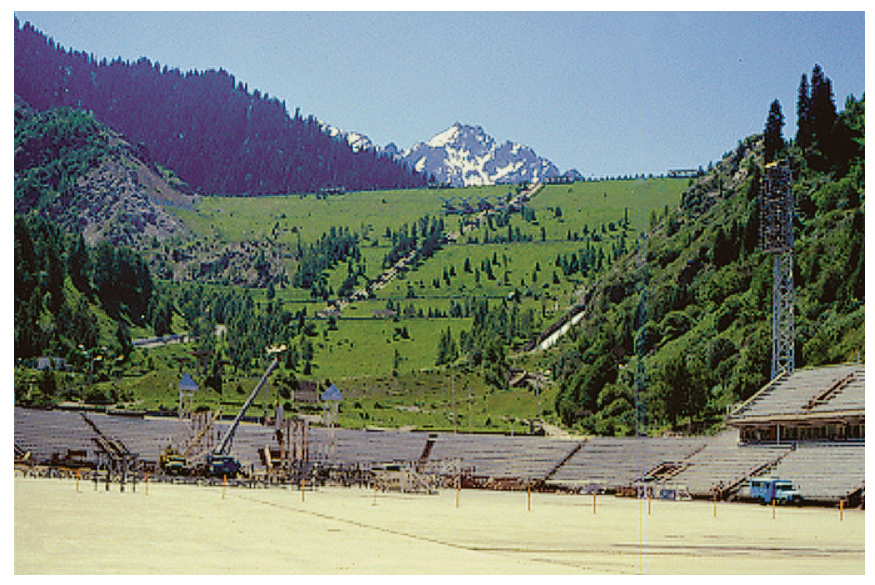

Figure 31. Medeo Dam, a debris-flow retention structure on the Malaya Alma-Atinka River in Kazakhstan, which is founded on debris-flow deposits. Photograph taken in 2001.

To contain future flows, the original earthfill dam was raised to a height of $150 \mathrm{~m}$ by traditional construction methods, providing a new retention basin with a volume of 12.6 million $\mathrm{m}^{3}$.

- Unnamed debris-retention dam on the Bolshaya AlmaAtinka River-In 1982, a 40-m-high cellular reinforced-concrete dam (fig. 32) was built on debris-flow deposits in the valley of the Bolshaya Alma-Atinka River north of Almaty for the same debris-retention purpose as Medeo Dam. The retention-basin volume of

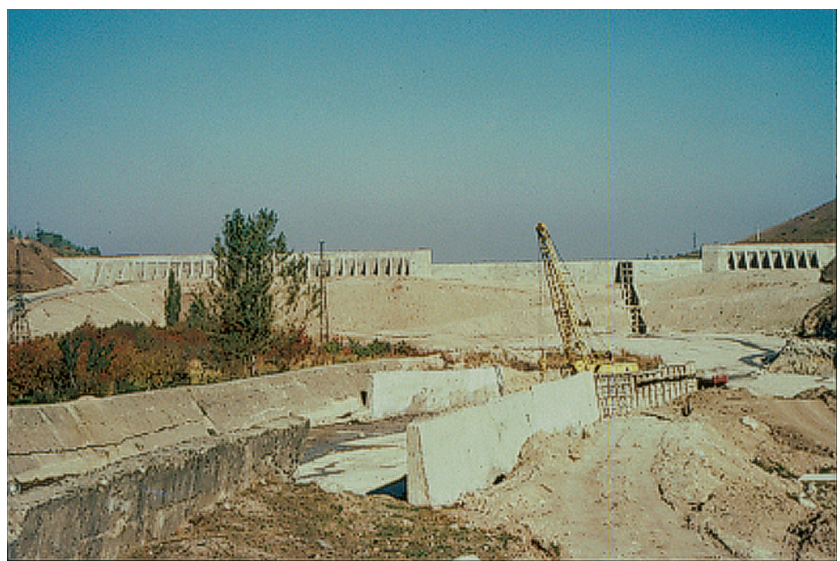

Figure 32. Photograph of construction of a cellular reinforced-concrete debris-retention dam on the Bolshaya Alma-Atinka River of Kazakhstan. This 40-m-high dam, which was built in 1981-82 to protect the city of Almaty from the many debris flows from the Tien Shan Range, is founded on debris-flow deposits. Photograph taken in 1981 by D.J. Varnes, U.S. Geological Survey.

the Bolshaya Alma-Atinka Dam is about 14.5 million $\mathrm{m}^{3}$ of debris-flow material (Yesenov and Degovets, 1982).

There are many debris-flow retention dams (sabo dams) in China, Indonesia, and Japan. Most of these are small check dams and most have been built on bedrock. The following are two examples of debris-flow-retention dams that have been built on landslides.

- Hunshui Gully debris-retention dam \#4-An example from Yunnan Province, China, which qualifies as a "large dam" that was built on pre-existing debris-flow deposits is the 16-m-high Hunshui Gully debrisretention dam \#4, a stone and concrete structure that was completed in about 1979-81 ( $\mathrm{Li}$ and Luo, 1981; Zhang and others, 1985). This dam is one of a series of debris-retention structures built from 1978 to 1981 to intercept nonvolcanic debris flows on tributaries of the Xiao River (itself a tributary of the Yangtze River).

- Jinnosuke \#5 sabo dam-An example from Ishikawa Prefecture, Japan, is 17-m-high Jinnosuke \#5 sabo dam, which is the largest of more than 50 sabo dams built on a pre-existing slide in altered sandstone, shale, and rhyolite in the valley of the Tedori River (Fukuoka and Taniguchi, 1961; Ohta and others, 1996; Wang and others, 2003; Okuno and others, 2004). The original Jinnosuke \#5 Dam has moved about $5 \mathrm{~m}$ since it was built in 1925, and was recently rebuilt as a new Jinnosuke \#5. There are several other dams in the valley 
that are 10-m high or higher; even though these dams are slowly moving, all are successfully fulfilling their debris-retention function.

Of the many other debris-retention structures in these countries, a few undoubtedly are large dams that have been built on debris-flow foundations. However, I don't have sufficient information on these dams to include them here or in Appendix table A.

\section{Cambering and Valley Bulging}

Cambering and valley bulging have been noted in England as valleyward toppling of blocks of periglacial soils (Hutchinson, 1988). According to Cruden and Varnes (1996), a camber in rock may be described as a "relict, complex rock spread-rock topple." When occurring in periglacial soils, it would be known as a relict, complex soil spread-soil topple.

- Empingham Dam-During construction in 1975 of Empingham Dam, a 40-m-high earthfill water-supply dam in northern England, cambering and valley bulging in "boulder clay" (glacial till) were encountered in the foundation excavation (Horswill and Horton, 1976). The cambering and resulting valley bulging had no negative effects on dam construction or performance.

\section{Problems Encountered Due to Interaction Between Dams and Landslides}

Landslides in dam foundations or abutments may lead to instability of the dam or seepage within these units. Example case histories in which these problems have occurred are discussed below.

\section{Abutment and Foundation Instability}

Of the total of 254 dams in Appendix table A, 78 encountered abutment-slope or foundation movement either during construction (43 cases) or after completion of the dam (35 cases). For most construction-triggered failures, all or most of the active material was removed. In a few cases, it was left in place and stabilized, often by the buttressing effect provided by construction of berms or by the dam itself. There are only a very few known cases in which postconstruction movement affected or threatened the overall stability of the dam; St. Francis Dam (discussed earlier) and B.F. Sisk Dam, both in California, United States, are outstanding examples.

- B.F. Sisk (San Luis) Dam-An excellent example of landslide activity in an abutment after construction is
B.F. Sisk (San Luis) Dam in central California. This 116-m-high earthfill dam, which was built for irrigation, hydroelectric power, and recreation, was completed in 1967. During drawdown in September 1981, a slide originated in "hard clay" slopewash of the left abutment and passed through the upstream face of the dam (Von Thun, 1985) (fig. 33). The slide moved about $20 \mathrm{~m}$. The main mass of the dam remained stable, and the reservoir was not threatened. Remedial measures consisted of construction of a buttressing berm at the upstream toe of the dam and reconstruction of the upstream face.

In addition, three cases of failure at an abutment that included a pre-existing landslide have happened under flood conditions; a basic underlying cause of failure for each was probably the presence of a relatively easily erodible landslide. The three cases are (1) Cheurfas Dam, Algeria, which failed in 1885, (2) Euclides da Cunha Dam, Brazil, which failed in 1977, and (3) Star Mountain Dam, Oregon, United States, which failed in 1983.

- Cheurfas Dam-The right abutment of the original 37m-high, masonry Cheurfas Dam in Algeria was in talus and alluvium (fig. 34) (Gignoux and Barbier, 1955). In 1885, a flood removed the right one-half of the dam, which was later rebuilt (see below). Cheurfas Dam has not been included in Appendix table A because I was unsuccessful in obtaining sufficient data on the original dam.

- Euclides da Cunha Dam-Euclides da Cunha Dam is a 92-m-high earthfill structure in southeastern Brazil. The original dam was completed in 1960 to provide hydroelectric power. "Ancient landslides," consisting of clayey talus, covered both abutments (Vargas, 1971; Brazilian Committee on Large Dams, 1982). Torrential rains in January 1977 generated a flood that quickly overtopped the dam, causing severe erosion of the right abutment and resulting failure of the dam. Almost all of the talus on the right abutment was removed by the force of the flood. Thus, when the dam was subsequently rebuilt, seepage was better controlled at that end of the dam than it was before the failure.

- Star Mountain Dam-The 1983 failure of 21-m-high Star Mountain Dam, an earthfill dam built in 1961 to provide local irrigation water to southeastern Oregon, is a similar case to that of the failure of Euclides da Cunha Dam. The entire right bank of Granite Creek at the damsite is the toe of a large pre-historic landslide. In late March 1983, a flood eroded out the original spillway, which was at the contact between the dam and the landslide abutment, causing damaging downstream flooding (Holton, 1983). The landslide character of the abutment probably was a factor in the failure of the spillway. When the dam was reconstructed, the 


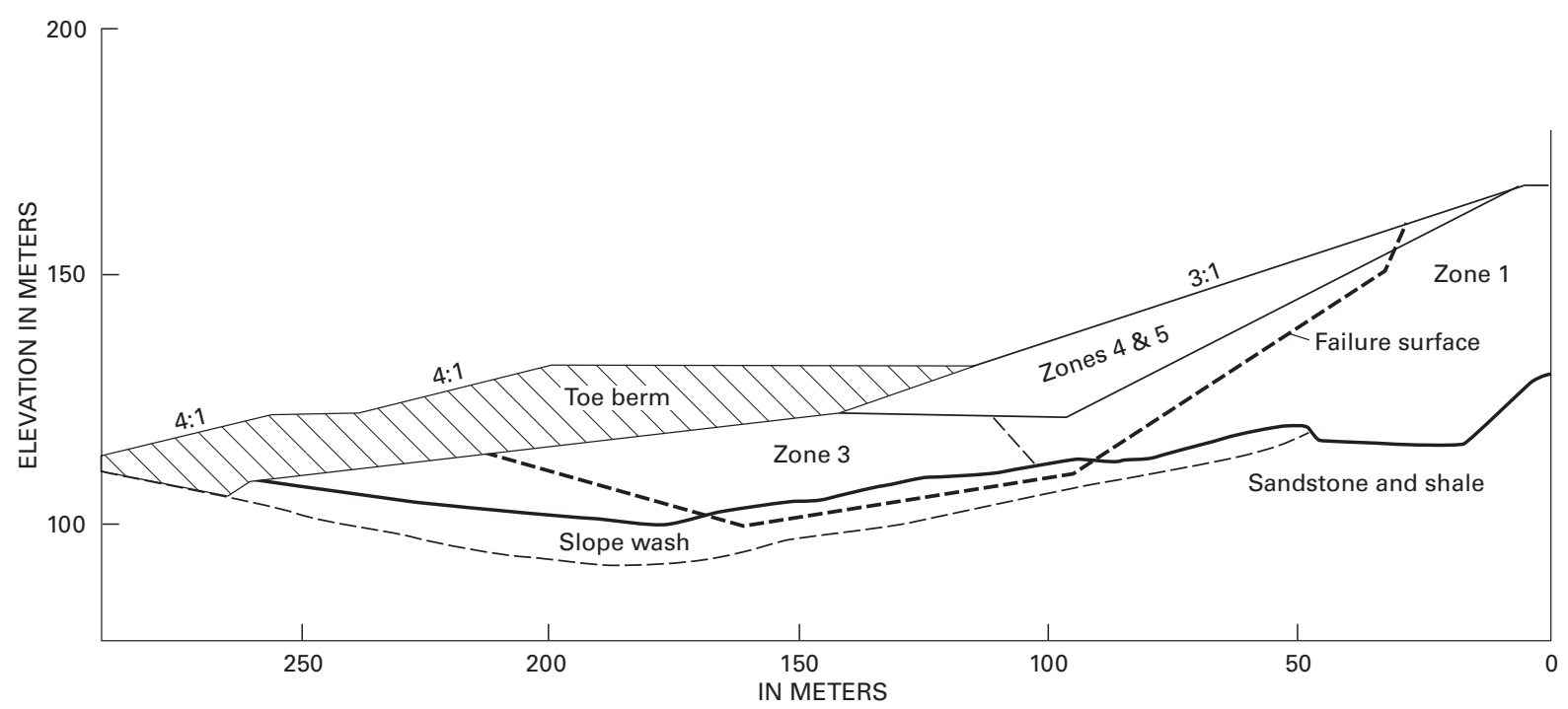

Figure 33. Cross section through B.F. Sisk (San Luis) Dam, California, United States, showing the location of the postconstruction slide surface and the toe berm installed to stop further movement. The slide surface passed through slope wash and zones 1 and 3 of the dam. Modified from Von Thun (1985).

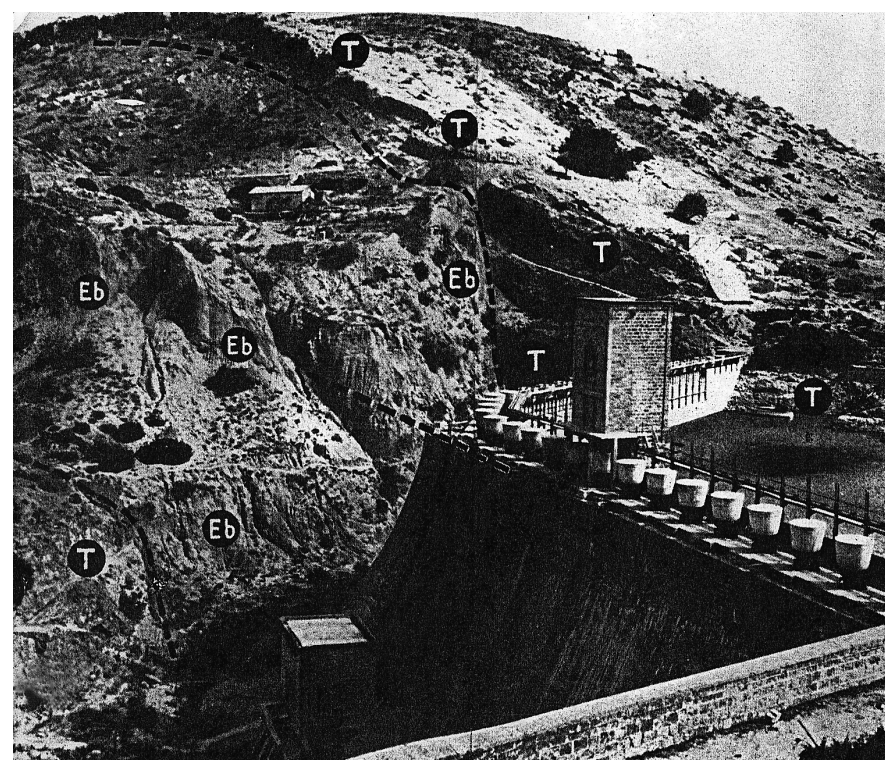

Figure 34. Cheurfas Dam, a masonry dam in Algeria. This dam was originally built in $1880-82$, at a time when only very superficial geologic studies were made. As a result, the right abutment consisted of talus and alluvial debris. After the dam failed at its right end in 1885 due to a flood, it was rebuilt to a bedrock abutment slightly upstream, leaving a "dogleg" in the dam (Gignoux and Barbier, 1955, p. 208-209). Note: "Eb" is éboulis, which translates as "debris," or, in this case, talus and alluvium; "T" is limestone. Photograph by M. Gignoux, courtesy of Dunod/ Masson Sciences, Paris. 


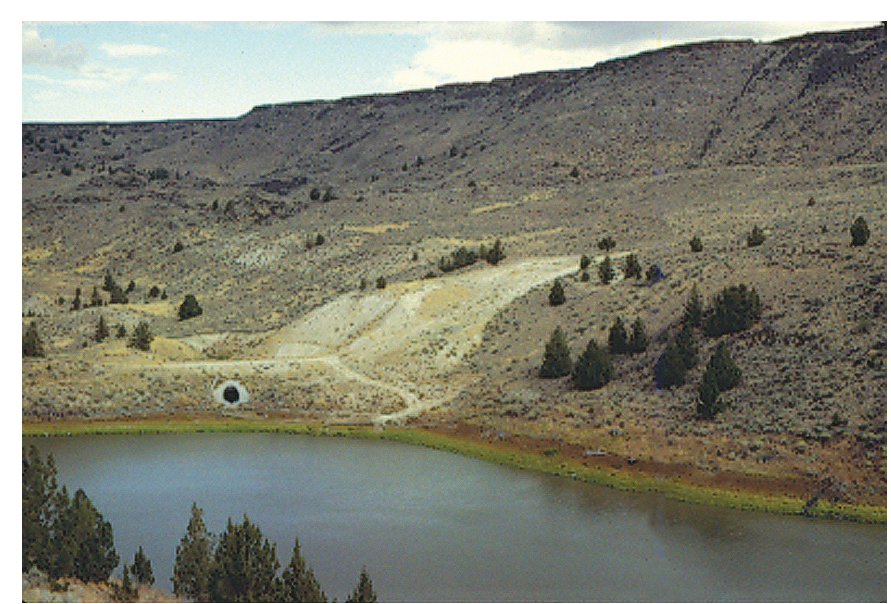

Figure 35. Star Mountain Dam, a 21-m-high irrigation dam in southeast Oregon, United States. The right abutment of this dam is the toe of a large landslide. After the dam failed in 1983 due to flood erosion of the unlined spillway at the landslide right abutment, a circular concrete-lined spillway was installed within the embankment. Photograph taken in 1998.

original surface spillway was replaced by a circular-concrete spillway embedded in the embankment (fig. 35).

\section{Abutment and Foundation Seepage}

Of the 254 dams in Appendix table A, 59 have had unanticipated seepage problems, most commonly through an abutment. Of these 59 cases, 51 are in the Western United States, a result of the large number of irrigation dams that were built in this area in the early part of the 20th century without adequate geologic exploration or foundation/abutment design. Another reason for the tabulation of so many Western U.S. dams that have reported seepage problems may be the readily available technical information on U.S. dams from State dam-safety agencies. Furthermore, it also is possible that seepage from non-U.S. dams has been underreported in the technical publications from which the data in Appendix table A were obtained.

- Ochoco Dam-Probably the most outstanding example of seepage through a landslide abutment of a Western United States irrigation dam is provided by Ochoco Dam, a 38-m-high hydraulic-fill dam built in 1920 in central Oregon. The right abutment and the foundation of the right end of this dam is a massive late Pleistocene rock slide-lateral spread (fig. 36) that probably resulted from plastic flow of bentonitic zones in dacitic tuff and tuffaceous claystone that underlay welded rhyolitic tuff of the slide mass (Carter, 1998a,b;

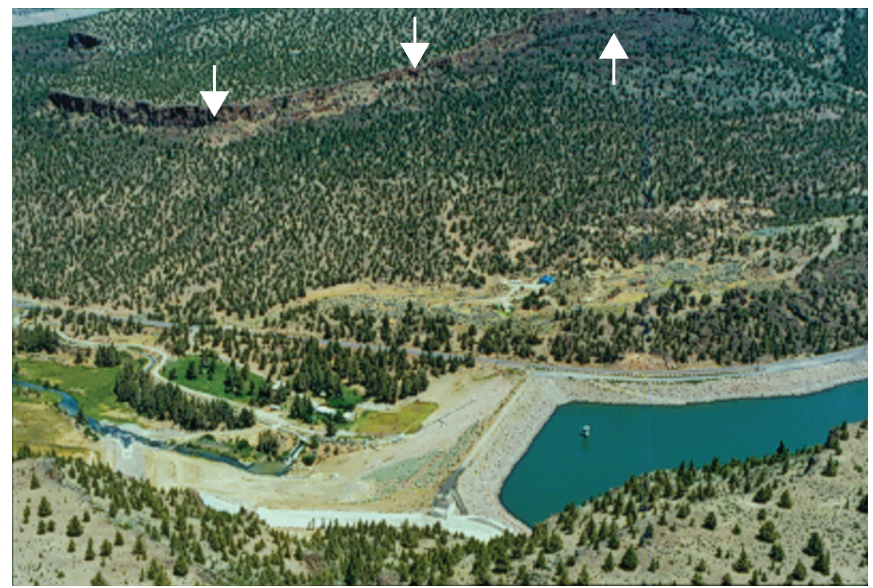

Figure 36. Oblique-aerial view of Ochoco Dam, central Oregon, United States, and the huge rock slide-lateral spread that serves as its right abutment. Note the long head scarp (marked by arrows) of the slide along the upper part of the ridge. Photograph taken in 1999 by U.S. Bureau of Reclamation.

Kunzer, 1998). Right-abutment seepage occurred during the first filling of the reservoir. Upstream right-abutment treatment in 1921 reduced this seepage from an estimated $100,000 \mathrm{~m}^{3} /$ day to $70,000 \mathrm{~m}^{3} /$ day. In 1950, additional modifications at the right end of the dam further reduced the seepage to approximately $25,000 \mathrm{~m}^{3} /$ day. Complete reconstruction of the right end of the dam and its immediate abutment during the 1990s has reduced seepage to acceptable levels.

- Howard Hanson Dam-Another Western U.S. example of seepage problems due to landslide material in an abutment is Howard Hanson Dam, a 72-m-high rockfill and earthfill flood-control dam that was built in 1962 in the Cascade Range of southwestern Washington. The right abutment for this dam is the toe of a large landslide in Tertiary andesite flows, andesitic tuffs, and breccias (fig. 37). The slide debris consists of a heterogeneous assemblage of rock blocks as large as $6 \mathrm{~m}$ in diameter in a matrix of finer debris (Galster, 1989a). After the first filling of the reservoir in 1965, a spring abruptly issued from the landslide materials about $100 \mathrm{~m}$ downstream from the right abutment. The spring originally flowed at about $450-550 \mathrm{~m}^{3} /$ day. Flow has since been controlled by a gravel blanket supported by a crib wall. A drainage adit was added in 1968. This system seems to adequately control abutment leakage through the slide debris. 


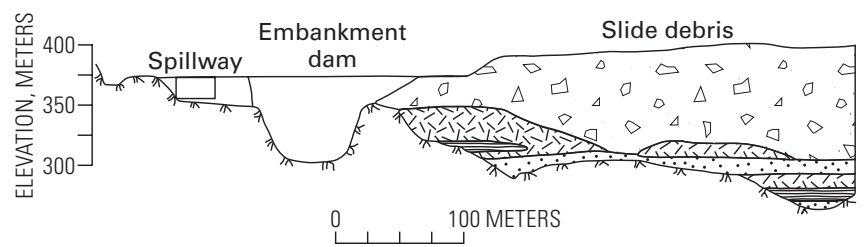

EXPLANATION
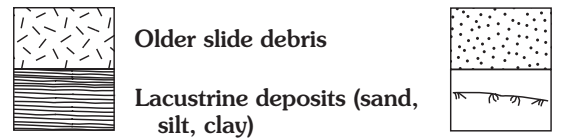

Fluvial deposits (sand and gravel) Bedrock surface

Geology after Corps of Engineers unpublished data

Figure 37. Cross section through the site of Howard Hanson Dam in western Washington State, United States, showing the huge landslide that serves as the right abutment of the dam. Modified from Galster (1989a).

\section{Mitigative Measures}

Procedures used to prevent or alleviate problems encountered because of the existence of landslides at potential or actual damsites can be broadly subdivided into two main categories:

- Planning measures-These include those measures that avoid or alleviate the problems as part of the planning process (passive measures). Common measures are avoidance, dam-type selection, control of reservoir level, and/or relocation of the spillway.

- Physical prevention or remediation measures (active measures)_-These commonly include removal of all or part of the landslide; flattening of the slope; construction of berms that serve as buttresses; and installation of impervious membranes or cutoffs, retaining walls, surface or underground drains, and rock-anchor systems. These physical prevention and remediation measures have been used in the abutments or foundations of 154 of the dams in Appendix table A. Seventy-seven of the 101 non-U.S. dams utilized active measures, as was the case for 77 of the 153 U.S. dams. As presented in Appendix table A, of the 154 dams that were subject to active prevention and remedial measures, the use of individual types of prevention and remediation are as follows (note, however, that multiple types have been used on many dams): partial removal of landslide deposits (46 dams), cutoff walls (43 dams), berms/buttresses (43 dams), grouting (36 dams), drainage (36 dams), impervious membranes/ blankets (20 dams), flattening of abutment slopes (15 dams), rock anchors (12 dams), piles/piers (8 dams), guniting/dental work (six dams), retaining walls (5 dams), and other measures (6 dams). Another, sometimes overlooked, physical measure is the buttressing effect of the dam itself, which has proven to be a very important factor in the retention of many abutment landslides.

\section{Planning Measures}

\section{Avoidance of Landslides}

A very basic passive preventive measure if a landslide has been recognized in a planned foundation or abutment area during the siting process is avoidance, that is, relocation to a more favorable site nearby, or, in extreme cases, complete abandonment of the site.

\section{Relocation of Site}

Several cases have been noted in which a damsite was relocated because the original site included a hazardous landslide in the foundation or an abutment. Most of these dams have not been included in Appendix table A because as constructed they do not interact with landslides. Notable examples include the following:

- Orlik Dam-The most often cited example of relocation of a major dam because of a pre-existing landslide has been that of Orlik Dam on the Vltava River in the southwestern part of the Czech Republic (Záruba, 1965; Záruba and Mencl, 1976; Legget and Karrow, 1983; Legget and Hatheway, 1988). Preliminary studies for the siting of Orlik Dam indicated that a narrow stretch of the valley and the existence of Proterozic metamorphic rocks in the abutments would provide an ideal site for construction of a concrete-gravity dam. However, further study found that the narrowing of the valley at the site was actually caused by a massive Pleistocene rock slide. The original site was abandoned and a new site selected $200 \mathrm{~m}$ upstream, where the 91-m-high dam was successfully completed in 1963. For the same reason, several other potential damsites on the Vltava River have had to be relocated or abandoned.

- Salagou Dam-In the case of Salagou Dam on the Salagou River in south-central France, the site was relocated only a short distance away (Comité Français des Grandes Barrages, 1982). In addition to removing $87,600 \mathrm{~m}^{3}$ of landslide material from the right abutment of the site and $38,450 \mathrm{~m}^{3}$ from the left abutment, the 63-m-high earthfill dam was moved upstream-the right end a distance of $40 \mathrm{~m}$ and the left end $80 \mathrm{~m}$ - to avoid building on landslide materials. Construction was completed successfully in 1971. 
- Kotmale Dam-Kotmale Dam, an 87-m-high rockfill dam on the Kotmale Oya (river) in Sri Lanka, was completed in 1985 to produce hydroelectric power. As construction began, a landslide was noted in the left abutment, necessitating relocation of the dam site $200 \mathrm{~m}$ downstream where it avoids any landslides (Kumara and Kulasinghe, 1987).

- Talbingo Dam-The original site for Talbingo Dam, a 161-m-high rockfill hydroelectric dam in the Snowy Mountains of southeastern Australia, included the toe of a large landslide of weathered basalt in the left abutment (Fell and others, 1992, p. 58). An alternative landslide-free site, more than $100 \mathrm{~m}$ upstream, was selected. The dam was completed in 1971, incorporating 2.3 million $\mathrm{m}^{3}$ of the basaltic landslide deposit for its impervious core.

- North Fork Dam-An example of landslide avoidance during the original exploration stage of site selection is that of North Fork Dam, a hydroelectric dam on the Clackamas River in northern Oregon, United States. During site exploration for this 63-m-high concretearch dam, a 25-30 m thick deposit of slide and talus debris was noted in the left-abutment area (O'Reilly, 1958). As a result of this preliminary exploration, the dam was relocated upstream utilizing an abutment of stable basalt and was completed in 1958.

- Casitas and Castaic Dams-As indicated in Appendix table A, the axes of Casitas and Castaic Dams, California, United States, were realigned in the planning stage to minimize the effects of pre-existing landslides (Hanegan, 1973). In both cases, final alignment placed only a small part of the dam in contact with a landslide.

- San Dimas Dam-San Dimas Dam, California, was redesigned to reduce the area of contact of the dam with a pre-existing landslide.

There also have been a few cases in which one end of a pre-existing or partially built dam has been diverted to avoid a landslide, thus forming a "dogleg" in the dam. Three cases (not included in Appendix table A) where the axes of dams have been diverted midstream in order to avoid landslides are Cheurfas Dam (Algeria), Scott Dam (California, United States), and Gogoşu Dam (Romania).

- Cheurfas Dams-As briefly mentioned earlier, the original Cheurfas Dam (Cheurfas I) was a masonry dam built from 1880-82 at a time when only very superficial geologic studies were made of the damsite (Gignoux and Barbier, 1955, p. 63); for this reason the right end of the dam abutted against alluvium and talus deposits ("partially strengthened scree"). In 1885, a severe flood carried away the right one-half of the

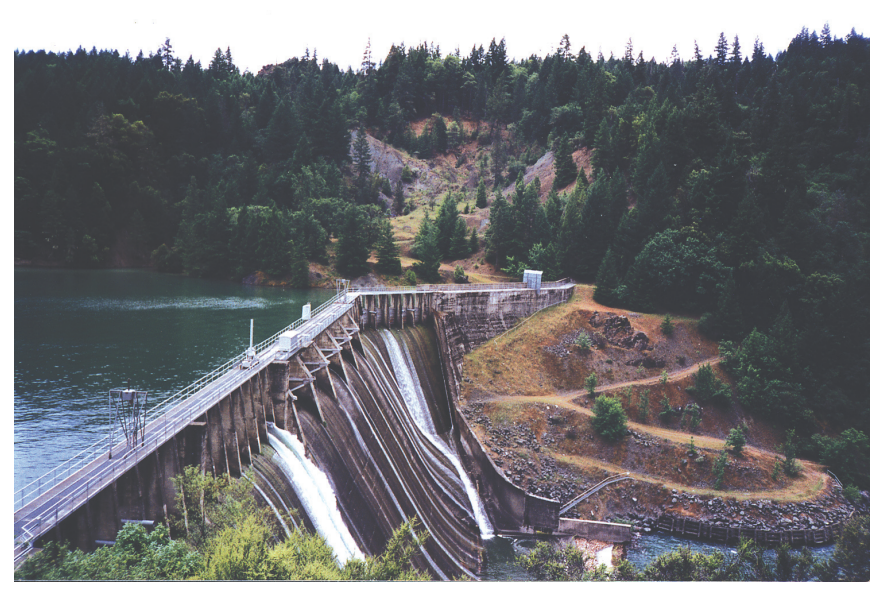

Figure 38. Scott Dam on the Eel River, northern California, United States. During construction in 1921, the left end of this dam was diverted downstream to miss the landslide on the left bank of the river, resulting in a "dogleg" in the dam. Photograph taken in 1997 by J.C. Gamble, Pacific Gas and Electric Company, San Francisco.

structure. By 1892, the dam had been rebuilt, leaving in place the left-end remnant that had survived the 1885 flood, but putting a "dogleg" in the dam to allow its right end to abut a stable limestone outcrop upstream from the unstable talus that formed the original right abutment (fig. 34) (Gignoux and Barbier, 1955; p. 63, 208; Walters, 1971, p. 313-320). During the early 1980s, it was decided to replace the 1892 dam because of siltation in the reservoir and the general instability of the site (Ajabi and others, 1991). The new dam (Cheurfas II) was built upstream at a more stable site.

- Scott Dam-Scott Dam (also known as Pillsbury Dam), a 42-m-high concrete-gravity structure on the Eel River in northwestern California, was built in 1921 to produce hydroelectric power. Construction began at the right end of the dam. When the dam was two thirds of the way across the river, it was realized that the planned left abutment was actually a "floater" of serpentinite in a slide of softened, weathered serpentinite and serpentine clay. The engineers in charge decided to divert the remainder of the dam downstream to miss the landslide, forming a "dog leg" (fig. 38) similar to that for Cheurfas Dam, which was described above (Kiersch and James, 1991; Goodman, 1993).

- Gogoşu Dam-Gogoşu Dam on the Danube River in Romania is a 24-m-high zoned earthfill dam that provides hydroelectric power to the nation. During construction, a slide occurred in the stiff, marly clays that formed the left abutment. In addition to partially removing the slide material, the left end of the dam axis was "upstream curved" to miss the slide area (Corda, 1988). 


\section{Site Abandonment}

An option that can be considered in extreme cases is to abandon the damsite because the landslide problem at the chosen site is without a solution that is economically feasible, and because no suitable alternate site is available nearby. The literature search noted only two cases in which the original site was deemed completely unsuitable and was abandoned. These two cases are a site on the Romanche River in France and the Ok Ma tailings dam site in Papua New Guinea. Abandoned dam sites are not included in Appendix table A.

- Romanche River site-An apparently morphologically suitable site for a dam was located on the upper Romanche River in the French Alps (Gignoux and Barbier, 1955, p. 88; Záruba and Mencl, 1982, p. 238; Bowen, 1984, p. 311-312). The left abutment at this site was composed of stable granite and Triassic sandstones and limestones. The more moderately sloping right abutment also appeared to be stable. However, geologic investigation of the slope found that the entire right side of the valley at the site consisted of a landslide in Lias (Lower Jurassic) shales, which had constricted the valley, and overlay alluvial sandy gravels on the original valley floor (fig. 39). The site was abandoned.

- Ok Ma tailings dam site-The proposed Ok Ma ("ok" translates as "river") tailings dam was intended to provide a retention reservoir for tailings from the Ok Tedi gold/copper mine in the Star Mountains of western Papua New Guinea. However, in December 1983, during construction of this conventional zoned earthfill/rockfill dam, a major, deep-seated landslide occurred in the weak mudstones and siltstones of the middle Miocene Pnyang Formation at its proposed left abutment (Fookes and others, 1991; Fookes and Dale, 1992; Fookes and others, 2000). Because no technically or economically feasible option was available for mitigation of the landslide or for shifting the axis of the tailings dam to a position off the landslide, the tailings dam site was abandoned.

\section{Redesign of Dams Because of Landslide Problems}

A few dams have been redesigned when a landslide was discovered in the foundation or an abutment. Excellent examples are Selevir Dam in western Turkey and Sweasey Dam, California, United States.

- Selevir Dam-Selevir Dam is a 31-m-high earthfill, irrigation dam in western Turkey. During construction, movement occurred in schist that forms the right abutment. As a result, (1) the outlet tunnel was redesigned and rerouted, (2) the outlet portal excavation, which had caused the slide, was refilled with recompacted material (that is, the fill became a buttress berm), (3) the intake structure was moved $455 \mathrm{~m}$ upstream, and (4) the original cutoff trench was replaced by a concrete cutoff wall with piles extending to schist bedrock (Sezginer and Karacaoğlu, 1961).

- Sweasey Dam-Sweasey Dam, on the Mad River in northern California, was originally designed to be a 40-45 m high concrete arch municipal water-supply dam. During construction, however, a slide occurred in Franciscan Complex sandstones and clayey shales of the left abutment (Kiersch and James, 1991). As a

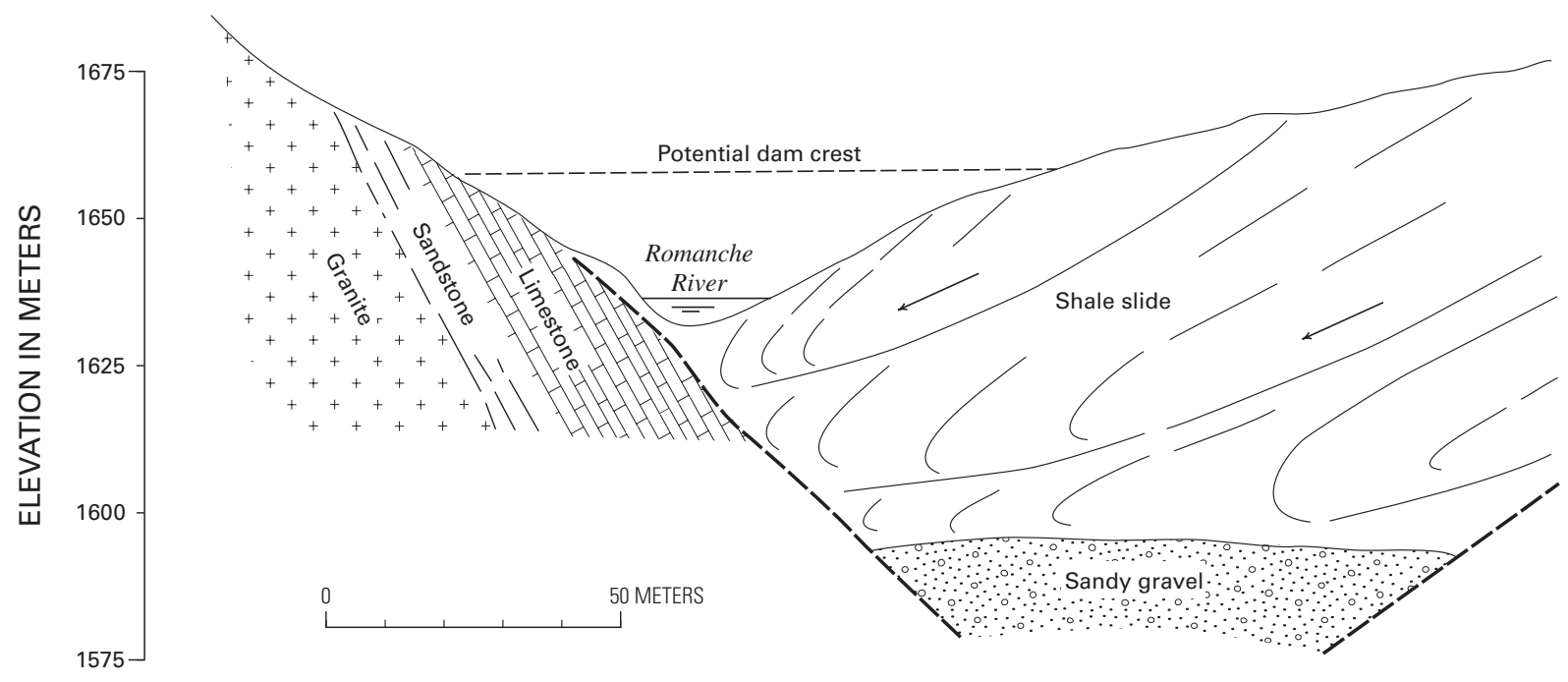

Figure 39. Cross section through a narrowed section of the Romanche River valley, France, showing the shale landslide that constricted the valley. Plans to construct a dam at this site were abandoned because of the landslide. Modified from Gignoux and Barbier (1955, p. 88). 
result, the dam was redesigned from a full concrete arch to a composite section employing an arch dam across the channel section, which abutted a massive concrete thrust block at the left end. An earthfill section then connected the thrust block with the excavated left abutment. Design height was also reduced by 20 $\mathrm{m}$ to an as-constructed 23-m height. During the 1970s, the dam was purposely breached because of excessive sedimentation in the reservoir (no relation to the landslide).

As noted earlier, embankment dams are more flexible than concrete structures, and thus can be built on pre-existing landslides with less risk of stability problems than is the case for concrete, and particularly concrete-arch, structures. Three dams in Appendix table A that were changed from concrete to rockfill during the preliminary design process because of pre-existing landslides in their footprints are Iril-Emda Dam (Algeria), Kangaroo Creek (Australia), and Pandoh Dam (India).

\section{Lowering Reservoir Level or Reducing Rate of Filling}

Although use of these procedures tends to impair the function of the dam, they constitute an effective means of increasing abutment stability by reducing abutment pore pressures and reducing seepage through the abutment by lowering the head or reducing its rate of increase. Five cases of reservoir lowering or reduction of rate of filling have been noted in this study:

- Casanuova Dam (central Italy)—Filling of the reservoir was temporarily suspended pending installation of additional remedial measures (Catalano and others, 2000).

- Rossella Dam (Island of Sicily, Italy)—Reservoir level was lowered to counter reactivation of a left-abutment earthflow (Catalano and others, 2000).

- Los Naranjos Dam (Mexico)—Release from the reservoir was controlled as one of several mitigative measures to slow reactivation of a 2 -million- $\mathrm{m}^{3}$ slide in the right abutment (Ramirez Reynaga, 1998).

- Rio Grande Dam (Colorado, United States) - For several years in the 1990s, Rio Grande Dam (fig. 1) operated at lowered reservoir level mandated by the State of Colorado because of left-abutment seepage through the toe of a pre-existing rock slide. The problem was solved by installation of the following remedial measures at the left abutment: (1) retaining wall, (2) french drains, and (3) horizontal drains. After completion of the remedial measures, reservoir level was allowed to be raised.
- Sam's Valley Dam (Oregon, United States)—Operation at a temporarily lowered reservoir level has been mandated by the State of Oregon because of excessive seepage through the landslide right abutment.

\section{Physical Measures for Foundation and Abutment Stabilization}

Da Costa Nunes and others (1982) have noted several physical mitigative measures for stabilization of abutments that are threatened by landslides. These stabilization methods include removal of landslide deposits; flattening the abutment slope; construction of earthfill or rockfill berms that serve as buttresses; construction of cutoffs or keys, retaining walls, piles or caissons, and anchors; moving or reinforcing the spillway; guniting; and "dental work."

\section{Removal of Landslide Deposits}

For cases in which a decision has been made to proceed with construction of a dam at the site of an old landslide, removal of all or part of the landslide material has often been accomplished as a successful preventive measure. There are 47 cases in Appendix table A in which part of the landslide deposit has been removed, but the remainder is included in the foundation or as part of an abutment in contact with the dam. Some examples of dams from which all or part of the landslide deposit has been removed are briefly mentioned below. The dams for which the landslide deposit has been totally removed have not been included in Appendix table A.

\section{Total Removal of Landslide}

Examples of total removal of landslide material that would have interacted with a dam or its appurtenant structures include the following dams (not included in Appendix table A): Little Para (Australia) (Beal, 1975), Ouchi (Japan) (Mikuni, 1980; Watanabe, 1985), Bell Canyon (California, United States) (Connell and others, 1985), Los Vaqueros (California) (Simpson and Schmoll, 2001), Dillon (Colorado, United States) (Wahlstrom and Nichols, 1969), Kinzua (Pennsylvania, United States) (Philbrick, 1976), and Tioga (Pennsylvania, United States) (Wilshusen and Wilson, 1981). In most such cases, all or part of the removed material was used to construct a berm, which served as a buttress.

\section{Partial Removal of Landslide}

Removal of part of the landslide took place in 47 of the dams listed in Appendix table A; well-documented examples include Kangaroo Creek (Australia), Thomson (Australia), 
Gardiner (Canada), Slezka Harta (Czech Republic), Bort (France), Evinos (Greece), Kassa (Japan), Ouchi (Japan), d'Aït Youb (Morocco), Arenós (Spain), Cortes de Pallás (Spain), Broomhead (United Kingdom), Austrian (California, United States), Castaic (California), Hernandez (California), San Dimas (California), Black Lake No. 1 (Colorado, United States), and Silver Jack (Colorado).

\section{Partial Removal of Talus Cover}

Removal of part of talus cover from an abutment commonly consists of placing a wide cutoff trench through the talus into bedrock, but may involve stripping of a larger area to bedrock. There are 14 such cases in Appendix table A: Parangana (Australia) (fig. 22), Eberlaste (Austria), Gepatsch (Austria), Euclides de Cunha (Brazil), Serre-Ponçon (France), Ancipa (Italy), Ozola (Italy), Francisco Zarco (Mexico), Vicente Guerrero (Mexico), Wemmershoek (South Africa), Marmorera (Switzerland), Taylor Park (Colorado, United States) (fig. 4), Anderson Ranch (Idaho, United States), and Joes Valley (Utah, United States).

\section{Partial Removal of Landslide Deposit Following Construction or Postconstruction Slope Failure}

Partial removal of landslide materials during construction or postconstruction slope failure took place at 65 of the dams in Appendix table A; examples of these include Quebrada de Ullum (Argentina), Gardiner (Canada), Slezska Harta (Czech Republic), Daniel Palacios (Ecuador), Chaudanne (France), Los Naranjos (Mexico), Tresna (Poland), Arenós (Spain), Broomhead (United Kingdom), Castaic (California, United States), Trinity (California), Ridgway (Colorado, United States), Silver Jack (Colorado), Lovewell (Kansas, United States), Agate (Oregon, United States), Lookout Point (Oregon), Oahe (South Dakota, United States), Joes Valley (Utah, United States), and Grand Coulee (Washington, United States).

\section{Flattening Abutment Slopes}

Flattening of abutment slopes (unloading the upper part of the landslide) has been used as a preventive/remedial measure on 15 of the dams listed in Appendix table A. These are Quebrada de Ullum (Argentina), Gardiner (Canada), Dalešice (Czech Republic), Nechranice (Czech Republic), Slezska Harta (Czech Republic), Ranaptrap Sagar (India), Los Naranjos (Mexico), Cortes de Pallás (Spain), Devil's Dingle (United Kingdom), Castaic (California, United States), San Dimas (California, United States), Silver Jack (Colorado, United States), Agate (Oregon, United States), Oahe (South Dakota, United States), and Grand Coulee (Washington, United States).

\section{Earthfill or Rockfill Berms Serving as Buttresses}

Earthfill and rockfill berms often have been used as buttresses to increase the stability of abutment slopes. If these berms include fine-grained materials, they may also reduce seepage at the toe of the dam. In many cases, the material for construction of berms is obtained directly from landslide deposits excavated from upslope areas along or near the abutment. Thirty-nine examples of construction of berms as abutment-slope buttresses are presented in Appendix table A. Some of the more interesting examples and the types of berms installed include the following:

- Thomson Dam (Australia)-2.6-million-m³ rockfill berm

- Eberlaste Dam (Austria)—50-m-wide stabilizing fill that served as berm

- Dalešice Dam (Czech Republic) (fig. 10)—150,000-m³ rockfill berm

- Mornos Dam (Greece) -8-million-m ${ }^{3}$ toe berm placed along the reservoir shore immediately upstream from dam

- Tablachaca Dam (Peru) - 467,000- $\mathrm{m}^{3}$ toe berm placed in the reservoir immediately upstream from dam 10 years after original construction

- Liptovaská Mara Dam (Slovakia)—700,000-m³ sand/ gravel berm

- Cortes de Pallás Dam (Spain)—800,000 m³ excavated from upper part of slide and moved to lower part to form toe berm

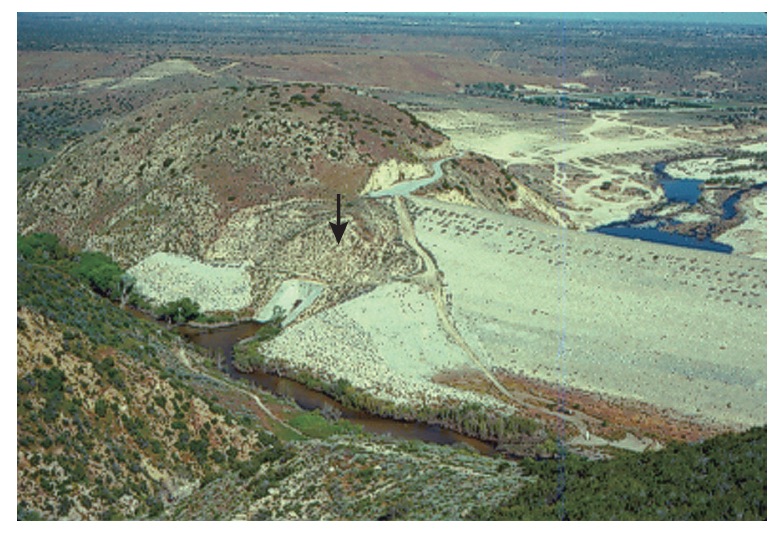

Figure 40. Oblique view of the left end of Mojave River Dam, an earthfill flood-control structure in southern California, United States, showing the two earth berms that were added to the left abutment to buttress a small abutment slide (marked by arrow) that occurred during construction. Photograph taken in 1998. 
- B.F. Sisk (San Luis) Dam (California, United States)_Addition of an upstream toe berm (fig. 32) was necessitated by a postconstruction slide in left abutment

- Mojave River Dam (California, United States)-Two earthfill berms serve as buttresses (fig. 40)

- Terminal Dam (California, United States) -6.5-m-high upstream and downstream berms

- Silver Jack Dam (Colorado, United States) - 87,000-m³ toe berm obtained from slope above abutment

- Lake Harriet Dam (Oregon, United States)_-Berm with an impervious bentonitic membrane was placed against upstream face of the concrete-arch dam, mainly to reduce seepage (fig. 14)

- Oahe Dam (South Dakota, United States) -3.5-million- $\mathrm{m}^{3}$ construction-caused slide in left abutment was excavated and material was placed as a berm that serves as toe buttress

\section{Dam Serving as Buttress}

Often, potential abutment slides have been successfully buttressed by the mass of the dam itself. In this manner, the abutment slopes may be more stable than before the dam was built. However, the existence of the dam will have little effect on seepage through the abutment. All dams have a buttressing effect; some examples from Appendix table A, where this effect has been specifically noted, include Iril-Emda (Algeria), Mornos (Greece), Pandoh (India), Clyde (New Zealand), Trinity (California, United States), Gross (Colorado, United States) (figs. 5 and 6), Ridgway (Colorado), Lovewell (Kansas, United States), Conchas (New Mexico, United States), Oahe (South Dakota, United States), Calder (Utah, United States), Jordanelle (Utah), Red Creek (Utah), and Yale (Washington, United States).

\section{Cutoffs or Keys}

An impervious cutoff (usually concrete) is often placed in a trench that is excavated beneath the location of the dam core. The main function of a cutoff usually is to reduce seepage through the foundation or abutment. However, these cutoffs also "key" the dam into the foundation or abutment, and thus increase stability in addition to reducing permeability. Some examples of dams with cutoffs are given in the following section on reducing seepage.

An instance of the reinforcement of a landslide abutment using a concrete mass is San Jacinto Dam (Bolivia), where the left abutment was strengthened by filling adits with concrete (Riemer, 1995).

\section{Retaining Walls}

Conventional retaining structures occasionally have been used to increase abutment stability during construction. These walls commonly are left in place and become part of the dam. Dams in Appendix table A in which retaining walls were used to increase abutment stability include Zardezas (Algeria), Ichari (India), Jaldhaka Stage I (India), Ranaptrap Sagar (India), Tresna (Poland), Brooktrails No. 3 North (California, United States), Rio Grande (Colorado, United States) (fig. 1), Conchas (New Mexico, United States), and Grand Coulee (Washington, United States) (fig. 21).

\section{Piles and Caissons}

Dams from Appendix table A in which piles or caissons have been used to increase lateral stability include Wuping (China, vertical rock piles), Pong (India, concrete caissons), Bass Lake (Montana, United States, sheet piling), Madison (Montana, steel piling), Swift (Washington, United States, sheetpiling), and McElroy's Run (West Virginia, United States, augercast grout columns).

\section{Anchors}

Anchors (usually prestressed steel) are often used to increase the stability of rock abutments, particularly during construction. Included in Appendix table A are the following dams that have successfully utilized anchors in abutments: Meishan (China), Dalešice (Czech Republic) (fig. 10), Daniel Palacios (Ecuador), Chaudanne (France), Ranaptrap (India), Kawamata (Japan), Santa Rosa (Mexico), Tablachaca (Peru), Tresna (Poland), Pacoima (California, United States), and San Dimas (California).

\section{Moving or Reinforcing Spillway}

In a few cases, either the main or the emergency spillway has been known to leak water into or cause erosion of a landslide abutment. In these cases, the spillway has either been moved to the other end of the dam or has been sealed or reinforced to prevent leakage or erosion. Examples of such cases in Appendix table A include the following:

- Trinità Dam (Island of Sicily, Italy)—The spillway, which was located on a pre-existing earth flow-earth slide, was founded on a system of piles to protect it from movement (Catalano and others, 2000).

- Austrian Dam (California, United States)—The spillway was relocated (partially to protect the spillway and partially to help stabilize the landslide abutment). 
- Star Mountain Dam (Oregon, United States)-A circular concrete-lined emergency spillway replaced an earlier unlined spillway that had failed due to flood erosion, thus causing failure of the landslide abutment, and then failure of the dam (fig. 35).

\section{Guniting}

Although guniting provides almost no direct structural strength, it is occasionally used to increase the stability of a very steep slope by inhibiting surface erosion. The only dams in Appendix table A with abutment slopes that are protected by gunite are Santa Rosa (Mexico) and Pacoima (California, United States).

\section{“Dental Work"}

"Dental work" is the filling of joints and other voids with cement grout or concrete to increase local stability and possibly to reduce permeability. It is often used on rock abutments during construction. The only Appendix table A dams for which dental work has been carried out on a rock abutment to reduce the landslide hazard during excavation are Tooma (Australia), Daule Peripa, (Ecuador), Los Naranjos (Mexico), and Jordanelle (Utah, United States).

\section{Physical Measures for Reducing Abutment and Foundation Seepage}

\section{Impervious Cutoffs}

Probably the most common seepage-reduction measures are impervious cutoffs that are constructed through the landslide materials to solid rock. Usually, these cutoffs are made of Portland-cement concrete and serve as vertical "keys" in zone 1 of the dams to increase stability of the structure in addition to reducing seepage; however, some are impervioussoil or bentonitic-slurry cutoffs, which do little or nothing to increase stability. Cutoffs are commonly installed during the construction process. Dams in which concrete cutoffs have been installed during construction to prevent seepage include O'Shannassay (Australia), Eberlaste (Austria, asphaltic concrete), Freibach (Austria), Ichari (India), Pandoh (India), Salal (India), Ancipa (Italy), Ozola (Italy), Pian Palù (Italy), Vodo (Italy), Rules (Spain), Marmorera (Switzerland), Selevir (Turkey), and Woodhead No. 2 (United Kingdom). Flexible slurry-trench or clay cutoffs were installed at Eberlaste Dam (Austria, slurry trench), Euclides da Cunha (Brazil, "impervious soil"), Nechranice (Czech Republic, "clay-cement"), Francisco Zarco Dam (Mexico, slurry trench), and Vicente Guerrero (Mexico, impervious clay). Cases in which a cutoff was added when seepage problems were encountered during operation include Site 19 (New York, United States), Long Park (Utah, United States), and Mud Mountain (Washington, United States).

\section{Impervious Curtains, Membranes, and Blankets}

Seepage can also be intercepted and diverted by impervious curtains, membranes, or blankets that have little inherent structural strength, for example, cement or chemical grout curtains, plastic or geosynthetic membranes, and clay blankets. Thirty-seven dams from Appendix table A include grout curtains in their foundations and/or abutments. Fourteen of the dams in Appendix table A include impervious membranes or clay blankets. These measures are not intended to act as strengthening "keys" through the landslide material to bedrock, but may increase stability as well as reduce seepage by locally lowering pore pressures in the foundation and abutments. Dams in which these measures have been used include the following:

- Grouting (during construction)—Quebrada de Ullum (Argentina), Parangana (Australia), Tooma (Australia), Durlassboden (Austria), Euclides da Cunha (Brazil), Polemidhia (Cyprus), Terlicko (Czechoslovakia), Chaudanne (France), Ranaptrap Sagar (India), Salal (India), Beauregard (Italy), Kassa (Japan), Terayama (Japan), Francisco Zarco (Mexico), Marmorera (Switzerland), Castaic (California, United States), San Dimas (California), Black Lake No. 1 (Colorado, United States), El Vado (New Mexico, United States), and Moon Lake (Utah, United States)

- Grouting (after seepage or movement developed)Freibach (Austria), Yeso (Chile), Meishan (China), Los Naranjos (Mexico), Nakhla (Morocco), Arnensee (Switzerland), Broomhead (United Kingdom), Austrian (California, United States), Pacoima (California), Clear Lake (Colorado, United States), Scholl (Colorado), Young's Creek Nos. 1 and 2 (Colorado), Bull Run No. 2 (Oregon, United States), and Waterbury (Vermont, United States)

- Impervious membranes or clay blankets (during construction) - Seymour Falls (Canada), Ranaptrap Sagar (India), Salal (India), Terayama (Japan), and South Creek (Utah, United States)

- Impervious membranes or clay blankets (after seepage or movement had occurred)-Meishan (China), Beaver (Colorado, United States), Cedar Mesa (Colorado), Matheson (Colorado), Scholl (Colorado), Young's Creek Nos. 1 and 2 (Colorado), Black Lake (Montana, United States), Hyalite (Montana), and Stemilt Main (Washington, USA) 
Note the relatively large number of dams in the Western United States that have been repaired by installation of grout curtains or impervious membranes after the occurrence of seepage. This is indicative of the seriousness of seepage problems faced by dams that have been built on landslides.

\section{Drainage Systems}

Drainage systems are commonly used to intercept water before it enters the landslide deposit or to remove water from the landslide material. Drainage helps to stabilize abutment landslide materials, to control seepage through the abutment or foundation, and to reduce the possibility of piping. Thirty-four dams in Appendix table A have been improved by installation of drainage systems. These systems commonly consist of one or more of the following: surface drainage, interceptor trench drains (vertical trenches backfilled with pervious materials, such as sand and gravel), "horizontal" drains, adits and galleries, filter blankets, and pumping wells. Toe drains and relief wells also are used to allow water to exit without building up pore pressures within the abutment or foundation materials. Any of these measures may be installed during dam construction as preventive measures, or may be added later as remedial measures.

Examples of dams in Appendix table A for which drainage systems were added either during or after construction include the

following:

- Surface drains-Slezska Harta (Czech Republic), Polyphyton (Greece), Wemmershoek (South Africa), Currier \#2 (Colorado, United States), Silver Jack (Colorado), and Nevada Creek (Montana, United States)

- Trench drains-Broomhead (United Kingdom), Brooktrails No. 3 North (California, United States), Kiser Slough (Colorado, United States), Rio Grande (Colorado), and Bumping Lake (Washington, United States)

- Horizontal drains-Pandoh (India), Tablachaca (Peru), Rio Grande (Colorado, United States), Silver Jack (Colorado), South Creek (Utah, United States), and Howard Hanson (Washington, United States)

- Adits, tunnels, and galleries-Polyphyton (Greece), Nakhla (Morocco), Tablachaca (Peru), City of Portland No. 3 (Oregon, United States), and Howard Hanson (Washington, United States)

- Filter blankets-Wungong (Australia) and Howard Hansen (Washington, United States)

- Pumping wells-Evinos (Greece)
- Toe drains and relief wells-Quebrada de Ullum (Argentina), Engenheiro Avidos (Brazil), saddle dam for F. Mohamed B.A. el Khattabi (Morocco), Jones \#2 (Colorado, United States), Overland \#1 (Colorado), and Howard Hanson (Washington, United States)

\section{Multiple Mitigation Methods}

All of the above preventive and remedial measures have been known to increase stability and/or reduce seepage, and, in some cases, they have been completely successful. However, in most successful cases more than one method has been utilized.

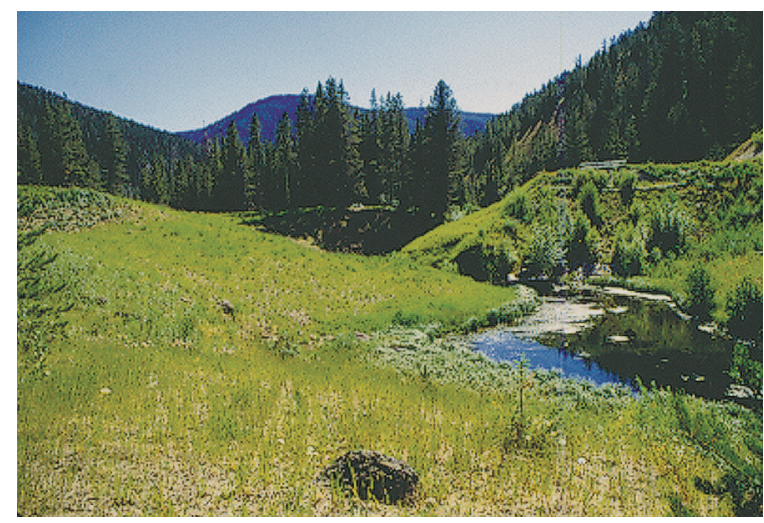

Figure 41. The remains of Mystic Lake Dam, a small water-supply dam in southwestern Montana, United States, which was constructed in 1903-04 on the site of a landslide dam. The earthfill dam was purposely breached in 1984 because of the hazard it posed to the downstream city of Bozeman. Photograph taken in 1997.

\section{Breaching as a "Remedy"}

The only dams that I know of that have been purposely breached because of the downstream hazard that they posed due to a landslide are Mystic Lake Dam, a 13-m-high, earthfill water-supply dam for the city of Bozeman, Montana, United States, and Site 19 Dam, a 20-m-high flood-control dam in New York State, United States.

- Mystic Lake Dam-Mystic Lake Dam (fig. 41), which was constructed in 1903-04 on the site of a "recent" (about $100 \mathrm{yr}$ old) landslide dam, leaked excessively throughout its lifetime, and was in possible danger of failure due to piping. Thus, it was purposely breached in 1984 in response to the U.S. Dam Safety Program (High Country Independent Press, 1985). 
- Site 19 Dam-Site 19 Dam, which was constructed in 1971, was breached in 1980 because of excessive leakage in the left abutment due to a pre-existing ancient slump (Kirkaldie and Thomas, 1984; Kiersch and James, 1991). The dam was redesigned and rebuilt with remedial measures consisting of (1) a cutoff trench to bedrock and into the embankment and (2) an enlarged foundation drainage system.

\section{Summary and Conclusions}

Geologists sometimes feel that it is impossible to safely construct a dam on a pre-existing landslide. Conversely, some engineers have been known to assume that today's advanced construction and prevention techniques can overcome any landslide problem. This study of 254 dams that either have been built on pre-existing landslides or were subjected to landslides during or after construction shows that reality is somewhere in between these extremes. Some dams have been built on landslides with no ensuing difficulties, even in cases where preventive measures were not used; others have encountered serious seepage or stability problems, most of which have been at least partly alleviated by installation of remedial measures, such as berms, cutoff walls, drainage systems, grouting, or impervious membranes. However, avoidance of sites where landslides may result in exorbitant costs during construction or remediation should always be considered as a serious option.

This study has noted many cases in which dams built on landslides have operated for many years without major stability or seepage problems. In only four cases, Cheurfas Dam (Algeria) [not included in Appendix table A], Euclides da Cunha Dam (Brazil), St. Francis Dam (California, United States), and Star Mountain Dam (Oregon, United States), can failure (that is, natural breaching) of a dam be considered to have been related to problems caused by pre-existing landslides. Only in the case of the failure of St. Francis Dam was the failure catastrophic in terms of loss of life. Mystic Lake Dam (fig. 39) and Site 19 Dam were the only cases found in which a dam was intentionally breached because of concerns that major landslide-related failure was probable.

This survey indicates that seepage through an abutment has been the most common negative result of building a dam on a landslide. Seepage occurs through open joints and failure surfaces in rock and earth landslides, and through voids in more pervious landslide masses, such as rock falls and debris flows. When carried to the extreme, seepage could possibly lead to piping (particularly in loose granular materials) and possible dam failure; however, we found no case in which this has occurred as a result of a dam having been constructed on a landslide. More commonly, seepage has resulted in loss of water intended for irrigation or power production, thus resulting in project inefficiency and economic loss.
There seems to be no clear indication as to which landslide types perform best or worst when used as an abutment or a foundation. In most cases, all landslide types have proven to be fairly stable, although slides in shales appear to perform the poorest. In contrast, all landslide types seem to be subject to possible seepage problems unless proper preventive or remedial measures are taken. In general, rock-fall deposits (such as talus) are pervious, and thus provide ready paths for seepage; however, some talus deposits include enough fine material to be relatively impervious. Thus, in regard to both stability and seepage, the physical characteristics of the individual landslides and the physical properties of the landslide materials should be carefully considered in the siting process for any dam in which a landslide will be part of an abutment or the foundation. Of particular importance in regard to seepage is the permeability of the landslide mass.

\section{Acknowledgments}

I would like to thank my many professional colleagues around the world who helped me by providing ideas and case histories for this study.

In the United States, special thanks go to the various State dam-safety agencies and Federal dam-building and damregulating agencies, who allowed ready access to their files on dams that have been built on landslides. The same degree of cooperation was extended by companies, irrigation districts, city water departments, and private parties, who own the dams.

Thanks also go to CAMBIOR (Canada) and Geotecnica Consultores (Chile), who provided funding for the early stages of the study, an expenditure that ensured its success.

I would also like to note the day-to-day help I received from colleagues in the U.S. Geological Survey, the U.S. Bureau of Reclamation, and the U.S. Army Corps of Engineers, as well as the services of the excellent technical libraries of these agencies.

\section{References Cited}

Agnew, A.F., 1985, Dissecting a dam: Bulletin of the Association of Engineering Geologists, v. 22, no. 4, p. 458.

Ajabi, A., Amrane, K, and Ezzitouni, M., 1991, Cheurfas II - construction d'un barrage-poids en béton conventionnel sur foundations médiocres, in Transactions: 17th International Congress on Large Dams, International Commission on Large Dams, Vienna, June 17-21, v. 3, p. 1,313-1,339. 
Alberro, J., 1976, Filtrations in the foundations of Santa Rosa Dam, in Transactions: 12th International Congress on Large Dams, International Commission on Large Dams, Mexico City, March-April, v. 2, p. 299-311.

Alonso, E.E., Gens, A., and Lloret, A., 1993, The landslide of Cortes de Pallas, Spain: Géotechnique, v. 43, no. 4, p. 507-521.

Amundson, C.T., and Scofield, D.H., 1998, Engineering geology of Elk Creek Dam, Jackson County, Oregon, in Burns, S., ed., Environmental, groundwater and engineering geology - applications from Oregon: Belmont, Calif., Star Publishing Company, p. 133-142.

Anderson, J.G.C., and Trigg, C.F., 1976, Case histories in engineering geology: London, Elek Science, 204 p.

ANIDEL, 1952, Dams for hydroelectric power in Italy: Associazione Nazionale Imprese Produttrici e Distributrici di Energia Elettrica, Rome, v. 2, 272 p. plus figures, v. 4, 302 p. plus figures, v. 5, 234 p. plus figures.

ANIDEL, 1953, Dams for hydroelectric power in Italy: Associazione Nazionale Imprese Produttrici e Distributrici di Energia Elettrica, Rome, v. 3, 253 p. plus figures, v. 6, 271 p. plus figures, v. 7, 257 p. plus figures.

ANIDEL, 1961, Dams for hydroelectric power in Italy: Associazione Nazionale Imprese Produttrici e Distributrici di Energia Elettrica, Rome, v. 1, 959 p.

Andreu, F.J., Martinez-Alegria, R., and Utrillas, J.L., 1988, Analisis de estabilidad y estudio de reacondicionamiento de una ladera en la margen izquierda del Rio Mijares (Castellon), in Proceedings: 2d Simposio sobre Taludes y Laderas Inestables, Andorra la Vella, March, p. 295-309.

Atwood, W.W., 1918, Relation of landslides and glacial deposits to reservoir sites: U.S. Geological Survey Bulletin 685, $38 \mathrm{p}$.

Atwood, W.W., and Mather, K.F., 1932, Physiography and Quaternary geology of the San Juan Mountains, Colorado: U.S. Geological Survey Professional Paper 166, 176 p.

Austrian National Committee on Large Dams, 1991, Dams in Austria: Vienna, 331 p.

Barbier, R., 1974, La géologie au service des grands travaux, in Proceedings: Colloquim, Géologie de L'Ingénieur, Société Géologique de Belgique, Liége, September, p. 77-111.
Barclay, C.S.V., 1968, Geology of the Gore Canyon-Kremmling Area, Grand County, Colorado: U.S. Geological Survey Open-File Report, 187 p.

Baum, R.L., and Odum, J.K., 1996, Geologic map of slumpblock deposits in part of Grand Mesa area, Delta and Mesa Counties, Colorado: U.S. Geological Survey Open-File Report 96-017, 12 p. plus map, scale 1:24,000.

Baum, R.L., and Odum, J.K., 2003, Retrogressive slumping at Grand Mesa, Colorado, in Boyer, D.D., Santi, P.M., and Rogers, W.P., eds., Engineering geology in Colorado-contributions, trends, and case histories: Association of Engineering Geologists Special Publication 14 and Colorado Geological Survey Special Publication (CD-ROM).

Beaulieu, J.J.D., 1974, Geologic hazards of the Bull Run Watershed, Multnomah and Clackamas Counties, Oregon: Oregon Department of Geology and Mineral Industries Bulletin 82, 77 p.

Beal, J.C., 1975, Engineering geology of the Little Para damsite, in Proceedings: 2d Australia-New Zealand Conference on Geomechanics, Brisbane, July 21-25, p. 207-212.

Beene, R.R.W., 1967, Waco Dam slide: Journal of the Soil Mechanics and Foundations Division, American Society of Civil Engineers, v. 93, no. SM4, July, p. 35-44.

Benson, S., and Pate, K., 1998, Dams of the Lower Deschutes River-Round Butte, Pelton Arch, and Pelton Regulating Dams, in Burns, S., ed., Environmental, groundwater, and engineering geology_applications from Oregon: Belmont, Calif., Star Publishing Company, p. 45-58.

Bernton, H., 2000, Mount St. Helens debris still sullies Toutle River: Portland, Oreg., The Oregonian, 16 January.

Bhatnagar, P.S., and Parkash, V.A., 1967, Stability of excavated slopes around intake areas-Beas Dam at Pong, India, in Transactions: 9th International Congress on Large Dams, International Commission on Large Dams, Istanbul, September 4-8, v. 1, p. 1,051-1,067.

Bliton, W.S., 1989, Lewis River projects, in Galster, R.W., ed., Engineering geology in Washington: Washington Division of Geology and Earth Resources, v. 1, p. 277-298.

Bock, R.W., and Harber, W.G., 1974, Problems encountered in construction of dam foundations, in Foundations for dams: Proceedings, Engineering Foundation Conference, sponsored by the Geotechnical Engineering Division, American Society of Civil Engineers, and U.S. Committee on Large Dams, Asilomar, Calif., March, p. 87-113. 
Bosler, J.C., Gratwick, C., Beattie, N., and Maso, S., 1991, Earthfill dam on a foundation of fissured clay containing an old slide surface, in Transactions: 17th International Congress on Large Dams, International Commission on Large Dams, Vienna, June 17-21, v. 3, p. 1,555-1,575.

Boufous, L., and Benzekri, J., 1985, Étude des problèmes d'infiltration a l'aval de la digue F du barrage De Mohamed Ben Abdelkrim el Khattabi sur L'Oued Neckor, in Transactions: 15th International Congress on Large Dams, International Commission on Large Dams, Lausanne, v. 3, p. 947-963.

Bowen, R., 1984, Geology in engineering: London, Elsevier Applied Science Publishers, 411 p.

Bravo, G., 1967, La fondation du barrage de Iznajar, in Transactions: 9th International Congress on Large Dams, International Commission on Large Dams, Istanbul, September 4-8, v. 1, p. 573-582.

Brazilian Committee on Large Dams, 1982, Technical data about Euclides da Cunha Dam, in ICOLD Publications Committee, eds., Main Brazilian dams-design, construction and performance: published for 14th International Congress on Large Dams, International Commission on Large Dams, Rio de Janeiro, p. 411-435.

Brink, A.B.A., 1981, Engineering geology of Southern Africa: Pretoria, Building Publications, v. 2, 255 p.

Bromehead, C.E.N., 1936, Geology of reservoir-damsites, in Transactions: 2nd International Congress on Large Dams, International Commission on Large Dams, Washington, D.C., v. 4, p. 113-119.

Brown, R., Gillon, M., and Deere, D., 1993, Landslide stabilization at the Clyde Power Project, New Zealand, in Anderson, L.R., ed., Geotechnical practice in dam rehabilitation: American Society of Civil Engineers Geotechnical Special Publication 35, p. 299-319.

Bryant, B., 1990, Geologic map of the Salt Lake City 30' $\times 60^{\prime}$ quadrangle, north-central, Utah, and Uinta County, Wyoming: U.S. Geological Survey Miscellaneous Investigations Map I-1944, scale 1:100,000.

Bujak, M., Glab, W., Moraczewski, K., and Wolski, W., 1967, Preventive measures against the rock slide at Tresna Dam site, in Transactions: 9th International Congress on Large Dams, International Commission on Large Dams, Istanbul, September 4-8, v. 1, p. 1,027-1,036.
Burwell, E.B., Jr., and Moneymaker, B.C., 1950, Geology in dam construction, in Paige, S., ed., Application of geology to engineering practice-Berkey Volume: Geological Society of America, p. 11-43.

Bzioui, M., and Chraibi, A.F., 1991, Barrage d'Aït Youb adaptation du projet aux conditions géologiques réelles de la fondation, in Transactions: 17th International Congress on Large Dams, International Commission on Large Dams, Vienna, June 17-21, v. 3, p. 601-612.

Cabanius, J., and Maigre, R., 1958, The Durance development-the Serre-Ponçon dam-Travaux: 6th International Congress on Large Dams, International Commission on Large Dams, August, no. 286, p. 43-60.

Carrara, P.E., 1990, Surficial geologic map of Glacier National Park, Montana: U.S. Geological Survey Miscellaneous Investigations Series Map I-1508-D, scale 1:100,000.

Carter, B.H., 1998a, Ochoco Dam, Crook County, central Oregon, in Burns, S., ed., Environmental, groundwater and engineering geology - applications from Oregon: Belmont, Calif., Star Publishing Company, p. 59-67.

Carter, B.H., 1998b, Safety of dams modifications to Ochoco Dam, Crooked River project, Oregon, in Proceedings: 33rd Symposium on Engineering Geology and Soils Engineering, Reno, Nev., March, p. 25-36.

Castelucci, P., Coli, M., and Lazzeri, D., 1999, Studio geostrutturale-geomeccanico dell spalla destra della diga di Riolunato (Appennino Modenese): Geologia e Geotecnica Ambientale, v. 36, no. 2-3, p. 99-105.

Castilla, J.E., and Colina, P., 1985, Santa Rosa arch dam, reinforcement of the left bank, in Transactions: 15th International Congress on Large Dams, International Commission on Large Dams, Lausanne, June 24-28, v. 4, p. 843-862.

Castro, F., and Garces, E., 1985, Cement-bentonite cutoff for reconditioning Bullileo earth dam, in Transactions: 15th International Congress on Large Dams, International Commission on Large Dams, Lausanne, June 24-28, v. 4, p. 619-632.

Catalano, A., Chieppa, V., and Russo, C., 2000, Interaction between dams and landslides - three case histories, in Bromhead, E., Dixon, N., and Ibsen, M-L., eds., Landslides in research, theory and practice: London, Thomas Telford, Proceedings, 8th International Symposium on Landslides, Cardiff, Wales, June 26-30, v. 1, p. 227-232. 
Cavallin, J.E., 1991, Terminal Dam, design and construction of an earthfill dam on a soft foundation, in Transactions: 17th International Congress on Large Dams, International Commission on Large Dams, Vienna, June 17-21, v. 3, p. $1,179-1,198$.

Central Board of Irrigation and Power, 1979, Beas Dam at Pong, in Design and construction features of selected dams in India: Indian National Commission of the International Commission on Large Dams, New Delhi, Publication 138, p. 183-235.

Chandler, R.J., 1976, The history and stability of two Lias clay slopes in the upper Gwash valley, Rutland: Philosophical Transactions Royal Society of London, series A, v. 283, p. 463-491.

Chatterjee, B., 1979, Geotechnical problems in planning and execution of an hydro-electric project in Darjeeling Himalaya: International Association of Engineering Geology Bulletin, no. 20, p. 73-77.

Chen, L., Zhang, T., Lin, T., Zhou, X., and Chen, Z., 2001, Consolidation and stability behavior of a high rockfill dam built on soft clay foundation, in Proceedings: 3rd International Conference on Soft Soil Engineering, Hong Kong, December, p. 175-180.

Chinese National Committee on Large Dams, eds., 1987, Large dams in China-history, achievement, prospect: Beijing, China Water Resources and Electric Power Press, 249 p.

Cifres, E., 1998, New spillway for $105 \mathrm{~m}$ high rockfill dam, in order to update hydrologic and geotechnical safety-case of Arenós Dam, Spain, in Berga, L., ed., Dam safety: Proceedings, International Symposium on New Trends and Guidelines on Dam Safety, Barcelona, June 17-19, v. 2, p. 1,379-1,386.

Clarke, D.D., 1904, A phenomenal landslide: American Society of Civil Engineers Transactions, v. 53, no. 984, p. $321-412$.

Colton, R.B., Holligan, J.A., and Anderson, L.W., 1975a, Preliminary map of landslide deposits, Durango $1^{\circ} \times 2^{\circ}$ quadrangle, Colorado: U.S. Geological Survey Miscellaneous Field Studies Map MF-703, scale 1:250,000.

Colton, R.B., Holligan, J.A., and Anderson, L.W., 1975b, Preliminary map of landslide deposits, Greeley $1^{\circ} \times 2^{\circ}$ quadrangle, Colorado: U.S. Geological Survey Miscellaneous Field Studies Map MF-704, scale 1:250,000.
Colton, R.B., Holligan, J.A., Anderson, L.W., and Patterson, P.E., 1975c, Preliminary map of landslide deposits, Leadville $1^{\circ} \times 2^{\circ}$ quadrangle, Colorado: U.S. Geological Survey Miscellaneous Field Studies Map MF-701, scale 1:250,000.

Colton, R.B., Holligan, J.A., Anderson, L.W., and Shaver, K.C., 1975d, Preliminary map of landslide deposits, Moab $1^{\circ} \times 2^{\circ}$ quadrangle, Colorado: U.S. Geological Survey Miscellaneous Field Studies Map MF-698, scale 1:250,000.

Colton, R.B., Holligan, J.A., Anderson, L.W., and Whitney, J.W., 1975e, Preliminary map of landslide deposits, Grand Junction $1^{\circ} \times 2^{\circ}$ quadrangle, Colorado and Utah: U.S. Geological Survey Miscellaneous Field Studies Map MF-697, scale $1: 250,000$.

Colton, R.B., Holligan, J.A., Patterson, P.E., and Anderson, L.W., 1975f, Preliminary map of landslide deposits, Craig $1^{\circ} \mathrm{x} 2^{\circ}$ quadrangle, Colorado: U.S. Geological Survey Miscellaneous Field Studies Map MF 700, scale 1:250,000.

Colton, R.B., Patterson, P.E., Holligan, J.A., and Anderson, L.W., 1975g, Preliminary map of landslide deposits, Montrose $1^{\circ} \times 2^{\circ}$ quadrangle, Colorado: U.S. Geological Survey Miscellaneous Field Studies Map MF-702, scale 1:250,000.

Comité Español de Grandes Presas, 1993, Arenós, in Selección de presas Españolas, 1973-1993: Ministerio de Obras Públicas, Transportes y Medio Ambiente, Madrid, p. 72-79.

Comité Français des Grandes Barrages, 1982, La reconnaissance des sites de barrage difficultés rencontrées, in Transactions: 14th International Congress on Large Dams, International Commission on Large Dams, Rio de Janeiro, May 3-7, v. 2, p. 877-891.

Comité National Suisse des Grandes Barrages, 1976, Rapport de synthèse, in Transactions: 15th International Congress on Large Dams, International Commission on Large Dams, Mexico City, March 29-April 2, v. 4, p. 495-532.

Committee on Failures and Accidents to Large Dams, 1976, Lessons from dam incidents USA: New York, United States Committee on Large Dams, American Society of Civil Engineers, p. 127-128.

Connell, D.H., Solomon, E., and Rodda, K.V., 1985, Grouting solves complex seepage problems at Bell Canyon Dam, in Transactions: 15th International Congress on Large Dams, International Commission on Large Dams, Lausanne, June 24-28, v. 3, p. 591-611.

Corda, I.I., 1988, Iron Gates II-design and performance of dams_-geotechnical considerations, in Proceedings: 2nd International Conference on Case Histories in Geotechnical Engineering, St. Louis, June 1-5, v. 1, p. 663-670. 
Cornforth, D.H., and Mikkelsen, P.E., 2000, Continuous monitoring of groundwater response to winter rainfall, in Bromhead, E., Dixon, N., and Ibsen, M-L., eds., Landslides in research, theory and practice: Thomas Telford, London, Proceedings, 8th International Symposium on Landslides, Cardiff, Wales, June 26-30, v. 1, p. 323-328.

Cotton, W.R., 1972, Preliminary geologic map of the Franciscan rocks in the central part of the Diablo Range, Santa Clara and Alameda Counties, California: U.S. Geological Survey Basic Data Contribution 39, scale 1:62,500.

Coyne, A., 1939, Cours de barrages à l'Ecole Nationale Supérieure des Ponts et Chaussees: Paris.

Crandell, D.R., 1951, Preliminary report on the geology of the Pierre quadrangle, South Dakota: U.S. Geological Survey Open-File Report, 28 p.

Crandell, D.R., 1952, Landslides and rapid-flowage phenomena near Pierre, South Dakota: Economic Geology, v. 47, p. $548-568$.

Crandell, D.R., 1958, Geology of the Pierre area, South Dakota: U.S. Geological Survey Professional Paper 307, $83 \mathrm{p}$.

Crosby, I.B., 1939, Engineering geology problems at Conchas Dam, New Mexico: American Society of Civil Engineers Proceedings, v. 65, January, p. 29-47.

Cruden, D.M., and Varnes, D.J., 1996, Landslide types and processes, in Turner, A.K., and Schuster, R.L., eds., Landslides-investigation and mitigation: Washington, D.C., National Academy Press, Transportation Research Board Special Report 247, p. 36-75.

Czechoslovak National Dam Committee, 1967, Dams in Czechoslovakia: Bratislava, 32 p.

da Costa Nunes, A.J., de M. Fernandez, C.E., Lima, A., 1982, Stabilization of dam abutments-Brazilian case histories, in Transactions: 14th International Congress on Large Dams, International Commission on Large Dams, Rio de Janeiro, May 3-7, v. 2, p. 859-876.

de la Torre, M., Garga, V., Novosad, S., Tordoya, J., and Mayta, J., 1997, Revaluación de la estabilidad del Derrumbe no. 5-Presa Tablachaca de la Central Hidroelectrica Mantaro, Peru, in Proceedings: 2nd Pan-American Symposium on Landslides, Rio de Janeiro, November, v. 2, p. 747-753.

de Luccia, E.R., 1958, Lewis River development, in Souvenir-U.S. dam study tours: Omaha District, Corps of Engineers, 6th International Congress on Large Dams, New York, September 15-20, p. 156-160.
Demirev, A., 1979, Engineering geological conditions of high dams in the folded regions of Bulgaria: International Association of Engineering Geology Bulletin, no. 20, p. $80-83$.

Desio, A., 1973, Geologia applicata alla ingegneria: Hoepli, Milan, 1,194 p.

Dibblee, T.W., 1988, Geologic map of the Ventura and Pitas Point quadrangles: Santa Barbara, Calif., Dibblee Geological Foundation, scale 1:24,000.

Dibblee, T.W., 1980, Preliminary geologic map of the Las Trampas Ridge quadrangle, Alameda and Contra Costa Counties, California: U.S. Geological Survey Open-File Report 80-545, scale 1:24,000.

Dluzewski, J., Hrabowski, W., Opyrchal, L, and Tomaszewicz, A., 2000, Interactive control system of the abutment stability-Wisla-Czarne Dam site, in Transactions: 20th International Congress on Large Dams, International Commission on Large Dams, Beijing, September 19-22, v. 3, p. 51-58.

DNOCS, 1982, Dams in the northeast of Brazil—DNOCS experience in dams in semi-arid region: Fortaleza, Brazil, Ministry of Interior, National Department of Works Against Droughts, $158 \mathrm{p}$.

Dounias, G.T., Pantelidis, P.I., Marinos, P.G., and Vaughan, P.R., 1996, Landslide reactivation in flysch colluvia at the Evinos Dam site, in Senneset, K., ed., Landslides: Proceedings, 7th International Symposium on Landslides, Trondheim, June 17-21, v. 2, p. 1,201-1,206.

Dow, G., 1995, Engineering geology of Jordanelle Dam and Reservoir, Bonneville unit, central Utah project, Utah, in Lund, W.R., ed., Environmental \& engineering geology of the Wasatch Front region: Proceedings, 1995 Utah Geological Association Symposium and Field Conference, Salt Lake City, September 22-23, Utah Geological Association Publication 24, p. 319-344.

Dunn, A.B., 1999, Geologic setting and preliminary hydrologic analysis of the Costilla Dam, New Mexico, landslide [abs.]: Geological Society of America Abstracts with Programs, v. 31, no. 7, p. A-286.

Dunn, A.B., 2000, Geology and hydrology of the Costilla Dam landslide, Taos County, New Mexico: Socorro, New Mexico Institute of Mining and Technology, M.S. thesis, number of pages not available. 
Dunn, A.B., and Haneberg, W.C., 1998, Geologic setting of the Costilla Dam, New Mexico, landslide [abs.]: Association of Engineering Geologists Program with Abstracts, 41st Annual Meeting, Seattle, September-October, Errata to Technical Sessions, p. 4.

Eckerlin, R.D., 1992, Mud Mountain Dam concrete cutoff wall-a case history: Association of Engineering Geologists Bulletin, v. 29, no. 1, p. 11-32.

Eckerlin, R.D., 1993, Mud Mountain Dam concrete cutoff wall, in Anderson, L.R., ed., Geotechnical practice in dam rehabilitation: Proceedings of a specialty conference, American Society of Civil Engineers, Raleigh, N.C., April 25-28, p. 284-298.

Eisbacher, G.H., 1983, Slope stability, Southern Coast Mountains and Fraser Lowland: Field Trip Notes, Cordilleran Section, Geological Association of Canada, Vancouver, B.C., October 16, 46 p.

Ellis, M.S., and Gabaldo, V., 1989, Geologic map and cross sections of parts of the Grand Junction and Delta $30^{\prime} \times 60^{\prime}$ quadrangles, west-central Colorado: U.S. Geological Survey Coal Investigations Map C-124, scale 1:100,000.

Engineering Division, 1958, Oahe Dam on the Missouri River, in Souvenir-U.S. dam study tours: Omaha District, Corps of Engineers, 6th International Congress on Large Dams, International Commission on Large Dams, New York, September 15-20, p. 65-72.

Engineering News-Record, 1937, Small earthfill dam fails: June 24, p. 932.

Evans, S.G., and Savigny, K.W., 1994, Landslides in the Vancouver-Fraser Valley-Whistler Region, in Monger, J.W.H., ed., Geology and geological hazards of the Vancouver Region, southwestern British Columbia: Geological Survey of Canada Bulletin 481, p. 251-286.

Everitt, B., 1993, Memorandum on phase II geologic review of Recapture Dam: Utah Division of Water Resources Memorandum, Salt Lake City, February 18, 9 p.

Everitt, B., and Schuster, R.L., 1999, Dams on landslides in Utah [abs.]: Association of Engineering Geologists Program with Abstracts, 42nd Annual Meeting, Salt Lake City, September 26-29, p. 64.

Federal Emergency Management Agency (U.S.), 1996, Water control infrastructure-National inventory of dams: Washington, D.C. (CD-ROM).
Fell, R., Hungr, O., Leroueil, S., and Riemer, W., 2000, Keynote lecture-geotechnical engineering of the stability of natural slopes, and cuts and fills, in GeoEng2000: Lancaster, U.K., Technomic Publishing Co., Inc., Proceedings, International Conference on Geotechnical \& Geological Engineering, Melbourne, November 19-24, p. 21-120.

Fell, R., MacGregor, P., and Stapledon, D., 1992, Geotechnical engineering of embankment dams: Rotterdam, Balkema, $675 \mathrm{p}$.

Fernández, T., Irigaray, C., and Chacon, J., 1996, Inventario de movimientos de ladera en el borde noreste de la Sierra de Los Guájares (Granada) mediante un S.I.G., in Proceedings: 6th Spanish Congress and International Conference on Environmental Geology and Land-Use Planning, Granada, April 22-25, v. 1, p. 419-441.

Fernandez del Castillo, T., Brabb, E., Delgado Salazar, F., Martin-Algarra, A., Irigaray Fernandez, C., Estevez Rubio, A., and Chacon Montero, J., 1997, Rasgos geologicos y movimientos de ladera en el sector Izbor-Velez Benaudalla de la cuenca del Rio Guadalfeo (Granada), in Proceedings: 4th Simp. Nacional sobre Taludes y Laderas Inestables, Granada, November 11-14, p. 795-808.

Figueroa, M.C., Lhez, M.H., and Pronsato, M.A.D., 1976, Stability and drainage revision of dam and right bank "Quebrada de Ullum Project," in Transactions: 12th International Congress on Large Dams, International Commission on Large Dams, Mexico City, March-April, v. 2, p. 17-26.

Fookes, P.G., Baynes, F.J., and Hutchinson, J.N., 2000, Total geological history - a model approach to the anticipation, observation and understanding of site conditions, in GeoEng2000: Proceedings, International Conference on Geotechnical \& Geological Engineering, Melbourne, 19-24 November, v. 1, p. 370-460.

Fookes, P.G., and Dale, S.G., 1992, Comparison of interpretations of a major landslide at an earthfill dam site in Papua New Guinea: Quarterly Journal of Engineering Geology, v. 25 , p. 313-330.

Fookes, P.G., Dale, S.G., and Land, J.M., 1991, Some observations on a comparative aerial photograph interpretation of a landslipped area: Quarterly Journal of Engineering Geology, v. 24, p. 249-265.

Forrest, M., Roadifer, J., and Leeflang, W., 2001, Long Park Dam rehabilitation-design and construction of seepage control system, in The future of dams and their reservoirs: 21st Annual USSD Lecture Series, United States Society on Dams, Denver, July 30-August 3, p. 59-73. 
Foster, P.F., Amos, P.D., and Silvester, P.K., 2000, Monitoring of Clyde and Roxburgh gravity dams and their schist foundations, in Transactions: 20th International Congress on Large Dams, International Commission on Large Dams, Beijing, September 19-22, v. 3, p. 79-92.

Foster, P.F., Riddolls, B.W., and Macfarlane, D.F., 1996, Response of Clyde slide, New Zealand, to toe inundation, in Senneset, K., ed., Landslides: Proceedings, 7th International Symposium on Landslides, Trondheim, June 17-21, v. 2, p. 727-731.

Fukuoka, M., and Taniguchi, T., 1961, Research on landslides-Un exemple de grand glissement dans une masse de roche et de sol, in Proceedings: 5th International Conference on Soil Mechanics and Foundation Engineering, Paris, July 17-22, v. 2, p. 603-605.

Gagliardi, J., and Routh, R., 1993, Geotechnical modifications at Meeks Cabin Dam, in Anderson, L.R., ed., Geotechnical practice in dam rehabilitation: Proceedings of a specialty conference, American Society of Civil Engineers, Raleigh, N.C., April, p. 755-769.

Galster, R.W., 1989a, Howard A. Hanson Dam, in Galster, R.W., ed., Engineering geology in Washington: Washington Division of Geology and Earth Resources Bulletin 78, v. 1, p. 233-240.

Galster, R.W., 1989b, Mud Mountain Dam, in Galster, R.W., ed., Engineering geology in Washington: Washington Division of Geology and Earth Resources Bulletin 78, v. 1, p. 241-248.

García Yagüe, A., and Fernández Montero, A., 1986, Slope instabilities and site selections for the 'Pas' reservoir, Santander, Spain, in Proceedings: 5th International Congress, International Association of Engineering Geology, Buenos Aires, October 20-25, v. 2, p. 1,259-1,265.

Garga, V.K., and de la Torre, M., 2004, The Tablachaca slide no. 5, Peru-a 20-year post-remediation assessment, in Lacerda, W.A., Ehrlich, M., Fontoura, S.A.B., and Sayão, A.S.F., eds., Landslides-evaluation and stabilization: Leiden, the Netherlands, A.A. Balkema Publishers, Proceedings, 9th International Symposium on Landslides, Rio de Janeiro, June 28-July 2, v. 2, p. 1,691-1,696.

Gignoux, M., and Barbier, R., 1955, Geologie des barrages et des amenagements hydrauliques: Paris, Masson and Co., $343 \mathrm{p}$.

Gillon, M.D., and Hancox, G.T., 1991, Cromwell Gorge landslides - a general overview, in Bell, D.H., ed., Landslides: Proceedings, 6th International Symposium on Landslides, Christchurch, February 10-14, 1992, v. 1, p. 83-102.
Glover, T., Craddock, T., and Harder, L.F., Jr., 1997, Castaic Dam left abutment stability evaluation, in Proceedings: ASDSO Western Regional Conference, Association of State Dam Safety Officials, Oklahoma City, Okla., May 5-7, p. 105-126.

Goodman, R.E., 1993, Engineering geology_rock in engineering construction: New York, Wiley, 413 p.

Gordon, G., 1937, Arch dam of ice stops slide: Engineering News-Record, February 11, p. 211-215.

Graybeal, K.D., 1991, Seepage cutoff wall design and construction in Mud Mountain Dam, in Proceedings: 1991 Annual Conference, Association of State Dam Safety Officials, San Diego, September 29-October 2, v. 1, p. 91-107.

Grosman, M., and Lejsek, J., 1965, The Nechranice Dam under construction: Prague, Documentation Centre of the Management of Water Development, $40 \mathrm{p}$.

Gulick, C.W., and Korosec, M.A., 1990, Geologic map of the Banks Lake 1:100,000 quadrangle, Washington: Washington Division of Geology and Earth Resources Open-File Report 90-6, scale 1:100,000.

Haddaoui, M., and Benabbou, L., 1991, Travaux de confortement du barrage Nakhla, in Transactions: 17th International Congress on Large Dams, International Commission on Large Dams, Vienna, June 17-21, v. 1, p. 1,259-1,279.

Haffen, M., 1955, Barrage de la Chaudanne travaux de consolidation et d'étanchement, in Transactions: 5th International Congress on Large Dams, International Commission on Large Dams, Paris, May-June, v. 4, p. 1,105-1,119.

Hail, W.B., Jr., 1968, Geology of southwestern North Park and vicinity, Colorado: U.S. Geological Survey Bulletin 1257, 119 p., 3 pls.

Hall, C.A., Jr., 1978, Geologic map of Twitchell Dam and parts of Santa Maria and Tepusquet Canyon quadrangles, Santa Barbara County, California: U.S. Geological Survey Miscellaneous Field Studies Map MF-933, scale 1:24,000.

Hamilton, P., 1992, Hydroelectric dams in the Sierras of the Southern California Edison Company, in Pipkin, B.W., and Proctor, R.J., eds., Engineering geology practice in Southern California: Belmont, Calif., Star Publishing Company, Association of Engineering Geologists, Southern California Section, Special Publication 4, p. 667-678.

Hammer, G., 2002, If it ain't broke....or is it?, in Dam safety: Proceedings, 2002 Annual Conference, Association of State Dam Safety Officials, Tampa, Florida, September 8-11, p. $43-49$. 
Hammond, C.M., 1999, Frog Lake landslide and dam reconstruction, northern Oregon Cascades [abs.]: Association of Engineering Geologists Program with Abstracts, 42nd Annual Meeting, Salt Lake City, Utah, September 26-29, p. 67.

Hammond, C.M, and Griffiths, J.B., 1998, An overview of engineering geology applied to facilities in Oregon, in Burns, S., ed., Environmental, groundwater and engineering geology - applications from Oregon: Belmont, Calif., Star Publishing Company, p. 27-33.

Haneberg, W.C., 1999, Reactivation of the Costilla Dam, New Mexico, landslide during dam reconstruction [abs.]: Geological Society of America Abstracts with Programs, 1999 Annual Meeting, Denver, October 25-28, v. 31, no 7, p. A-286.

Hanegan, G.L., 1973, Castaic Dam-a case history of geologic engineering problems and their solutions, in Moran, D.E., Slosson, J.E., Stone, R.O., and Yelverton, C.A., eds., Geology, seismicity, and environmental impact: Association of Engineering Geologists Special Publication, p. 201-211.

Harty, K, 1991, Landslide map of Utah: Utah Geological and Mineral Survey, 28 p. plus map (scale 1:500,000).

Haws, E.T., Martin, P.L., and Yu, T.H., 1985, Devil's Dingle ash disposal works dam, in Proceedings: 11th International Conference on Soil Mechanics and Foundation Engineering, San Francisco, August 12-16, v. 3, p. 1,253-1,256.

Hayes, G.S., 1981, Geologic stability of Mystic Lake Dam, Gallatin County, Montana, and computer simulation of potential flood hazards from failure of the dam: Bozeman, Montana State University, M.S. thesis, 120 p.

Heidstra, N.N., Murray, L.M., Morrison, M.A., and Archibald, P.R., 1995, Seismic upgrading of Seymour Falls Dam, in Waterpower '95: American Society of Civil Engineers, an International Conference \& Exposition on Hydropower, San Francisco, July, not paginated.

High Country Independent Press, 1985, Mystic Dam breached: Bozeman, Mont., March 27, p. 5.

Hobst, L., and Zajíc, J., 1983, Anchoring in rock and soil: Amsterdam, Elsevier, 570 p.

Holdredge, C.P., 1957, Geologic reports on damsites in the John Day Basin, Oregon, in Trask, P.D., ed., Engineering geology case histories: Geological Society of America, no. 1, p. 25-32.
Holton, D., 1983, Flood-highway reopened after dam collapse: Daily Argus Observer, Ontario, Oreg., April 1, p. 1.

Horský, O., and Spanilá, T., 1997, Remodeling of water reservoir banks by exogenous processes, in Marinos, P.G., Koukis, G.C., Tsiambaos, G.C., and Stournaras, G.C., eds., Engineering geology and the environment: Proceedings, International Symposium on Engineering Geology and the Environment, International Association of Engineering Geology, Athens, June 23-27, v. 3, p. 2,711-2,716.

Horswill, P., and Horton, A., 1976, Cambering and valley bulging in the Gwash valley at Empingham, Rutland: Royal Society of London Philosophical Transactions, A, v. 283, p. 427-462.

Howell, P.W., 1952, Geologic background of slides at Lookout Point Reservoir, Oregon: Proceedings of the Oregon Academy of Science, v. 3, p. 32.

Hrdy, J., and Mares, I., 1978, Rock slide in the right bank of the Dalešice Dam, in Proceedings: 3rd International Congress, International Association of Engineering Geology, Madrid, September, Section 3, v. 1, p. 152-155.

Hunter, J.B., 1982, Some examples of design changes required during construction, in Balasubramaniam, A.S., Yudhbir, and Tomiolo, A., eds., Proceedings: International Symposium on Geotechnical Problems and Practice of Engineering, Bangkok, December, p. 99-108.

Hunter, J.F., 1918, Mosca Reservoir, in Atwood, W.W., Relation of landslide and glacial deposits to reservoir sites in the San Juan Mountains, Colorado: U.S. Geological Survey Bulletin 685, p. 26-29.

Hutchinson, J.N., 1988, General report-Morphological and geotechnical parameters of landslides in relation to geology and hydrology, in Bonnard, C., ed., Landslides: Rotterdam, A.A. Balkema, Proceedings, 5th International Symposium on Landslides, v. 1, p. 3-35.

International Commission on Large Dams, 1974, Lessons from dam incidents: Paris, 1,069 $\mathrm{p}$.

International Commission on Large Dams, 1983, Deterioration of dams and reservoirs: Paris, December, 367 p.

Irwin, W.H., 1938, Geology of the rock foundation of Grand Coulee Dam, Washington: Geological Society of America Bulletin, v. 49, p. 1,627-1,650. 
Ischy, E., and Haffen, M., 1955, Barrage de Serre-Ponçon, campagnes de reconnaissances, in Transactions: 5th International Congress on Large Dams, International Commission on Large Dams, Paris, May-June, v. 1, p. 803-831.

Izett, G.A., and Barclay, C.S.V., 1973, Geologic map of the Kremmling quadrangle, Grand County, Colorado: U.S. Geological Survey Geologic Quadrangle Map GQ-1115, scale 1:62,500.

Jalote, S.P., Shome, S.K., and Mehta, P.N., 1975, Yamuna Hydel Scheme, Uttar Pradesh, in Engineering geology case histories: Geological Survey of India Miscellaneous Publication 29, part 1, p. 118-130, part 2, pl. 37.

Jalote, S.P., and Tikku, A.K., 1975, Beas Dam project, in Engineering geology case histories: Geological Survey of India Miscellaneous Publication 29, part 1, p. 107-117, part 2, pl. 34.

Japanese National Committee on Large Dams, 1979, Dams in Japan: no. 8, 63 p.

Jaspar, J.L., and Peters, N., 1979, Foundation performance of Gardiner Dam: Canadian Geotechnical Journal, v. 16, p. $758-788$.

Jensen, J.R., 1981, Swift hydro-electric project, in Engineering geology in the Pacific Northwest: Association of Engineering Geologists Field Trip Guidebook, 24th Annual Meeting, Portland, Oreg., September-October, p. 186-193.

Kawashima, T., and Kanazawa, K., 1982, Design of rockfill dams on weathered foundation with large scale faults, in Transactions: 14th International Congress on Large Dams, International Commission on Large Dams, Rio de Janeiro, May 3-7, v. 2, p. 75-99.

Keech, C.E., and Sanford, B.A., 1998, Tooth Rock landslide, Columbia Gorge, Oregon, in Burns, S., ed., Environmental, groundwater and engineering geology-applications from Oregon: Belmont, Calif., Star Publishing Company, p. 367-372.

Kehew, A.E., 1983, Geology and geotechnical conditions of the Minot area, North Dakota: North Dakota Geological Survey Report of Investigations 73, 35 p.

Kent, M.D., 1981, Geology of the Warm Springs-Pelton area, in Field trip guidebook: Association of Engineering Geologists, 24th Annual Meeting, Portland, Oreg., September 27-October 2, p. 57-69.
Kiersch, G.A., and James, L.B., 1991, Errors of geologic judgment and the impact on engineering works, in Kiersch, G.A., ed., The heritage of engineering geology; the first hundred years: Geological Society of America, Centennial Special Vol. 3, p. 517-558.

Kintzer, F.C., 1980, Geology and landslides at Calaveras Reservoir, Alameda and Santa Clara Counties, California: Hayward, California State University, M.S. thesis, 138 p.

Kirkaldie, L., and Thomas, L.E., 1984, Dissecting a dam: Association of Engineering Geologists Bulletin, v. 21, no. 4, p. 509-514.

Knight, D.K., 1963, Oahe Dam—geology, embankment, and cut slopes: Journal of the Soil Mechanics and Foundations Division, American Society of Civil Engineers, v. 89, no. SM2, p. 99-125.

Kocahan, H.T., and Taylor, G.M., 2002, Rehabilitation of Black Rock Dam-“"seepage and inadequate spillway," in Dam safety: Proceedings, 2002 Annual Conference, Association of State Dam Safety Officials, Tampa, Fla., September 8-11, p. 223-240.

Konteatis, C.A.C., 1974, Dams of Cyprus: Nicosia, Republic of Cyprus, Ministry of Agriculture and Natural Resources, $264 \mathrm{p}$.

Krapp, L., and Pantzartzís, P., 1989, Besondere ingenieurgeologische und hydrogeologische Aufgaben beim Talsperrenbau in N. Griechenland: Mitt. Ing.-u. Hydrogeologie, RWTH Aachen, v. 32, p. 77-107.

Kropatschek, H., and Rienössl, K., 1967, Travaux d'étanchement du sous-sol du barrage de Durlassboden, in Transactions: 9th International Congress on Large Dams, International Commission on Large Dams, Istanbul, September 4-8, v. 1, p. 695-713.

Kumara, H.M.A., and Kulasinghe, A.N.S., 1986, Studies of slope stability problems in the Kotmale Hydropower Project area-Sri Lanka, in Gardiner, V., ed., International geomorphology 1986: Chichester, U.K., Wiley, Proceedings, 1st International Conference on Geomorphology, Part I, p. 111-119.

Kunzer, A., 1998, Spillway modifications-Ochoco Dam, Crooked River project, Oregon, in Proceedings: 33rd Symposium on Engineering Geology and Soils Engineering, Reno, Nev., March 25-27, p. 37-47. 
Lapworth, H., 1911, The geology of dam trenches: Institution of Water Engineers Transactions, London, v. 16, p. 25-66.

Lauffer, H., and Schober, W., 1964, The Gepatsch rockfill dam in the Kauner, in Transactions: 8th International Congress on Large Dams, International Commission on Large Dams, Edinburgh, May 4-8, v. 3, p. 635-660.

Lavania, B.V.K., 1988, Treatment of left bank slopes of Ichari Dam, in Proceedings: 2nd International Conference on Case Histories in Geotechnical Engineering, St. Louis, p. $621-625$.

Legget, R.F., 1939, Geology and engineering: New York, McGraw-Hill, 650 p.

Legget, R.F., and Hatheway, A.W., 1988, Geology and engineering: New York, McGraw-Hill, 613 p.

Legget, R.F., and Karrow, P.F., 1983, Handbook of geology in civil engineering: New York, McGraw-Hill, 50 chap [variously paged].

Lemke, R.W., 1960, Geology of the Souris River Area, North Dakota: U.S. Geological Survey Professional Paper 325, $138 \mathrm{p}$.

Leobacher, A., 2000, Detection of abnormal leakage at Eberlaste earthfill dam, in Transactions: 20th International Congress on Large Dams, International Commission on Large Dams, Beijing, September 19-22, v. 3, p. 1,221-1,233.

Li, J., and Luo, D., 1981, The formation and characteristics of mudflow and flood in the mountain area of the Dachao River and its prevention: Zeitung Geomorphologie N.F., v. 25 , no. 4 , p. $470-484$.

Lilly, R.N., 1986, Wungong Dam landslide: Australian National Committee on Large Dams Bulletin 74, p. 38-49.

Lipman, P.W., 1975, Geologic map of the Lower Conejos River Canyon, southeastern San Juan Mountains, Colorado: U.S. Geological Survey Miscellaneous Investigations Series Map I-901, scale 1:48,000.

Lockhart, A.C., 1998, Agate Dam, Jackson County, southern Oregon, in Burns, S., ed., Environmental, groundwater and engineering geology_applications from Oregon: Belmont, Calif., Star Publishing Company, p. 127-131.

Logan, M.H., and Davis, F.J., 1972, Landslide at Silver Jack Dam, in Proceedings: Specialty Conference on Performance of Earth and Earth-supported Structures, American Society of Civil Engineers, Purdue University, West Lafayette, Ind., June, v. 3, p. 315-325.
Lopez Marinas, J.M., Gaztañaga, J.M., and Cajete, J., 1997, Landslides in the Cortes Reservoir (River Júcar, Valencia, Spain) during initial filling, in Transactions: 19th International Congress on Large Dams, International Commission on Large Dams, Florence, May 26-30, v. 3, p. 537-550.

Lordet, J., Duquennois, H., and Guilhamon, J., 1955, Hydroelectric development of the Oued Agrioun, in Review travaux: 5th International Congress on Large Dams, International Commission on Large Dams, Paris, May-June, Supplement no. 247, p. 190-206.

Lowe, J., III, 1988, Earthfill dams, in Kollgard, E.B., and Chadwick, W.L., eds., Development of dam engineering in the United States: New York, Pergamon Press, Prepared in commemoration of the 16th International Congress on Large Dams, United States Committee on Large Dams, p. 671-884.

Lukáč, M., 1985, Measures for limiting seepages in the foundation of two earth dams in operation, in Transactions: 15th International Congress on Large Dams, International Commission on Large Dams, Lausanne, June 24-28, v. 3, p. 643-651.

Macfarlane, D.F., and Gillon, M.D., 1995, The performance of landslide stabilization measures, Clyde power project, New Zealand, in Bell, D.H., ed., Landslides: Proceedings, 6th International Symposium on Landslides, Christchurch, February 10-14, 1992, v. 3, p. 1,747-1,757.

Machette, M.N, Anderson, R.E., Joyner, W.R., Schuster, R.L., and Swolfs, H.S., 1991, Review of geotechnical aspects of the Jordanelle damsite, Heber, Utah: U.S. Geological Survey Open-File Report 91-398, 43 p.

Madole, R.F., 1982, Surficial geologic map of the Craig $12^{\circ} \times 1^{\circ}$ quadrangle, Moffat and Routt Counties, Colorado: U.S. Geological Survey Miscellaneous Investigations Series Map I-1346, scale 1:100,000.

Madole, R.F., 1989, Surficial geologic map of the Meeker $30^{\prime} \times 60^{\prime}$ quadrangle, Garfield, Moffat, Rio Blanco, and Routt Counties, Colorado: U.S. Geological Survey Miscellaneous Investigations Series Map I-1823, scale $1: 100,000$.

Madole, R.F., 1991a, Surficial geologic map of the Steamboat Springs $30^{\prime} \times 60^{\prime}$ quadrangle, Grand, Jackson, and Routt Counties, Colorado: U.S. Geological Survey Miscellaneous Investigations Series Map I-1825, scale 1:100,000.

Madole, R.F., 1991b, Surficial geologic map of the Walden $30^{\prime} \times 60^{\prime}$ quadrangle, Jackson, Larimer, and Routt Counties, Colorado: U.S. Geological Survey Miscellaneous Investigations Series Map I-1824, scale 1:100,000. 
Major, J.J., and Scott, K.M., 1988, Volcaniclastic sedimentation in the Lewis River valley, Mount St. Helens, Washington-processes, extent, and hazards: U.S. Geological Survey Bulletin 1383-D, 38 p.

Malgot, J., Baliak, F., and Kopecký, M., 2002, Assessment of the Liptovská Mara landslide, in Rybáŕ, J., Holzer, R., and Kopecký, M., eds., Post-conference field trip guide, east of the Czech Republic and Slovakia: 1st European Conference on Landslides, Prague, June, p. 48-51.

Marsal, R.J., and Reséndiz, D., 1971, Effectiveness of cutoffs in earth foundations and abutments of dams, in Proceedings: 4th Panamerican Conference on Soil Mechanics and Foundation Engineering, San Juan, Puerto Rico, June, v. 1, p. 237-312.

Martin, D.O., 1974, Understanding and treatment of dam foundations, in Lessons from dam incidents: International Commission on Large Dams, Paris, p. 245-263.

McLaughlin, R.J., Clark, J.C., Brabb, E.E., and Helley, E.J., 1991, Geologic map and structure sections of the Los Gatos 7.5' quadrangle, Santa Clara and Santa Cruz Counties, California: U.S. Geological Survey Open-File Report 91-593, 50 p. plus 3 maps, scale 1:24,000.

Mencl, V., 1977, Modern methods used in the study of mass movements: International Association of Engineering Geology Bulletin, no. 16, p. 185-197.

Mignon, K., 1968, Zur Geologie im Raume der Oberstufe des Gerloskraftwerkes: Österreichische Zeitschrift für Elektrizitätwirtschaft, v. 21, no. 8, p. 391-397.

Mikuni, E., 1980, Dam engineering activities in Japan, in Balasubramaniam, A.S., Yudhbir, and Tomiolo, A., eds., Proceedings: Symposium on Geotechnical Problems and Practice of Dam Engineering, Bangkok, December 1-15, p. 109-130.

Millet, R.A., Lawton, G.M., Repetto, P.C., and Garga, V.K., 1992, Stabilization of Tablachaca Dam landslide, in Proceedings: Specialty Conference on Stability and Performance of Slopes and Embankments, Berkeley, Calif., June 29-July 1, v. 2, p. 1,365-1,381.

Mohammadi, A., Kessler, D., Doane, J., and Vessely, A., 2000, An integrated strategy for seepage control from Bull Run \#2 spillway approach canal, in Proceedings: 20th International Congress on Large Dams, International Commission on Large Dams, Beijing, September 19-22, v. 3, p. 687-702.

Montgomery S.B., 1980, Geologic map of Recapture Creek Dam \& Reservoir Site: Utah Division of Water Resources, Salt Lake City, scale 1:1200.
Moore, D.P., and Mathews, W.H., 1978, The Rubble Creek landslide, southwestern British Columbia: Canadian Journal of Earth Sciences, v. 15, no. 7, p. 1,039-1,052.

Morales Arnao, B., Garga, V.K., Wright, R.S., and Perez, J-Y., 1984, The Tablachaca slide no. 5, Peru, and its stabilization, in Proceedings, 4th International Symposium on Landslides, Toronto, September 16-21, v. 1, p. 597-604.

Moreno, H., Thiele, R., and Varela, J., 1991, Estudio Geologico y de Riesgo Volcanico y de Remocion en Masa del Proyecto Hidroelectrico Alfalfal II-Las Laja: Report for CHILGENER, Santiago, Chile, number of pages not available.

Morton, D.M., and Streitz, R., 1969, Preliminary reconnaissance map of major landslides, San Gabriel Mountains, California: California Division of Mines and Geology Map Sheet 15, scale 1:63,360.

Mumford, J.A., 1994, Public response to emergency evacuation of Ochoco Reservoir, in Proceedings: 1994 Annual Conference, Association of State Dam Safety Officials, Boston, September 11-14, p. 513-517.

Neff, G.E., 1989, Columbia Basin Project, in Galster, R.W., ed., Engineering geology in Washington: Washington Division of Geology and Earth Resources Bulletin 78, v. 1, p. 539-563.

Nemcok, A., 1982, Zosuvy v Slovenských Karpatoch: VEDA, vydavaatel'stvo Slovenskej akadémie vied, Bratislava, 319 p.

Newman, F.B., Curtiss, R.E., Jr., Gower, T.R., and Roth, B.L., 2000, Stabilization of landslide at McElroy's Run impoundment using auger cast grout columns, in Tailings dams 2000: Proceedings, Tailings Dam 2000 Conference, Association of State Dam Safety Officials, Las Vegas, Nev., March 28-30, p. 187-196.

New Zealand Geomechanics Society, 1992, Guide to landslides technical tour: Sixth ISL Pre-Symposium Field Seminar, 6th International Symposium on Landslides, Queenstown, New Zealand, February 8, 15 p., plus attachments.

Nilsen, T.H., 1972a, Preliminary photointerpretation map of landslide and other surficial deposits of parts of the Los Gatos, Morgan Hill, Gilroy Hot Springs, Pacheco Pass, Quien Sabe, and Hollister 15-minute quadrangles, Santa Clara County, California: U.S. Geological Survey Miscellaneous Field Studies Map MF-416, scale 1:62,500. 
Nilsen, T.H., 1972b, Preliminary photointerpretation map of landslide and other surficial deposits of the Mount Hamilton quadrangle and parts of the Mount Boardman and San Jose quadrangles, Alameda and Santa Clara Counties, California: U.S. Geological Survey Miscellaneous Field Studies Map MF-339, scale 1:62,500.

Nilsen, T.H., 1973, Preliminary photointerpretation map of landslide and other surficial deposits of the Concord 15minute quadrangle and the Oakland West, Richmond, and part of the San Quentin 7 1/2-minute quadrangles, Contra Costa and Alameda Counties, California: U.S. Geological Survey Miscellaneous Field Studies Map MF-493, scale 1:62,500.

Norfleet, J., and Marvin, B., 1995, Monument Dam—a case study - instrumentation of landslide enables continued operation of reservoir without compromising safety, in Proceedings: 1995 Annual Conference, Association of State Dam Safety Officials, Atlanta, September 17-20, p. 705-714.

Novosad, S., 1979, Establishing conditions of equilibrium of landslides in dam reservoirs by means of geoacoustic (rock noise) method: International Association of Engineering Geology Bulletin 20, p. 138-144.

Novosad, S., 1990, Evaluation and mitigation of geologic hazard related to the construction of Slezska Harta Dam on the Moravice River in Czechoslovakia, in Proceedings: 6th International Congress, International Association of Engineering Geology, Amsterdam, August 6-10, v. 2, p. $1,941-1,948$.

Novosad, S., Barvinek, R., and de la Torre Sabrevilla, M., 1979, Estudio de estabilidad del Derrumbe No. 5 en el Reservorio de Tablachaca de la Central Hidroelectrica del Mantaro, in Proceedings: 6th Panamerican Conference on Soil Mechanics and Foundation Engineering, Lima, December, v. 1, p. 331-344.

Novosad, S., and Novosad, L., eds., 1993, Field work shop guide-CS (Czechoslovak) landslide field trip: 7th ICFL (International Conference and Field Workshop on Landslides), Prague, August 28-September 15, number of pages not available.

Ohta, H., Tokida, K., Tsunaki, R., Ohmori, K., and Ozou, H., 1996, Case study of a colossal rock mass slide along discontinuity surface, in Senneset, K., ed., Landslides: Proceedings, 7th International Symposium on Landslides, Trondheim, June 17-21, v. 2, p. 841-846.
Okuno, T., Wang, F.W., and Matsumoto, T., 2004, The deforming characters of the giant Jinnosuke-dani landslide in Haku-san mountainous area, Japan, in Lacerda, W.A., Ehrlich, M., Fontoura, S.A.B., and Sayão, A.S.F., eds., Landslides - evaluation and stabilization: Leiden, the Netherlands, A.A. Balkema Publishers, Proceedings, 9th International Symposium on Landslides, Rio de Janeiro, June 28-July 2, v. 2, p. 1,279-1,285.

O'Reilly, R.P., 1958, Hydroelectric development on the Clackamas River, Oregon, in Souvenir-U.S. dam study tours: 6th International Congress on Large Dams, Omaha District, Corps of Engineers, New York, September 15-20, p. 150-155.

Oriel, S.S., and Moore, D.W., 1985, Geologic map of the West and East Palisades Roadless Areas, Idaho and Wyoming: U.S. Geological Survey Miscellaneous Field Studies Map MF-1619-B, scale 1:50,000.

Outland, C.F., 1977, Man-made disaster; the story of the St. Francis Dam: Glendale, Calif., Arthur H. Clark Company, $275 \mathrm{p}$.

Palmer, L., 1977, Large landslides of the Columbia River Gorge, Oregon and Washington, in Coates, D.R., ed., Reviews in engineering geology: Geological Society of America, v. 3, p. 69-83.

Pardini, R.J., and Reichert, G.A., 1993, Austrian Dam spillway replacement, in Proceedings: 1993 Annual Conference, Association of State Dam Safety Officials, Kansas City, Mo., September 26-29, p. 473-478.

Paterson, S.J., 1971, Engineering geology of the Lemonthyme hydro-electric scheme, Tasmania: Civil Engineering Transactions, Australian Institution of Engineers, April, p. 17-24.

Peters, N., and Long, W.C., 1981, Performance monitoring of dams in western Canada, in Kulhawy, F.H., ed., Proceedings: Geotechnical Engineering for Hydro Projects-Embankment Dam Instrumentation Performance, Engineering Geology Aspects, Rock Mechanics Studies, American Society of Civil Engineers, New York, May $11-12$, p. 23-45.

Philbrick, S.S., 1976, Kinzua Dam and the glacial foreland, in Coates, D.R., ed., Geomorphology and engineering: Stroudsburg, Pa., Dowden, Hutchinson \& Ross, Inc., p. 175-197. 
Picarelli, L, and Russo, C., 2004, Remarks on the mechanics of slow active landslides and the interaction with man-made works, in Lacerda, W.A., Ehrlich, M., Fontoura, S.A.B., and Sayão, A.S.F., eds., Landslides-evaluation and stabilization: Leiden, the Netherlands, A.A. Balkema Publishers, Proceedings, 9th International Symposium on Landslides, Rio de Janeiro, June 28-July 2, v. 2, p. 1,141-1,176.

Popov, N., 1999, Debris flows and their control in Alma-Ata, Kazakhstan, in Sassa, K., ed., Landslides of the world: Kyoto, Kyoto University Press, p. 279-284.

Pronsato, M.A.D, Figueroa Castellanos, M.C., and Lhez, M.H.H., 1973, Spillway design criteria of the "Quebrada de Ullum" Reservoir-San Juan River, in Transactions: 11th International Congress on Large Dams, International Commission on Large Dams, Madrid, June 11-15, v. 2, p. 871-886.

Qi, X., 1986, Evolution of geological environment with water resources and hydropower constructions, in Proceedings: 5th International Congress, International Association of Engineering Geology, Buenos Aires, October 20-25, v. 4, p. 1,161-1,172.

Radbruch-Hall, D.H., and Varnes, D.J., 1976, Landslidescause and effect: International Association of Engineering Geology Bulletin 14, p. 205-216.

Rambert, O., and Gavard, M., 1961, Foundation investigation and treatment, in Barrages en Suisse, course on water and energy: 7th International Congress on Large Dams, International Commission on Large Dams, Rome, June 26-July 1, p. 3-5.

Ramirez Reynaga, M., 1998, Landslide at right abutment of Los Naranjos Dam, Mexico, in Proceedings: 8th International Congress, International Association of Engineering Geology, Vancouver, September 21-25, v. 5, p. 3,087-3,094.

Rattue, D.A., Hammamji, Y., and Tournier, J-P., 2000, Performance of the Sainte Marguerite-3 Dam, during construction and reservoir filling, in Transactions: 20th International Congress on Large Dams, International Commission on Large Dams, Beijing, September 19-22, p. 899-915.

Rattue, D.A., Hammamji, Y., Virolle, F., and Tournier, J.P., 1999, Foundation treatment of the SM-3 dam, in Turfan, M., ed., Proceedings: International Symposium on Dam Foundations and Solutions, Antalya, Turkey, September 23, p. 755-766.
Reheis, M.C., 1984, Geologic map and coal sections of the Thornburgh quadrangle, Moffat and Rio Blanco Counties, Colorado: U.S. Geological Survey Coal Investigations Map C-100, scale 1:24,000.

Repetto, P.C., 1985, The Tablachaca Dam slide no. 5 problem, in Proceedings: 11th International Conference on Soil Mechanics and Foundation Engineering, San Francisco, August 16-21, v. 5, p. 2,599-2,610.

Richey, J.E., 1959, Dam foundations in argillaceous strata: Water Power, February, p. 57-63.

Richey, J.E.,1964, Elements of engineering geology: London, Sir Isaac Pitman \& Sons Ltd., 157 p.

Riemer, W., 1995, Keynote paper-landslides and reservoirs, in Bell, D.H., ed., Landslides: Proceedings, 6th International Symposium on Landslides, Christchurch, February 10-14, 1992, v. 3, p. 1,973-2,004.

Riemer, W., Pantzartzís, P., Krapp, L., and Scourtis, C., 1996, Investigation and monitoring of landslides at the Polyphyton project, in Senneset, K., ed., Landslides: Proceedings, 7th International Symposium on Landslides, Trondheim, June 17-21, v. 1, p. 357-362.

Rienössl, K., and Schnelle, P., 1976, The Durlassboden and Eberlaste embankments large settlements and underseepage in the overburden, in Transactions: 12th International Congress on Large Dams, International Commission on Large Dams, Mexico City, March 29-April 2, v. 2, p. 231-245.

Ringheim, A.S., 1964, Experiences with the Bearpaw Shale at the South Saskatchewan River Dam, in Transactions: 8th International Congress on Large Dams, International Commission on Large Dams, Edinburgh, May 4-8, v. 1, p. 529-550.

Ripley, C.F., and Campbell, D.B., 1963, Earthdam on compressible and pervious foundation: Division Paper of the Engineering Institute of Canada, EIC-63-Geotech 1, v. 1, no. 19,18 p.

Roberts, A.E., 1964, Geologic map of the Mystic Lake quadrangle, Montana: U.S. Geological Survey Miscellaneous Geological Investigations Map I-398, scale 1:24,000.

Rogers, J.D., 1992, Reassessment of the St. Francis Dam failure, in Pipkin, B.W., and Proctor, R.J., eds., Engineering geology practice in Southern California: Belmont, Calif., Star Publishing Company, Association of Engineering Geologists Special Publication 4, p. 639-666. 
Rogers, J.D., 1995, A man, a dam and a disaster-Mulholland and the St. Francis Dam, in Nunis, D.D., Jr., ed., The St. Francis Dam disaster: Los Angeles, Historical Society of Southern California, p. 1-109.

Rogers, J.D., 1997, Man-made disaster at an old landslide dam site, in Ehrenspect, H.E., and Powell, J.R., eds., A day in the field with Thomas Dibblee and J. David Rogers, St. Francis Dam area: Santa Barbara, Calif., Thomas Wilson Dibblee, Jr., Geological Foundation, p. 26-103.

Roy, S., 1975, Jaldhaka hydroelectric project-I stage, West Bengal, in Engineering geology case histories: Geological Survey of India Miscellaneous Publication 29, part 1, p. 199-206.

Saber, R.T., Barranco, A.P., Jr., Wilson, D.B., Finucane, R.B., and Snyder, M.R., 2001, Performance evaluation of Waterbury Dam, in The future of dams and reservoirs: 21st Annual USSD Lecture Series, United States Society on Dams, Denver, July 30-August 3, p. 75-98.

Sager, J.W., 1989, Bonneville Dam, in Galster, R.W., ed., Engineering geology in Washington: Washington Division of Geology and Earth Resources Bulletin 78, v. 1, p. 337-346.

Sager, J.W., and Budai, C.M., 1989, Geology and construction of the Spirit Lake outlet tunnel, Mount St. Helens, Washington, in Galster, R.W., ed., Engineering geology in Washington: Washington Division of Geology and Earth Resources Bulletin 78, v. 2, p. 1,229-1,234.

Sanders, J., Smith, K., and Thom, J.H., 2001, Nevada Creek Dam rehabilitation — save your old spillway for a very rainy day, in The future of dams and their reservoirs: 21st Annual USSD Lecture Series, United States Society on Dams, Denver, July 30-August 3, p. 151-164.

Sanganeria, J.S., 1975, Ranaptrap Sagar project, Chambal Valley development scheme, stage II, in Engineering geology case histories: Geological Survey of India Miscellaneous Publication 29, part 1, p. 41-49, part 2, pl. 15.

Schetelig, K., 1989, Eine ausgedehnte Felssackungszone am Mornos-Damm in Griechenland: Mitt. Ing. u. Hydrogeologie, Aachen, v. 5, no. 3, p. 13-39.

Schnitter, G., 1961, Earth dams, in Barrages en Suisse, Course on water and energy: 7th International Congress on Large Dams, International Commission on Large Dams, Rome, June 26-July 1, p. 31-32.
Schober, W., 1970, The interior stress distribution of the Gepatsch rockfill dam, in Transactions: 10th International Congress on Large Dams, International Commission on Large Dams, Montreal, June 1-5, v. 1, p. 169-187.

Schroeder, W.L., Phelps, R.E., and Tigoulet, A., 1988, Underwater construction of an impervious dam core, in Proceedings: 24th Symposium on Engineering Geology \& Soils Engineering, Coeur d'Alene, Idaho, February 29-March 2, p. 391-407.

Schulz, M.G., 1980, The quantification of soil mass movements and their relationship to bedrock geology in the Bull Run watershed, Multnomah and Clackamas Counties, Oregon: Corvallis, Oregon State University, M.S. thesis, $170 \mathrm{p}$.

Schuster, R.L., 1989, Engineering geologic effects of the 1980 eruptions of Mount St. Helens, in Galster, R.W., ed., Engineering geology in Washington: Washington Division of Geology and Earth Resources Bulletin 78, v. 2, p. 1,203-1,228.

Schuster, R.L., 2003, Dams built on pre-existing landslidesthe Colorado experience, in Boyer, D., Rogers, W.P., and Santi, P.M., eds., Engineering geology of Colorado: Association of Engineering Geologists, Rocky Mountain Section, Denver, 32 p. (CD-ROM).

Schuster, R.L., and Pringle, P.T., 2002, Engineering history and impacts of the Bonneville landslide, Columbia River Gorge, Washington-Oregon, U.S.A., in Rybář, J., Stemberk, J., and Wagner, P., eds., Landslides: Proceedings, 1st European Conference on Landslides, Prague, June 24-26, p. $59-78$.

Secretaría de Recursos Hidráulicos, 1976a, Behavior of dams built in Mexico: Contribution to 12th International Congress on Large Dams, International Commission on Large Dams, Mexico City, March-April, Comisión Federal de Electricidad, 587 p.

Secretaría de Recursos Hidráulicos, 1976b, Grandes presas de Mexico 1976: Mexico City, 244 p.

Sen, P., Subba Rao, C., and Krishnamurthy, G.S., 1987, Case history of foundation remedial measures for a high rockfill dam, in Proceedings: International Symposium on New Materials and Techniques in Dam Construction, Central Board of Irrigation and Power, Madras, India, March 5-7, p. $43-47$.

Sezginer, Y., and Karacaoğlu, B., 1961, Effectiveness of the pile cutoff in Selevir Dam, in Transactions: 9th International Congress on Large Dams, International Commission on Large Dams, Istanbul, September 4-8, v. 1, p. 595-608. 
Shannon, W.D., and Shannon, W.L., 1954, Connell Dam provides water supply for Alaska's first pulp mill: Civil Engineering, American Society of Civil Engineers, v. 24, no. 6, p. 359-363.

Sharma, R.P., Jackson, H.E., and Kumar, S., 1997, Effects of the January 17, 1994, Northridge earthquake on Pacoima arch dam and interim remedial repairs, in Transactions: 19th International Congress on Large Dams, International Commission on Large Dams, Florence, May 26-30, v. 4, p. 127-151.

Sheko, A.I., 1988, Protection and control measures, in Kozlovskii, E.A., ed., Landslides and mudflows: United Nations Educational, Scientific and Cultural Organization/ United Nations Environment Programme, Moscow, v. 1, p. 225-235.

Sherard, J.L., Woodward, R.J., Gizienski, S.F., and Clevenger, W.A., 1963, Earth and earth-rock dams_engineering problems of design and construction: New York, Wiley, 725 p.

Simmler, H., ed., 1977, Large dams in Austria: Österreichische Staubeckencommission, Vienna, 275 p. [translator: R. Partl].

Simpson, D.T., and Schmoll, M., 2001, Exploration, design, and construction of Los Vaqueros Dam, Contra Costa County, California, in Ferriz, H., and Anderson, R., eds., Engineering geology practice in Northern California: California Geological Survey Bulletin 210, Association of Engineering Geologists Special Publication 12, p. 297-310.

Skempas, M., and Chandler, R.J., 1993, Case histories of dams with abutment problems, in Anagnostopoulos, A., Schlosser, F., Kalteziotis, N., and Frank, R., eds., Geotechnical engineering of hard soils-soft rocks: Proceedings of an international symposium, Athens, September 20-23, p. 1,319-1,325.

Snyder, D.T., and Brownell, D.L., 1996, Hydrogeologic setting and preliminary estimates of hydrologic components for Bull Run Lake and the Bull Run Lake drainage basin, Multnomah and Clackamas Counties, Oregon: U.S. Geological Survey Water Resources Investigations Report 96-4064, $47 \mathrm{p}$.

Solomon, B.J., 1999, Surficial geologic map of the West Cache fault zone and nearby faults, Box Elder and Cache Counties, Utah: Utah Geological Survey Map 172, scale $1: 24,000$.

Soule, J.M., 1986, Vega Reservoir access road and vicinity-assessment of landslide hazards and related problems: Colorado Geological Survey Open-File Report 86-6, map scale $1: 4,800$.
Soule, J.M., 1988, Surficial-geologic and landslide map of Vega Reservoir and vicinity, Mesa County, Colorado: Colorado Geological Survey Open-File Report 88-1, 2 pl., scale $1: 24,000$.

Srivastava, K.N., and Agarwal, A.N., 1975, Beas-Sutlej link project, Himachal Pradesh, in Engineering geology case histories: Geological Survey of India Miscellaneous Publication 29, part 1, p. 96-106, part 2, pl. 30.

Stapledon, D.H., 1967, Geological investigations at the site for the Kangaroo Creek Dam, South Australia: Institution of Engineers Civil Engineering Transactions, Australia, v. CE9, p. 31-43.

Staples, L.W., 1964, Landslide at north abutment of Lookout Point Dam, Oregon, in Trask, P.D., ed., Engineering geology case histories: Geological Society of America, no. 1, p. 3-48.

Stoffel, K.L., Joseph, N.L., Waggoner, S.Z., Gulick, C.W., Korosec, M.A., and Bunning, B.B., 1991, Geologic map of Washington-northeast quadrant: Washington Division of Geology and Earth Resources Geologic Map GM-39, scale $1: 625,000$.

Stratton, J.H., 1938, The engineering features of the Conchas Dam project: Boston Society of Civil Engineers Journal, v. 25, p. 497-515.

Stroman, W.R., Beene, R.R.W., and Hull, A.M., 1984, Clay shale foundation slide at Waco Dam, Texas, in Prakash, S., ed., Proceedings: International Conference on Case Histories in Geotechnical Engineering, University of MissouriRolla, May 6-11, p. 579-586.

Subcommittee on Dam Incidents and Accidents, 1988, Lessons from dam incidents, USA-II: American Society of Civil Engineers, Committee on Dam Safety, U.S. Committee on Large Dams, 222 p.

Swanson, D.A., Anderson, J.L., Bentley, R.D., Byerly, G.R., Camp, V.E., Gardner, J.N., and Wright, T.L., 1979, Reconnaissance geologic map of the Columbia River Basalt Group in eastern Washington and northern Idaho: U.S. Geological Survey Open-File Report 79-1363, sheet 6, scale 1:250,000.

Tabor, R.W., Waitt, R.B., Jr., Frizzell, V.A., Jr., Swanson, D.A., Byerly, G.R., and Bentley, R.D., 1982, Geologic map of the Wenatchee 1:100,000 quadrangle, central Washington: U.S. Geological Survey Miscellaneous Investigations Series Map I-1311, scale 1:100,000. 
Tabor, R.W., Frizzell, V.A., Jr., Booth, D.B., and Waitt, R.B., 2000, Geologic map of the Snoqualmie Pass $30^{\prime} \times 60^{\prime}$ quadrangle, Washington: U.S. Geological Survey Geologic Investigations Series I-2538, scale 1:100,000.

Takemura, K., Shimomura, M., Matsumoto, N., and Yamaguchi, Y., 1991, Behaviors of foundations for fill dams during construction and first filling of reservoirs in Japan, in Transactions: 17th International Congress on Large Dams, International Commission on Large Dams, Vienna, June 17-21, v. 3, p. 455-475.

Taniguchi, T., 1967, Landslides in reservoirs, in Proceedings: Jerusalem Academic Press, 3rd Asian Regional Conference on Soil Mechanics and Foundation Engineering, Haifa, September 25-28, v. 1, p. 358-361.

Taylor, G.M., Mahooty, D., and Rayssiguier, J., 2001, Historic dam-modern upgrade, in The future of dams and their reservoirs: 21st Annual USSD Lecture Series, United States Society on Dams, Denver, July 30-August 3, p. 165-176.

Terzaghi, K., 1960a, Report on the proposed storage dam south of Lower Stillwater Lake on the Cheakamus River, B.C., in Bjerrum, L., ed., From theory to practice in soil mechanics I-selections from the writings of Karl Terzaghi: New York, Wiley, p. 395-408.

Terzaghi, K., 1960b, Storage dam founded on landslide debris: Boston Society of Civil Engineers Journal, v. 47, p. 64-94.

Terzaghi, K., 1962, Dam foundation on sheeted granite: Géotechnique, v. 12, p. 199-208.

Thomas, H.H., 1976, The engineering of large dams: Sydney, Wiley, Part I, 376 p.

Tilford, N.R., and Sullivan, J.G., 1981, Lewis River hydroelectric developments, in Geology in the Pacific Northwest: Association of Engineering Geologists Field Trip Guidebook, 24th Annual Meeting, Portland, Oregon, SeptemberOctober, p. 156-185.

Tolmachev, L.V., 1994, Effect of main engineering-geological factors on selection of sites of large dams, in Proceedings: 7th International Congress, International Association of Engineering Geology, Lisbon, September 5-9, v. 2, p. 1,267-1,273.

Tom, E.C.K., Mirafuente, N.T., and Estrella, E., 1976, A stability study of a concrete arch dam rock abutment, in Rock engineering for foundations and slopes: Proceedings of a specialty conference, Boulder, Colo., August 15-18, v. 1, p. 264-282.
Torner, V., and Novosad, S., 1991, The effects of difficult foundation conditions on the conceptual solution and construction of the Slezska Harta Dam, in Transactions: 17th International Congress on Large Dams, International Commission on Large Dams, Vienna, v. 3, p. 719-729.

Tweto, O., Moench, R.H., and Reed, J.C., Jr., 1978, Geologic map of the Leadville $1^{\circ} \times 2^{\circ}$ quadrangle, northwestern Colorado: U.S. Geological Survey Miscellaneous Investigations Series Map I-999, scale 1:250,000.

Vargas, M., 1971, Effectiveness of cut-offs under three earth dams, in Proceedings: 4th Panamerican Conference on Soil Mechanics and Foundation Engineering, San Juan, P.R., June, v. 2, p. 257-273.

Varnes, D.J., 1978, Slope movement types and processes, in Schuster, R.L., and Krizek, R.J., eds., Landslides-analysis and control: National Research Council, Washington, D.C., Transportation Research Board Special Report 176, p. 11-33.

Venzin, C., 1985, Rhodannenberg (Klöntal), in Swiss damsmonitoring and maintenance: Swiss National Committee on Large Dams, Edition for 15th International Congress on Large Dams, International Commission on Large Dams, Lausanne, June 24-28, p. 56-61.

Vichas, C., Skourtis, C., and Stiros, S., 2001, Kinematics of a landslide over the Polyphyton Reservoir (Greece), in Proceedings: 10th FIG (International Federation of Surveyors) Symposium on Deformation Measurements, Orange, Calif., March 19-22, p. 71-74.

Von Thun, J.L., 1985, San Luis Dam upstream slide, in Proceedings: 11th International Conference on Soil Mechanics and Foundation Engineering, San Francisco, August 12-16, v. 5, p. 2,593-2,598.

Von Thun, J.L., 1987, Case studies of landslides and control measures, in Proceedings: 5th International Conference and Field Workshop on Landslides, Christchurch, August 1-12, p. 69-77.

Wahlstrom, E.E., 1974, Dams, dam foundations, and reservoir sites: Amsterdam, Elsevier, 278 p.

Wahlstrom, E.E., and Nichols, T.C., Jr., 1969, The morphology and chronology of a landslide near Dillon Dam, Dillon, Colorado: Engineering Geology, v. 3, p. 149-174.

Walker, F.C., and Harber, W.G., 1961, Design of the Trinity Dam, an earthfill structure 537 feet high, in Transactions: 5th International Congress on Large Dams, International Commission on Large Dams, Paris, May-June, v. 2, p. 743-748. 
Walsh, T.J., Korosec, M.A., Phillips, W.M., Logan, R.L., and Schasse, H.W., 1987, Geologic map of Washington-southwest quadrant: Washington Division of Geology and Earth Resources Geologic Map GM-34, scale 1:625,000.

Walters, R.C.S., 1971, Dam geology (2nd ed.): London, Butterworth's, $470 \mathrm{p}$.

Wang, F.W., Matsumoto, T., and Okuno, T., 2003, The deformation style and affecting factors of the giant Jinnosukedani landslide, Japan, in Bobrowsky, P.T., and Delzeit, R., eds., Program and extended abstracts volume: 2 nd Annual Meeting, Board of Representatives, International Consortium on Landslides, Vancouver, BC, October 28-November 1, p. 49-50.

Watanabe, K., 1985, Foundation grouting of Ohuchi Dam, in Transactions: 18th International Congress on Large Dams, International Commission on Large Dams, Lausanne, June 24-28, v. 3, p. 535-552.

Weaver, K., 1989, Some geologic considerations for dam foundation grouting, in Proceedings: 7th Annual Meeting, Association of State Dam Safety Officials, New Orleans, October, p. 33-38.

Wentworth, C.K., 1929, The geology of dam sites, in Geology and engineering for dams and reservoirs: American Institute of Mining and Metallurgical Engineers Technical Publication 215, p. 78-96.

Weston, R.M., and Jacobs, R., 1997, Golden Cross-technical implications of owning a moving dam, in Proceedings of Technical Groups: New Zealand Society on Large Dams, v. 23 , issue 2 , p. 63-75.

Whipple, J.W., 1992, Geologic map of Glacier National Park, Montana: U.S. Geological Survey Miscellaneous Investigations Series Map I-1508-F, scale 1:100,000.

Widmann, B.L., and Miersemann, U., 2001, Geologic map of the Georgetown quadrangle, Clear Creek County, Colorado: Colorado Geological Survey Open-File Map 01-5, scale $1: 24,000$.

Willis, B., 1928, Report on the geology of St. Francis damsite, Los Angeles County, California: Western Construction News, June 25, v. 3, no. 12, p. 409-413.

Wilshusen, J.P., and Wilson, D., 1981, Tioga-Hammond flood control project, in Geology of Tioga and Bradford Counties, Pennsylvania: Guidebook for the 46th Annual Field Conference of Pennsylvania Geologists, Wellsboro, Pa., October 2-3, p. 77-90.
Wise, W.S., 1961, The geology of the Wind River area, Washington, and the stability relations of celadonite: Baltimore, Md., Johns Hopkins University, Ph.D thesis, 258 p.

Yeend, W.E., 1969, Quaternary geology of the Grand and Battlement Mesas area, Colorado: U.S. Geological Survey Professional Paper 617, $50 \mathrm{p}$.

Yeend, W.E., 1973, Slow-sliding slumps, Grand Mesa, Colorado: The Mountain Geologist, v. 10, no. 1, p. 25-28.

Yesenov, U.Ye., and Degovets, A.S., 1979, Catastrophic mudflow on the Bol'shaya Almatinka River in 1977: Soviet Hydrology—Selected Papers, v. 18, no. 2, p. 158-160.

Yesenov, U.Ye., and Degovets, A.S., 1982, Protection of the city of Alma-Ata from mud-rock flows, in Sheko, A., ed., Landslides and mudflows-Reports of Alma-Ata international seminar: Alma-Ata, October 1981, Centre of International Projects, GKNT, Moscow, p. 454-465.

Záruba, Qu., 1965, Geology of the Orlik Dam site: Water Power, July, p. 273-279.

Záruba, Qu., 1974, Importance of Quaternary events for the geological conditions of building sites, in Centenaire de la Société Géologique de Belgique Colloque Géologie de L'Ingénieur: Liege, September 9-13, p. 259-272.

Záruba, Qu., 1979, The importance of slope movements in dam construction: International Association of Engineering Geology Bulletin 20, p. 158-162.

Záruba, Qu., and Mencl, V., 1976, Engineering geology: Amsterdam, Elsevier, 504 p.

Záruba, Qu., and Mencl, V., 1982, Landslides and their control: Amsterdam, Elsevier, 324 p.

Zhang, X., Liu, T., Wang, Y., and Luo, J., 1985, The main features of debris flows and control structures in Hunshui Gully, Yunnan Province, China, in Proceedings: International Symposium on Erosion, Debris Flow and Disaster Prevention, Tsukuba, Japan, September, p. 181-186.

Zingg, W., 1964, Castiletto, in Behavior of large Swiss dams: Swiss National Committee on Large Dams, p. 285-295.

Published in the Central Region, Denver, Colorado Manuscript approved for publication February 24, 2006 Page layout and cover design by Sharon M. Powers 
Appendix 
Appendix table A. Dam characteristics, relation to landslides, mitigative measures, and cited references.

\begin{tabular}{|c|c|c|c|c|c|c|c|c|c|}
\hline $\begin{array}{l}\text { Country/ } \\
\text { state or } \\
\text { province/ } \\
\text { latitude, } \\
\text { longitude }\end{array}$ & $\begin{array}{l}\text { Dam/river } \\
\text { or stream }\end{array}$ & $\begin{array}{l}\text { Dam type/ } \\
\text { purpose }\end{array}$ & $\begin{array}{l}\text { Year } \\
\text { constructed/ } \\
\text { owner }\end{array}$ & $\begin{array}{l}\text { Height/ } \\
\text { length } \\
\text { (m) }\end{array}$ & $\begin{array}{c}\text { Storage } \\
\text { volume } \\
\left(\mathrm{Mm}^{3}\right)\end{array}$ & $\begin{array}{l}\text { Landslide } \\
\text { type }\end{array}$ & $\begin{array}{l}\text { Landslide } \\
\text { position } \\
\text { relative to } \\
\text { dam }\end{array}$ & Comments & $\begin{array}{l}\text { References/ } \\
\text { sources } \\
\text { of } \\
\text { information }\end{array}$ \\
\hline $\begin{array}{l}\text { Algeria/ } \\
\text { none/ } \\
36.48 \mathrm{~N} \\
5.27 \mathrm{E}\end{array}$ & $\begin{array}{l}\text { Iril-Emda/ } \\
\text { Agrioun River }\end{array}$ & $\begin{array}{l}\text { Rockfill/ } \\
\text { Hydroelec- } \\
\text { tric }\end{array}$ & $\begin{array}{l}\text { 1954/ } \\
\text { Govern- } \\
\text { ment power } \\
\text { company }\end{array}$ & $76 / 575$ & 160 & $\begin{array}{l}\text { Slide in } \\
\text { schist }\end{array}$ & $\begin{array}{l}\text { Left } \\
\text { abutment }\end{array}$ & $\begin{array}{l}\text { Rockfill dam substituted for concrete dam because of } \\
\text { slide. "Dam built on a sliding section and in this case } \\
\text { the dam "supports" landslide and drainage facilities are } \\
\text { provided to raise up the stability." (Tolmachev, 1994) }\end{array}$ & $\begin{array}{l}\text { Lordet and others (1955), } \\
\text { Tolmachev (1994)/None }\end{array}$ \\
\hline $\begin{array}{l}\text { Algeria/ } \\
\text { Skikda/ } \\
36.59 \mathrm{~N} \\
6.90 \mathrm{E}\end{array}$ & $\begin{array}{l}\text { Zardezas/ } \\
\text { Saf-Saf River }\end{array}$ & $\begin{array}{l}\text { Concrete } \\
\text { gravity/ } \\
\text { Irrigation }\end{array}$ & $\begin{array}{l}\text { 1948/ } \\
\text { Federal } \\
\text { government }\end{array}$ & $64 / 242$ & 31 & $\begin{array}{l}\text { Slide in } \\
\text { sandstone }\end{array}$ & $\begin{array}{l}\text { Left } \\
\text { abutment }\end{array}$ & $\begin{array}{l}\text { During construction, } 100,000-\mathrm{m}^{3} \text { slide occurred in } \\
\text { sandstone left abutment. Left end of dam was moved } \\
\text { downstream to stable limestone body. Cylindrical wall } \\
\text { was built in slide mass to allow construction of left part } \\
\text { of dam. In 1970, dam height was raised from } 40 \mathrm{~m} \text { to } \\
64 \mathrm{~m} \text {. Part of the new dam rests on this cylindrical wall, } \\
\text { and thus was built over the landslide. Stability of the } \\
\text { new dam ensured by } 500 \text {-ton anchor cables. }\end{array}$ & $\begin{array}{l}\text { Gignoux and Barbier } \\
\text { (1955, p. 92), Walters } \\
\text { (1971, p. 313), Interna- } \\
\text { tional Commission on } \\
\text { Large Dams (1974, p. } \\
\text { 455), Tolmachev (1994)/ } \\
\text { Christophe Bonnard (oral } \\
\text { commun., 2004) }\end{array}$ \\
\hline $\begin{array}{l}\text { Argentina/ } \\
\text { San } \\
\text { Juan/31.5S, } \\
8.7 \mathrm{~W}\end{array}$ & $\begin{array}{l}\text { Quebrada de } \\
\text { Ullum/San } \\
\text { Juan River }\end{array}$ & $\begin{array}{l}\text { Earthfill/ } \\
\text { Irrigation, } \\
\text { hydro- } \\
\text { electric, } \\
\text { flood } \\
\text { control }\end{array}$ & $\begin{array}{l}\text { 1981/ } \\
\text { Provincial } \\
\text { government }\end{array}$ & $60 / 300$ & 440 & $\begin{array}{l}\text { Rock } \\
\text { slide }\end{array}$ & $\begin{array}{l}\text { Right } \\
\text { abutment }\end{array}$ & $\begin{array}{l}\text { Bedding-plane slips at contacts between sandstone and } \\
\text { claystone were probably caused by tectonic folding. } \\
\text { However, during construction a 260,000- } \mathrm{m}^{3} \text { rock slide } \\
\text { occurred adjacent to the right abutment causing partial } \\
\text { obstruction of the diversion channel. Remedial mea- } \\
\text { sures: (1) buttress at toe of slide, (2) debris removed } \\
\text { from river bottom, (3) excavation slope flattened, (4) } \\
\text { grout curtain, (5) two rows of drains installed in right } \\
\text { bank downstream of the dam. }\end{array}$ & $\begin{array}{l}\text { Pronsato and others } \\
\text { (1973), Figueroa and oth- } \\
\text { ers (1976)/None }\end{array}$ \\
\hline $\begin{array}{l}\text { Australia/ } \\
\text { South } \\
\text { Australia/ } \\
34.87 \mathrm{~S} \text {, } \\
138.78 \mathrm{E}\end{array}$ & $\begin{array}{l}\text { Kangaroo } \\
\text { Creek/ } \\
\text { Torrens } \\
\text { River }\end{array}$ & $\begin{array}{l}\text { Rockfill/ } \\
\text { Water } \\
\text { supply, } \\
\text { flood } \\
\text { control }\end{array}$ & $\begin{array}{l}1969 / \\
\text { Govern- } \\
\text { ment }\end{array}$ & $64 / 131$ & 19 & $\begin{array}{l}\text { Slides, } \\
\text { boulders, } \\
\text { loose } \\
\text { slabs }\end{array}$ & $\begin{array}{l}\text { Both } \\
\text { abutment } \\
\text { areas }\end{array}$ & $\begin{array}{l}\text { In dam-site area, there are scars of two slides on left } \\
\text { bank and one on right. Slides are "block-slide" type. } \\
\text { Also, some scree and boulders. Because of slides, dam } \\
\text { design changed from arch to rockfill. Most of slide ma- } \\
\text { terial probably removed during construction, but some } \\
\text { remains. }\end{array}$ & $\begin{array}{l}\text { Stapledon (1967)/ } \\
\text { None }\end{array}$ \\
\hline $\begin{array}{l}\text { Australia/ } \\
\text { Victoria/ } \\
37.70 \mathrm{~S} \\
145.82 \mathrm{E}\end{array}$ & $\begin{array}{l}\text { O’Shannassy/ } \\
\text { O’Shannassay } \\
\text { River }\end{array}$ & $\begin{array}{l}\text { Earthfill } \\
\text { with re- } \\
\text { inforced } \\
\text { concrete } \\
\text { core wall/ } \\
\text { Water } \\
\text { supply }\end{array}$ & $\begin{array}{l}\text { 1928/ } \\
\text { Municipal } \\
\text { government }\end{array}$ & $34 / 226$ & 4.2 & $\begin{array}{l}\text { Debris } \\
\text { slide }\end{array}$ & $\begin{array}{l}\text { Right } \\
\text { abutment }\end{array}$ & $\begin{array}{l}\text { Right end of dam abuts extensive area of landslide } \\
\text { debris (colluvium). Shears and slickensided surfaces } \\
\text { were found in undisturbed samples of landslide debris. } \\
\text { Concrete corewall was taken to bedrock. }\end{array}$ & $\begin{array}{l}\text { Fell and others (1992, } \\
\text { p. 174), Fell and others } \\
\text { (2000)/consultant's report; } \\
\text { reports of Melbourne and } \\
\text { Metropolitan Board } \\
\text { of Works. }\end{array}$ \\
\hline
\end{tabular}


Appendix table A. Dam characteristics, relation to landslides, mitigative measures, and cited references—Continued.

\begin{tabular}{|c|c|c|c|c|c|c|c|c|c|}
\hline $\begin{array}{l}\text { Country/ } \\
\text { state or } \\
\text { province/ } \\
\text { latitude, } \\
\text { longitude }\end{array}$ & $\begin{array}{l}\text { Dam/river } \\
\text { or stream }\end{array}$ & $\begin{array}{c}\text { Dam type/ } \\
\text { purpose }\end{array}$ & $\begin{array}{c}\text { Year } \\
\text { constructed/ } \\
\text { owner }\end{array}$ & $\begin{array}{l}\text { Height/ } \\
\text { length } \\
(\mathrm{m})\end{array}$ & $\begin{array}{c}\text { Storage } \\
\text { volume } \\
\left(\mathrm{Mm}^{3}\right)\end{array}$ & $\begin{array}{l}\text { Landslide } \\
\text { type }\end{array}$ & $\begin{array}{l}\text { Landslide } \\
\text { position } \\
\text { relative } \\
\text { to dam }\end{array}$ & Comments & $\begin{array}{l}\text { References/ } \\
\text { sources } \\
\text { of } \\
\text { information }\end{array}$ \\
\hline $\begin{array}{l}\text { Australia/ } \\
\text { Tasmania/ } \\
41.66 \mathrm{~S}, \\
146.22 \mathrm{E}\end{array}$ & $\begin{array}{l}\text { Parangana/ } \\
\text { Mersey River }\end{array}$ & $\begin{array}{l}\text { Rockfill/ } \\
\text { Hydro- } \\
\text { electric }\end{array}$ & $\begin{array}{l}\text { 1968/ } \\
\text { Hydroelec- } \\
\text { tric commis- } \\
\text { sion }\end{array}$ & $53 / 189$ & 15 & $\begin{array}{l}\text { Thick } \\
\text { debris- } \\
\text { avalanche } \\
\text { deposits } \\
\text { in valley, } \\
\text { talus on } \\
\text { slopes }\end{array}$ & $\begin{array}{l}\text { Foundation } \\
\text { and both } \\
\text { abutments }\end{array}$ & $\begin{array}{l}\text { Thick ( }>50 \mathrm{~m} \text { ) debris-avalanche deposits associated } \\
\text { with glacial advance form part of foundation. Talus } \\
\text { forms part of surface of both abutments. Talus removed } \\
\text { under dam core on both abutments. Talus fairly imper- } \\
\text { meable; however, extensive cement-grout fan through } \\
\text { talus was included in design of both abutments. }\end{array}$ & $\begin{array}{l}\text { Paterson (1971), Thomas } \\
\text { (1976, p. 156), Fell } \\
\text { and others (1992, p. } \\
\text { 140-141)/None }\end{array}$ \\
\hline $\begin{array}{l}\text { Australia/ } \\
\text { Victoria/ } \\
39.68 . \mathrm{S} \\
145.29 \mathrm{E}\end{array}$ & $\begin{array}{l}\text { Sugarloaf/ } \\
\text { Sugarloaf } \\
\text { Creek }\end{array}$ & $\begin{array}{l}\text { Concrete- } \\
\text { faced } \\
\text { rockfill/ } \\
\text { Water } \\
\text { supply }\end{array}$ & $\begin{array}{l}\text { 1980/Rural } \\
\text { water com- } \\
\text { mission }\end{array}$ & $\begin{array}{l}85 / \\
1,050\end{array}$ & 100 & $\begin{array}{l}\text { "Old land- } \\
\text { slide" }\end{array}$ & $\begin{array}{l}\text { Right } \\
\text { abutment }\end{array}$ & $\begin{array}{l}\text { Suspected old landslide on downstream right abutment } \\
\text { confirmed by trenching. Minor down-dip movements at } \\
\text { left abutment due to past undercutting by erosion. }\end{array}$ & $\begin{array}{l}\text { Fell and others (1992, } \\
\text { p. } 67-70) / \text { None }\end{array}$ \\
\hline $\begin{array}{l}\text { Australia/ } \\
\text { Victoria/ } \\
37.85 \mathrm{~S} \\
146.40 \mathrm{E}\end{array}$ & $\begin{array}{l}\text { Thomson/ } \\
\text { Thomson } \\
\text { River }\end{array}$ & $\begin{array}{l}\text { Rockfill/ } \\
\text { Water sup- } \\
\text { ply, irriga- } \\
\text { tion }\end{array}$ & $\begin{array}{l}\text { 1983/Rural } \\
\text { water com- } \\
\text { mission }\end{array}$ & $\begin{array}{l}166 / \\
1,170\end{array}$ & 1,122 & $\begin{array}{l}\text { Dip-slope } \\
\text { slides }\end{array}$ & $\begin{array}{l}\text { Both } \\
\text { abutments, } \\
\text { right most } \\
\text { serious }\end{array}$ & $\begin{array}{l}\text { Most of slides in sedimentary rocks were removed dur- } \\
\text { ing construction. Remaining disturbed rock stabilized } \\
\text { by } 2.6-\text { million- } \mathrm{m}^{3} \text { rockfill buttress. }\end{array}$ & $\begin{array}{l}\text { Hunter (1982), Fell and } \\
\text { others }(1992, \text { p. } 70-72) / \\
\text { None }\end{array}$ \\
\hline $\begin{array}{l}\text { Australia/ } \\
\text { Victoria/ } \\
36.06 \mathrm{~S} \\
148.27 \mathrm{E}\end{array}$ & $\begin{array}{l}\text { Tooma/ } \\
\text { Tooma River }\end{array}$ & $\begin{array}{l}\text { Earthfill- } \\
\text { rockfill/ } \\
\text { Hydro- } \\
\text { electric }\end{array}$ & $\begin{array}{l}\text { 1961/ } \\
\text { Hydro- } \\
\text { electric } \\
\text { authority }\end{array}$ & $67 / 305$ & 28 & $\begin{array}{l}\text { Sliding on } \\
\text { joints in } \\
\text { granite }\end{array}$ & $\begin{array}{l}\text { Both } \\
\text { abutments, } \\
\text { right the } \\
\text { most seri- } \\
\text { ous }\end{array}$ & $\begin{array}{l}\text { Because past slope movements were not recognized } \\
\text { before construction, there was extra cost for (1) rockfill } \\
\text { buttresses, (2) dental work on open joints, (3) addi- } \\
\text { tion of downstream grout curtain, and (4) rezoning of } \\
\text { embankment. }\end{array}$ & $\begin{array}{l}\text { Hunter (1982), Fell and } \\
\text { others }(1992, \text { p. } 59-64) / \\
\text { None }\end{array}$ \\
\hline $\begin{array}{l}\text { Australia/ } \\
\text { Western Aus- } \\
\text { tralia/ } 32.20 \mathrm{~S} \\
116.06 \mathrm{E}\end{array}$ & $\begin{array}{l}\text { Wungong/ } \\
\text { Wungong } \\
\text { Brook }\end{array}$ & $\begin{array}{l}\text { Earthfill- } \\
\text { rockfill/ } \\
\text { Water } \\
\text { supply }\end{array}$ & $\begin{array}{l}1979 / \text { City } \\
\text { water corpo- } \\
\text { ration }\end{array}$ & $65 / 460$ & 60 & Landslide & $\begin{array}{l}\text { Right } \\
\text { abutment }\end{array}$ & $\begin{array}{l}\text { During construction, landslide was reactivated. Sta- } \\
\text { bilized by addition of rockfill buttress. Filter blanket } \\
\text { placed over slide materials that were left in place under } \\
\text { the rockfill. }\end{array}$ & $\begin{array}{l}\text { Lilly (1986), Fell and } \\
\text { others (1992, p. 64- } \\
\text { 67)/None }\end{array}$ \\
\hline $\begin{array}{l}\text { Austria/ } \\
\text { Tyrol/47.23N, } \\
12.10 \mathrm{E}\end{array}$ & $\begin{array}{l}\text { Durlassboden/ } \\
\text { Gerlosbach }\end{array}$ & $\begin{array}{l}\text { Earthfill/ } \\
\text { Hydro- } \\
\text { electric }\end{array}$ & $\begin{array}{l}\text { 1966/Elec- } \\
\text { tric power } \\
\text { company }\end{array}$ & $83 / 470$ & 53.5 & $\begin{array}{l}\text { Rock slide } \\
\text { overlying } \\
\text { talus }\end{array}$ & $\begin{array}{l}\text { Right } \\
\text { abutment }\end{array}$ & $\begin{array}{l}\text { Right abutment consists of a large block of graphitic } \\
\text { schist and quartzite that had slid down valley wall into } \\
\text { valley deposits of glaciofluvial sands and gravels and } \\
\text { lacustrine silts. Foundation and abutment sealed by } \\
\text { double-row grout curtain extended } 50 \mathrm{~m} \text { into valley } \\
\text { sediment. }\end{array}$ & $\begin{array}{l}\text { Kropatschek and } \\
\text { Rienössl (1967), Záruba } \\
\text { (1974), Rienössl and } \\
\text { Schnelle (1976), Sim- } \\
\text { mler (1977, p. 132-138), } \\
\text { Záruba and Mencl (1982, } \\
\text { p. 242-243), Austrian } \\
\text { National Committee on } \\
\text { Large Dams (1991, p. } \\
\text { 191-194)/None }\end{array}$ \\
\hline
\end{tabular}




\begin{tabular}{|c|c|c|c|c|c|c|c|c|c|}
\hline $\begin{array}{l}\text { Country/ } \\
\text { state or } \\
\text { province/ } \\
\text { latitude, } \\
\text { longitude }\end{array}$ & $\begin{array}{l}\text { Dam/river } \\
\text { or stream }\end{array}$ & $\begin{array}{l}\text { Dam type/ } \\
\text { purpose }\end{array}$ & $\begin{array}{c}\text { Year } \\
\text { constructed/ } \\
\text { owner }\end{array}$ & $\begin{array}{l}\text { Height/ } \\
\text { length } \\
\text { (m) }\end{array}$ & $\begin{array}{c}\text { Storage } \\
\text { volume } \\
\left(\mathrm{Mm}^{3}\right)\end{array}$ & $\begin{array}{l}\text { Landslide } \\
\text { type }\end{array}$ & $\begin{array}{l}\text { Landslide } \\
\text { position } \\
\text { relative to } \\
\text { dam }\end{array}$ & Comments & $\begin{array}{l}\text { References/ } \\
\text { sources } \\
\text { of } \\
\text { information }\end{array}$ \\
\hline $\begin{array}{l}\text { Austria/ } \\
\text { Tyrol/47.12N, } \\
11.87 \mathrm{E}\end{array}$ & $\begin{array}{l}\text { Eberlaste } \\
\text { (Stillup)/ } \\
\text { Zemm River } \\
\text { tributary }\end{array}$ & $\begin{array}{l}\text { Earthfill/ } \\
\text { Hydro- } \\
\text { electric }\end{array}$ & $\begin{array}{l}1968 / \\
\text { Electric } \\
\text { power } \\
\text { company }\end{array}$ & $28 / 480$ & 8.2 & $\begin{array}{l}\text { Rock fall } \\
\text { (talus) }\end{array}$ & $\begin{array}{l}\text { Sides of } \\
\text { foundation }\end{array}$ & $\begin{array}{l}\text { Foundation is talus interfingered with alluvium. } \\
\text { Asphalic-concrete impervious core continuous with } \\
\text { slurry-trench cutoff into talus/alluvium to depth of } \\
52 \mathrm{~m} \text {. In addition, } 50 \text {-m-wide stabilizing fill was built } \\
\text { as a buttress at downstream toe of dam. }\end{array}$ & $\begin{array}{l}\text { Rienössl and Schnelle } \\
\text { (1976), Simmler (1977, } \\
\text { p. 143-148), Austrian } \\
\text { National Committee } \\
\text { on Large Dams (1991), } \\
\text { Leobacher (2000)/None }\end{array}$ \\
\hline $\begin{array}{l}\text { Austria/ } \\
\text { Carinthia/ } \\
46.52 \mathrm{~N} \\
14.47 \mathrm{E}\end{array}$ & $\begin{array}{l}\text { Freibach/ } \\
\text { Drau River } \\
\text { tributary }\end{array}$ & $\begin{array}{l}\text { Rockfill/ } \\
\text { Hydro- } \\
\text { electric }\end{array}$ & $\begin{array}{l}\text { 1958/Electric } \\
\text { power } \\
\text { company }\end{array}$ & $41 / 150$ & 5.5 & $\begin{array}{l}\text { Rock slide } \\
\text { in } \\
\text { limestone }\end{array}$ & $\begin{array}{l}\text { Left } \\
\text { abutment }\end{array}$ & $\begin{array}{l}\text { Concrete diaphragm constructed through slide. } \\
\text { During reservoir filling, diaphragm leaked. Grout } \\
\text { curtain added, but leaked. Second grout curtain } \\
\text { successfully added, supplemented by sealing with } \\
\text { chemical materials. }\end{array}$ & $\begin{array}{l}\text { Simmler (1977, } \\
\text { p. 109-114)/None }\end{array}$ \\
\hline $\begin{array}{l}\text { Austria/ } \\
\text { Tyrol/46.95N, } \\
10.75 \mathrm{E}\end{array}$ & $\begin{array}{l}\text { Gepatsch/ } \\
\text { Faggenbach } \\
\text { River }\end{array}$ & $\begin{array}{l}\text { Rockfill/ } \\
\text { Hydro- } \\
\text { electric }\end{array}$ & $\begin{array}{l}\text { 1965/Electric } \\
\text { power } \\
\text { company }\end{array}$ & $153 / 600$ & 140 & $\begin{array}{l}\text { Rock fall } \\
\text { (talus) }\end{array}$ & $\begin{array}{l}\text { Left } \\
\text { abutment }\end{array}$ & $\begin{array}{l}\text { "On the left slope the rock is covered with a layer of } \\
\text { talus and redeposited boulder clay up to } 25 \text { m thick" } \\
\text { (Lauffer and Schober, 1964). "Mass movement was } \\
\text { seen to occur on the left valley slope already during } \\
\text { first partial filling. Thorough investigation and model } \\
\text { studies proved this to be the reactivation of an old rock } \\
\text { slide" (Simmler, 1977, p. 120). Apparently, the only } \\
\text { material removed was in the upstream zone of the dam } \\
\text { foundation/left abutment. }\end{array}$ & $\begin{array}{l}\text { Lauffer and Schober } \\
\text { (1964), Schober (1970), } \\
\text { Simmler (1977, } \\
\text { p. 120-124)/None }\end{array}$ \\
\hline $\begin{array}{l}\text { Bolivia/Tarija/ } \\
21.7 \mathrm{~S}, 64.8 \mathrm{~W}\end{array}$ & $\begin{array}{l}\text { San Jacinto/ } \\
\text { Tolomosa } \\
\text { River }\end{array}$ & $\begin{array}{l}\text { Concrete } \\
\text { arch/ } \\
\text { Irrigation, } \\
\text { hydro- } \\
\text { electric, } \\
\text { recreation }\end{array}$ & $\begin{array}{l}\text { Under } \\
\text { construction } \\
(1998) / \\
\text { Electric } \\
\text { power } \\
\text { consortium }\end{array}$ & $49 / 100$ & 54.3 & $\begin{array}{l}\text { Wedge } \\
\text { failure, } \\
\text { topple }\end{array}$ & $\begin{array}{l}\text { Left } \\
\text { abutment }\end{array}$ & $\begin{array}{l}\text { Landslide in slate, sandstone, and overlying lacustrine } \\
\text { sediments is one of several along left valley wall. } \\
\text { Reactivated during construction. Left abutment rebuilt } \\
\text { by filling adits with concrete. }\end{array}$ & $\begin{array}{l}\text { Riemer (1995)/W. Riemer } \\
\text { (written commun., 1998) }\end{array}$ \\
\hline $\begin{array}{l}\text { Brazil/ } \\
\text { Paraíba/6.89S, } \\
\text { 38.39W }\end{array}$ & $\begin{array}{l}\text { Engenheiro } \\
\text { Avidos } \\
\text { (Piranhas)/ } \\
\text { Piranhas } \\
\text { River }\end{array}$ & $\begin{array}{l}\text { Zoned } \\
\text { rockfill/ } \\
\text { Irrigation, } \\
\text { water } \\
\text { supply, } \\
\text { flood } \\
\text { control }\end{array}$ & $\begin{array}{l}\text { 1936/Federal } \\
\text { government }\end{array}$ & $47 / 359$ & 255 & $\begin{array}{l}\text { Block } \\
\text { slump, } \\
\text { talus }\end{array}$ & $\begin{array}{l}\text { Both } \\
\text { abutments }\end{array}$ & $\begin{array}{l}\text { Right abutment is weathered-gneiss block slump; left } \\
\text { abutment is talus. Both are fairly impervious; however, } \\
\text { toe-drain system was installed on each abutment. }\end{array}$ & $\begin{array}{l}\text { DNOCS (1982, } \\
\text { p. 58-65)/None }\end{array}$ \\
\hline
\end{tabular}


Appendix table A. Dam characteristics, relation to landslides, mitigative measures, and cited references-Continued.

\begin{tabular}{|c|c|c|c|c|c|c|c|c|c|}
\hline $\begin{array}{l}\text { Country/ } \\
\text { state or } \\
\text { province/ } \\
\text { latitude, } \\
\text { longitude }\end{array}$ & $\begin{array}{l}\text { Dam/river } \\
\text { or stream }\end{array}$ & $\begin{array}{l}\text { Dam type/ } \\
\text { purpose }\end{array}$ & $\begin{array}{l}\text { Year } \\
\text { constructed/ } \\
\text { owner }\end{array}$ & $\begin{array}{l}\text { Height/ } \\
\text { length } \\
\text { (m) }\end{array}$ & $\begin{array}{c}\text { Storage } \\
\text { volume } \\
\left(\mathrm{Mm}^{3}\right)\end{array}$ & $\begin{array}{l}\text { Landslide } \\
\text { type }\end{array}$ & $\begin{array}{l}\text { Landslide } \\
\text { position } \\
\text { relative to } \\
\text { dam }\end{array}$ & Comments & $\begin{array}{l}\text { References/ } \\
\text { sources } \\
\text { of } \\
\text { information }\end{array}$ \\
\hline $\begin{array}{l}\text { Brazil/Sao Paolo/ } \\
21.60 \mathrm{~S}, 46.95 \mathrm{~W}\end{array}$ & $\begin{array}{l}\text { Euclides da } \\
\text { Cunha/ } \\
\text { Pardo River }\end{array}$ & $\begin{array}{l}\text { Earthfill/ } \\
\text { Hydroelectric }\end{array}$ & $\begin{array}{l}1960 \text { (rebuilt } \\
\text { 1977)/Electric } \\
\text { power } \\
\text { company }\end{array}$ & $92 / 312$ & 13.4 & $\begin{array}{l}\text { "Ancient } \\
\text { land- } \\
\text { slides" }\end{array}$ & $\begin{array}{l}\text { Both } \\
\text { abutments }\end{array}$ & $\begin{array}{l}\text { "Ancient landslides" in form of clayey } \\
\text { "residual talus" found at both abutments. } \\
\text { Cutoff trenches filled with impervious soil } \\
\text { were placed through talus, followed by grout } \\
\text { curtains placed through the trenches. Dam } \\
\text { failed at right end in } 1977 \text { due to flood over- } \\
\text { topping. Slide material at right abutment may } \\
\text { have been factor. }\end{array}$ & $\begin{array}{l}\text { Vargas (1971), Brazil- } \\
\text { ian Committee on Large } \\
\text { Dams (1982, } \\
\text { p. 411-435)/None }\end{array}$ \\
\hline $\begin{array}{l}\text { Bulgaria/Plovdiv/ } \\
42.04 \mathrm{~N}, 24.47 \mathrm{E}\end{array}$ & $\begin{array}{l}\text { Krichim/ } \\
\text { Vacha River }\end{array}$ & $\begin{array}{l}\text { Concrete } \\
\text { buttress- } \\
\text { gravity/ } \\
\text { Hydroelectric }\end{array}$ & $\begin{array}{l}\text { 1972/ Govern- } \\
\text { ment }\end{array}$ & $105 / 269$ & 18 & Rock slide & $\begin{array}{l}\text { Right } \\
\text { abutment }\end{array}$ & $\begin{array}{l}\text { "Ancient" rock slide }(80 \mathrm{~m} \text { thick; total vol- } \\
\left.\text { ume: } 10.5 \text { million } \mathrm{m}^{3}\right) \text { in gneiss and marble } \\
\text { extends along the valley wall from } 500 \mathrm{~m} \\
\text { above dam to river bottom. }\end{array}$ & Demirev (1979)/None \\
\hline $\begin{array}{l}\text { Canada/ } \\
\text { British Columbia/ } \\
49.98 \mathrm{~N}, 123.15 \mathrm{~W}\end{array}$ & $\begin{array}{l}\text { Cheakamus/ } \\
\text { Cheakamus } \\
\text { River }\end{array}$ & $\begin{array}{l}\text { Earthfill- } \\
\text { rockfill/ } \\
\text { Hydroelectric }\end{array}$ & $\begin{array}{l}\text { 1957/ Electric } \\
\text { power } \\
\text { company }\end{array}$ & $28 / 683$ & 52.4 & $\begin{array}{l}\text { Debris } \\
\text { avalanche- } \\
\text { debris flow }\end{array}$ & $\begin{array}{l}\text { Most of } \\
\text { foundation }\end{array}$ & $\begin{array}{l}\text { Foundation is "Rubble Creek Wash," a debris } \\
\text { avalanche-debris flow that occurred in 1855- } \\
56 . \text { Permeability and stability of this material } \\
\text { were studied before construction. Dam has } \\
\text { functioned well. Greatest hazard may be } \\
\text { slight possibility of another avalanche-flow } \\
\text { occurrence, sending wave over top of dam. }\end{array}$ & $\begin{array}{l}\text { Terzaghi (1960a, b), } \\
\text { Moore and Mathews } \\
\text { (1978), Eisbacher } \\
\text { (1983), Legget and } \\
\text { Karrow (1983, p. 23-14 } \\
\text { to 23-15), Evans and } \\
\text { Savigny (1994)/None }\end{array}$ \\
\hline $\begin{array}{l}\text { Canada/ Sas- } \\
\text { katchewan/ } \\
51.27 \mathrm{~N}, 106.88 \mathrm{~W}\end{array}$ & $\begin{array}{l}\text { Gardiner/ } \\
\text { South } \\
\text { Saskatchewan } \\
\text { River }\end{array}$ & $\begin{array}{l}\text { Earthfill/ } \\
\text { Irrigation, } \\
\text { water supply, } \\
\text { hydroelectric }\end{array}$ & $\begin{array}{l}\text { 1968/ } \\
\text { Provincial } \\
\text { government }\end{array}$ & $69 / 5090$ & 9,867 & $\begin{array}{l}\text { Massive } \\
\text { slump in } \\
\text { shale }\end{array}$ & $\begin{array}{l}\text { Left- } \\
\text { abutment } \\
\text { area }\end{array}$ & $\begin{array}{l}\text { Large-scale prehistoric slide in shale of left } \\
\text { abutment. Local failure during construction } \\
\text { led to removal of much of unstable shale } \\
\text { under central zone of dam. Extensive berms } \\
\text { added and abutment slopes flattened. }\end{array}$ & $\begin{array}{l}\text { Ringheim (1964), Jaspar } \\
\text { and Peters (1979), } \\
\text { Peters and Long (1981)/ } \\
\text { None }\end{array}$ \\
\hline $\begin{array}{l}\text { Canada/Quebec/ } \\
50.9 \mathrm{~N}, 66.9 \mathrm{~W}\end{array}$ & $\begin{array}{l}\text { Sainte } \\
\text { Marguerite- } \\
\text { 3/Sainte } \\
\text { Marguerite } \\
\text { River }\end{array}$ & $\begin{array}{l}\text { Earthfill- } \\
\text { rockfill/ } \\
\text { Hydroelectric }\end{array}$ & $\begin{array}{l}\text { 1998/Electric } \\
\text { power com- } \\
\text { pany }\end{array}$ & $171 / 378$ & $\begin{array}{c}\text { Not } \\
\text { known }\end{array}$ & $\begin{array}{l}\text { Rock fall } \\
\text { (talus) and } \\
\text { rock slide }\end{array}$ & $\begin{array}{l}\text { Left } \\
\text { abutment, } \\
\text { left founda- } \\
\text { tion, right } \\
\text { abutment }\end{array}$ & $\begin{array}{l}\text { Core of dam is in excavation to gneiss bed- } \\
\text { rock. Under left dam shell, talus was consid- } \\
\text { ered to be acceptable as foundation and was } \\
\text { not removed. Large right-abutment slide mass } \\
\text { mostly left in place during construction; mass } \\
\text { settled }<15 \mathrm{~cm} \text { under weight of }>40 \mathrm{~m} \text { of fill. }\end{array}$ & $\begin{array}{l}\text { Rattue and others (1999, } \\
\text { 2000)/Interview with } \\
\text { consultant }\end{array}$ \\
\hline
\end{tabular}


Appendix table A. Dam characteristics, relation to landslides, mitigative measures, and cited references-Continued.

\begin{tabular}{|c|c|c|c|c|c|c|c|c|c|}
\hline $\begin{array}{l}\text { Country/ } \\
\text { state or } \\
\text { province/ } \\
\text { latitude, } \\
\text { longitude }\end{array}$ & $\begin{array}{l}\text { Dam/river } \\
\text { or stream }\end{array}$ & $\begin{array}{c}\text { Dam type/ } \\
\text { purpose }\end{array}$ & $\begin{array}{l}\text { Year } \\
\text { constructed/ } \\
\text { owner }\end{array}$ & $\begin{array}{l}\text { Height/ } \\
\text { length } \\
\text { (m) }\end{array}$ & $\begin{array}{l}\text { Storage } \\
\text { volume } \\
\left(\mathrm{Mm}^{3}\right)\end{array}$ & $\begin{array}{c}\text { Landslide } \\
\text { type }\end{array}$ & $\begin{array}{l}\text { Landslide } \\
\text { position } \\
\text { relative to } \\
\text { dam }\end{array}$ & Comments & $\begin{array}{l}\text { References/ } \\
\text { sources } \\
\text { of } \\
\text { information }\end{array}$ \\
\hline $\begin{array}{l}\text { Canada/British } \\
\text { Columbia/ } \\
49.44 \mathrm{~N}, 122.97 \mathrm{~W}\end{array}$ & $\begin{array}{l}\text { Seymour } \\
\text { Falls/ Sey- } \\
\text { mour River }\end{array}$ & $\begin{array}{l}\text { Earthfill- } \\
\text { concrete/ } \\
\text { Water supply }\end{array}$ & $\begin{array}{l}\text { 1961/City } \\
\text { water district }\end{array}$ & $30 / 457$ & 25.3 & $\begin{array}{l}\text { Debris- } \\
\text { flow cone }\end{array}$ & $\begin{array}{l}\text { Right } \\
\text { abutment }\end{array}$ & $\begin{array}{l}\text { Debris-flow cone from tributary stream forms } \\
\text { right abutment of embankment dam. Imper- } \\
\text { vious upstream blanket prevents seepage } \\
\text { through debris cone. }\end{array}$ & $\begin{array}{l}\text { Ripley and Campbell } \\
\text { (1963), Heidstra and } \\
\text { others (1995)/None }\end{array}$ \\
\hline $\begin{array}{l}\text { Chile/VII Region/ } \\
36.17 \mathrm{~S}, 71.25 \mathrm{~W}\end{array}$ & $\begin{array}{l}\text { Bullileo/ Bul- } \\
\text { lileo River }\end{array}$ & $\begin{array}{l}\text { Earthfill/ } \\
\text { Irrigation }\end{array}$ & $\begin{array}{l}1949 / \\
\text { Irrigation } \\
\text { association }\end{array}$ & $70 / 260$ & 60 & $\begin{array}{l}\text { "Great } \\
\text { slide" }\end{array}$ & Left abutment & $\begin{array}{l}\text { Very large slide in moraine deposits forms left } \\
\text { abutment. Dam has had piping problems in } \\
\text { moraine of right abutment (1982), but no dif- } \\
\text { ficulty with left abutment. }\end{array}$ & $\begin{array}{l}\text { Castro and Garces } \\
\text { (1985)/L. Valenzuela } \\
\text { (oral commun., 1996) }\end{array}$ \\
\hline $\begin{array}{l}\text { Chile/V Región } \\
\text { (Valparaíso)/ } \\
\text { 32.97S, } 70.25 \mathrm{~W}\end{array}$ & $\begin{array}{l}\text { Los Leones/ } \\
\text { Los Leones } \\
\text { Stream }\end{array}$ & $\begin{array}{l}\text { Earthfill/ } \\
\text { Mine tailings } \\
\text { disposal }\end{array}$ & $\begin{array}{l}1998 \text { (final } \\
\text { stage)/ } \\
\text { Mining } \\
\text { company }\end{array}$ & $160 / 500$ & $\begin{array}{c}\text { Not } \\
\text { known }\end{array}$ & $\begin{array}{l}\text { Debris } \\
\text { slide, } \\
\text { earth slide }\end{array}$ & $\begin{array}{l}\text { Right } \\
\text { abutment }\end{array}$ & $\begin{array}{l}\text { Slide not recognized originally; however, it } \\
\text { has had no effect on dam performance. Thus, } \\
\text { no remedial measures installed. }\end{array}$ & $\begin{array}{l}\text { None/L. Valenzuela } \\
\text { (written commun., } \\
\text { 1996) }\end{array}$ \\
\hline $\begin{array}{l}\text { Chile/Santiago } \\
\text { Metropolitan } \\
\text { Region/ } \\
\text { 33.65S, 70.08W }\end{array}$ & $\begin{array}{l}\text { Yeso/Yeso } \\
\text { River }\end{array}$ & $\begin{array}{l}\text { Earthfill/ } \\
\text { Water supply }\end{array}$ & $\begin{array}{l}\text { 1967/Local } \\
\text { government }\end{array}$ & $61 / 350$ & 250 & $\begin{array}{l}\text { Debris } \\
\text { flow and } \\
\text { rock fall }\end{array}$ & $\begin{array}{l}\text { Both } \\
\text { abutments (?) }\end{array}$ & $\begin{array}{l}\text { Unacceptable seepage through both abut- } \\
\text { ments. Extensive cement grouting in } 1979-81 \text {. } \\
\text { Debris-flow materials probably also present in } \\
\text { foundation. }\end{array}$ & $\begin{array}{l}\text { Moreno and others } \\
\text { (1991)/L. Valenzuela } \\
\text { (written commun., } \\
\text { 1996) }\end{array}$ \\
\hline $\begin{array}{l}\text { China/Yunnan/ } \\
26.25 \mathrm{~N}, 103.15 \mathrm{E}\end{array}$ & $\begin{array}{l}\text { Hunshui } \\
\text { Gully debris- } \\
\text { retention dam } \\
\text { \#4/Hunshui } \\
\text { Stream }\end{array}$ & $\begin{array}{l}\text { Stone and } \\
\text { concrete/ } \\
\text { Debris } \\
\text { retention }\end{array}$ & $\begin{array}{l}\text { 1978-81(?)/ } \\
\text { District } \\
\text { government }\end{array}$ & $\begin{array}{l}16 / \text { Not } \\
\text { known }\end{array}$ & $\begin{array}{c}\text { Not } \\
\text { known }\end{array}$ & $\begin{array}{l}\text { Debris } \\
\text { flow }\end{array}$ & $\begin{array}{l}\text { Entire } \\
\text { foundation }\end{array}$ & $\begin{array}{l}\text { Debris-retention dam \#4 is one of a series built } \\
\text { from } 1978 \text { to about } 1981 \text { to retain debris-flow } \\
\text { deposits in Hunshui Gully. Present status not } \\
\text { known. }\end{array}$ & $\begin{array}{l}\text { Li and Luo (1981), } \\
\text { Zhang and others } \\
\text { (1985)/None }\end{array}$ \\
\hline $\begin{array}{l}\text { China/Anhui/ } \\
31.66 \mathrm{~N}, 115.88 \mathrm{E}\end{array}$ & $\begin{array}{l}\text { Meishan/ } \\
\text { Shihe River }\end{array}$ & $\begin{array}{l}\text { Concrete mul- } \\
\text { tiple arch/ } \\
\text { Flood control, } \\
\text { irrigation, } \\
\text { hydroelectric }\end{array}$ & $\begin{array}{l}\text { 1956/ } \\
\text { Government }\end{array}$ & $88 / 443$ & 2,275 & $\begin{array}{l}\text { Rock } \\
\text { slide } \\
\text { along } \\
\text { joints } \\
\text { in granite }\end{array}$ & $\begin{array}{l}\text { Right } \\
\text { abutment }\end{array}$ & $\begin{array}{l}\text { In 1962, movement occurred along joints in } \\
\text { right abutment. Apparently, these joints had } \\
\text { shown some movement before construction. } \\
\text { Remedial measures: (1) grout curtain, (2) } \\
\text { impervious membrane upstream of right abut- } \\
\text { ment, (3) anchors, and (4) buttresses. }\end{array}$ & $\begin{array}{l}\text { Qi (1986), Chinese } \\
\text { National Committee } \\
\text { on Large Dams (1987, } \\
\text { p. 134-138)/None }\end{array}$ \\
\hline
\end{tabular}


Appendix table A. Dam characteristics, relation to landslides, mitigative measures, and cited references-Continued.

\begin{tabular}{|c|c|c|c|c|c|c|c|c|c|}
\hline $\begin{array}{l}\text { Country/ } \\
\text { state } \\
\text { or province/ } \\
\text { latitude, } \\
\text { longitude }\end{array}$ & $\begin{array}{l}\text { Dam/river } \\
\text { or stream }\end{array}$ & $\begin{array}{l}\text { Dam type/ } \\
\text { purpose }\end{array}$ & $\begin{array}{l}\text { Year } \\
\text { constructed/ } \\
\text { owner }\end{array}$ & $\begin{array}{l}\text { Height/ } \\
\text { length } \\
\text { (m) }\end{array}$ & $\begin{array}{l}\text { Storage } \\
\text { volume } \\
\left(\mathrm{Mm}^{3}\right)\end{array}$ & $\begin{array}{l}\text { Landslide } \\
\text { type }\end{array}$ & $\begin{array}{l}\text { Landslide } \\
\text { position } \\
\text { relative to } \\
\text { dam }\end{array}$ & Comments & $\begin{array}{l}\text { References/ } \\
\text { sources } \\
\text { of information }\end{array}$ \\
\hline $\begin{array}{l}\text { China/Yunnan/ } \\
\text { near Sichuan } \\
\text { border }\end{array}$ & $\begin{array}{l}\text { Wuping/ } \\
\text { Papa River }\end{array}$ & $\begin{array}{l}\text { Rockfill/ } \\
\text { Hydroelectric }\end{array}$ & $\begin{array}{l}\text { Under } \\
\text { construction/ } \\
\text { Government }\end{array}$ & $49 / 215$ & 49.9 & Earth slide & $\begin{array}{l}\text { Right } \\
\text { end of } \\
\text { foundation }\end{array}$ & $\begin{array}{l}\text { Slide deposit (volume: } 1.2 \text { million } \mathrm{m}^{3} \text { ) is in } \\
\text { right end of foundation. Remedial measures: } \\
\text { (1) } 14 \text {-m-high rockfill platform constructed } \\
\text { on slide as preload, (2) vertical rock piles } \\
\text { inserted through slide deposit. }\end{array}$ & $\begin{array}{l}\text { Chen and others (2001)/ } \\
\text { Chinese engineers }\end{array}$ \\
\hline $\begin{array}{l}\text { Cyprus/Limassol/ } \\
34.72 \mathrm{~N}, 32.99 \mathrm{E}\end{array}$ & $\begin{array}{l}\text { Polemidhia/ } \\
\text { Garyllis River }\end{array}$ & $\begin{array}{l}\text { Earthfill/ } \\
\text { Irrigation }\end{array}$ & $\begin{array}{l}\text { 1965/ } \\
\text { Government }\end{array}$ & $45 / 196$ & 3.9 & $\begin{array}{l}\text { Rock } \\
\text { slide, rock } \\
\text { fall }\end{array}$ & $\begin{array}{l}\text { Left } \\
\text { abutment }\end{array}$ & $\begin{array}{l}\text { Left abutment consists of limestone and chalk } \\
\text { rock slide-rock fall blocks. Permeability of } \\
\text { landslide material led to installation of grout } \\
\text { curtain. }\end{array}$ & $\begin{array}{l}\text { Konteatis (1974, } \\
\text { p. 202-208)/None }\end{array}$ \\
\hline $\begin{array}{l}\text { Czech Republic/ } \\
\text { South Moravia/ } \\
49.12 \mathrm{~N}, 16.16 \mathrm{E}\end{array}$ & $\begin{array}{l}\text { Dalešice/ } \\
\text { Jihlava River }\end{array}$ & $\begin{array}{l}\text { Rockfill/ } \\
\text { Hydroelectric, } \\
\text { water supply, } \\
\text { irrigation }\end{array}$ & $\begin{array}{l}\text { 1979/ } \\
\text { Government }\end{array}$ & $100 / 330$ & 127.3 & Rock slide & $\begin{array}{l}\text { Right abut- } \\
\text { ment }\end{array}$ & $\begin{array}{l}\text { Construction caused } 150,000-\mathrm{m}^{3} \text { reactivation } \\
\text { of rock slide in amphibolite zone of right } \\
\text { abutment. Slide stabilized by (1) rockfill but- } \\
\text { tress at toe of slope, (2) unloading of upper } \\
\text { part of slide, and (3) use of rock anchors. }\end{array}$ & $\begin{array}{l}\text { Mencl (1977), Hrdy } \\
\text { and Mares (1978), } \\
\text { Záruba (1979), Záruba } \\
\text { and Mencl (1982, } \\
\text { p. 245-246), Hobst } \\
\text { and Zajíc, (1983, } \\
\text { p. 399-401)/S. Novosad } \\
\text { (written commun., } \\
\text { 1996) }\end{array}$ \\
\hline $\begin{array}{l}\text { Czech Republic/ } \\
\text { North Bohemia/ } \\
50.36 \mathrm{~N} 13.42 \mathrm{~N}\end{array}$ & $\begin{array}{l}\text { Nechranice/ } \\
\text { Ohre River }\end{array}$ & $\begin{array}{l}\text { Earthfill/ } \\
\text { Flood control, } \\
\text { hydroelectric, } \\
\text { irrigation, } \\
\text { recreation, water } \\
\text { supply }\end{array}$ & $\begin{array}{l}\text { 1968/ } \\
\text { Government }\end{array}$ & $\begin{array}{l}52 / \\
3,280\end{array}$ & 287.6 & $\begin{array}{l}\text { Slides in } \\
\text { claystone }\end{array}$ & $\begin{array}{l}\text { Right abut- } \\
\text { ment }\end{array}$ & $\begin{array}{l}\text { Pleistocene bank erosion had caused slides to } \\
\text { depth of } 15 \mathrm{~m} \text { in claystone of right abutment. } \\
\text { Angle of slope immediately upstream of right } \\
\text { abutment flattened to increase stability. Imper- } \\
\text { vious clay-cement cutoff installed though } \\
\text { right abutment to reduce seepage. }\end{array}$ & $\begin{array}{l}\text { Grosman and Lejsek } \\
(1965), \text { Czechoslovak } \\
\text { National Dam Commit- } \\
\text { tee (1967, } \\
\text { p. 31), Horský and } \\
\text { Spanilá (1997)/None }\end{array}$ \\
\hline $\begin{array}{l}\text { Czech Republic/ } \\
\text { North Moravia/ } \\
49.90 \mathrm{~N}, 17.57 \mathrm{E}\end{array}$ & $\begin{array}{l}\text { Slezska } \\
\text { Harta/ } \\
\text { Moravice } \\
\text { River }\end{array}$ & $\begin{array}{l}\text { Rockfill/ } \\
\text { Water supply, } \\
\text { flood control }\end{array}$ & $\begin{array}{l}\text { 1997/ } \\
\text { Government }\end{array}$ & $65 / 540$ & 217.5 & $\begin{array}{l}\text { "Ancient" } \\
\text { slides in } \\
\text { shale and } \\
\text { basalt }\end{array}$ & $\begin{array}{l}\text { Both abut- } \\
\text { ments }\end{array}$ & $\begin{array}{l}\text { During construction, movement occurred in } \\
\text { shale slide of left abutment and creep in basalt } \\
\text { blocks of right abutment. Remediation: (1) } \\
\text { excavation of upper left slope, (2) buttress at } \\
\text { toe of left slope, and (3) surface/subsurface } \\
\text { drainage. }\end{array}$ & $\begin{array}{l}\text { Novosad (1990), Torner } \\
\text { and Novosad (1991), } \\
\text { Novosad and Novosad } \\
(1993) / \text { None }\end{array}$ \\
\hline
\end{tabular}


Appendix table A. Dam characteristics, relation to landslides, mitigative measures, and cited references-Continued.

\begin{tabular}{|c|c|c|c|c|c|c|c|c|c|}
\hline $\begin{array}{l}\text { Country/ } \\
\text { state } \\
\text { or province/ } \\
\text { latitude, } \\
\text { longitude }\end{array}$ & $\begin{array}{l}\text { Dam/river } \\
\text { or stream }\end{array}$ & $\begin{array}{l}\text { Dam type/ } \\
\text { purpose }\end{array}$ & $\begin{array}{l}\text { Year } \\
\text { constructed/ } \\
\text { owner }\end{array}$ & $\begin{array}{l}\text { Height/ } \\
\text { length } \\
\text { (m) }\end{array}$ & $\begin{array}{c}\text { Storage } \\
\text { volume } \\
\left(\mathrm{Mm}^{3}\right)\end{array}$ & $\begin{array}{l}\text { Landslide } \\
\text { type }\end{array}$ & $\begin{array}{l}\text { Landslide } \\
\text { position } \\
\text { relative to } \\
\text { dam }\end{array}$ & Comments & $\begin{array}{l}\text { References/ } \\
\text { sources } \\
\text { of } \\
\text { information }\end{array}$ \\
\hline $\begin{array}{l}\text { Czech Republic/ } \\
\text { North Moravia/ } \\
49.77 \mathrm{~N}, 18.52 \mathrm{E}\end{array}$ & $\begin{array}{l}\text { Terlicko/ } \\
\text { Stonávka } \\
\text { River }\end{array}$ & $\begin{array}{l}\text { Earthfill/ } \\
\text { Water supply, } \\
\text { flood control }\end{array}$ & $\begin{array}{l}\text { 1962/ } \\
\text { Government }\end{array}$ & $28 / 617$ & 24.4 & $\begin{array}{l}\text { Slide in } \\
\text { clay shale }\end{array}$ & $\begin{array}{l}\text { Right } \\
\text { abutment }\end{array}$ & $\begin{array}{l}\text { Right abutment is in toe of huge clay-shale slide. } \\
\text { Chemical and cement grout curtains placed. Stabil- } \\
\text { ity increased by construction of buttress on right } \\
\text { side. Movement continues (as of 1996). }\end{array}$ & $\begin{array}{l}\text { Czechoslovak } \\
\text { National Dam Com- } \\
\text { mittee (1967, } \\
\text { p. 28)/S. Novosad } \\
\text { (written commun., } \\
\text { 1996) }\end{array}$ \\
\hline $\begin{array}{l}\text { Czech Republic/ } \\
\text { North Moravia/ } \\
49.73 \mathrm{~N}, 18.45 \mathrm{E}\end{array}$ & $\begin{array}{l}\text { Zermanice/ } \\
\text { Lucina River }\end{array}$ & $\begin{array}{l}\text { Concrete } \\
\text { gravity/Water } \\
\text { supply, flood } \\
\text { control }\end{array}$ & $\begin{array}{l}\text { 1958/ } \\
\text { Government }\end{array}$ & $37 / 617$ & 27.2 & $\begin{array}{l}\text { Slide in } \\
\text { flysch }\end{array}$ & $\begin{array}{l}\text { Right } \\
\text { abutment }\end{array}$ & $\begin{array}{l}\text { Slide of entire hillside of clay shales with layers of } \\
\text { sandstone and weathered teschenite. Reactivated } \\
\text { during construction. Right abutment continues to } \\
\text { slowly deform by bulging. }\end{array}$ & $\begin{array}{l}\text { Czechoslovak } \\
\text { National } \\
\text { Dam Committee } \\
\text { (1967, p. 16)/S. } \\
\text { Novosad } \\
\text { (written commun., } \\
\text { 1996) }\end{array}$ \\
\hline $\begin{array}{l}\text { Ecuador/Azuay/ } \\
2.68 \mathrm{~S}, 78.63 \mathrm{~W}\end{array}$ & $\begin{array}{l}\text { Daniel } \\
\text { Palacios } \\
\text { (Amaluza)/ } \\
\text { Paute River }\end{array}$ & $\begin{array}{l}\text { Concrete arch- } \\
\text { gravity/ } \\
\text { Hydroelectric }\end{array}$ & $\begin{array}{l}\text { 1983/Federal } \\
\text { government }\end{array}$ & $167 / 420$ & 120 & Rock slide & $\begin{array}{l}\text { Left } \\
\text { abutment }\end{array}$ & $\begin{array}{l}\text { Reactivation during construction; probably part of } \\
\text { toe of large prehistoric slide in decomposed grano- } \\
\text { diorite. Remedial measures: (1) active part removed } \\
\text { and (2) concrete beams with prestressed anchors } \\
\text { placed at the abutment. }\end{array}$ & $\begin{array}{l}\text { Tom and others } \\
(1976), \text { Riemer } \\
(1995) / \\
\text { W. Riemer (written } \\
\text { commun., 1998) }\end{array}$ \\
\hline $\begin{array}{l}\text { Ecuador/Guayas/ } \\
1.0 \mathrm{~S}, 79.8 \mathrm{~W}\end{array}$ & $\begin{array}{l}\text { Daule Peripa/ } \\
\text { Daule River }\end{array}$ & $\begin{array}{l}\text { Earthfill/ } \\
\text { Irrigation, } \\
\text { flood control, } \\
\text { water supply, } \\
\text { hydroelectric }\end{array}$ & $\begin{array}{l}\text { Uncertain (un- } \\
\text { der construc- } \\
\text { tion in 1988)/ } \\
\text { Government }\end{array}$ & $78 / 246$ & 6,000 & $\begin{array}{l}\text { Small } \\
\text { shale } \\
\text { slide due } \\
\text { to stress } \\
\text { relief }\end{array}$ & $\begin{array}{l}\text { Right } \\
\text { abutment }\end{array}$ & $\begin{array}{l}\text { Reactivation of slide during construction. Blocks } \\
\text { of tuffaceous sediments slid on sheared shale layer. } \\
\text { Cracks were filled with concrete and additional } \\
\text { filters were placed. }\end{array}$ & $\begin{array}{l}\text { None/W. Riemer } \\
\text { (written commun., } \\
\text { 1998) }\end{array}$ \\
\hline $\begin{array}{l}\text { France/ } \\
\text { Corrèze/ } \\
45.41 \mathrm{~N}, 2.49 \mathrm{E}\end{array}$ & $\begin{array}{l}\text { Bort/ } \\
\text { Dordogne } \\
\text { River }\end{array}$ & $\begin{array}{l}\text { Concrete grav- } \\
\text { ity arch/ } \\
\text { Hydroelectric }\end{array}$ & $\begin{array}{l}1951 / \\
\text { Hydroelectric } \\
\text { company }\end{array}$ & $131 / 390$ & 477 & $\begin{array}{l}\text { Bedding } \\
\text { plane slips } \\
\text { in gneiss } \\
\text { and schist }\end{array}$ & $\begin{array}{l}\text { Both } \\
\text { abutments }\end{array}$ & $\begin{array}{l}\text { Bedding-surface slips formed weak clay layers } \\
\text { between gneiss and underlying schist beds. During } \\
\text { construction, a slide of several thousand cubic } \\
\text { meters occurred in left abutment; slide area was } \\
\text { bridged by concrete arch. Right abutment: zone of } \\
\text { crushed material removed and replaced by rein- } \\
\text { forced concrete. }\end{array}$ & $\begin{array}{l}\text { Walters }(1971 \text {, } \\
\text { p. 193-200)/None }\end{array}$ \\
\hline
\end{tabular}


Appendix table A. Dam characteristics, relation to landslides, mitigative measures, and cited references-Continued.

\begin{tabular}{|c|c|c|c|c|c|c|c|c|c|}
\hline $\begin{array}{l}\text { Country/ } \\
\text { state } \\
\text { or province/ } \\
\text { latitude, } \\
\text { longitude }\end{array}$ & $\begin{array}{l}\text { Dam/river } \\
\text { or stream }\end{array}$ & $\begin{array}{l}\text { Dam type/ } \\
\text { purpose }\end{array}$ & $\begin{array}{c}\text { Year } \\
\text { constructed/ } \\
\text { owner }\end{array}$ & $\begin{array}{l}\text { Height/ } \\
\text { length } \\
\text { (m) }\end{array}$ & $\begin{array}{c}\text { Storage } \\
\text { volume } \\
\left(\mathrm{Mm}^{3}\right)\end{array}$ & $\begin{array}{l}\text { Landslide } \\
\text { type }\end{array}$ & $\begin{array}{l}\text { Landslide } \\
\text { position } \\
\text { relative to } \\
\text { dam }\end{array}$ & Comments & $\begin{array}{l}\text { References/ } \\
\text { sources } \\
\text { of } \\
\text { information }\end{array}$ \\
\hline $\begin{array}{l}\text { France/Basse } \\
\text { Alps/ } \\
43.85 \mathrm{~N}, 6.54 \mathrm{E}\end{array}$ & $\begin{array}{l}\text { Chaudanne/ } \\
\text { Verdon } \\
\text { River }\end{array}$ & $\begin{array}{l}\text { Concrete thin } \\
\text { arch/ } \\
\text { Hydroelectric }\end{array}$ & $\begin{array}{l}1952 / \\
\text { Federal } \\
\text { government } \\
\text { hydroelectric } \\
\text { company }\end{array}$ & $71 / 95$ & 16 & $\begin{array}{l}\text { Rock slide } \\
\text { on joints }\end{array}$ & $\begin{array}{l}\text { Right } \\
\text { abutment }\end{array}$ & $\begin{array}{l}\text { During construction, a limestone block (vol. } \\
\sim 1,200 \mathrm{~m}^{3} \text { ) broke off along steeply-dipping, } \\
\text { pre-existing fault, and was removed. Another } \\
4,000 \mathrm{~m}^{3} \text { was stabilized by rock anchors, con- } \\
\text { crete buttress, and cement grout. }\end{array}$ & $\begin{array}{l}\text { Haffen (1955), Walters } \\
(1971, \text { p. 139-140), } \\
\text { Anderson and Trigg } \\
\text { (1976, p. 31-32), Hobst } \\
\text { and Zajíc (1983, } \\
\text { p. 405-406)/None }\end{array}$ \\
\hline $\begin{array}{l}\text { France/Hautes } \\
\text { Alpes/ } \\
44.46 \mathrm{~N}, 6.24 \mathrm{E}\end{array}$ & $\begin{array}{l}\text { Serre-Ponçon/ } \\
\text { Durance } \\
\text { River }\end{array}$ & $\begin{array}{l}\text { Earthfill/ } \\
\text { Hydroelectric, } \\
\text { irrigation }\end{array}$ & $\begin{array}{l}\text { 1960/ Elec- } \\
\text { tricité de } \\
\text { France }\end{array}$ & $129 / 600$ & 1.2 & $\begin{array}{l}\text { Talus } \\
\text { (scree) }\end{array}$ & $\begin{array}{l}\text { Both } \\
\text { abutments } \\
\text { and } \\
\text { foundation }\end{array}$ & $\begin{array}{l}\text { Large deposit of talus interbedded with al- } \\
\text { luvium was left in place in foundation of right } \\
\text { end of dam. Seepage prevented by injection of } \\
\text { impervious cutoff to bedrock. } 500,000 \mathrm{~m}^{3} \text { of } \\
\text { scree removed from left abutment. }\end{array}$ & $\begin{array}{l}\text { Ischy and Haffen } \\
\text { (1955), Cabanius and } \\
\text { Maigre (1958)/None }\end{array}$ \\
\hline $\begin{array}{l}\text { Greece/ } \\
\text { Sterea Hellas/ } \\
38.66 \mathrm{~N}, 21.87 \mathrm{E}\end{array}$ & $\begin{array}{l}\text { Evinos/ } \\
\text { Evinos River }\end{array}$ & $\begin{array}{l}\text { Earthfill/ } \\
\text { Water supply }\end{array}$ & $\begin{array}{l}\text { 1998/ } \\
\text { Government }\end{array}$ & $124 / 640$ & 113 & $\begin{array}{l}\text { Slide in } \\
\text { collu- } \\
\text { vium and } \\
\text { weathered } \\
\text { flysch }\end{array}$ & $\begin{array}{l}\text { Just above } \\
\text { left } \\
\text { abutment }\end{array}$ & $\begin{array}{l}\text { Abutment excavation reactivated part of large } \\
\text { slide in left abutment immediately upstream } \\
\text { from spillway entrance, barely in contact with } \\
\text { dam. Remedial measures: (1) pumping wells, } \\
\text { (2) replacing part of sliding surface with free- } \\
\text { draining material, and (3) removing part of } \\
\text { upper slide. }\end{array}$ & $\begin{array}{l}\text { Dounias and others } \\
\text { (1996)/None }\end{array}$ \\
\hline $\begin{array}{l}\text { Greece/Fokis/ } \\
38.53 \mathrm{~N}, 22.12 \mathrm{E}\end{array}$ & $\begin{array}{l}\text { Mornos/ } \\
\text { Mornos River }\end{array}$ & $\begin{array}{l}\text { Earthfill/ } \\
\text { Water supply }\end{array}$ & $\begin{array}{l}\text { 1979/ } \\
\text { Government }\end{array}$ & $126 / 815$ & 780 & Rock slide & $\begin{array}{l}\text { Right } \\
\text { abutment }\end{array}$ & $\begin{array}{l}\text { Pleistocene rock slide }\left(\mathrm{vol} . \sim 25 \text { million } \mathrm{m}^{3}\right) \text { is } \\
\text { at right end of dam. Dam acts as buttress, and } \\
\text { toe buttress }\left(8 \text { million } \mathrm{m}^{3}\right) \text { was installed along } \\
\text { reservoir shore. }\end{array}$ & $\begin{array}{l}\text { Schetelig (1989), } \\
\text { Riemer (1995)/W. } \\
\text { Riemer (written } \\
\text { commun., 1998) }\end{array}$ \\
\hline $\begin{array}{l}\text { Greece/West } \\
\text { Macedonia/ } \\
40.30 \mathrm{~N}, 22.10 \mathrm{E}\end{array}$ & $\begin{array}{l}\text { Polyphyton/ } \\
\text { Aliakmon } \\
\text { River }\end{array}$ & $\begin{array}{l}\text { Rockfill/ } \\
\text { Hydroelectric }\end{array}$ & $\begin{array}{l}\text { 1974/ } \\
\text { Government }\end{array}$ & $112 / 640$ & 1,939 & $\begin{array}{l}\text { Slide in } \\
\text { colluvium } \\
\text { and gneiss }\end{array}$ & $\begin{array}{l}\text { Both } \\
\text { abutments }\end{array}$ & $\begin{array}{l}\text { Several slides in area. Left-bank downstream } \\
\text { slide barely contacts toe of dam. Alexis slide } \\
\left(20 \text { million } \mathrm{m}^{3}\right) \text { lies directly above right abut- } \\
\text { ment but is not in contact with dam because } \\
\text { design was adjusted to remove vital structures } \\
\text { from slide area. Surface drains and drainage } \\
\text { adit added. }\end{array}$ & $\begin{array}{l}\text { Riemer (1995), Riemer } \\
\text { and others (1996), } \\
\text { Vichas and others } \\
\text { (2001)/W. Riemer, } \\
\text { (written commun., } \\
\text { 1998) }\end{array}$ \\
\hline
\end{tabular}




\begin{tabular}{|c|c|c|c|c|c|c|c|c|c|}
\hline $\begin{array}{l}\text { Country/ } \\
\text { state } \\
\text { or province/ } \\
\text { latitude, } \\
\text { longitude }\end{array}$ & $\begin{array}{l}\text { Dam/river } \\
\text { or stream }\end{array}$ & $\begin{array}{l}\text { Dam type/ } \\
\text { purpose }\end{array}$ & $\begin{array}{l}\text { Year } \\
\text { constructed/ } \\
\text { owner }\end{array}$ & $\begin{array}{l}\text { Height/ } \\
\text { length } \\
(\mathrm{m})\end{array}$ & $\begin{array}{c}\text { Storage } \\
\text { volume } \\
\left(\mathrm{Mm}^{3}\right)\end{array}$ & $\begin{array}{c}\text { Landslide } \\
\text { type }\end{array}$ & $\begin{array}{l}\text { Landslide } \\
\text { position } \\
\text { relative to } \\
\text { dam }\end{array}$ & Comments & $\begin{array}{l}\text { References/ } \\
\text { sources } \\
\text { of } \\
\text { information }\end{array}$ \\
\hline $\begin{array}{l}\text { Greece/East } \\
\text { Macedonia/ } \\
41.3 \mathrm{~N}, 24.3 \mathrm{E}\end{array}$ & $\begin{array}{l}\text { Thissavros/ } \\
\text { Nestos River }\end{array}$ & $\begin{array}{l}\text { Rockfill/ } \\
\text { Hydroelectric }\end{array}$ & $\begin{array}{l}\text { 1986/ } \\
\text { Government }\end{array}$ & $170 / 480$ & 705 & $\begin{array}{l}\text { Slide in } \\
\text { gneiss }\end{array}$ & Not known & $\begin{array}{l}\text { During excavation, slide reactivation occurred. } \\
\text { Part of dam sits on slide mass in gneiss. Extensive } \\
\text { remediation installed. Currently, no indication of } \\
\text { movement. }\end{array}$ & $\begin{array}{l}\text { Krapp and Pant- } \\
\text { zartzis (1989), } \\
\text { Riemer (1995)/W. } \\
\text { Riemer (written } \\
\text { commun., 1998) }\end{array}$ \\
\hline $\begin{array}{l}\text { India/ } \\
\text { Uttar Pradesh/ } \\
30.6 \mathrm{~N}, 77.8 \mathrm{E}\end{array}$ & $\begin{array}{l}\text { Ichari/ } \\
\text { Tons River }\end{array}$ & $\begin{array}{l}\text { Concrete } \\
\text { gravity/ } \\
\text { Hydroelectric }\end{array}$ & $\begin{array}{l}\text { 1975/State } \\
\text { government }\end{array}$ & $59 / 155$ & 14.3 & $\begin{array}{l}\text { Slide in } \\
\text { slates and } \\
\text { quartzites }\end{array}$ & Left abutment & $\begin{array}{l}\text { Depth of slide debris in left abutment was } 33-63 \\
\text { m. To stabilize left abutment: (1) reinforced } \\
\text { concrete cutoff wall tied to sound quartzite band } \\
\text { and (2) } 45 \text {-m-long concrete diaphragm ties dam to } \\
\text { sound rock. }\end{array}$ & $\begin{array}{l}\text { Jalote and others } \\
(1975), \text { Lavania } \\
(1988) \text { /None }\end{array}$ \\
\hline $\begin{array}{l}\text { India/West } \\
\text { Bengal/ } \\
27.1 \mathrm{~N}, 88.9 \mathrm{E}\end{array}$ & $\begin{array}{l}\text { Jaldhaka } \\
\text { Stage I/ } \\
\text { Jaldhaka } \\
\text { River }\end{array}$ & $\begin{array}{l}\text { Diversion } \\
\text { wier/ } \\
\text { Hydroelectric }\end{array}$ & $\begin{array}{l}\text { 1967/State } \\
\text { government }\end{array}$ & $18 / 98$ & $\begin{array}{c}\text { Not } \\
\text { known }\end{array}$ & $\begin{array}{l}\text { Rock and } \\
\text { debris } \\
\text { slides in } \\
\text { schist and } \\
\text { gneiss }\end{array}$ & $\begin{array}{l}\text { Right } \\
\text { abutment }\end{array}$ & $\begin{array}{l}\text { "Huge rock-cum-debris slides occurred from the } \\
\text { right abutment during the 1964-66 monsoons, } \\
\text { covering the partly constructed intake structure" } \\
\text { (Roy, 1975). Remedial measures: (1) abutment } \\
\text { was "dressed" and benched at suitable intervals, } \\
\text { (2) retaining and "breast" walls were constructed } \\
\text { to prevent further slides, and (3) slide area was } \\
\text { grouted. }\end{array}$ & $\begin{array}{l}\text { Roy }(1975), \text { Chat- } \\
\text { terjee }(1979) / \text { None }\end{array}$ \\
\hline $\begin{array}{l}\text { India/Himachal } \\
\text { Pradesh/ } \\
31.80 \mathrm{~N}, 76.95 \mathrm{E}\end{array}$ & $\begin{array}{l}\text { Pandoh/ } \\
\text { Beas River }\end{array}$ & $\begin{array}{l}\text { Earthfill-rock- } \\
\text { fill/ Irrigation, } \\
\text { hydroelectric }\end{array}$ & $\begin{array}{l}1977 / \\
\text { Federal gov- } \\
\text { ernment }\end{array}$ & $76 / 411$ & 41 & $\begin{array}{l}\text { Slump } \\
\text { mass and } \\
\text { shear zone } \\
\text { in phyllite }\end{array}$ & $\begin{array}{l}\text { Both } \\
\text { abutments }\end{array}$ & $\begin{array}{l}\text { Proposed concrete dam changed to rockfill because } \\
\text { of slump mass (right abutment) and shear zone (left } \\
\text { abutment). Shear zone excavated to 3-m depth; } \\
\text { trench backfilled with impervious material. Right } \\
\text { axis of dam moved upstream to prevent failure } \\
\text { into reservoir. Prevention measures: (1) 15-m-deep } \\
\text { concrete cutoff through slump, (2) horizontal-drain } \\
\text { system, and (3) buttressing by dam. }\end{array}$ & $\begin{array}{l}\text { Srivastava and } \\
\text { Agarwal (1975)/ } \\
\text { None }\end{array}$ \\
\hline $\begin{array}{l}\text { India/Himachal } \\
\text { Pradesh/ } \\
31.98 \mathrm{~N}, 75.94 \mathrm{E}\end{array}$ & $\begin{array}{l}\text { Pong/ } \\
\text { Beas River }\end{array}$ & $\begin{array}{l}\text { Earthfill/ } \\
\text { Irrigation, } \\
\text { hydroelectric }\end{array}$ & $\begin{array}{l}\text { 1974/State } \\
\text { government }\end{array}$ & $\begin{array}{l}133 / \\
1,950\end{array}$ & 8,570 & $\begin{array}{l}\text { Block } \\
\text { glide in } \\
\text { clay shale }\end{array}$ & $\begin{array}{l}\text { Left } \\
\text { abutment }\end{array}$ & $\begin{array}{l}\text { Large, inactive slide in left abutment in vicinity of } \\
\text { tunnel intakes. Many open cracks ("glide cracks"). } \\
\text { Remedial measures: (1) shallow unsound rock re- } \\
\text { moved from core foundation, (2) concrete caissons } \\
\text { installed as "keys," and (3) toe buttresses installed } \\
\text { at river level. }\end{array}$ & $\begin{array}{l}\text { Bhatnagar and } \\
\text { Parkash (1967), } \\
\text { Jalote and Tikku } \\
\text { (1975), Central } \\
\text { Board of Irrigation } \\
\text { and Power (1979, } \\
\text { p. 183-235)/None }\end{array}$ \\
\hline
\end{tabular}


Appendix table A. Dam characteristics, relation to landslides, mitigative measures, and cited references-Continued.

\begin{tabular}{|c|c|c|c|c|c|c|c|c|c|}
\hline $\begin{array}{l}\text { Country/ } \\
\text { state } \\
\text { or province/ } \\
\text { latitude, } \\
\text { longitude }\end{array}$ & $\begin{array}{l}\text { Dam/river } \\
\text { or stream }\end{array}$ & $\begin{array}{l}\text { Dam type/ } \\
\text { purpose }\end{array}$ & $\begin{array}{l}\text { Year } \\
\text { constructed/ } \\
\text { owner }\end{array}$ & $\begin{array}{l}\text { Height/ } \\
\text { length } \\
(\mathrm{m})\end{array}$ & $\begin{array}{c}\text { Storage } \\
\text { volume } \\
\left(\mathrm{Mm}^{3}\right)\end{array}$ & $\begin{array}{l}\text { Landslide } \\
\text { type }\end{array}$ & $\begin{array}{l}\text { Landslide } \\
\text { position } \\
\text { relative to } \\
\text { dam }\end{array}$ & Comments & $\begin{array}{l}\text { References/ } \\
\text { sources } \\
\text { of } \\
\text { information }\end{array}$ \\
\hline $\begin{array}{l}\text { India/Rajasthan/ } \\
\text { 24.93N, 75.56E }\end{array}$ & $\begin{array}{l}\text { Ranaptrap } \\
\text { Sagar/ Cham- } \\
\text { bal River }\end{array}$ & $\begin{array}{l}\text { Masonry/ } \\
\text { Irrigation, } \\
\text { hydroelectric }\end{array}$ & $\begin{array}{l}\text { 1967/State } \\
\text { government }\end{array}$ & $\begin{array}{l}58 / \\
1,143\end{array}$ & 290 & $\begin{array}{l}\text { Slumps in } \\
\text { shale }\end{array}$ & $\begin{array}{l}\text { Left } \\
\text { abutment }\end{array}$ & $\begin{array}{l}\text { Deep-seated slumping in shale and cracking in } \\
\text { sandstone. Remedial measures: (1) flattening } \\
\text { slopes, (2) clay blankets with filters, (3) area } \\
\text { grouting, (4) anchors, (5) retaining wall, and (6) } \\
\text { drainage. }\end{array}$ & Sanganeria (1975)/None \\
\hline $\begin{array}{l}\text { India/Jammu and } \\
\text { Kashmir/ } \\
\sim 32.8 \mathrm{~N}, 74.8 \mathrm{~W} \\
\text { (near Dyangarh) }\end{array}$ & $\begin{array}{l}\text { Salal/ } \\
\text { Chinab River }\end{array}$ & $\begin{array}{l}\text { Rockfill/ } \\
\text { Hydroelectric }\end{array}$ & $\begin{array}{l}\text { 1986/State } \\
\text { government }\end{array}$ & $118 / 630$ & 1.5 & $\begin{array}{l}\text { Deep- } \\
\text { seated } \\
\text { rock } \\
\text { slump in } \\
\text { dolomite }\end{array}$ & $\begin{array}{l}\text { Right } \\
\text { abutment }\end{array}$ & $\begin{array}{l}\text { "...the right abutment...has a deep seated } \\
\text { huge slump of rock overlain by thick cover of } \\
\text { overburden" (Sen and others, 1987). Treatment } \\
\text { of abutment: (1) removal of slump mass in core } \\
\text { contact area, (2) areal and curtain grouting, (3) } \\
\text { concrete cutoff, and (4) "wrap around" of core } \\
\text { material covering the slump zone. }\end{array}$ & $\begin{array}{l}\text { Sen and others (1987)/ } \\
\text { None }\end{array}$ \\
\hline $\begin{array}{l}\text { Iran/Khuzestan/ } \\
32.3 \mathrm{~N}, 48.9 \mathrm{E}\end{array}$ & $\begin{array}{l}\text { Upper Got- } \\
\text { vand/ Karun } \\
\text { River }\end{array}$ & $\begin{array}{l}\text { Rockfill/ } \\
\text { Hydroelectric }\end{array}$ & $\begin{array}{l}\text { Under } \\
\text { construc- } \\
\text { tion }(2004) / \\
\text { Government } \\
\text { power com- } \\
\text { pany }\end{array}$ & $170 / 760$ & 4,500 & $\begin{array}{l}\text { Right } \\
\text { abutment: } \\
\text { rock } \\
\text { topple; } \\
\text { left abut- } \\
\text { ment: rock } \\
\text { slide }\end{array}$ & $\begin{array}{l}\text { Both } \\
\text { abutments }\end{array}$ & $\begin{array}{l}\text { Both abutments include dislocated rock masses } \\
\text { in Bakhtyari Fm. (conglomerate). Right abut- } \\
\text { ment mass apparently is a rock topple; dislo- } \\
\text { cated left-abutment mass is a rock slide. }\end{array}$ & None/Consultants \\
\hline $\begin{array}{l}\text { Italy/Sicily } \\
37.83 \mathrm{~N}, 14.58 \mathrm{E}\end{array}$ & $\begin{array}{l}\text { Ancipa/ } \\
\text { Troina River }\end{array}$ & $\begin{array}{l}\text { Cellular } \\
\text { concrete } \\
\text { gravity/Irriga- } \\
\text { tion, hydro- } \\
\text { electric }\end{array}$ & $\begin{array}{l}\text { 1953/Govern- } \\
\text { ment }\end{array}$ & $105 / 253$ & 30.4 & $\begin{array}{l}\text { Thick } \\
\text { talus }\end{array}$ & $\begin{array}{l}\text { Foundation } \\
\text { and right } \\
\text { abutment }\end{array}$ & $\begin{array}{l}\text { "...bottom and right shoulder are covered with } \\
\text { talus." Concrete diaphragm } 4 \mathrm{~m} \text { thick sunk } \\
\text { through talus to bedrock at right abutment. }\end{array}$ & $\begin{array}{l}\text { ANIDEL (1961, v. 1, p. } \\
\text { 304-306)/None }\end{array}$ \\
\hline $\begin{array}{l}\text { Italy/Val } \\
\text { D'Aosta/ } \\
45.63 \mathrm{~N}, 7.06 \mathrm{E}\end{array}$ & $\begin{array}{l}\text { Beauregard/ } \\
\text { Dora di Val- } \\
\text { grisenche }\end{array}$ & $\begin{array}{l}\text { Concrete } \\
\text { arch-gravity/ } \\
\text { Hydroelectric }\end{array}$ & $\begin{array}{l}\text { 1960/Govern- } \\
\text { ment }\end{array}$ & $132 / 394$ & 74 & $\begin{array}{l}\text { Slide in } \\
\text { schist }\end{array}$ & $\begin{array}{l}\text { Left } \\
\text { abutment }\end{array}$ & $\begin{array}{l}\text { Large slide in mica schist moved onto alluvium. } \\
\text { During first filling of reservoir the landslide } \\
\text { accelerated, attaining a displacement rate of } \\
20 \mathrm{~mm} / \mathrm{month} \text { producing cracks in lower third } \\
\text { of the dam. Glaciofluvial sediments from } \\
\text { deep pocket under slide had to be replaced by } \\
\text { concrete. Also, water-tight membrane placed by } \\
\text { cement injection. }\end{array}$ & $\begin{array}{l}\text { ANIDEL (1961, v. 1, } \\
\text { p. 313-315), Desio } \\
\text { (1973, p. 99-101), } \\
\text { Záruba (1974), Záruba } \\
\text { and Mencl (1982, p. } \\
\text { 243-244), Picarelli and } \\
\text { Russo (2004))/None }\end{array}$ \\
\hline
\end{tabular}


Appendix table A. Dam characteristics, relation to landslides, mitigative measures, and cited references-Continued.

\begin{tabular}{|c|c|c|c|c|c|c|c|c|c|}
\hline $\begin{array}{l}\text { Country/ } \\
\text { state } \\
\text { or province/ } \\
\text { latitude, } \\
\text { longitude }\end{array}$ & $\begin{array}{l}\text { Dam/river } \\
\text { or stream }\end{array}$ & $\begin{array}{l}\text { Dam type/ } \\
\text { purpose }\end{array}$ & $\begin{array}{c}\text { Year } \\
\text { constructed/ } \\
\text { owner }\end{array}$ & $\begin{array}{l}\text { Height/ } \\
\text { length } \\
\text { (m) }\end{array}$ & $\begin{array}{l}\text { Storage } \\
\text { volume } \\
\left(\mathrm{Mm}^{3}\right)\end{array}$ & $\begin{array}{l}\text { Landslide } \\
\text { type }\end{array}$ & $\begin{array}{l}\text { Landslide } \\
\text { position } \\
\text { relative to } \\
\text { dam }\end{array}$ & Comments & $\begin{array}{l}\text { References/ } \\
\text { sources } \\
\text { of } \\
\text { information }\end{array}$ \\
\hline $\begin{array}{l}\text { Italy/Umbria/ } \\
43.16 \mathrm{~N}, 12.60 \mathrm{E}\end{array}$ & $\begin{array}{l}\text { Casanuova/ } \\
\text { Chiascio River }\end{array}$ & $\begin{array}{l}\text { Earthfill/ } \\
\text { Irrigation, } \\
\text { water supply }\end{array}$ & $\begin{array}{l}\text { 1994/Irriga- } \\
\text { tion district }\end{array}$ & $88 / 444$ & 224 & $\begin{array}{l}\text { Trans- } \\
\text { lational } \\
\text { slide }\end{array}$ & $\begin{array}{l}\text { Right } \\
\text { abutment }\end{array}$ & $\begin{array}{l}\text { Slide is } 70-80 \mathrm{~m} \text { thick. Water level increase in } \\
\text { reservoir during construction (1991) caused 20-mil- } \\
\text { lion- } \mathrm{m}^{3} \text { slide reactivation. Remedial measures: (1) } \\
\text { reduced rate of reservoir filling and (2) installed } \\
\text { physical remediation. }\end{array}$ & $\begin{array}{l}\text { Catalano and others } \\
(2000) \text {, Picarelli } \\
\text { and Russo (2004)/ } \\
\text { Italian National } \\
\text { Dam Service }\end{array}$ \\
\hline $\begin{array}{l}\text { Italy/Reggio } \\
\text { Emilia/ } \\
44.29 \mathrm{~N}, 10.37 \mathrm{E}\end{array}$ & $\begin{array}{l}\text { Ozola/Ozola } \\
\text { River }\end{array}$ & $\begin{array}{l}\text { Concrete mul- } \\
\text { tiple arch/ } \\
\text { Hydroelectric }\end{array}$ & $\begin{array}{l}\text { 1929/Govern- } \\
\text { ment }\end{array}$ & $25 / 96$ & 0.061 & $\begin{array}{l}\text { Slide in } \\
\text { thick talus }\end{array}$ & $\begin{array}{l}\text { Left } \\
\text { abutment }\end{array}$ & $\begin{array}{l}\text { Concrete cutoff at left abutment was sunk through } \\
39.5 \mathrm{~m} \text { of talus by means of superimposed tunnels. }\end{array}$ & $\begin{array}{l}\text { ANIDEL }(1961, \mathrm{v} \\
\text { 7, p. 76-88)/None }\end{array}$ \\
\hline $\begin{array}{l}\text { Italy/Trentino A. } \\
\text { Adige/ } \\
46.30 \mathrm{~N}, 10.68 \mathrm{E}\end{array}$ & $\begin{array}{l}\text { Pian Palù/ } \\
\text { Noce Torrent }\end{array}$ & $\begin{array}{l}\text { Concrete } \\
\text { blocks/Hydro- } \\
\text { electric }\end{array}$ & $\begin{array}{l}\text { 1959/Govern- } \\
\text { ment }\end{array}$ & $52 / 180$ & 16.1 & $\begin{array}{l}\text { Deep- } \\
\text { seated } \\
\text { slump }\end{array}$ & $\begin{array}{l}\text { Left } \\
\text { abutment }\end{array}$ & $\begin{array}{l}\text { Deep-seated rotational slump (sackung?) in mica } \\
\text { schist. To avoid consequences of possible move- } \\
\text { ment of abutment, dam type was chosen consisting } \\
\text { of concrete blocks separated by sand. Concrete cut- } \\
\text { off wall placed to depth of } 30 \mathrm{~m} \text { in landslide debris } \\
\text { of left abutment during construction. }\end{array}$ & $\begin{array}{l}\text { ANIDEL (1961, v. } \\
\text { 1, p. 18-19), Desio } \\
\text { (1973, p. 899-900), } \\
\text { Picarelli and Russo } \\
\text { (2004)/None }\end{array}$ \\
\hline $\begin{array}{l}\text { Italy/Reggio } \\
\text { Emilia/ } \\
43.88 \mathrm{~N}, 12.09 \mathrm{E}\end{array}$ & $\begin{array}{l}\text { Quarto sul } \\
\text { Savio/Savio } \\
\text { River }\end{array}$ & $\begin{array}{l}\text { Concrete } \\
\text { gravity/ } \\
\text { Hydroelectric }\end{array}$ & $\begin{array}{l}\text { 1925/Govern- } \\
\text { ment }\end{array}$ & $21 / 59$ & 6.67 & $\begin{array}{l}\text { Landslide } \\
\text { in flysch }\end{array}$ & $\begin{array}{l}\text { Left } \\
\text { abutment }\end{array}$ & $\begin{array}{l}\text { Dam was built partially on } 1812 \text { natural landslide } \\
\text { dam derived from clayey sandstone. A few years } \\
\text { after construction, problems occurred in operating } \\
\text { gates of the dam. }\end{array}$ & $\begin{array}{l}\text { ANIDEL }(1953, \mathrm{v} \text {. } \\
6, \text { p. 234), Picarelli } \\
\text { and Russo (2004)/ } \\
\text { None }\end{array}$ \\
\hline $\begin{array}{l}\text { Italy/Modena/ } \\
44.27 \mathrm{~N}, 10.73 \mathrm{E}\end{array}$ & $\begin{array}{l}\text { Riolunato/ } \\
\text { Scoltenna } \\
\text { River }\end{array}$ & $\begin{array}{l}\text { Concrete } \\
\text { multiple arch/ } \\
\text { Hydroelectric }\end{array}$ & $\begin{array}{l}\text { 1920/Govern- } \\
\text { ment }\end{array}$ & $27 / 90$ & 0.06 & $\begin{array}{l}\text { "Mass- } \\
\text { flow" }\end{array}$ & $\begin{array}{l}\text { Right } \\
\text { abutment }\end{array}$ & $\begin{array}{l}\text { Monitoring from 1979-93 indicated total creep of } \\
\text { right abutment of } 17 \mathrm{~cm} \text { toward the dam. There } \\
\text { is no failure surface; therefore, authors classified } \\
\text { movement as "flow." Probably continuation of pre- } \\
\text { dam movement. }\end{array}$ & $\begin{array}{l}\text { Castelucci and } \\
\text { others (1999), } \\
\text { Picarelli and Russo } \\
\text { (2004)/None }\end{array}$ \\
\hline
\end{tabular}


Appendix table A. Dam characteristics, relation to landslides, mitigative measures, and cited references-Continued.

\begin{tabular}{|c|c|c|c|c|c|c|c|c|c|}
\hline $\begin{array}{l}\text { Country/ } \\
\text { state } \\
\text { or province/ } \\
\text { latitude, } \\
\text { longitude }\end{array}$ & $\begin{array}{l}\text { Dam/river } \\
\text { or stream }\end{array}$ & $\begin{array}{c}\text { Dam type/ } \\
\text { purpose }\end{array}$ & $\begin{array}{l}\text { Year } \\
\text { constructed/ } \\
\text { owner }\end{array}$ & $\begin{array}{l}\text { Height/ } \\
\text { length } \\
\text { (m) }\end{array}$ & $\begin{array}{l}\text { Storage } \\
\text { volume } \\
\left(\mathrm{Mm}^{3}\right)\end{array}$ & $\begin{array}{l}\text { Landslide } \\
\text { type }\end{array}$ & $\begin{array}{l}\text { Landslide } \\
\text { position } \\
\text { relative to } \\
\text { dam }\end{array}$ & Comments & $\begin{array}{l}\text { References/ } \\
\text { sources } \\
\text { of } \\
\text { information }\end{array}$ \\
\hline $\begin{array}{l}\text { Italy/Sicily/ } \\
\text { 37.96N, 13.37E }\end{array}$ & $\begin{array}{l}\text { Rossella/ } \\
\text { Rossella } \\
\text { River }\end{array}$ & $\begin{array}{l}\text { Earthfill/ } \\
\text { Water supply, } \\
\text { irrigation }\end{array}$ & $\begin{array}{l}\text { 1965/Irriga- } \\
\text { tion district }\end{array}$ & $27 / 336$ & 17.2 & $\begin{array}{l}\text { Earthflow } \\
\text { in clay } \\
\text { shale }\end{array}$ & $\begin{array}{l}\text { Left } \\
\text { abutment }\end{array}$ & $\begin{array}{l}\text { Pre-existing earthflow in flysch of the left abut- } \\
\text { ment was reactivated during construction in } 1961 . \\
\text { In 1997-98, sudden reactivation again occurred } \\
\text { causing cracks in cutoff wall at dam toe and } \\
\text { displacements on dam crest. Remedial measure: } \\
\text { lowering reservoir level. Monitoring program: } \\
\text { inclinometers, piezometers, and topographic } \\
\text { monuments. }\end{array}$ & $\begin{array}{l}\text { Catalano and others } \\
\text { (2000), Picarelli and } \\
\text { Russo (2004)/ } \\
\text { Italian National } \\
\text { Dam Service }\end{array}$ \\
\hline $\begin{array}{l}\text { Italy/Tuscany/ } \\
44.08 \mathrm{~N}, 10.77 \mathrm{E}\end{array}$ & $\begin{array}{l}\text { Sperando } \\
\text { (Tistino)/ } \\
\text { Lima River }\end{array}$ & $\begin{array}{l}\text { Concrete } \\
\text { gravity/ } \\
\text { Hydroelectric }\end{array}$ & $\begin{array}{l}\text { 1929/Govern- } \\
\text { ment }\end{array}$ & $34 / 112$ & 0.4 & Landslide & $\begin{array}{l}\text { Left } \\
\text { abutment }\end{array}$ & $\begin{array}{l}\text { Lower half of left abutment consists of landslide } \\
\text { deposits. Probably part of the } 1818 \text { Lizzano land- } \\
\text { slide. Apparently stable at present. }\end{array}$ & $\begin{array}{l}\text { ANIDEL }(1952 \text {, } \\
\text { v. 5, p. 46-49)/ } \\
\text { L. Ermini (oral } \\
\text { commun., 1999) }\end{array}$ \\
\hline $\begin{array}{l}\text { Italy/Sicily/ } \\
37.70 \mathrm{~N}, 12.76 \mathrm{E}\end{array}$ & $\begin{array}{l}\text { Trinità/ } \\
\text { Delia River }\end{array}$ & $\begin{array}{l}\text { Earthfill/ } \\
\text { Irrigation, } \\
\text { water supply }\end{array}$ & $\begin{array}{l}\text { Irrigation } \\
\text { district/Not } \\
\text { known }\end{array}$ & $30 / 322$ & 18 & $\begin{array}{l}\text { Earth } \\
\text { flow- } \\
\text { earthslide }\end{array}$ & $\begin{array}{l}\text { Left } \\
\text { abutment }\end{array}$ & $\begin{array}{l}\text { Existence of earth flow-earth slide was known } \\
\text { during construction. Thus, spillway was built on } \\
\text { piles. In } 1965 \text { and 1981, landslide reactivated, } \\
\text { damaging caretaker's house, but not dam or appur- } \\
\text { tenant structures. Landslide still active. Instrumen- } \\
\text { tation is being added. }\end{array}$ & $\begin{array}{l}\text { Catalano and others } \\
(2000) / \text { Italian Na- } \\
\text { tional Dam Service }\end{array}$ \\
\hline $\begin{array}{l}\text { Italy/Veneto/ } \\
46.41 \mathrm{~N}, 12.25 \mathrm{E}\end{array}$ & $\begin{array}{l}\text { Vodo/Boite } \\
\text { River }\end{array}$ & $\begin{array}{l}\text { Concrete } \\
\text { domed-arch/ } \\
\text { Hydroelectric }\end{array}$ & $\begin{array}{l}\text { 1960/Govern- } \\
\text { ment }\end{array}$ & $42 / 74$ & 1.39 & $\begin{array}{l}\text { "Alluvial } \\
\text { land- } \\
\text { slides" }\end{array}$ & $\begin{array}{l}\text { Left } \\
\text { abutment }\end{array}$ & $\begin{array}{l}\text { Diaphragm, consisting of overlapped piles in rein- } \\
\text { forced concrete, contacts left abutment, which } \\
\text { is described as "morainic materials and alluvial } \\
\text { landslides." Bentonitic slurry aided excavation for } \\
\text { diaphragm. }\end{array}$ & $\begin{array}{l}\text { ANIDEL (1961, v. } \\
\text { 1, p. 320)/None }\end{array}$ \\
\hline $\begin{array}{l}\text { Japan/Saitama/ } \\
36 \text { N, 139E }\end{array}$ & $\begin{array}{l}\text { Futase/Ara } \\
\text { River }\end{array}$ & $\begin{array}{l}\text { Concrete arch/ } \\
\text { Multipurpose, } \\
\text { irrigation, } \\
\text { hydroelectric }\end{array}$ & $\begin{array}{l}\text { 1962/Federal } \\
\text { government }\end{array}$ & $95 / 289$ & 26.9 & Slide & $\begin{array}{l}\text { Left } \\
\text { abutment }\end{array}$ & $\begin{array}{l}\text { Slide in phyllite, sericite, and schist of the left } \\
\text { abutment occurred during construction (mid-Feb- } \\
\text { ruary 1958). Remedial measures: (1) piling, ( } 2 \text { ) } \\
\text { underground drainage, and (3) a buttress. Dam was } \\
\text { eventually completed. }\end{array}$ & $\begin{array}{l}\text { Taniguchi, 1967/ } \\
\text { None }\end{array}$ \\
\hline
\end{tabular}


Appendix table A. Dam characteristics, relation to landslides, mitigative measures, and cited references-Continued.

\begin{tabular}{|c|c|c|c|c|c|c|c|c|c|}
\hline $\begin{array}{l}\text { Country/ } \\
\text { state or } \\
\text { province/ } \\
\text { latitude, } \\
\text { longitude }\end{array}$ & $\begin{array}{l}\text { Dam/river } \\
\text { or stream }\end{array}$ & $\begin{array}{l}\text { Dam type/ } \\
\text { purpose }\end{array}$ & $\begin{array}{l}\text { Year } \\
\text { constructed/ } \\
\text { owner }\end{array}$ & $\begin{array}{l}\text { Height/ } \\
\text { length } \\
(\mathrm{m})\end{array}$ & $\begin{array}{c}\text { Storage } \\
\text { volume } \\
\left(\mathrm{Mm}^{3}\right)\end{array}$ & $\begin{array}{l}\text { Landslide } \\
\text { type }\end{array}$ & $\begin{array}{l}\text { Landslide } \\
\text { position } \\
\text { relative } \\
\text { to } \\
\text { dam }\end{array}$ & Comments & $\begin{array}{l}\text { References/ } \\
\text { sources } \\
\text { of } \\
\text { information }\end{array}$ \\
\hline $\begin{array}{l}\text { Japan/Ishikawa/ } \\
36.02 \mathrm{~N}, 136.76 \mathrm{E}\end{array}$ & $\begin{array}{l}\text { Jinnosuke \#5 } \\
\text { sabo dam } \\
\text { (new dam)/ } \\
\text { Tedori River }\end{array}$ & $\begin{array}{l}\text { Concrete grav- } \\
\text { ity/Debris- } \\
\text { flow retention }\end{array}$ & $\begin{array}{l}1925 \text { (original } \\
\text { dam)/ } \\
\text { Government }\end{array}$ & $\begin{array}{l}22.5 / \\
\sim 50\end{array}$ & $\begin{array}{c}\text { Not } \\
\text { known }\end{array}$ & $\begin{array}{l}\text { Deep- } \\
\text { seated } \\
\text { slide }\end{array}$ & $\begin{array}{l}\text { Entire } \\
\text { foundation }\end{array}$ & $\begin{array}{l}\text { Largest of more than } 50 \text { sabo dams built on pre- } \\
\text { existing slide (Jinnosuke-dani) in altered sandstone, } \\
\text { shale, and rhyolite (entire gully is moving). The } \\
\text { original Jinnosuke \#5 dam (height: } 17 \mathrm{~m} \text { ) has moved } \\
\text { about } 5 \mathrm{~m} \text { since } 1925 \text { and was recently rebuilt as } \\
\text { New Jinnosuke \#5. There are several other dams } \\
\text { in the valley that are } 10 \mathrm{~m} \text { high or higher (notable: } \\
\text { Jinnosuke \#3, 18 m, and Jinnosuke \#6, 13 m). Even } \\
\text { though these dams are slowly moving, all are suc- } \\
\text { cessfully performing their debris-retention function. }\end{array}$ & $\begin{array}{l}\text { Fukuoka and } \\
\text { Taniguchi (1961), } \\
\text { Ohta and others } \\
\text { (1996), Wang and } \\
\text { others (2003), } \\
\text { Okuno and oth- } \\
\text { ers (2004)/M. } \\
\text { Fukuoka (written } \\
\text { commun., 1999) }\end{array}$ \\
\hline $\begin{array}{l}\text { Japan/Niigata/ } \\
37.5 \mathrm{~N}, 138.9 \mathrm{E}\end{array}$ & $\begin{array}{l}\text { Kassa/ } \\
\text { Kassa River }\end{array}$ & $\begin{array}{l}\text { Rockfill/ } \\
\text { Hydroelectric }\end{array}$ & $\begin{array}{l}\text { 1978/Electric } \\
\text { power com- } \\
\text { pany }\end{array}$ & $90 / 487$ & 13.5 & $\begin{array}{l}\text { Volcanic } \\
\text { mudflow }\end{array}$ & $\begin{array}{l}\text { Left } \\
\text { abutment }\end{array}$ & $\begin{array}{l}\text { Most of left abutment consists of "low-cemented } \\
\text { volcanic mud-flow deposit." Entire foundation area } \\
\text { subjected to shallow grouting ( } 1,500 \mathrm{~m}^{3} \text { of mortar). } \\
\text { After grouting, top } 2-3 \mathrm{~m} \text { of mud flow was removed. }\end{array}$ & $\begin{array}{l}\text { Japanese National } \\
\text { Committee on } \\
\text { Large Dams } \\
\text { (1979, p. 26), } \\
\text { Mikuni (1980)/ } \\
\text { None }\end{array}$ \\
\hline $\begin{array}{l}\text { Japan/Tochigi/ } \\
36.7 \mathrm{~N}, 139.5 \mathrm{E}\end{array}$ & $\begin{array}{l}\text { Kawamata/ } \\
\text { Kinu River }\end{array}$ & $\begin{array}{l}\text { Concrete arch/ } \\
\text { Flood control, } \\
\text { hydroelectric, } \\
\text { irrigation }\end{array}$ & $\begin{array}{l}\text { 1966/Federal } \\
\text { government }\end{array}$ & $117 / 137$ & 87.6 & $\begin{array}{l}\text { Rock } \\
\text { fractures } \\
\text { and shear } \\
\text { zones }\end{array}$ & Abutment & $\begin{array}{l}\text { "....rock strata were permeated by fractures and } \\
\text { failure zones, and could not be relied upon to take } \\
\text { the stresses transmitted by the dam unless special } \\
\text { measures were adopted" (Hobst and Zajíc, 1983, p. } \\
\text { 392-394). Prestressed anchors were used to affix a } \\
\text { load-distribution wall to the rock face. }\end{array}$ & $\begin{array}{l}\text { Hobst and } \\
\text { Zajíc }(1983, \\
\text { p. 392-394)/None }\end{array}$ \\
\hline $\begin{array}{l}\text { Japan/ } \\
\text { Fukushima/ } \\
37.5 \mathrm{~N}, 140.0 \mathrm{E}\end{array}$ & $\begin{array}{l}\text { Ouchi/ } \\
\text { Ono River }\end{array}$ & $\begin{array}{l}\text { Earthfill/ } \\
\text { Hydroelectric }\end{array}$ & $\begin{array}{l}\text { 1988/Electric } \\
\text { power com- } \\
\text { pany }\end{array}$ & $102 / 340$ & 18.5 & Mud flow & $\begin{array}{l}\text { Left } \\
\text { abutment } \\
\text { and left } \\
\text { end of } \\
\text { foundation }\end{array}$ & $\begin{array}{l}\text { Pre-existing mud-flow deposit, derived from vol- } \\
\text { canic tuffs upstream, was removed at cutoff trench } \\
\text { and partially moved upstream (replaced by rockfill). } \\
\text { However, deposit was left in place beneath the } \\
\text { downstream part of the dam. }\end{array}$ & $\begin{array}{l}\text { Mikuni (1980), } \\
\text { Kawashima } \\
\text { and Kanazawa } \\
(1982), \text { Watanabe } \\
(1985) / \text { None }\end{array}$ \\
\hline $\begin{array}{l}\text { Japan/Tochigi/ } \\
36.8 \mathrm{~N}, 139.9 \mathrm{E}\end{array}$ & $\begin{array}{l}\text { Terayama/ } \\
\text { Miya River }\end{array}$ & $\begin{array}{l}\text { Rockfill/ } \\
\text { Flood control, } \\
\text { irrigation }\end{array}$ & $\begin{array}{l}\text { 1984/ Prefec- } \\
\text { ture govern- } \\
\text { ment }\end{array}$ & $62 / 260$ & 1.2 & $\begin{array}{l}\text { Rock fall } \\
\text { (talus) }\end{array}$ & $\begin{array}{l}\text { Right } \\
\text { abutment }\end{array}$ & $\begin{array}{l}\text { Surface of right abutment covered by talus. As reme- } \\
\text { dial measure, talus layer was covered by an "earth } \\
\text { blanket." Curtain grouting performed through lower } \\
\text { end of blanket. }\end{array}$ & $\begin{array}{l}\text { Takemura and } \\
\text { others }(1991) / \\
\text { None }\end{array}$ \\
\hline
\end{tabular}


Appendix table A. Dam characteristics, relation to landslides, mitigative measures, and cited references—Continued.

\begin{tabular}{|c|c|c|c|c|c|c|c|c|c|}
\hline $\begin{array}{l}\text { Country/ } \\
\text { state or } \\
\text { province/ } \\
\text { latitude, } \\
\text { longitude }\end{array}$ & $\begin{array}{l}\text { Dam/river } \\
\text { or stream }\end{array}$ & $\begin{array}{l}\text { Dam type/ } \\
\text { purpose }\end{array}$ & $\begin{array}{c}\text { Year } \\
\text { constructed/ } \\
\text { owner }\end{array}$ & $\begin{array}{l}\text { Height/ } \\
\text { length } \\
\text { (m) }\end{array}$ & $\begin{array}{l}\text { Storage } \\
\text { volume } \\
\left(\mathrm{Mm}^{3}\right)\end{array}$ & $\begin{array}{l}\text { Landslide } \\
\text { type }\end{array}$ & $\begin{array}{l}\text { Landslide } \\
\text { position } \\
\text { relative to } \\
\text { dam }\end{array}$ & Comments & $\begin{array}{l}\text { References/ } \\
\text { sources } \\
\text { of } \\
\text { information }\end{array}$ \\
\hline $\begin{array}{l}\text { Kazakhstan/ } \\
\text { None/ } \\
43.16 \mathrm{~N}, 76.90 \mathrm{E}\end{array}$ & $\begin{array}{l}\text { Debris-flow- } \\
\text { retention } \\
\text { dam/Bol- } \\
\text { shaya Alma- } \\
\text { Atinka River }\end{array}$ & $\begin{array}{l}\text { Cellular } \\
\text { reinforced } \\
\text { concrete/ } \\
\text { Debris-flow } \\
\text { retention }\end{array}$ & $\begin{array}{l}\text { 1982/ } \\
\text { Government }\end{array}$ & $40 / 422$ & 14.5 & $\begin{array}{l}\text { Debris } \\
\text { flows }\end{array}$ & Foundation & $\begin{array}{l}\text { This debris-flow-retention structure was built } \\
\text { on pre-existing debris flows with no loss of } \\
\text { function. It is meant to control debris flows that } \\
\text { often occur on the Bolshaya Alma-Atinka River } \\
\text { upstream from Almaty. }\end{array}$ & $\begin{array}{l}\text { Yesenov and } \\
\text { Degovets (1979, } \\
\text { 1982), Sheko } \\
\text { (1988), Popov } \\
\text { (1999)/None }\end{array}$ \\
\hline $\begin{array}{l}\text { Kazakhstan/ } \\
\text { None/ } \\
43.20 \mathrm{~N}, 76.99 \mathrm{E}\end{array}$ & $\begin{array}{l}\text { Medeo/ } \\
\text { Malaya } \\
\text { Alma-Atinka } \\
\text { River }\end{array}$ & $\begin{array}{l}\text { Earthfill/ } \\
\text { Debris-flow } \\
\text { retention }\end{array}$ & $\begin{array}{l}\text { First dam: } \\
\text { 1969; } \\
\text { additional } \\
\text { higher dam: } \\
\sim 1975-80 / \\
\text { Government }\end{array}$ & $150 / 530$ & $\begin{array}{c}\text { Useful } \\
\text { retention } \\
\text { capacity } \\
12.6\end{array}$ & $\begin{array}{l}\text { Debris } \\
\text { flows }\end{array}$ & Foundation & $\begin{array}{l}\text { Original 110-m-high dam was built on debris- } \\
\text { flow base as an explosives-charged "landslide" } \\
\text { dam. "Reservoir" was nearly filled by } 1973 \\
\text { debris flow. Additional height added after } 1973 \\
\text { as a conventional earthfill dam. Dam serves } \\
\text { function well; bedrock foundation is not needed. }\end{array}$ & $\begin{array}{l}\text { Yesenov and } \\
\text { Degovets (1979, } \\
\text { 1982), Popov } \\
(1999) / \text { None }\end{array}$ \\
\hline $\begin{array}{l}\text { Mexico/Durango/ } \\
36.02 \mathrm{~N}, 136.76 \mathrm{~W}\end{array}$ & $\begin{array}{l}\text { Francisco } \\
\text { Zarco (Las } \\
\text { Tórtolas)/ } \\
\text { Nazas River }\end{array}$ & $\begin{array}{l}\text { Earthfill/ } \\
\text { Irrigation, } \\
\text { flood control }\end{array}$ & $\begin{array}{l}\text { 1969/ } \\
\text { Government }\end{array}$ & $40 / 480$ & 438 & $\begin{array}{l}\text { Talus with } \\
\text { landslide } \\
\text { blocks }\end{array}$ & $\begin{array}{l}\text { Both } \\
\text { abutments }\end{array}$ & $\begin{array}{l}\text { Talus deposits, as well as limestone blocks, are } \\
\text { found on both abutments. Impervious slurry } \\
\text { trench } 3 \mathrm{~m} \text { wide and } 20 \mathrm{~m} \text { deep constructed } \\
\text { through these materials. A 3-line grout curtain } \\
\text { was placed from bottom of trench. }\end{array}$ & $\begin{array}{l}\text { Marsal and Re- } \\
\text { séndiz (1971), } \\
\text { Secretaria } \\
\text { de Recursos } \\
\text { Hidráulicos } \\
\text { (1976a, p. } \\
\text { 96-125)/None }\end{array}$ \\
\hline $\begin{array}{l}\text { Mexico/Durango/ } \\
24.61 \mathrm{~N}, 103.31 \mathrm{~W}\end{array}$ & $\begin{array}{l}\text { Los Naranjos/ } \\
\text { Santa Clara } \\
\text { River }\end{array}$ & $\begin{array}{l}\text { Earthfill/ } \\
\text { Irrigation, } \\
\text { flood control }\end{array}$ & $\begin{array}{l}\text { 1985/ } \\
\text { Government }\end{array}$ & $48 / 542$ & 26 & $\begin{array}{l}\text { Landslide } \\
\text { in pyro- } \\
\text { clastic } \\
\text { rocks }\end{array}$ & $\begin{array}{l}\text { Right } \\
\text { abutment }\end{array}$ & $\begin{array}{l}\text { Original site exploration inadequate to detect } \\
\text { pre-existing slide. Reactivation of 2-million-m } \\
\text { slide began in 1987. Immediate remediation: (1) } \\
\text { controlled release of reservoir, (2) cement-ben- } \\
\text { tonite grouting of cracks, (3) unloading of upper } \\
\text { slide, and (4) permanent monitoring. }\end{array}$ & $\begin{array}{l}\text { Ramirez } \\
\text { Reynaga (1998)/ } \\
\text { U.S. Bureau of } \\
\text { Reclamation }\end{array}$ \\
\hline
\end{tabular}


Appendix table A. Dam characteristics, relation to landslides, mitigative measures, and cited references-Continued.

\begin{tabular}{|c|c|c|c|c|c|c|c|c|c|}
\hline $\begin{array}{l}\text { Country/ } \\
\text { state } \\
\text { or province/ } \\
\text { latitude, } \\
\text { longitude } \\
\end{array}$ & $\begin{array}{l}\text { Dam/river } \\
\text { or stream }\end{array}$ & $\begin{array}{c}\text { Dam type/ } \\
\text { purpose }\end{array}$ & $\begin{array}{c}\text { Year } \\
\text { constructed/ } \\
\text { owner } \\
\end{array}$ & $\begin{array}{l}\text { Height/ } \\
\text { length } \\
\text { (m) }\end{array}$ & $\begin{array}{c}\text { Storage } \\
\text { volume } \\
\left(\mathrm{Mm}^{3}\right)\end{array}$ & $\begin{array}{c}\text { Landslide } \\
\text { type }\end{array}$ & $\begin{array}{l}\text { Landslide } \\
\text { position } \\
\text { relative } \\
\text { to } \\
\text { dam }\end{array}$ & Comments & $\begin{array}{l}\text { References/ } \\
\text { sources } \\
\text { of } \\
\text { information }\end{array}$ \\
\hline $\begin{array}{l}\text { Mexico/Jalisco/ } \\
20.91 \mathrm{~N}, 103.70 \mathrm{~W}\end{array}$ & $\begin{array}{l}\text { Santa Rosa/ } \\
\text { Santiago } \\
\text { River }\end{array}$ & $\begin{array}{l}\text { Concrete arch/ } \\
\text { Hydroelectric, } \\
\text { irrigation(?) }\end{array}$ & $\begin{array}{l}\text { 1963/ } \\
\text { Government }\end{array}$ & $114 / 150$ & 400 & $\begin{array}{l}\text { "Buried" } \\
\text { landslide }\end{array}$ & $\begin{array}{l}\text { Both } \\
\text { abutments }\end{array}$ & $\begin{array}{l}\text { Old slide in right abutment underlies volcanic } \\
\text { mud flow (lahar). Highly jointed rhyolite of } \\
\text { left abutment was covered by "large rock falls" } \\
\text { (removed?) (Castilla and Colina, 1985). During } \\
\text { 1970s, minor progressive rock-wedge move- } \\
\text { ments occurred, triggering additional rock fall. } \\
\text { In 1981, rate of movement increased. Remedial } \\
\text { measures: (1) rock anchors, (2) drains, and (3) } \\
\text { gunniting. }\end{array}$ & $\begin{array}{l}\text { Marsal and Reséndiz } \\
\text { (1971), Alberro } \\
\text { (1976), Secretaria } \\
\text { de Recursos } \\
\text { Hidráulicos (1976a, } \\
\text { p. 429-473), Castilla } \\
\text { and Colina (1985)/ } \\
\text { None }\end{array}$ \\
\hline $\begin{array}{l}\text { Mexico/ } \\
\text { Tamaulipas/ } \\
\text { 23.96N, 98.66W }\end{array}$ & $\begin{array}{l}\text { Vicente } \\
\text { Guerrero/ } \\
\text { Soto la } \\
\text { Marina River }\end{array}$ & $\begin{array}{l}\text { Rockfill/ } \\
\text { Irrigation, } \\
\text { water supply, } \\
\text { flood control }\end{array}$ & $\begin{array}{l}\text { 1971/ } \\
\text { Government }\end{array}$ & $63 / 423$ & 3,900 & Talus & $\begin{array}{l}\text { Right } \\
\text { abutment }\end{array}$ & $\begin{array}{l}\text { Talus on abutment had 6-m maximum thickness. } \\
\text { Impervious clay core and sand/gravel transition } \\
\text { zones were founded on limestone bedrock abut- } \\
\text { ment after talus was removed from under these } \\
\text { zones. Apparently, dam shell (about one half of } \\
\text { dam width) was placed on talus and weathered } \\
\text { rock. No significant seepage has been noted. }\end{array}$ & $\begin{array}{l}\text { Secretaria de } \\
\text { Recursos Hidráu- } \\
\text { licos (1976b, p. } \\
\text { 228-235)/None }\end{array}$ \\
\hline $\begin{array}{l}\text { Morocco/Fez/ } \\
33.93 \mathrm{~N}, 4.67 \mathrm{~W}\end{array}$ & $\begin{array}{l}\text { Aitt Youb/ } \\
\text { Sebou River }\end{array}$ & $\begin{array}{l}\text { Earthfill/ } \\
\text { Hydroelectric }\end{array}$ & $\begin{array}{l}\text { 1990/ } \\
\text { Government }\end{array}$ & $\begin{array}{l}\text { 66/Not } \\
\text { known }\end{array}$ & $\begin{array}{c}\text { Not } \\
\text { known }\end{array}$ & $\begin{array}{l}\text { Ancient } \\
\text { landslide } \\
\text { dam }\end{array}$ & $\begin{array}{l}\text { Entire } \\
\text { foundation } \\
\text { and both } \\
\text { abutments }\end{array}$ & $\begin{array}{l}\text { Entire valley filled with landslide. Upstream and } \\
\text { downstream cofferdams (on landslide) served } \\
\text { as buttresses. Other remedial measures: (1) re- } \\
\text { moved part of landslide, (2) added rock buttress, } \\
\text { and (3) added downstream drainage. }\end{array}$ & $\begin{array}{l}\text { Bzioui and Chraibi } \\
\text { (1991)/None }\end{array}$ \\
\hline $\begin{array}{l}\text { Morocco/ } \\
\text { Tetouan/ } \\
35.44 \mathrm{~N}, 5.40 \mathrm{~W}\end{array}$ & $\begin{array}{l}\text { Nakhla/ } \\
\text { Nakhla River }\end{array}$ & $\begin{array}{l}\text { Rockfill- } \\
\text { earthfill/ } \\
\text { Water supply }\end{array}$ & $\begin{array}{l}\text { 1961/ } \\
\text { Government }\end{array}$ & $46 / 240$ & 5.7 & $\begin{array}{l}\text { Large } \\
\text { landslide } \\
\text { in flysch }\end{array}$ & $\begin{array}{l}\text { Left } \\
\text { abutment }\end{array}$ & $\begin{array}{l}\text { Large sandstone/shale slide overlying permeable } \\
\text { alluvium was overlooked in pre-construction } \\
\text { geologic investigation. Remedial measures to } \\
\text { reduce seepage: (1) grout curtain, (2) buttresses, } \\
\text { (3) impervious diaphragm along dam axis, and } \\
\text { (4) drainage gallery. Methods were successful, } \\
\text { but extra cost was large. }\end{array}$ & $\begin{array}{l}\text { Barbier (1974), } \\
\text { Záruba (1979), } \\
\text { Haddaoui and } \\
\text { Benabbou (1991)/ } \\
\text { None }\end{array}$ \\
\hline
\end{tabular}


Appendix table A. Dam characteristics, relation to landslides, mitigative measures, and cited references-Continued.

\begin{tabular}{|c|c|c|c|c|c|c|c|c|c|}
\hline $\begin{array}{l}\text { Country/ } \\
\text { state } \\
\text { or province/ } \\
\text { latitude, } \\
\text { longitude }\end{array}$ & $\begin{array}{l}\text { Dam/river } \\
\text { or stream }\end{array}$ & $\begin{array}{c}\text { Dam type/ } \\
\text { purpose }\end{array}$ & $\begin{array}{l}\text { Year } \\
\text { constructed/ } \\
\text { owner }\end{array}$ & $\begin{array}{l}\text { Height/ } \\
\text { length } \\
(\mathrm{m})\end{array}$ & $\begin{array}{l}\text { Storage } \\
\text { volume } \\
\left(\mathrm{Mm}^{3}\right)\end{array}$ & $\begin{array}{c}\text { Landslide } \\
\text { type }\end{array}$ & $\begin{array}{l}\text { Landslide } \\
\text { position } \\
\text { relative to } \\
\text { dam }\end{array}$ & Comments & $\begin{array}{l}\text { References/ } \\
\text { sources } \\
\text { of } \\
\text { information }\end{array}$ \\
\hline $\begin{array}{l}\text { Morocco/Not } \\
\text { known/ } \\
34.97 \mathrm{~N}, 3.81 \mathrm{~W}\end{array}$ & $\begin{array}{l}\text { Saddle Dam } \\
\text { F, Mohamed } \\
\text { B. A. el Khat- } \\
\text { tabi/ Neckor } \\
\text { River }\end{array}$ & $\begin{array}{l}\text { Earthfill/ } \\
\text { Irrigation, } \\
\text { water supply }\end{array}$ & $\begin{array}{l}\text { 1981/ } \\
\text { Government }\end{array}$ & $\begin{array}{l}\sim 16 / \text { Not } \\
\text { known }\end{array}$ & 33.6 & Landslide & Foundation & $\begin{array}{l}\text { Upon attempted filling of reservoir in } 1981 \text {, } \\
\text { springs occurred downstream. Series of down- } \\
\text { stream relief wells were installed. }\end{array}$ & $\begin{array}{l}\text { Boufous and Benze- } \\
\text { kri (1985)/None }\end{array}$ \\
\hline $\begin{array}{l}\text { New Zealand/ } \\
\text { Otago/ } \\
45.19 \mathrm{~S}, 169.35 \mathrm{E}\end{array}$ & $\begin{array}{l}\text { Clyde/ } \\
\text { Clutha River }\end{array}$ & $\begin{array}{l}\text { Concrete } \\
\text { gravity/ } \\
\text { Hydroelectric, } \\
\text { irrigation }\end{array}$ & $\begin{array}{l}\text { 1989/Power } \\
\text { company }\end{array}$ & $75 / 490$ & 320 & $\begin{array}{l}\text { Dip-slope } \\
\text { rock slide } \\
\text { in schist }\end{array}$ & $\begin{array}{l}\text { Right } \\
\text { abutment }\end{array}$ & $\begin{array}{l}\text { Ancient rock slide in schist (vol. } ~ 60 \text { million } \\
\mathrm{m}^{3} \text { ) encroaches on right abutment. Lower slope } \\
\text { successfully stabilized by buttressing action of } \\
\text { dam and by berm placed along right reservoir } \\
\text { shore beginning at dam face. }\end{array}$ & $\begin{array}{l}\text { Gillon and Hancox } \\
(1991), \text { New Zealand } \\
\text { Geomechanics } \\
\text { Society (1992), } \\
\text { Brown and others } \\
\text { (1993), Macfarlane } \\
\text { and Gillon (1995), } \\
\text { Foster and others } \\
(1996,2000) / \text { None }\end{array}$ \\
\hline $\begin{array}{l}\text { New Zealand/ } \\
\text { East Coast/ } \\
37.34 \mathrm{~S}, 175.79 \mathrm{E}\end{array}$ & $\begin{array}{l}\text { Golden Cross } \\
\text { tailings dam/ } \\
\text { Tributary } \\
\text { Waitekauri } \\
\text { River }\end{array}$ & $\begin{array}{l}\text { Earthfill- } \\
\text { rockfill/ } \\
\text { Mine tailings } \\
\text { storage }\end{array}$ & $\begin{array}{l}\text { 1997/ } \\
\text { Gold mining } \\
\text { company }\end{array}$ & $40 / \sim 400$ & 5 & $\begin{array}{l}\text { Dip-slope } \\
\text { slide in } \\
\text { soft } \\
\text { volcanics }\end{array}$ & $\begin{array}{l}\text { Entire } \\
\text { foundation } \\
\text { and both } \\
\text { abutments }\end{array}$ & $\begin{array}{l}\text { Tailings dam was constructed on pre-existing } \\
90 \text {-million- } \mathrm{m}^{3} \text { slide in weak volcanic rocks. As } \\
\text { a result of filling tailings pond and removal of } \\
\text { part of toe of landslide, slide was reactivated. } \\
\text { Remedial measures considered: (1) drainage } \\
\text { and (2) massive toe buttress. Golden Cross mine } \\
\text { currently closed because of low value of gold. }\end{array}$ & $\begin{array}{l}\text { Weston and Jacobs } \\
\text { (1997)/Consultants' } \\
\text { reports }\end{array}$ \\
\hline $\begin{array}{l}\text { New Zealand/ } \\
\text { East Coast/ } \\
37.34 \mathrm{~S}, 175.79 \mathrm{E}\end{array}$ & $\begin{array}{l}\text { Union Silt } \\
\text { tailings dam/ } \\
\text { Tributary } \\
\text { Waitekauri } \\
\text { River }\end{array}$ & $\begin{array}{l}\text { Earthfill/ } \\
\text { Silt control in } \\
\text { mine area }\end{array}$ & $\begin{array}{l}\text { 1997/Gold } \\
\text { mining com- } \\
\text { pany }\end{array}$ & $13 / \sim 350$ & 0.06 & $\begin{array}{l}\text { Dip-slope } \\
\text { slide in } \\
\text { soft volca- } \\
\text { nics }\end{array}$ & $\begin{array}{l}\text { Entire } \\
\text { foundation }\end{array}$ & $\begin{array}{l}\text { Silt-retention dam was constructed on pre-exist- } \\
\text { ing 90-million- } \mathrm{m}^{3} \text { slide in weak volcanic rocks } \\
\text { (same slide as Golden Cross tailings dam). } \\
\text { Remedial measures considered: (1) drainage, }(2) \\
\text { massive toe buttress. Golden Cross mine cur- } \\
\text { rently closed because of low value of gold. }\end{array}$ & $\begin{array}{l}\text { Weston and Jacobs } \\
\text { (1997)/Consultants' } \\
\text { reports }\end{array}$ \\
\hline
\end{tabular}


Appendix table A. Dam characteristics, relation to landslides, mitigative measures, and cited references-Continued.

\begin{tabular}{|c|c|c|c|c|c|c|c|c|c|}
\hline $\begin{array}{l}\text { Country/ } \\
\text { state } \\
\text { or province/ } \\
\text { latitude, } \\
\text { longitude }\end{array}$ & $\begin{array}{l}\text { Dam/river } \\
\text { or stream }\end{array}$ & $\begin{array}{c}\text { Dam type/ } \\
\text { purpose }\end{array}$ & $\begin{array}{c}\text { Year } \\
\text { constructed/ } \\
\text { owner }\end{array}$ & $\begin{array}{l}\text { Height/ } \\
\text { length } \\
\text { (m) }\end{array}$ & $\begin{array}{c}\text { Storage } \\
\text { volume } \\
\left(\mathrm{Mm}^{3}\right)\end{array}$ & $\begin{array}{l}\text { Landslide } \\
\text { type }\end{array}$ & $\begin{array}{l}\text { Landslide } \\
\text { position } \\
\text { relative to } \\
\text { dam }\end{array}$ & Comments & $\begin{array}{l}\text { References/ } \\
\text { sources } \\
\text { of } \\
\text { information }\end{array}$ \\
\hline $\begin{array}{l}\text { Papua New } \\
\text { Guinea/Eastern } \\
\text { Highlands/ } \\
6.25 \mathrm{~S}, 145.98 \mathrm{E}\end{array}$ & $\begin{array}{l}\text { Yonki/ } \\
\text { Ramu River }\end{array}$ & $\begin{array}{l}\text { Earthfill/ } \\
\text { Hydroelectric }\end{array}$ & $\begin{array}{l}\text { 1991/ } \\
\text { Government }\end{array}$ & $60 / 680$ & 332 & $\begin{array}{l}\text { Slump } \\
\text { in stiff, } \\
\text { fissured } \\
\text { clay }\end{array}$ & $\begin{array}{l}\text { Left } \\
\text { abutment }\end{array}$ & $\begin{array}{l}\text { During construction in 1987, a significant slide } \\
\text { occurred in downstream left abutment of dam. In- } \\
\text { vestigation showed that slide was a reactivation. } \\
\text { Design of dam modified to include upstream and } \\
\text { downstream berms that act as abutments. }\end{array}$ & $\begin{array}{l}\text { Bosler and others } \\
\text { (1991)/Papua New } \\
\text { Guinea Electricity } \\
\text { Commission }\end{array}$ \\
\hline $\begin{array}{l}\text { Peru/ } \\
\text { Huancavelica/ } \\
12.7 \mathrm{~S}, 74.5 \mathrm{~W}\end{array}$ & $\begin{array}{l}\text { Tablachaca/ } \\
\text { Mantaro } \\
\text { River }\end{array}$ & $\begin{array}{l}\text { Concrete grav- } \\
\text { ity/ } \\
\text { Hydroelectric }\end{array}$ & $\begin{array}{l}\text { 1972/ } \\
\text { Government }\end{array}$ & $80 / 180$ & 16 & $\begin{array}{l}\text { Slump in } \\
\text { phyllite } \\
\text { and col- } \\
\text { luvium }\end{array}$ & $\begin{array}{l}\text { Right } \\
\text { abutment }\end{array}$ & $\begin{array}{l}\text { Part of deep-seated slump ('Derrumbe no. } \\
5 \text { ") at right abutment reactivated by reservoir. } \\
\text { Active part is only } 30-50 \mathrm{~m} \text { from right end of } \\
\text { dam. Movement very slow. From } 1982-84 \text {, the } \\
\text { following costly remedial measures were suc- } \\
\text { cessfully added: (1) 467,000- } \mathrm{m}^{3} \text { toe buttress, (2) } \\
\text { rock anchors, and (3) radial, horizontal, and adit } \\
\text { drains. In } 2003 \text {, abutment area began showing } \\
\text { new distress. }\end{array}$ & $\begin{array}{l}\text { Novosad (1979), } \\
\text { Novosad and others } \\
\text { (1979), Morales } \\
\text { Arnao and others } \\
\text { (1984), Repetto } \\
\text { (1985), Millet and } \\
\text { others (1992), de } \\
\text { la Torre and others } \\
\text { (1997), Garga and } \\
\text { de la Torre (2004) } \\
\text { /Consultants }\end{array}$ \\
\hline $\begin{array}{l}\text { Poland/ } \\
\text { Bielsko Biala/ } \\
49.65 \mathrm{~N}, 19.21 \mathrm{E}\end{array}$ & $\begin{array}{l}\text { Tresna/ } \\
\text { Sola River }\end{array}$ & $\begin{array}{l}\text { Earthfill/ } \\
\text { Flood control, } \\
\text { water supply, } \\
\text { hydroelectric, } \\
\text { recreation }\end{array}$ & $\begin{array}{l}\text { 1967/ } \\
\text { Government }\end{array}$ & $37 / 312$ & 102.7 & $\begin{array}{l}\text { Rock slide } \\
\text { in sand- } \\
\text { stone and } \\
\text { shale }\end{array}$ & $\begin{array}{l}\text { Left } \\
\text { abutment }\end{array}$ & $\begin{array}{l}\text { Large sliding wedge }\left(\sim 100,000 \mathrm{~m}^{3}\right) \text { moved along } \\
\text { slickensided surface during construction. Most } \\
\text { of wedge remains in place. Remedial measures: } \\
\text { (1) concrete retaining block and wall, (2) toe but- } \\
\text { tress, (3) prestressed anchors, and (4) drainage of } \\
\text { upper part of slide. }\end{array}$ & $\begin{array}{l}\text { Bujak and others } \\
\text { (1967), Hobst and } \\
\text { Zajíc (1983, } \\
\text { p. 405)/ None }\end{array}$ \\
\hline $\begin{array}{l}\text { Poland/ } \\
\text { Bielsko Biala/ } \\
49.6 \mathrm{~N} 18.8 \mathrm{E}\end{array}$ & $\begin{array}{l}\text { Wisla-Czarne/ } \\
\text { Vistula River }\end{array}$ & $\begin{array}{l}\text { Earthfill/ } \\
\text { Flood control, } \\
\text { water supply }\end{array}$ & $\begin{array}{l}\text { 1974/Not } \\
\text { known }\end{array}$ & $37 / 271$ & 4.5 & $\begin{array}{l}\text { Rock slide } \\
\text { in shale } \\
\text { and sand- } \\
\text { stone }\end{array}$ & $\begin{array}{l}\text { Right } \\
\text { abutment }\end{array}$ & $\begin{array}{l}\text { "At the right side abutment, the huge, pres- } \\
\text { ently not active landslide is supported by the } \\
\text { body of the dam" (Dluzewski and others, 2000). } \\
\text { Inclinometers and piezometers installed in right } \\
\text { abutment to monitor possible activity. }\end{array}$ & $\begin{array}{l}\text { Dluzewski and } \\
\text { others }(2000) / \text { None }\end{array}$ \\
\hline
\end{tabular}


Appendix table A. Dam characteristics, relation to landslides, mitigative measures, and cited references-Continued.

\begin{tabular}{|c|c|c|c|c|c|c|c|c|c|}
\hline $\begin{array}{l}\text { Country/ } \\
\text { state } \\
\text { or province/ } \\
\text { latitude, } \\
\text { longitude }\end{array}$ & $\begin{array}{l}\text { Dam/river } \\
\text { or stream }\end{array}$ & $\begin{array}{l}\text { Dam type/ } \\
\text { purpose }\end{array}$ & $\begin{array}{c}\text { Year } \\
\text { constructed/ } \\
\text { owner }\end{array}$ & $\begin{array}{l}\text { Height/ } \\
\text { length } \\
\text { (m) }\end{array}$ & $\begin{array}{c}\text { Storage } \\
\text { volume } \\
\left(\mathrm{Mm}^{3}\right)\end{array}$ & $\begin{array}{l}\text { Landslide } \\
\text { type }\end{array}$ & $\begin{array}{l}\text { Landslide } \\
\text { position } \\
\text { relative to } \\
\text { dam }\end{array}$ & Comments & $\begin{array}{l}\text { References/ } \\
\text { sources } \\
\text { of } \\
\text { information }\end{array}$ \\
\hline $\begin{array}{l}\text { Slovakia/None/ } \\
48.63 \mathrm{~N}, 17.71 \mathrm{E}\end{array}$ & $\begin{array}{l}\text { Čerenec/ } \\
\text { Holeska River }\end{array}$ & $\begin{array}{l}\text { Earthfill/ } \\
\text { Multipurpose }\end{array}$ & $\begin{array}{l}\text { 1964/Not } \\
\text { known }\end{array}$ & $10 / 280$ & 1.7 & $\begin{array}{l}\text { "Ancient" } \\
\text { landslide } \\
\text { in clay } \\
\text { and sand- } \\
\text { stone }\end{array}$ & $\begin{array}{l}\text { Right } \\
\text { abutment }\end{array}$ & $\begin{array}{l}\text { After construction, seepage occurred through } \\
\text { pervious materials in the foundation (not related } \\
\text { to landslide). Remedial measures added to dam } \\
\text { to increase stability and reduce seepage: (1) } \\
\text { earth berm on downstream side of dam and (2) } \\
\text { drainage wells. }\end{array}$ & $\begin{array}{l}\text { Lukač }(1985) / \mathrm{R} \text {. } \\
\text { Holzer }(\text { Comenius } \\
\text { University, oral com- } \\
\text { mun., 1998) }\end{array}$ \\
\hline $\begin{array}{l}\text { Slovakia/Central } \\
\text { Slovakia/ } \\
49.10 \mathrm{~N}, 19.45 \mathrm{E}\end{array}$ & $\begin{array}{l}\text { Liptovská } \\
\text { Mara/Váh } \\
\text { River }\end{array}$ & $\begin{array}{l}\text { Earthfill/ } \\
\text { Hydroelectric, } \\
\text { flood control, } \\
\text { water supply }\end{array}$ & $\begin{array}{l}\text { 1976/ } \\
\text { Government }\end{array}$ & $\begin{array}{l}53 / \\
1,250\end{array}$ & 360 & $\begin{array}{l}\text { Numer- } \\
\text { ous earth } \\
\text { flows and } \\
\text { slides }\end{array}$ & $\begin{array}{l}\text { Right } \\
\text { abutment }\end{array}$ & $\begin{array}{l}\text { Dam designed so that abutment lies between } \\
\text { two slides/flows. Largest, only } 150 \mathrm{~m} \text { upstream } \\
\text { from dam axis (but immediately adjacent to } \\
\text { edge of dam), stabilized by } 700,000-\mathrm{m}^{3} \text { sand/ } \\
\text { gravel buttress. Smaller slide separated from } \\
\text { downstream edge of dam by fill. Dam system is } \\
\text { stable. }\end{array}$ & $\begin{array}{l}\text { Nemcok (1982, } \\
\text { p. 298-302), Malgot } \\
\text { and others }(2002) / \\
\text { None }\end{array}$ \\
\hline $\begin{array}{l}\text { South Africa/ } \\
\text { Western Cape/ } \\
33.81 \mathrm{~S}, 19.08 \mathrm{E}\end{array}$ & $\begin{array}{l}\text { Wemmers- } \\
\text { hoek/ } \\
\text { Wemmers } \\
\text { River }\end{array}$ & $\begin{array}{l}\text { Rockfill/ } \\
\text { Water supply }\end{array}$ & $\begin{array}{l}\text { 1957/City } \\
\text { government }\end{array}$ & $53 / 488$ & 58.8 & Talus & $\begin{array}{l}\text { Both } \\
\text { abutments }\end{array}$ & $\begin{array}{l}\text { Layers of talus were encountered along lower } \\
\text { slopes of both abutments. During excavation for } \\
\text { core trench, talus became unstable due to water, } \\
\text { necessitating drainage ditches. Talus removed } \\
\text { for core trench. }\end{array}$ & $\begin{array}{l}\text { Brink (1981, p. 215)/ } \\
\text { None }\end{array}$ \\
\hline $\begin{array}{l}\text { Spain/Castellón/ } \\
40.2 \mathrm{~N}, 0.6 \mathrm{~W}\end{array}$ & $\begin{array}{l}\text { Arenós/ } \\
\text { Mijares River }\end{array}$ & $\begin{array}{l}\text { Rockfill with } \\
\text { clay core/ } \\
\text { Irrigation }\end{array}$ & $\begin{array}{l}\text { 1978/ } \\
\text { Government }\end{array}$ & $107 / 428$ & 137.7 & $\begin{array}{l}\text { Rock fall } \\
\text { and slides }\end{array}$ & $\begin{array}{l}\text { Both } \\
\text { abutments }\end{array}$ & $\begin{array}{l}\text { Slides and rock-fall blocks were removed for } \\
\text { support of clay core and upstream filters. In } \\
1982 \text { and 1987, large slides occurred near left } \\
\text { abutment. Slides were stabilized and anchored. } \\
\text { Constant surveillance since. }\end{array}$ & $\begin{array}{l}\text { Andreu and others } \\
\text { (1988), Comité } \\
\text { Español de Grandes } \\
\text { Presas (1993, } \\
\text { p. } 72-79) \text {, Cifres } \\
\text { (1998)/ None }\end{array}$ \\
\hline $\begin{array}{l}\text { Spain/Valencia/ } \\
39.25 \mathrm{~N}, 0.95 \mathrm{~W}\end{array}$ & $\begin{array}{l}\text { Cortes de } \\
\text { Pallás/ } \\
\text { Júcar River }\end{array}$ & $\begin{array}{l}\text { Concrete arch- } \\
\text { gravity/ } \\
\text { Hydroelectric }\end{array}$ & $\begin{array}{l}\text { 1989/ } \\
\text { Hydroelectric } \\
\text { power com- } \\
\text { pany }\end{array}$ & $112 / 312$ & 116 & $\begin{array}{l}\text { Rock } \\
\text { slide in } \\
\text { limestone } \\
\text { and marl }\end{array}$ & $\begin{array}{l}\text { Left } \\
\text { abutment }\end{array}$ & $\begin{array}{l}\text { Large rock slide (vol. } \sim 5 \text { million } \mathrm{m}^{3} \text { ) barely } \\
\text { makes contact with left end of dam. Remedia- } \\
\text { tion: } 800,000 \mathrm{~m}^{3} \text { excavated from upper part of } \\
\text { landslide and moved to lower part to form berm. } \\
\text { Apparently successful. }\end{array}$ & $\begin{array}{l}\text { Alonso and oth- } \\
\text { ers (1993), Lopez } \\
\text { Marinas and others } \\
\text { (1997)/None }\end{array}$ \\
\hline
\end{tabular}


Appendix table A. Dam characteristics, relation to landslides, mitigative measures, and cited references-Continued.

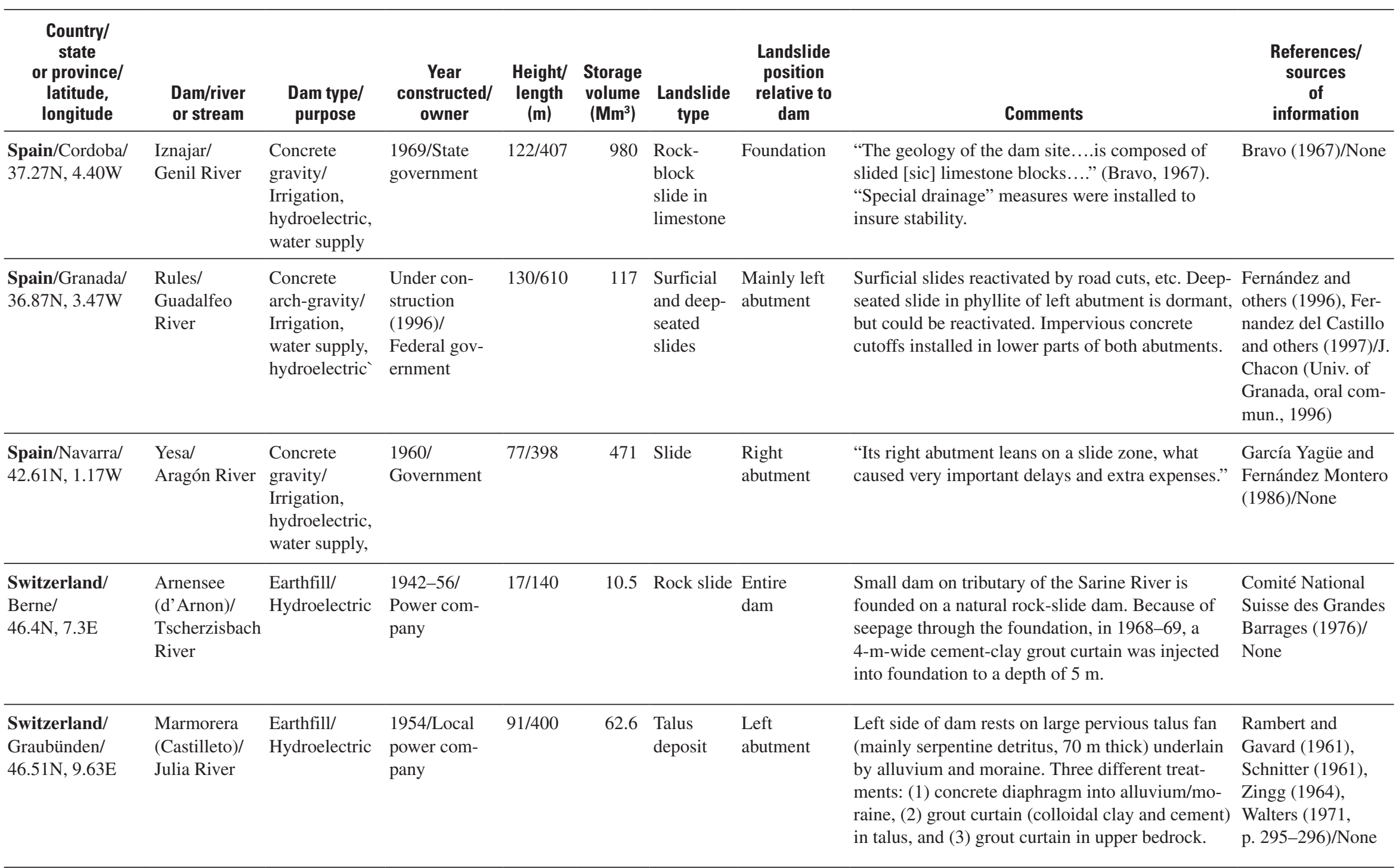


Appendix table A. Dam characteristics, relation to landslides, mitigative measures, and cited references-Continued.

\begin{tabular}{|c|c|c|c|c|c|c|c|c|c|}
\hline $\begin{array}{c}\text { Country/ } \\
\text { state } \\
\text { or province/ } \\
\text { latitude, } \\
\text { longitude }\end{array}$ & $\begin{array}{l}\text { Dam/river } \\
\text { or stream }\end{array}$ & $\begin{array}{l}\text { Dam type/ } \\
\text { purpose }\end{array}$ & $\begin{array}{c}\text { Year } \\
\text { constructed/ } \\
\text { owner }\end{array}$ & $\begin{array}{l}\text { Height/ } \\
\text { length } \\
\text { (m) }\end{array}$ & $\begin{array}{c}\text { Storage } \\
\text { volume } \\
\left(\mathrm{Mm}^{3}\right)\end{array}$ & $\begin{array}{l}\text { Landslide } \\
\text { type }\end{array}$ & $\begin{array}{l}\text { Landslide } \\
\text { position } \\
\text { relative to } \\
\text { dam }\end{array}$ & Comments & $\begin{array}{l}\text { References/ } \\
\text { sources } \\
\text { of } \\
\text { information }\end{array}$ \\
\hline $\begin{array}{l}\text { Switzerland/ } \\
\text { Glarus/ } \\
46.7 \mathrm{~N}, 9.8 \mathrm{E}\end{array}$ & $\begin{array}{l}\text { Rhodannen- } \\
\text { berg (Klöntal } \\
\text { Reservoir)/ } \\
\text { Löntsch River }\end{array}$ & $\begin{array}{l}\text { Earthfill/ } \\
\text { Hydroelectric }\end{array}$ & $\begin{array}{l}\text { 1910/Local } \\
\text { government }\end{array}$ & $27 / 217$ & 56.4 & Rock slide & $\begin{array}{l}\text { Entire } \\
\text { dam }\end{array}$ & $\begin{array}{l}\text { Small dam constructed on natural rock-slide } \\
\text { dam to gain additional power head. Considerable } \\
\text { seepage through rock-slide foundation. Jet grout- } \\
\text { ing was considered but rejected because of high } \\
\text { cost. Monitoring: (1) seepage measuring system } \\
\text { and (2) piezometers. }\end{array}$ & $\begin{array}{l}\text { Comité National } \\
\text { Suisse des Grandes } \\
\text { Barrages (1976, } \\
\text { p. 241), International } \\
\text { Commission on Large } \\
\text { Dams (1983, p. 287), } \\
\text { Venzin (1985)/None }\end{array}$ \\
\hline $\begin{array}{l}\text { Turkey/ } \\
38.52 \mathrm{~N}, 30.71 \mathrm{E}\end{array}$ & $\begin{array}{l}\text { Selevir/ } \\
\text { Kaliçay River }\end{array}$ & $\begin{array}{l}\text { Earthfill/ } \\
\text { Irrigation }\end{array}$ & $\begin{array}{l}\text { Not known/ } \\
\text { Federal gov- } \\
\text { ernment }\end{array}$ & $31 / 470$ & 62.8 & $\begin{array}{l}\text { Slide in } \\
\text { decom- } \\
\text { posed } \\
\text { schist and } \\
\text { clay }\end{array}$ & $\begin{array}{l}\text { Right } \\
\text { abutment }\end{array}$ & $\begin{array}{l}\text { Slide occurred in right abutment during construc- } \\
\text { tion. Outlet tunnel was moved away from abut- } \\
\text { ment and slide. Original outlet tunnel (affected } \\
\text { by slide) serves as a drainage outlet. Fill placed } \\
\text { at downstream portal as a buttress. Cutoff trench } \\
\text { was changed to a concrete cutoff to increase } \\
\text { stability. }\end{array}$ & $\begin{array}{l}\text { Sezginer and } \\
\text { Karacaoğlu (1961)/ } \\
\text { None }\end{array}$ \\
\hline $\begin{array}{l}\text { United Kingdom/ } \\
\text { South Yorkshire/ } \\
53.47 \mathrm{~N}, 1.60 \mathrm{~W}\end{array}$ & $\begin{array}{l}\text { Broomhead/ } \\
\text { Ewden Beck }\end{array}$ & $\begin{array}{l}\text { Earthfill/ } \\
\text { Water supply }\end{array}$ & $\begin{array}{l}1934 \text { (repair } \\
\text { of } 1929 \text { fail- } \\
\text { ure)/ } \\
\text { County water } \\
\text { authority }\end{array}$ & $31 / 302$ & 5.2 & $\begin{array}{l}\text { "Slip" in } \\
\text { "grits and } \\
\text { shales" }\end{array}$ & $\begin{array}{l}\text { Left } \\
\text { abutment }\end{array}$ & $\begin{array}{l}\text { Beginning in 1924, hillside slip (caused by } \\
\text { reservoir?) damaged valve tower and within } \\
\text { a few years threatened overflow weir. Reme- } \\
\text { dial measures: (1) surface-drain trench filled } \\
\text { with free-draining rubble, and (2) removal of } \\
\sim 300,000 \mathrm{~m}^{3} \text { of material from the slide mass. } \\
\text { In 1930, } 6 \text { million kg of cement was injected to } \\
\text { reduce leakage. }\end{array}$ & $\begin{array}{l}\text { Bromehead (1936), } \\
\text { Walters (1971, } \\
\text { p. 63-67), Interna- } \\
\text { tional Commission. } \\
\text { on Large Dams } \\
\text { (1974, p. 530), Legget } \\
\text { and Karrow (1983, } \\
\text { p. } 25-51 \text { to 25-52)/ } \\
\text { None }\end{array}$ \\
\hline $\begin{array}{l}\text { United Kingdom/ } \\
\text { Shropshire/ } \\
52.64 \mathrm{~N}, 2.53 \mathrm{~W}\end{array}$ & $\begin{array}{l}\text { Devil's } \\
\text { Dingle/ } \\
\text { Tributary } \\
\text { Severn River }\end{array}$ & $\begin{array}{l}\text { Earthfill/ } \\
\text { Fly-ash } \\
\text { disposal }\end{array}$ & $\begin{array}{l}\text { Continuing } \\
\text { construction/ } \\
\text { Electric power } \\
\text { company }\end{array}$ & $64 / 570$ & 1.68 & $\begin{array}{l}\text { "Landslip- } \\
\text { ping" in } \\
\text { mudstone }\end{array}$ & Foundation & $\begin{array}{l}\text { Information obtained from foundation boreholes } \\
\text { showed wider extent of pre-existing slip surfaces } \\
\text { than previously thought. Thus, design of down- } \\
\text { stream slope was flattened to increase stability. } \\
\text { Shallow slips in valley sides stabilized by trench } \\
\text { drains. }\end{array}$ & $\begin{array}{l}\text { Haws and } \\
\text { others }(1985) / \text { None }\end{array}$ \\
\hline
\end{tabular}


Appendix table A. Dam characteristics, relation to landslides, mitigative measures, and cited references-Continued.

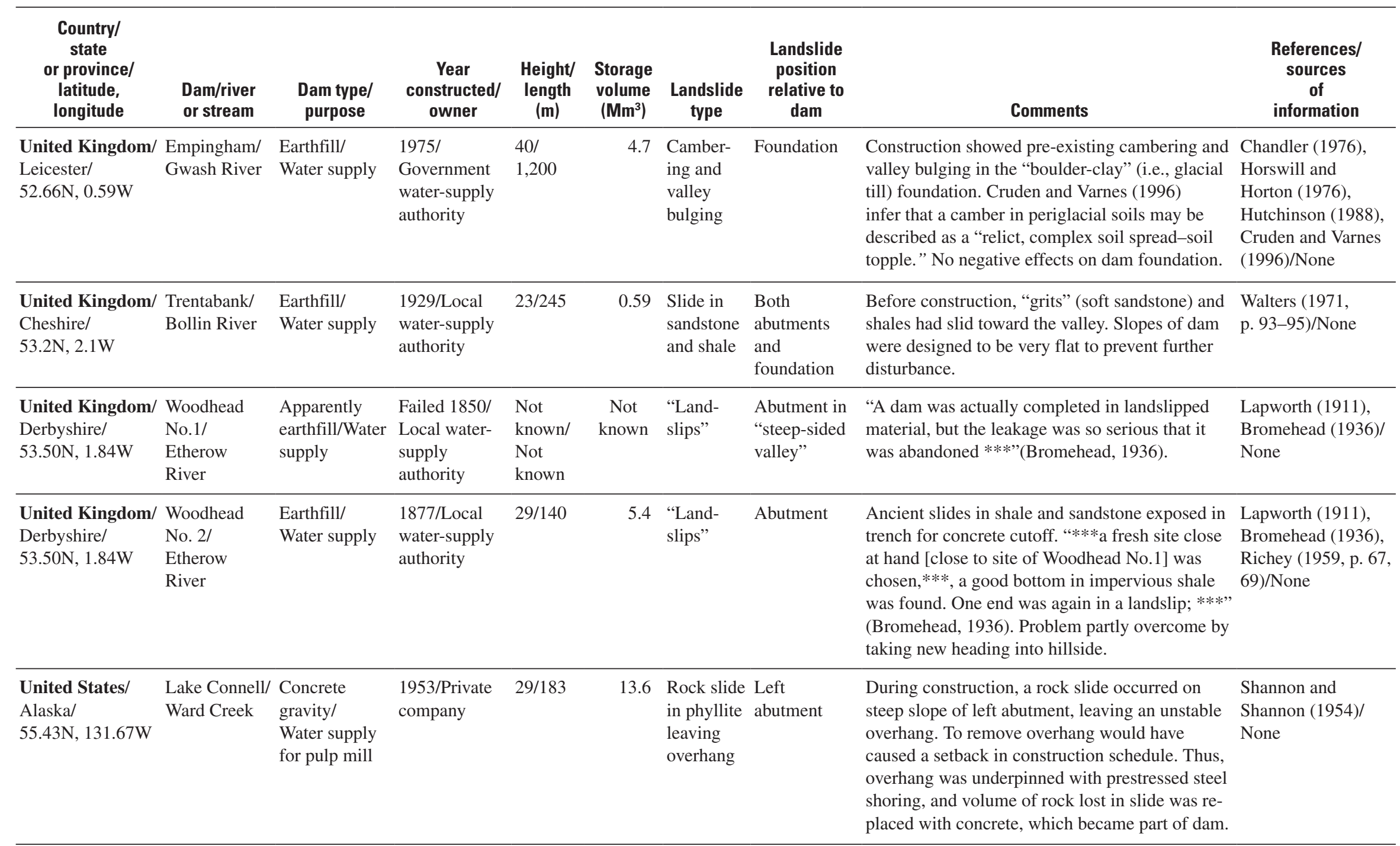


Appendix table A. Dam characteristics, relation to landslides, mitigative measures, and cited references-Continued.

\begin{tabular}{|c|c|c|c|c|c|c|c|c|c|}
\hline $\begin{array}{l}\text { Country/ } \\
\text { state } \\
\text { or province/ } \\
\text { latitude, } \\
\text { longitude }\end{array}$ & $\begin{array}{l}\text { Dam/river } \\
\text { or stream }\end{array}$ & $\begin{array}{l}\text { Dam type/ } \\
\text { purpose }\end{array}$ & $\begin{array}{c}\text { Year } \\
\text { constructed/ } \\
\text { owner }\end{array}$ & $\begin{array}{l}\text { Height/ } \\
\text { length } \\
\text { (m) }\end{array}$ & $\begin{array}{c}\text { Storage } \\
\text { volume } \\
\left(\mathrm{Mm}^{3}\right)\end{array}$ & $\begin{array}{l}\text { Landslide } \\
\text { type }\end{array}$ & $\begin{array}{l}\text { Landslide } \\
\text { position } \\
\text { relative to } \\
\text { dam }\end{array}$ & Comments & $\begin{array}{l}\text { References/ } \\
\text { sources } \\
\text { of } \\
\text { information }\end{array}$ \\
\hline $\begin{array}{l}\text { United States/ } \\
\text { Arizona/ } \\
35.09 \mathrm{~N}, 108.79 \mathrm{~W}\end{array}$ & $\begin{array}{l}\text { Black Rock } \\
\text { (Zuni)/Zuni } \\
\text { River tribu- } \\
\text { tary }\end{array}$ & $\begin{array}{l}\text { Earthfill-rock- } \\
\text { fill/ } \\
\text { Irrigation, } \\
\text { recreation }\end{array}$ & $\begin{array}{l}1908 / \\
\text { Federal gov- } \\
\text { ernment }\end{array}$ & $36 / 238$ & 3.22 & $\begin{array}{l}\text { Rock fall } \\
\text { (collapse } \\
\text { of basalt } \\
\text { abutment), } \\
\text { talus }\end{array}$ & $\begin{array}{l}\text { Both } \\
\text { abutments }\end{array}$ & $\begin{array}{l}\text { Left abutment: continuing fall of basalt blocks } \\
\text { due to piping of underlying alluvium. Right } \\
\text { abutment: talus cover. Considerable seepage } \\
\text { through both abutments. Remedial measures } \\
\text { being considered: (1) covering basalt with } \\
\text { impervious material, (2) grouting the basalt } \\
\text { beds, ( } 3 \text { ) horizontal impervious blanket, and (4) } \\
\text { vertical cutoff trench. }\end{array}$ & $\begin{array}{l}\text { Taylor and others } \\
\text { (2001), Kocahan and } \\
\text { Taylor (2002)/U.S. } \\
\text { Bureau of Reclama- } \\
\text { tion }\end{array}$ \\
\hline $\begin{array}{l}\text { United States/ } \\
\text { California/ } \\
37.13 \mathrm{~N}, 121.93 \mathrm{~W}\end{array}$ & $\begin{array}{l}\text { Austrian/ } \\
\text { Los Gatos } \\
\text { Creek }\end{array}$ & $\begin{array}{l}\text { Earthfill/ } \\
\text { Water supply }\end{array}$ & $\begin{array}{l}\text { 1950/Water- } \\
\text { supply public } \\
\text { utility }\end{array}$ & $56 / 213$ & 9.4 & $\begin{array}{l}\text { Slides in } \\
\text { sandstone } \\
\text { and silt- } \\
\text { stone }\end{array}$ & $\begin{array}{l}\text { Right and } \\
\text { possibly } \\
\text { upper-left } \\
\text { abutments }\end{array}$ & $\begin{array}{l}\text { Right abutment consists of debris from large } \\
\text { Quaternary slide. M7.1 Loma Prieta quake } \\
\text { (1989) reactivated part of slide causing major } \\
\text { damage to spillway, which was rebuilt at left end } \\
\text { of dam. Spillway relocation required removal } \\
\text { of large quantity of rocky landslide material } \\
\text { from left abutment. Grouting in } 1993 \text { in both } \\
\text { abutments. }\end{array}$ & $\begin{array}{l}\text { McLaughlin and } \\
\text { others (1991), } \\
\text { Pardini and Reichert } \\
\text { (1993)/Consultants' } \\
\text { reports; California } \\
\text { Division of Safety of } \\
\text { Dams }\end{array}$ \\
\hline $\begin{array}{l}\text { United States/ } \\
\text { California/ } \\
37.06 \mathrm{~N}, 121.08 \mathrm{~W}\end{array}$ & $\begin{array}{l}\text { B.F. Sisk (San } \\
\text { Luis)/ } \\
\text { San Luis } \\
\text { Creek }\end{array}$ & $\begin{array}{l}\text { Earthfill/ } \\
\text { Irrigation, } \\
\text { hydroelectric, } \\
\text { recreation }\end{array}$ & $\begin{array}{l}\text { 1967/Federal } \\
\text { and State gov- } \\
\text { ernments }\end{array}$ & $\begin{array}{l}116 / \\
5,669\end{array}$ & 2,540 & $\begin{array}{l}\text { Slide } \\
\text { in clay } \\
\text { slopewash } \\
\text { and dam } \\
\text { materials }\end{array}$ & $\begin{array}{l}\text { Left } \\
\text { abutment }\end{array}$ & $\begin{array}{l}\text { During drawdown in 1981, slide occurred in } \\
\text { "hard" clay slopewash of left abutment and } \\
\text { passed through the upstream face of the dam. } \\
\text { Slide moved about } 20 \mathrm{~m} \text {. Reservoir was not } \\
\text { threatened. Remedial measures: (1) construction } \\
\text { of a "keyed" berm at upstream toe of dam and } \\
\text { (2) reconstruction of face of dam. }\end{array}$ & $\begin{array}{l}\text { Von Thun (1985), } \\
\text { Subcommitee on } \\
\text { Dam Incidents and } \\
\text { Accidents (1988, } \\
\text { p. 164-165)/None }\end{array}$ \\
\hline $\begin{array}{l}\text { United States/ } \\
\text { California/ } \\
34.29 \mathrm{~N}, 118.18 \mathrm{~W}\end{array}$ & $\begin{array}{l}\text { Big Tujunga } \\
\text { No.1/Big Tu- } \\
\text { junga Creek }\end{array}$ & $\begin{array}{l}\text { Concrete arch/ } \\
\text { Water supply, } \\
\text { flood control }\end{array}$ & $\begin{array}{l}\text { 1931/County } \\
\text { government }\end{array}$ & $63 / 154$ & 87 & $\begin{array}{l}\text { Massive } \\
\text { granite } \\
\text { block } \\
\text { slide }\end{array}$ & $\begin{array}{l}\text { Right } \\
\text { abutment }\end{array}$ & $\begin{array}{l}\text { Controversy as to whether or not toe of large } \\
\text { rock-block slide upslope from right abutment } \\
\text { is at the contact with end of the dam. Morton } \\
\text { and Streitz (1969) think it is; county geologists } \\
\text { say it isn't. Discussion is academic in that right } \\
\text { abutment seems completely stable because of } \\
\text { large size of slide mass. Has been absolutely no } \\
\text { movement. }\end{array}$ & $\begin{array}{l}\text { Morton and Streitz } \\
\text { (1969)/Los Angeles } \\
\text { County reports, D. } \\
\text { M. Morton (oral } \\
\text { commun., 1997) }\end{array}$ \\
\hline
\end{tabular}


Appendix table A. Dam characteristics, relation to landslides, mitigative measures, and cited references-Continued.

\begin{tabular}{|c|c|c|c|c|c|c|c|c|c|}
\hline $\begin{array}{l}\text { Country/ } \\
\text { state } \\
\text { or province/ } \\
\text { latitude, } \\
\text { longitude }\end{array}$ & $\begin{array}{l}\text { Dam/river } \\
\text { or stream }\end{array}$ & $\begin{array}{l}\text { Dam type/ } \\
\text { purpose }\end{array}$ & $\begin{array}{c}\text { Year } \\
\text { constructed/ } \\
\text { owner }\end{array}$ & $\begin{array}{l}\text { Height/ } \\
\text { length } \\
\text { (m) }\end{array}$ & $\begin{array}{c}\text { Storage } \\
\text { volume } \\
\left(\mathrm{Mm}^{3}\right)\end{array}$ & $\begin{array}{l}\text { Landslide } \\
\text { type }\end{array}$ & $\begin{array}{l}\text { Landslide } \\
\text { position } \\
\text { relative to } \\
\text { dam }\end{array}$ & Comments & $\begin{array}{l}\text { References/ } \\
\text { sources } \\
\text { of } \\
\text { information }\end{array}$ \\
\hline $\begin{array}{l}\text { United States/ } \\
\text { California/ } \\
39.45 \mathrm{~N}, 123.39 \mathrm{~W}\end{array}$ & $\begin{array}{l}\text { Brooktrails } \\
\text { No. } 3 \text { North/ } \\
\text { Willits Creek }\end{array}$ & $\begin{array}{l}\text { Earthfill/ } \\
\text { Water supply, } \\
\text { recreation, } \\
\text { irrigation, } \\
\text { flood control }\end{array}$ & 1970/Private & $14 / 117$ & 0.6 & Earth slide & $\begin{array}{l}\text { Left } \\
\text { abutment }\end{array}$ & $\begin{array}{l}\text { There are several slides in vicinity of the dam. } \\
\text { In 1971, slide activity (reactivation?) damaged } \\
\text { retaining wall at spillway. Slope was rebuilt. } \\
\text { Remedial measures: (1) slope reshaped and (2) } \\
\text { network of deep intersecting drains added. }\end{array}$ & $\begin{array}{l}\text { Committee on Fail- } \\
\text { ures and Accidents } \\
\text { to Large Dams } \\
\text { (1976, p. 127-128)/ } \\
\text { California Division } \\
\text { of Safety of Dams; } \\
\text { consultant's reports. }\end{array}$ \\
\hline $\begin{array}{l}\text { United States/ } \\
\text { California/ } \\
37.49 \mathrm{~N}, 121.82 \mathrm{~W}\end{array}$ & $\begin{array}{l}\text { Calaveras/ } \\
\text { Calaveras } \\
\text { Creek }\end{array}$ & $\begin{array}{l}\text { Earthfill/ } \\
\text { Water supply }\end{array}$ & $\begin{array}{l}\text { 1925/City } \\
\text { government }\end{array}$ & $75 / 366$ & 163 & $\begin{array}{l}\text { Major } \\
\text { slide in } \\
\text { shale and } \\
\text { sandstone }\end{array}$ & $\begin{array}{l}\text { Right } \\
\text { abutment }\end{array}$ & $\begin{array}{l}\text { Disagreement as to existence of large slide at } \\
\text { right abutment. Nilsen (1972) mapped large } \\
\text { slide. Kintzer (1980) stated slide was small and } \\
\text { was removed during construction. Field recon- } \\
\text { naissance by author from distance noted large } \\
\text { slide still exists; however, slide is so large that it } \\
\text { poses no stability problem. }\end{array}$ & $\begin{array}{l}\text { Cotton (1972), } \\
\text { Nilsen (1972b), } \\
\text { Kintzer (1980)/Cali- } \\
\text { fornia Division of } \\
\text { Safety of Dams; } \\
\text { consultant's reports; } \\
\text { W. Cotton (oral } \\
\text { commun., 1997) }\end{array}$ \\
\hline $\begin{array}{l}\text { United States/ } \\
\text { California/ } \\
34.37 \mathrm{~N}, 119.33 \mathrm{~W}\end{array}$ & $\begin{array}{l}\text { Casitas/ } \\
\text { Coyote Creek }\end{array}$ & $\begin{array}{l}\text { Earthfill/ } \\
\text { Irrigation, } \\
\text { water supply, } \\
\text { recreation }\end{array}$ & $\begin{array}{l}1959 / \\
\text { Federal gov- } \\
\text { ernment }\end{array}$ & $102 / 607$ & 354 & $\begin{array}{l}\text { Slide in } \\
\text { sedimen- } \\
\text { tary rocks }\end{array}$ & $\begin{array}{l}\text { Lower right } \\
\text { abutment }\end{array}$ & $\begin{array}{l}\text { Landslide in shale, siltstone, and sandstone } \\
\text { largely avoided by modifying axis alignment. In } \\
\text { final design, only a small amount of landslide } \\
\text { toe underlies downstream edge of embankment. } \\
\text { No problems. }\end{array}$ & $\begin{array}{l}\text { Dibblee (1988)/U.S. } \\
\text { Bureau of Reclama- } \\
\text { tion reports }\end{array}$ \\
\hline $\begin{array}{l}\text { United States/ } \\
\text { California/ } \\
34.52 \mathrm{~N}, 118.60 \mathrm{~W}\end{array}$ & $\begin{array}{l}\text { Castaic/ } \\
\text { Castaic Creek }\end{array}$ & $\begin{array}{l}\text { Earthfill/ } \\
\text { Water supply, } \\
\text { recreation, } \\
\text { irrigation, } \\
\text { hydroelectric }\end{array}$ & $\begin{array}{l}\text { 1973/State } \\
\text { government }\end{array}$ & $\begin{array}{l}125 / \\
1,585\end{array}$ & 450 & $\begin{array}{l}\text { Block } \\
\text { glides in } \\
\text { shale }\end{array}$ & $\begin{array}{l}\text { Mainly in } \\
\text { left } \\
\text { abutment }\end{array}$ & $\begin{array}{l}\text { Old slides, as much as } 35 \mathrm{~m} \text { thick, led to shifting } \\
\text { design of dam axis to minimize effects. How- } \\
\text { ever, considerable slide activity occurred during } \\
\text { construction. Remedial measures: (1) partial } \\
\text { removal of slide material, (2) resloping of cuts, } \\
\text { (3) large toe buttresses, and (4) grouting. Studies } \\
\text { of unstable areas in left abutment conducted as } \\
\text { late as } 1995 \text {. }\end{array}$ & $\begin{array}{l}\text { Hanegan (1973), } \\
\text { Glover and others } \\
\text { (1997)/ California } \\
\text { Division of Safety } \\
\text { of Dams }\end{array}$ \\
\hline
\end{tabular}


Appendix table A. Dam characteristics, relation to landslides, mitigative measures, and cited references-Continued.

\begin{tabular}{|c|c|c|c|c|c|c|c|c|c|}
\hline $\begin{array}{l}\text { Country/ } \\
\text { state } \\
\text { or province/ } \\
\text { latitude, } \\
\text { longitude }\end{array}$ & $\begin{array}{l}\text { Dam/river } \\
\text { or stream }\end{array}$ & $\begin{array}{l}\text { Dam type/ } \\
\text { purpose }\end{array}$ & $\begin{array}{c}\text { Year } \\
\text { constructed/ } \\
\text { owner }\end{array}$ & $\begin{array}{l}\text { Height/ } \\
\text { length } \\
\text { (m) }\end{array}$ & $\begin{array}{c}\text { Storage } \\
\text { volume } \\
\left(\mathrm{Mm}^{3}\right)\end{array}$ & $\begin{array}{l}\text { Landslide } \\
\text { type }\end{array}$ & $\begin{array}{l}\text { Landslide } \\
\text { position } \\
\text { relative to } \\
\text { dam }\end{array}$ & Comments & $\begin{array}{c}\text { References/ } \\
\text { sources } \\
\text { of } \\
\text { information }\end{array}$ \\
\hline $\begin{array}{l}\text { United States/ } \\
\text { California/ } \\
37.40 \mathrm{~N}, 121.76 \mathrm{~W}\end{array}$ & $\begin{array}{l}\text { Cherry Flat/ } \\
\text { Penitencia } \\
\text { Creek }\end{array}$ & $\begin{array}{l}\text { Earthfill/ } \\
\text { Water supply }\end{array}$ & $\begin{array}{l}\text { 1936/City } \\
\text { government }\end{array}$ & $18 / 70$ & 0.86 & $\begin{array}{l}\text { Slides in } \\
\text { sedimen- } \\
\text { tary rocks }\end{array}$ & $\begin{array}{l}\text { Both abut- } \\
\text { ments }\end{array}$ & $\begin{array}{l}\text { Both abutments are in "blue clay," formed of } \\
\text { sheared and decomposed Franciscan Fm. shale } \\
\text { and sandstone. Remedial measure: left abutment } \\
\text { cutoff trench was extended to firm material. Ap- } \\
\text { parently, there are no stability problems. }\end{array}$ & $\begin{array}{l}\text { None/California } \\
\text { Division of Safety } \\
\text { of Dams }\end{array}$ \\
\hline $\begin{array}{l}\text { United States/ } \\
\text { California/ } \\
37.12 \mathrm{~N}, 121.55 \mathrm{~W}\end{array}$ & $\begin{array}{l}\text { Coyote/ } \\
\text { Coyote Creek }\end{array}$ & $\begin{array}{l}\text { Earthfill-rock- } \\
\text { fill/ Irrigation }\end{array}$ & $\begin{array}{l}\text { 1936/County } \\
\text { water-supply } \\
\text { district }\end{array}$ & $43 / 299$ & 30.2 & $\begin{array}{l}\text { Shale } \\
\text { slide }\end{array}$ & $\begin{array}{l}\text { Spillway area } \\
\text { at right abut- } \\
\text { ment }\end{array}$ & $\begin{array}{l}\text { "Slide No. } 2 \text { appears to be, in part, a reacti- } \\
\text { vated portion of an ancient landslide, most of } \\
\text { which was excavated during construction of the } \\
\text { spillway." Reactivation of this slide damaged } \\
\text { spillway. Drainage system was recommended to } \\
\text { reduce slide potential. }\end{array}$ & $\begin{array}{l}\text { None/Santa Clara } \\
\text { Water District } \\
\text { report; field visit }\end{array}$ \\
\hline $\begin{array}{l}\text { United States/ } \\
\text { California/ } \\
37.81 \mathrm{~N}, 122.00 \mathrm{~W}\end{array}$ & $\begin{array}{l}\text { Danville/ } \\
\text { Offstream }\end{array}$ & $\begin{array}{l}\text { Earthfill/Water } \\
\text { supply }\end{array}$ & $\begin{array}{l}\text { 1961/Public } \\
\text { utility district }\end{array}$ & $23 / 233$ & 0.06 & $\begin{array}{l}\text { Massive } \\
\text { landslide } \\
\text { complex } \\
\text { in sedi- } \\
\text { mentary } \\
\text { rocks }\end{array}$ & $\begin{array}{l}\text { Entire dam } \\
\text { and reservoir }\end{array}$ & $\begin{array}{l}\text { City water-supply dam and reservoir built on } \\
\text { Quaternary landslide complex (dimensions: } \sim 5 \\
\mathrm{~km} \times 1 \mathrm{~km} \text { ). Thickness of slide under reservoir is } \\
\sim 30 \mathrm{~m} \text {. No evidence of slide movement in thou- } \\
\text { sands of years, nor of lack of stability of dam. }\end{array}$ & $\begin{array}{l}\text { Nilsen }(1973) \text {, } \\
\text { Dibblee }(1980) / \\
\text { Consultants' } \\
\text { reports }\end{array}$ \\
\hline $\begin{array}{l}\text { United States/ } \\
\text { California/ } \\
36.40 \mathrm{~N}, 120.84 \mathrm{~W}\end{array}$ & $\begin{array}{l}\text { Hernandez/ } \\
\text { San Benito } \\
\text { River }\end{array}$ & $\begin{array}{l}\text { Earthfill/ } \\
\text { Recreation, } \\
\text { irrigation }\end{array}$ & $\begin{array}{l}\text { 1962/County } \\
\text { government }\end{array}$ & $38 / 290$ & 39.2 & $\begin{array}{l}\text { Slide in } \\
\text { shale and } \\
\text { serpen- } \\
\text { tinite }\end{array}$ & Left abutment & $\begin{array}{l}\text { Most landslide detritus (mainly serpentinite) was } \\
\text { removed from under left abutment core trench. } \\
\text { Dental work where necessary. Left abutment } \\
\text { shells were founded on landslide materials, but } \\
\text { loose material was removed. As of } 1981 \text { inspec- } \\
\text { tion, minor slides adjacent to left abutment were } \\
\text { active, but dam was stable. }\end{array}$ & $\begin{array}{l}\text { None/Consultants' } \\
\text { reports; California } \\
\text { Division of Safety } \\
\text { of Dams }\end{array}$ \\
\hline
\end{tabular}


Appendix table A. Dam characteristics, relation to landslides, mitigative measures, and cited references-Continued.

\begin{tabular}{|c|c|c|c|c|c|c|c|c|c|}
\hline $\begin{array}{c}\text { Country/ } \\
\text { state } \\
\text { or province/lati- } \\
\text { tude, } \\
\text { longitude }\end{array}$ & $\begin{array}{l}\text { Dam/river } \\
\text { or stream }\end{array}$ & $\begin{array}{c}\text { Dam type/ } \\
\text { purpose }\end{array}$ & $\begin{array}{c}\text { Year } \\
\text { constructed/ } \\
\text { owner }\end{array}$ & $\begin{array}{l}\text { Height/ } \\
\text { length } \\
\text { (m) }\end{array}$ & $\begin{array}{c}\text { Storage } \\
\text { volume } \\
\left(\mathrm{Mm}^{3}\right)\end{array}$ & $\begin{array}{l}\text { Landslide } \\
\text { type }\end{array}$ & $\begin{array}{l}\text { Landslide } \\
\text { position } \\
\text { relative to } \\
\text { dam }\end{array}$ & Comments & $\begin{array}{l}\text { References/ } \\
\text { sources } \\
\text { of } \\
\text { information }\end{array}$ \\
\hline $\begin{array}{l}\text { United States/ } \\
\text { California/ } \\
37.32 \mathrm{~N}, 119.32 \mathrm{~W}\end{array}$ & $\begin{array}{l}\text { Mammoth } \\
\text { Pool/ } \\
\text { San Joaquin } \\
\text { River }\end{array}$ & $\begin{array}{l}\text { Earthfill/ } \\
\text { Hydroelectric }\end{array}$ & $\begin{array}{l}\text { 1959/ } \\
\text { Private } \\
\text { electric power } \\
\text { company }\end{array}$ & $125 / 250$ & 152 & $\begin{array}{l}\text { Mainly } \\
\text { rock fall }\end{array}$ & $\begin{array}{l}\text { Entire } \\
\text { foundation }\end{array}$ & $\begin{array}{l}\text { Original valley bottom blocked by rock-fall de- } \\
\text { posits from sheeted granodiorite that impounded } \\
\text { a lake } 2.5 \mathrm{~km} \text { long. Boulders as large as } 5,000 \\
\mathrm{~m}^{3} \text {. Remaining sheets were removed or bolted } \\
\text { to canyon walls. Cutoff trench constructed } 30 \\
\mathrm{~m} \text { through detritus to bedrock. Blocks at cutoff } \\
\text { trench in valley bottom were broken up or } \\
\text { removed, but were left in place under upstream } \\
\text { outer shell. Pervious drain and filter zone pre- } \\
\text { vent migration of fine material from embank- } \\
\text { ment into voids in foundation. }\end{array}$ & $\begin{array}{l}\text { Terzaghi (1962), } \\
\text { Hamilton (1992), } \\
\text { Goodman (1993, } \\
\text { p. 242-243)/ } \\
\text { Consultants' and } \\
\text { company reports }\end{array}$ \\
\hline $\begin{array}{l}\text { United States/ } \\
\text { California/ } \\
37.52 \mathrm{~N}, 121.91 \mathrm{~W}\end{array}$ & $\begin{array}{l}\text { Mayhew } \\
\text { Reservoir/ } \\
\text { Offstream } \\
\text { (downstream } \\
\text { from Fre- } \\
\text { mont) }\end{array}$ & $\begin{array}{l}\text { Earthfill/ } \\
\text { Water supply }\end{array}$ & $\begin{array}{l}\text { 1962/ } \\
\text { Public utility } \\
\text { district }\end{array}$ & $16 / 255$ & 0.022 & $\begin{array}{l}\text { Flow part } \\
\text { of slump- } \\
\text { flow }\end{array}$ & $\begin{array}{l}\text { Entire } \\
\text { foundation } \\
\text { and reservoir }\end{array}$ & $\begin{array}{l}\text { This rectangular dam/reservoir lies on toe of the } \\
\text { Reservoir landslide, part of the Mission land- } \\
\text { slide complex. Reservoir landslide is thought to } \\
\text { be dormant. However, in } 1994 \text { reservoir-lining } \\
\text { distress resulting from active landslide move- } \\
\text { ment was observed on the eastern (upslope) part } \\
\text { of the dam. Recommended remedial measure: } \\
\text { gravel-filled drainage trenches. }\end{array}$ & $\begin{array}{l}\text { None/California } \\
\text { Division of Safety } \\
\text { of Dams; consul- } \\
\text { tants' reports }\end{array}$ \\
\hline $\begin{array}{l}\text { United States/ } \\
\text { California/ } \\
34.34 \mathrm{~N}, 117.23 \mathrm{~W}\end{array}$ & $\begin{array}{l}\text { Mojave/West } \\
\text { Fork Mojave } \\
\text { River }\end{array}$ & $\begin{array}{l}\text { Earthfill/ } \\
\text { Flood control }\end{array}$ & $\begin{array}{l}\text { 1971/ } \\
\text { Federal } \\
\text { government }\end{array}$ & $64 / 670$ & 194 & Earth slide & $\begin{array}{l}\text { Left } \\
\text { abutment }\end{array}$ & $\begin{array}{l}\text { Small slide occurred in left abutment during } \\
\text { construction. Remedial measures: (1) two berms } \\
\text { to buttress abutment and (2) redesign left end of } \\
\text { dam. }\end{array}$ & $\begin{array}{l}\text { Subcommittee on } \\
\text { Dam Incidents } \\
\text { and Accidents } \\
(1988, \text { p. 132)/ } \\
\text { None }\end{array}$ \\
\hline $\begin{array}{l}\text { United States/ } \\
\text { California/ } \\
37.05 \mathrm{~N}, 121.29 \mathrm{~W}\end{array}$ & $\begin{array}{l}\text { North Fork } \\
\text { (Pacheco } \\
\text { Lake)/ } \\
\text { Pacheco } \\
\text { Creek }\end{array}$ & $\begin{array}{l}\text { Earth fill/ } \\
\text { Water supply, } \\
\text { irrigation }\end{array}$ & $\begin{array}{l}\text { 1939/Public } \\
\text { utility district }\end{array}$ & $30 / 323$ & 11.1 & $\begin{array}{l}\text { Slide in } \\
\text { sandstone, } \\
\text { siltstone, } \\
\text { and shale }\end{array}$ & $\begin{array}{l}\text { Left } \\
\text { abutment }\end{array}$ & $\begin{array}{l}\text { Entire left abutment area exhibited landslide } \\
\text { topography. Spillway excavation led to reacti- } \\
\text { vation late in 1938. Area was drained and but- } \\
\text { tressed. Movement again in 1966-67. Spillway } \\
\text { repaired in 1967; still showed damage in } 1997 . \\
\text { Left abutment and spillway wall continue to be } \\
\text { unstable. }\end{array}$ & $\begin{array}{l}\text { Nilsen (1972a)/ } \\
\text { California Divi- } \\
\text { sion of Safety of } \\
\text { Dams; consul- } \\
\text { tants' reports }\end{array}$ \\
\hline
\end{tabular}


Appendix table A. Dam characteristics, relation to landslides, mitigative measures, and cited references-Continued.

\begin{tabular}{|c|c|c|c|c|c|c|c|c|c|}
\hline $\begin{array}{l}\text { Country/ } \\
\text { state } \\
\text { or province/ } \\
\text { latitude, } \\
\text { longitude }\end{array}$ & $\begin{array}{l}\text { Dam/river } \\
\text { or stream }\end{array}$ & $\begin{array}{c}\text { Dam type/ } \\
\text { purpose }\end{array}$ & $\begin{array}{c}\text { Year } \\
\text { constructed/ } \\
\text { owner }\end{array}$ & $\begin{array}{l}\text { Height/ } \\
\text { length } \\
\text { (m) }\end{array}$ & $\begin{array}{c}\text { Storage } \\
\text { volume } \\
\left(\mathrm{Mm}^{3}\right)\end{array}$ & $\begin{array}{c}\text { Landslide } \\
\text { type }\end{array}$ & $\begin{array}{l}\text { Landslide } \\
\text { position } \\
\text { relative to } \\
\text { dam }\end{array}$ & Comments & $\begin{array}{l}\text { References/ } \\
\text { sources } \\
\text { of } \\
\text { information }\end{array}$ \\
\hline $\begin{array}{l}\text { United States/ } \\
\text { California/ } \\
34.34 \mathrm{~N}, 118.40 \mathrm{~W}\end{array}$ & $\begin{array}{l}\text { Pacoima/ } \\
\text { Pacoima } \\
\text { Creek }\end{array}$ & $\begin{array}{l}\text { Concrete arch/ } \\
\text { Flood control }\end{array}$ & $\begin{array}{l}\text { 1929/County } \\
\text { government }\end{array}$ & $111 / 195$ & 11.4 & $\begin{array}{l}\text { Rock- } \\
\text { block } \\
\text { slide in } \\
\text { banded } \\
\text { gneiss }\end{array}$ & $\begin{array}{l}\text { Left } \\
\text { abutment }\end{array}$ & $\begin{array}{l}\text { Large rock block, serving as thrust block for left end } \\
\text { of dam, recognized as possible problem during design } \\
\text { and construction of dam. Stabilized by anchors. } \\
\text { Northridge earthquake (1994) caused slump of } 200 \\
\text { mm and horizontal displacement of } 250 \mathrm{~mm} \text {. New } \\
\text { remedial measures: (1) post-tensioned tendon anchor } \\
\text { system, (2) foundation/abutment grouting, and (3) } \\
\text { gunniting. }\end{array}$ & $\begin{array}{l}\text { Sharma and } \\
\text { others (1997)/ } \\
\text { California } \\
\text { Division of Safety } \\
\text { of Dams, Los } \\
\text { Angeles County } \\
\text { safety reports; } \\
\text { consultants' } \\
\text { reports }\end{array}$ \\
\hline $\begin{array}{l}\text { United States/ } \\
\text { California/ } \\
34.55 \mathrm{~N}, 118.51 \mathrm{~W}\end{array}$ & $\begin{array}{l}\text { St. Francis/ } \\
\text { San Francis- } \\
\text { quito Creek }\end{array}$ & $\begin{array}{l}\text { Concrete } \\
\text { gravity-arch/ } \\
\text { Water supply, } \\
\text { irrigation }\end{array}$ & $\begin{array}{l}\text { 1926/City } \\
\text { government }\end{array}$ & $62 / \sim 400$ & 47 & $\begin{array}{l}\text { Huge pre- } \\
\text { existing } \\
\text { slides in } \\
\text { schist }\end{array}$ & $\begin{array}{l}\text { Left } \\
\text { abutment }\end{array}$ & $\begin{array}{l}\text { As reservoir approached capacity during first filling } \\
\text { (1928), dam failed causing catastrophic flood that } \\
\text { drowned about } 450 \text { people. Cause of failure originally } \\
\text { thought to be fault in right abutment. However, later } \\
\text { research indicated failure occurred as reactivation of } \\
\text { series of Pleistocene slides in schist of left abutment. }\end{array}$ & $\begin{array}{l}\text { Willis (1928), } \\
\text { Outland (1977), } \\
\text { Rogers (1992, } \\
\text { 1995, 1997)/None }\end{array}$ \\
\hline $\begin{array}{l}\text { United States/ } \\
\text { California/ } \\
34.16 \mathrm{~N}, 117.78 \mathrm{~W}\end{array}$ & $\begin{array}{l}\text { San Dimas/ } \\
\text { San Dimas } \\
\text { Creek }\end{array}$ & $\begin{array}{l}\text { Concrete } \\
\text { gravity-arch/ } \\
\text { Flood control, } \\
\text { irrigation }\end{array}$ & $\begin{array}{l}\text { 1922/County } \\
\text { government }\end{array}$ & $40 / 104$ & 2.28 & $\begin{array}{l}\text { Pre-exist- } \\
\text { ing rock } \\
\text { slides }\end{array}$ & $\begin{array}{l}\text { Both } \\
\text { abutments }\end{array}$ & $\begin{array}{l}\text { Slides in heavily jointed gneisses of both abutments } \\
\text { were recognized before construction. Remedial } \\
\text { measures: (1) dam shape modified, (2) foundation } \\
\text { grouted, (3) 4,500 } \mathrm{m}^{3} \text { of rock removed from upper } \\
\text { right-abutment slopes, and (4) steel tendons and post- } \\
\text { tensioned anchors installed. Now stable. }\end{array}$ & $\begin{array}{l}\text { None/California } \\
\text { Division of Safety } \\
\text { of Dams; Los } \\
\text { Angeles County } \\
\text { Flood Control } \\
\text { District }\end{array}$ \\
\hline $\begin{array}{l}\text { United States/ } \\
\text { California/ } \\
40.82 \mathrm{~N}, 123.96 \mathrm{~W}\end{array}$ & $\begin{array}{l}\text { Sweasey/ } \\
\text { Mad River }\end{array}$ & $\begin{array}{l}\text { Composite } \\
\text { concrete arch } \\
\text { and earthfill/ } \\
\text { Water supply }\end{array}$ & $\begin{array}{l}\text { 1936/City } \\
\text { government }\end{array}$ & $23 / 61$ & 1.5 & $\begin{array}{l}\text { Slide in } \\
\text { sand- } \\
\text { stones and } \\
\text { shales }\end{array}$ & $\begin{array}{l}\text { Left } \\
\text { abutment }\end{array}$ & $\begin{array}{l}\text { During construction, slide occurred in left abutment } \\
\text { Franciscan Group sandstones and hard, clayey shales. } \\
\text { Dam was redesigned from a full masonry arch to a } \\
\text { composite section employing an arch dam across the } \\
\text { channel section, which abutted a massive concrete } \\
\text { thrust block at the left end. An earthfill section then } \\
\text { connected the thrust block with the excavated left } \\
\text { abutment. Design height was also reduced about } 20 \\
\text { m. Dam was later breached because of siltation in the } \\
\text { reservoir. }\end{array}$ & $\begin{array}{l}\text { Kiersch and James } \\
(1991) / \text { City of } \\
\text { Eureka }\end{array}$ \\
\hline
\end{tabular}


Appendix table A. Dam characteristics, relation to landslides, mitigative measures, and cited references-Continued.

\begin{tabular}{|c|c|c|c|c|c|c|c|c|c|}
\hline $\begin{array}{l}\text { Country/ } \\
\text { state or } \\
\text { province } \\
\text { /latitude, } \\
\text { longitude }\end{array}$ & $\begin{array}{l}\text { Dam/river } \\
\text { or stream }\end{array}$ & $\begin{array}{c}\text { Dam type/ } \\
\text { purpose }\end{array}$ & $\begin{array}{l}\text { Year } \\
\text { constructed/ } \\
\text { owner }\end{array}$ & $\begin{array}{l}\text { Height/ } \\
\text { length } \\
\text { (m) }\end{array}$ & $\begin{array}{l}\text { Storage } \\
\text { volume } \\
\left(\mathrm{Mm}^{3}\right)\end{array}$ & $\begin{array}{l}\text { Landslide } \\
\text { type }\end{array}$ & $\begin{array}{l}\text { Landslide } \\
\text { position } \\
\text { relative } \\
\text { to dam }\end{array}$ & Comments & $\begin{array}{l}\text { References/ } \\
\text { sources } \\
\text { of } \\
\text { information }\end{array}$ \\
\hline $\begin{array}{l}\text { United States/ } \\
\text { California/ } \\
35.17 \mathrm{~N}, 120.53 \mathrm{~W}\end{array}$ & $\begin{array}{l}\text { Terminal/ } \\
\text { Tributary } \\
\text { Arroyo } \\
\text { Grande Creek }\end{array}$ & $\begin{array}{l}\text { Earthfill/ } \\
\text { Water supply }\end{array}$ & $\begin{array}{l}\text { 1969/County } \\
\text { public utility }\end{array}$ & $16 / 168$ & 1.34 & $\begin{array}{l}\text { Bedding- } \\
\text { plane slide } \\
\text { in shale }\end{array}$ & $\begin{array}{l}\text { Left } \\
\text { abutment }\end{array}$ & $\begin{array}{l}\text { Preconstruction field studies found "old buried } \\
\text { landslide" in soft shale. Much of the slide was } \\
\text { excavated during construction. Additional stability } \\
\text { provided by addition of } 6.5 \text {-m-high upstream and } \\
\text { downstream berms. }\end{array}$ & $\begin{array}{l}\text { Cavallin (1991)/ } \\
\text { California Divi- } \\
\text { sion of Safety of } \\
\text { Dams }\end{array}$ \\
\hline $\begin{array}{l}\text { United States/ } \\
\text { California/ } \\
40.80 \mathrm{~N}, 122.76 \mathrm{~W}\end{array}$ & $\begin{array}{l}\text { Trinity/ } \\
\text { Trinity River }\end{array}$ & $\begin{array}{l}\text { Earthfill/ } \\
\text { Irrigation }\end{array}$ & $\begin{array}{l}\text { 1962/Federal } \\
\text { government }\end{array}$ & $164 / 792$ & 3,400 & $\begin{array}{l}\text { Slides in } \\
\text { sedimen- } \\
\text { tary rocks } \\
\text { and meta- } \\
\text { volcanics }\end{array}$ & $\begin{array}{l}\text { Both } \\
\text { abutments }\end{array}$ & $\begin{array}{l}\text { Slide at upstream right abutment removed during } \\
\text { construction. Large slide at downstream right abut- } \\
\text { ment was partially removed; closely monitored } \\
\text { remainder is adjacent to corner of dam, endanger- } \\
\text { ing spillway stilling basin. Toe of third potential } \\
\text { slump is buttressed by left end of dam, and poses } \\
\text { no threat. }\end{array}$ & $\begin{array}{l}\text { Walker and Harber } \\
(1961) \text {, Bock and } \\
\text { Harber (1974)/ } \\
\text { U.S. Bureau of } \\
\text { Reclamation }\end{array}$ \\
\hline $\begin{array}{l}\text { United States/ } \\
\text { California/ } \\
34.98 \mathrm{~N}, 120.32 \mathrm{~W}\end{array}$ & $\begin{array}{l}\text { Twitchell/ } \\
\text { Cuyama River }\end{array}$ & $\begin{array}{l}\text { Earthfill/ } \\
\text { Irrigation, } \\
\text { flood control }\end{array}$ & $\begin{array}{l}\text { 1958/Federal } \\
\text { government }\end{array}$ & $73 / 550$ & 491 & $\begin{array}{l}\text { Slide in } \\
\text { shale and } \\
\text { siltstone }\end{array}$ & $\begin{array}{l}\text { Left } \\
\text { abutment }\end{array}$ & $\begin{array}{l}\text { Downstream left margin of dam shell is barely in } \\
\text { contact with large landslide. No problems. Large } \\
\text { ancient slides present on reservoir shore. }\end{array}$ & Hall (1978)/None \\
\hline $\begin{array}{l}\text { United States/ } \\
\text { Colorado/ } \\
39.10 \mathrm{~N}, 107.88 \mathrm{~W}\end{array}$ & $\begin{array}{l}\text { Atkinson/ } \\
\text { Atkinson } \\
\text { Creek }\end{array}$ & $\begin{array}{l}\text { Earthfill/ } \\
\text { Irrigation, } \\
\text { hydroelectric }\end{array}$ & $\begin{array}{l}\text { 1893/Federal } \\
\text { government }\end{array}$ & $11 / 229$ & 2.5 & $\begin{array}{l}\text { Massive } \\
\text { rock glide }\end{array}$ & $\begin{array}{l}\text { Entire dam } \\
\text { and reservoir }\end{array}$ & $\begin{array}{l}\text { Entire dam and reservoir are on Grand Mesa land- } \\
\text { slide complex (mainly basalt on claystone, mantled } \\
\text { by glacial deposits). Seepage from both abutments } \\
\text { has been a continuing problem. }\end{array}$ & $\begin{array}{l}\text { Yeend (1969, } \\
\text { 1973), Colton and } \\
\text { others (1975c), } \\
\text { Baum and Odum } \\
(1996,2003) / U . S . \\
\text { Bureau of } \\
\text { Reclamation; } \\
\text { Colorado Division } \\
\text { of Water Re- } \\
\text { sources }\end{array}$ \\
\hline $\begin{array}{l}\text { United States/ } \\
\text { Colorado/ } \\
38.82 \mathrm{~N}, 107.45 \mathrm{~W}\end{array}$ & $\begin{array}{l}\text { Beaver/ } \\
\text { Minnesota } \\
\text { Creek tribu- } \\
\text { tary }\end{array}$ & $\begin{array}{l}\text { Earthfill/ } \\
\text { Irrigation, fire } \\
\text { protection, } \\
\text { recreation }\end{array}$ & 1958/Private & $34 / 296$ & 2.3 & $\begin{array}{l}\text { Shear and } \\
\text { collapse } \\
\text { of sedi- } \\
\text { mentary } \\
\text { rocks }\end{array}$ & $\begin{array}{l}\text { Both } \\
\text { abutments }\end{array}$ & $\begin{array}{l}\text { Abutments and foundation are composed of sand- } \\
\text { stone, shale, and coal. Coal has burned naturally, } \\
\text { reducing support for remaining layers, which have } \\
\text { failed locally. Abutment leakage led to } 1997 \text { instal- } \\
\text { lation of 60-mil impervious liner at both ends of } \\
\text { dam. }\end{array}$ & $\begin{array}{l}\text { None/Consultants' } \\
\text { reports; Colorado } \\
\text { Division of Water } \\
\text { Resources }\end{array}$ \\
\hline
\end{tabular}


Appendix table A. Dam characteristics, relation to landslides, mitigative measures, and cited references-Continued.

\begin{tabular}{|c|c|c|c|c|c|c|c|c|c|}
\hline $\begin{array}{l}\text { Country/ } \\
\text { state } \\
\text { or province/ } \\
\text { latitude, } \\
\text { longitude }\end{array}$ & $\begin{array}{l}\text { Dam/river } \\
\text { or stream }\end{array}$ & $\begin{array}{c}\text { Dam type/ } \\
\text { purpose }\end{array}$ & $\begin{array}{l}\text { Year } \\
\text { constructed/ } \\
\text { owner }\end{array}$ & $\begin{array}{l}\text { Height/ } \\
\text { length } \\
\text { (m) }\end{array}$ & $\begin{array}{l}\text { Storage } \\
\text { volume } \\
\left(\mathrm{Mm}^{3}\right)\end{array}$ & $\begin{array}{c}\text { Landslide } \\
\text { type }\end{array}$ & $\begin{array}{l}\text { Landslide } \\
\text { position } \\
\text { relative to } \\
\text { dam }\end{array}$ & Comments & $\begin{array}{l}\text { References/ } \\
\text { sources } \\
\text { of } \\
\text { information }\end{array}$ \\
\hline $\begin{array}{l}\text { United States/ } \\
\text { Colorado/ } \\
37.60 \mathrm{~N}, 106.67 \mathrm{~W}\end{array}$ & $\begin{array}{l}\text { Beaver Park/ } \\
\text { Beaver Creek }\end{array}$ & $\begin{array}{l}\text { Earthfill/ } \\
\text { Recreation, } \\
\text { fish, irriga- } \\
\text { tion }\end{array}$ & $\begin{array}{l}\text { 1912/State } \\
\text { government }\end{array}$ & $35 / 133$ & 7.2 & $\begin{array}{l}\text { Apparent } \\
\text { rock slide }\end{array}$ & $\begin{array}{l}\text { Right } \\
\text { abutment }\end{array}$ & $\begin{array}{l}\text { Abutment composed of badly fractured latite tuff } \\
\text { mapped as "landslide" by Hunter (1918), has been } \\
\text { stable, but has leaked considerably through the } \\
\text { years. }\end{array}$ & $\begin{array}{l}\text { Hunter (1918)/ } \\
\text { Colorado Division } \\
\text { of Water Resources }\end{array}$ \\
\hline $\begin{array}{l}\text { United States/ } \\
\text { Colorado/ } \\
39.08 \mathrm{~N}, 108.03 \mathrm{~W}\end{array}$ & $\begin{array}{l}\text { Big Beaver/ } \\
\text { Bull Creek } \\
\text { tributary }\end{array}$ & $\begin{array}{l}\text { Earthfill/ } \\
\text { Irrigation }\end{array}$ & 1936/Private & $11 / 55$ & 0.25 & $\begin{array}{l}\text { Massive } \\
\text { rock slide }\end{array}$ & $\begin{array}{l}\text { Entire dam } \\
\text { and reservoir }\end{array}$ & $\begin{array}{l}\text { Entire dam and reservoir on Grand Mesa landslide } \\
\text { complex (mainly basalt on claystone, mantled by } \\
\text { glacial deposits). Seepage through foundation in } \\
\text { 1992. Continuing seepage both north and south of } \\
\text { the dam. }\end{array}$ & $\begin{array}{l}\text { Yeend (1969, } \\
\text { 1973), Colton and } \\
\text { others (1975e), } \\
\text { Baum and Odum } \\
\text { (1996, 2003)/ } \\
\text { Colorado Division } \\
\text { of Water Resources }\end{array}$ \\
\hline $\begin{array}{l}\text { United States/ } \\
\text { Colorado/ } \\
39.54 \mathrm{~N}, 106.22 \mathrm{~W}\end{array}$ & $\begin{array}{l}\text { Black Lake } \\
\text { No.1/Black } \\
\text { Gore Creek }\end{array}$ & $\begin{array}{l}\text { Earthfill/ } \\
\text { Water } \\
\text { supply, } \\
\text { recreation }\end{array}$ & $\begin{array}{l}1939 \text { (rebuilt } \\
1995) / \text { Local } \\
\text { government }\end{array}$ & $\begin{array}{l}\sim 18 \\
\text { (after } \\
\text { rais- } \\
\text { ing)/122 }\end{array}$ & $\begin{array}{r}0.4(?) \\
(\text { con- } \\
\text { flicting } \\
\text { data) }\end{array}$ & $\begin{array}{l}\text { Debris } \\
\text { flow from } \\
\text { ancient } \\
\text { landslide }\end{array}$ & $\begin{array}{l}\text { Right } \\
\text { abutment }\end{array}$ & $\begin{array}{l}\text { Original dam raised to } \sim 18 \mathrm{~m} \text { (including cutoff) in } \\
\text { 1995. Much of original landslide removed. Cutoff } \\
\text { trench to sound bedrock. Grout curtain was placed } \\
\text { to competent bedrock in foundation and right } \\
\text { abutment. }\end{array}$ & $\begin{array}{l}\text { None/Colorado } \\
\text { Division of Water } \\
\text { Resources; consul- } \\
\text { tant's report }\end{array}$ \\
\hline $\begin{array}{l}\text { United States/ } \\
\text { Colorado/ } \\
39.10 \mathrm{~N}, 107.90 \mathrm{~W}\end{array}$ & $\begin{array}{l}\text { Bonham/Big } \\
\text { Creek }\end{array}$ & $\begin{array}{l}\text { Earthfill/ } \\
\text { Irrigation, } \\
\text { hydroelec- } \\
\text { tric }\end{array}$ & $\begin{array}{l}\text { 1900/Federal } \\
\text { government }\end{array}$ & $12 / 457$ & 2.8 & $\begin{array}{l}\text { Massive } \\
\text { rock slide }\end{array}$ & $\begin{array}{l}\text { Entire dam } \\
\text { and reservoir }\end{array}$ & $\begin{array}{l}\text { Entire dam and reservoir on Grand Mesa landslide } \\
\text { complex (mainly basalt on claystone, mantled by } \\
\text { glacial deposits). Minor foundation seepage. }\end{array}$ & $\begin{array}{l}\text { Yeend (1969, } \\
\text { 1973), Colton and } \\
\text { others (1975c), } \\
\text { Tweto and others } \\
\text { (1978), Baum } \\
\text { and Odum (1996, } \\
\text { 2003)/U.S. Bureau } \\
\text { of Reclamation }\end{array}$ \\
\hline $\begin{array}{l}\text { United States/ } \\
\text { Colorado/ } \\
40.13 \mathrm{~N}, 107.02 \mathrm{~W}\end{array}$ & $\begin{array}{l}\text { Burnt Mesa/ } \\
\text { S. branch of } \\
\text { Hunt Creek } \\
\text { tributary }\end{array}$ & $\begin{array}{l}\text { Earthfill/ } \\
\text { Irrigation }\end{array}$ & 1957/Private & $12 / 83$ & 0.3 & $\begin{array}{l}\text { Slide in } \\
\text { shale }\end{array}$ & $\begin{array}{l}\text { Right } \\
\text { abutment }\end{array}$ & $\begin{array}{l}\text { Right abutment is in shale slide. In } 1987 \text {, seepage } \\
\text { occurred in right abutment area. However, land- } \\
\text { slide generally has had no negative effect on dam. }\end{array}$ & $\begin{array}{l}\text { Colton (1975f), } \\
\text { Madole (1989)/ } \\
\text { Colorado Division } \\
\text { of Water Re- } \\
\text { sources; } \\
\text { R. Madole (U.S. } \\
\text { Geological Survey, } \\
\text { oral commun., } \\
\text { 2002) }\end{array}$ \\
\hline
\end{tabular}


Appendix table A. Dam characteristics, relation to landslides, mitigative measures, and cited references-Continued.

\begin{tabular}{|c|c|c|c|c|c|c|c|c|c|}
\hline $\begin{array}{l}\text { Country/ } \\
\text { state } \\
\text { or province/ } \\
\text { latitude, } \\
\text { longitude }\end{array}$ & $\begin{array}{l}\text { Dam/river } \\
\text { or stream }\end{array}$ & $\begin{array}{c}\text { Dam type/ } \\
\text { purpose }\end{array}$ & $\begin{array}{c}\text { Year } \\
\text { constructed/ } \\
\text { owner }\end{array}$ & $\begin{array}{l}\text { Height/ } \\
\text { length } \\
\text { (m) }\end{array}$ & $\begin{array}{c}\text { Storage } \\
\text { volume } \\
\left(\mathrm{Mm}^{3}\right)\end{array}$ & $\begin{array}{l}\text { Landslide } \\
\text { type }\end{array}$ & $\begin{array}{l}\text { Landslide } \\
\text { position } \\
\text { relative to } \\
\text { dam }\end{array}$ & Comments & $\begin{array}{l}\text { References/ } \\
\text { sources of } \\
\text { information }\end{array}$ \\
\hline $\begin{array}{l}\text { United States/ } \\
\text { Colorado/ } \\
39.05 \mathrm{~N}, 107.85 \mathrm{~W}\end{array}$ & $\begin{array}{l}\text { Cedar Mesa/ } \\
\text { Surface Creek }\end{array}$ & $\begin{array}{l}\text { Earthfill/ } \\
\text { Irrigation }\end{array}$ & 1944/Private & $14 / 381$ & 1.7 & $\begin{array}{l}\text { Massive } \\
\text { rock slide }\end{array}$ & $\begin{array}{l}\text { Entire dam } \\
\text { and reservoir }\end{array}$ & $\begin{array}{l}\text { Entire dam and reservoir on Grand Mesa } \\
\text { landslide complex (mainly basalt on claystone, } \\
\text { mantled by glacial deposits). "Blowout" (1971) } \\
\text { in foundation at left abutment corrected by vi- } \\
\text { nyl membrane; satisfactory performance since. }\end{array}$ & $\begin{array}{l}\text { Yeend }(1969,1973) \text {, } \\
\text { Colton and others } \\
(1975 c) / \text { Colorado } \\
\text { Division of Water } \\
\text { Resources; consul- } \\
\text { tant's report }\end{array}$ \\
\hline $\begin{array}{l}\text { United States/ } \\
\text { Colorado/ } \\
39.67 \mathrm{~N}, 105.70 \mathrm{~W}\end{array}$ & $\begin{array}{l}\text { Clear Lake/ } \\
\text { South Clear } \\
\text { Creek }\end{array}$ & $\begin{array}{l}\text { Rockfill/ } \\
\text { Hydro- } \\
\text { electric, } \\
\text { recreation }\end{array}$ & $\begin{array}{l}\text { 1914/Public } \\
\text { utility }\end{array}$ & $12 / 55$ & 0.6 & Rock slide & $\begin{array}{l}\text { Entire dam } \\
\text { foundation } \\
\text { and both } \\
\text { abutments }\end{array}$ & $\begin{array}{l}\text { Dam was built on landslide dam formed by rock } \\
\text { slides and talus from both valley walls. Seep- } \\
\text { age and piping occurred through left-abutment } \\
\text { talus, resulting in "sinkholes" (1997). Remedial } \\
\text { grouting in talus. }\end{array}$ & $\begin{array}{l}\text { Widmann and } \\
\text { Miersemann (2001); } \\
\text { Hammer (2002)/ } \\
\text { Colorado Division of } \\
\text { Water Resources; } \\
\text { R. Madole (U.S. } \\
\text { Geological Survey, } \\
\text { oral commun., 2002) }\end{array}$ \\
\hline $\begin{array}{l}\text { United States/ } \\
\text { Colorado/ } \\
40.17 \mathrm{~N}, 107.67 \mathrm{~W}\end{array}$ & $\begin{array}{l}\text { D.D.\&E. } \\
\text { Wise (Aldrich } \\
\text { Lake)/Hulch } \\
\text { Creek diver- } \\
\text { sion ditch }\end{array}$ & $\begin{array}{l}\text { Earthfill/ } \\
\text { Irrigation }\end{array}$ & 1946/Private & $12 / 104$ & 1.8 & $\begin{array}{l}\text { Massive } \\
\text { slide in } \\
\text { shale }\end{array}$ & $\begin{array}{l}\text { Entire dam } \\
\text { and reservoir }\end{array}$ & $\begin{array}{l}\text { D.D.\&E. Wise Dam and its reservoir, Aldrich } \\
\text { Lake, are located on the eastern edge of a } \\
\text { massive } 13-\mathrm{km}^{2} \text { landslide in Mancos Shale. } \\
\text { Landslide material has had no negative effect } \\
\text { on dam or reservoir performance. }\end{array}$ & $\begin{array}{l}\text { Colton and oth- } \\
\text { ers (1975f), Reheis } \\
\text { (1984), Madole } \\
\text { 1989)/Colorado } \\
\text { Division of Water } \\
\text { Resources; } \\
\text { R. Madole (U.S. } \\
\text { Geol. Survey, } \\
\text { oral commun., 2002) }\end{array}$ \\
\hline
\end{tabular}


Appendix table A. Dam characteristics, relation to landslides, mitigative measures, and cited references-Continued.

\begin{tabular}{|c|c|c|c|c|c|c|c|c|c|}
\hline $\begin{array}{l}\text { Country/ } \\
\text { state } \\
\text { or province/ } \\
\text { latitude, } \\
\text { longitude }\end{array}$ & $\begin{array}{l}\text { Dam/river } \\
\text { or stream }\end{array}$ & $\begin{array}{l}\text { Dam type/ } \\
\text { purpose }\end{array}$ & $\begin{array}{l}\text { Year } \\
\text { constructed/ } \\
\text { owner }\end{array}$ & $\begin{array}{l}\text { Height/ } \\
\text { length } \\
\text { (m) }\end{array}$ & $\begin{array}{c}\text { Storage } \\
\text { volume } \\
\left(\mathrm{Mm}^{3}\right)\end{array}$ & $\begin{array}{c}\text { Landslide } \\
\text { type }\end{array}$ & $\begin{array}{l}\text { Landslide } \\
\text { position } \\
\text { relative to } \\
\text { dam }\end{array}$ & Comments & $\begin{array}{l}\text { References/ } \\
\text { sources } \\
\text { of } \\
\text { information }\end{array}$ \\
\hline $\begin{array}{l}\text { United States/ } \\
\text { Colorado/ } \\
39.04 \mathrm{~N}, 107.95 \mathrm{~W}\end{array}$ & $\begin{array}{l}\text { Eggleston/ } \\
\text { Kiser Creek }\end{array}$ & $\begin{array}{l}\text { Earthfill/ } \\
\text { Irrigation }\end{array}$ & 1949/Private & $12 / 101$ & 5.0 & $\begin{array}{l}\text { Massive } \\
\text { rock slide }\end{array}$ & $\begin{array}{l}\text { Entire dam } \\
\text { and reservoir }\end{array}$ & $\begin{array}{l}\text { Entire dam and reservoir are on Grand Mesa } \\
\text { landslide complex (mainly basalt on claystone, } \\
\text { mantled by glacial deposits). Very minor seep- } \\
\text { age; no serious problems. }\end{array}$ & $\begin{array}{l}\text { Yeend (1969, } \\
\text { 1973), Colton and } \\
\text { others }(1975 \mathrm{c}), \\
\text { Baum and Odum } \\
(1996,2003) / \\
\text { Colorado Division } \\
\text { of Water Resources }\end{array}$ \\
\hline $\begin{array}{l}\text { United States/ } \\
\text { Colorado/ } \\
38.83 \mathrm{~N}, 107.96 \mathrm{~W}\end{array}$ & $\begin{array}{l}\text { Fruitgrowers/ } \\
\text { Alfalfa Run } \\
\text { Creek }\end{array}$ & $\begin{array}{l}\text { Earthfill/ } \\
\text { Irrigation, } \\
\text { recreation }\end{array}$ & $\begin{array}{l}\text { 1939/Federal } \\
\text { government }\end{array}$ & $17 / 463$ & 9.3 & $\begin{array}{l}\text { Apparent } \\
\text { slide in } \\
\text { shale }\end{array}$ & $\begin{array}{l}\text { Left } \\
\text { abutment }\end{array}$ & $\begin{array}{l}\text { Slow movement along gently dipping failure } \\
\text { surface began in late } 1990 \text { s. At present, Bureau } \\
\text { of Reclamation is trying to define and solve the } \\
\text { problem. }\end{array}$ & $\begin{array}{l}\text { None/U.S. Bureau } \\
\text { of Reclamation }\end{array}$ \\
\hline $\begin{array}{l}\text { United States/ } \\
\text { Colorado/ } \\
39.04 \mathrm{~N}, 107.68 \mathrm{~W}\end{array}$ & $\begin{array}{l}\text { Goodenough } \\
\# 2 / \text { Leroux } \\
\text { Creek tribu- } \\
\text { tary }\end{array}$ & $\begin{array}{l}\text { Earthfill/ } \\
\text { Irrigation, } \\
\text { water supply }\end{array}$ & 1928/Private & $12 / 232$ & 1.5 & $\begin{array}{l}\text { Massive } \\
\text { rock slide }\end{array}$ & $\begin{array}{l}\text { Entire dam } \\
\text { and reservoir }\end{array}$ & $\begin{array}{l}\text { Entire dam and reservoir are on Grand Mesa } \\
\text { landslide complex (mainly basalt on claystone, } \\
\text { mantled by glacial deposits). Minimal founda- } \\
\text { tion leakage at toe. }\end{array}$ & $\begin{array}{l}\text { Yeend (1969, } \\
\text { 1973), Colton and } \\
\text { others (1975c), } \\
\text { Baum and Odum } \\
(1996,2003) / \\
\text { Colorado Division } \\
\text { of Water Resources }\end{array}$ \\
\hline $\begin{array}{l}\text { United States/ } \\
\text { Colorado/ } \\
39.00 \mathrm{~N}, 108.04 \mathrm{~W}\end{array}$ & $\begin{array}{l}\text { Granby \#12/ } \\
\text { Dirty George } \\
\text { Creek tribu- } \\
\text { tary }\end{array}$ & $\begin{array}{l}\text { Earthfill/ } \\
\text { Irrigation }\end{array}$ & 1949/Private & $10 / 273$ & 1.3 & $\begin{array}{l}\text { Massive } \\
\text { rock slide }\end{array}$ & $\begin{array}{l}\text { Entire dam } \\
\text { and reservoir }\end{array}$ & $\begin{array}{l}\text { Entire dam and reservoir are on Grand Mesa } \\
\text { landslide complex (mainly basalt on claystone, } \\
\text { mantled by glacial deposits). Foundation seep- } \\
\text { age during 1970s caused small slumps in toe of } \\
\text { embankment. Minor foundation seepage still } \\
\text { occurs. }\end{array}$ & $\begin{array}{l}\text { Yeend (1969, } \\
\text { 1973), Colton and } \\
\text { others (1975e), } \\
\text { Ellis and Gabaldo } \\
\text { (1989), Baum and } \\
\text { Odum (1996, } \\
\text { 2003)/Colorado } \\
\text { Division of } \\
\text { Water Resources }\end{array}$ \\
\hline $\begin{array}{l}\text { United States/ } \\
\text { Colorado/ } \\
39.95 \mathrm{~N}, 105.36 \mathrm{~W}\end{array}$ & $\begin{array}{l}\text { Gross/South } \\
\text { Boulder } \\
\text { Creek }\end{array}$ & $\begin{array}{l}\text { Concrete } \\
\text { gravity/ } \\
\text { Water supply, } \\
\text { hydro- } \\
\text { electric, } \\
\text { recreation }\end{array}$ & $\begin{array}{l}\text { 1955/Public } \\
\text { utility }\end{array}$ & $104 / 332$ & 58.7 & $\begin{array}{l}\text { Deep- } \\
\text { seated } \\
\text { rock slide }\end{array}$ & $\begin{array}{l}\text { Both } \\
\text { abutments }\end{array}$ & $\begin{array}{l}\text { Wahlstrom (1974, p. } 74) \text { noted deep-seated } \\
\text { "gravity-slip surfaces in steep-walled canyon } \\
\text { in massive crystalline rock." No effect on dam } \\
\text { performance. Dam forms buttress against any } \\
\text { future movement. }\end{array}$ & $\begin{array}{l}\text { Wahlstrom (1974, } \\
\text { p. 74, 77-79)/None }\end{array}$ \\
\hline
\end{tabular}


Appendix table A. Dam characteristics, relation to landslides, mitigative measures, and cited references-Continued.

\begin{tabular}{|c|c|c|c|c|c|c|c|c|c|}
\hline $\begin{array}{l}\text { Country/ } \\
\text { state } \\
\text { or province/ } \\
\text { latitude, } \\
\text { longitude }\end{array}$ & $\begin{array}{l}\text { Dam/river } \\
\text { or stream }\end{array}$ & $\begin{array}{l}\text { Dam type/ } \\
\text { purpose }\end{array}$ & $\begin{array}{l}\text { Year } \\
\text { constructed/ } \\
\text { owner }\end{array}$ & $\begin{array}{l}\text { Height/ } \\
\text { length } \\
\text { (m) }\end{array}$ & $\begin{array}{c}\text { Storage } \\
\text { volume } \\
\left(\mathrm{Mm}^{3}\right)\end{array}$ & $\begin{array}{l}\text { Landslide } \\
\text { type }\end{array}$ & $\begin{array}{l}\text { Landslide } \\
\text { position } \\
\text { relative to } \\
\text { dam }\end{array}$ & Comments & $\begin{array}{l}\text { References/ } \\
\text { sources } \\
\text { of } \\
\text { information }\end{array}$ \\
\hline $\begin{array}{l}\text { United States/ } \\
\text { Colorado/ } \\
40.84 \mathrm{~N}, 106.99 \mathrm{~W}\end{array}$ & $\begin{array}{l}\text { Hahn's Peak/ } \\
\text { Willow Creek }\end{array}$ & $\begin{array}{l}\text { Earthfill/ } \\
\text { Recreation, } \\
\text { fish and wild- } \\
\text { life }\end{array}$ & $\begin{array}{l}\text { 1978/State } \\
\text { government }\end{array}$ & $12 / 82$ & 1.0 & $\begin{array}{l}\text { Slide in } \\
\text { shale }\end{array}$ & $\begin{array}{l}\text { Left } \\
\text { abutment }\end{array}$ & $\begin{array}{l}\text { Slide in shale of Morrison Formation serves as } \\
\text { left abutment. No problems have developed. }\end{array}$ & $\begin{array}{l}\text { Madole (1991b)/ } \\
\text { Colorado Division of } \\
\text { Water Resources; } \\
\text { R. Madole (U.S. } \\
\text { Geol. Survey, oral } \\
\text { commun., 2002) }\end{array}$ \\
\hline $\begin{array}{l}\text { United States/ } \\
\text { Colorado/ } \\
39.00 \mathrm{~N}, 108.11 \mathrm{~W}\end{array}$ & $\begin{array}{l}\text { Hogchute/ } \\
\text { Kannah Creek }\end{array}$ & $\begin{array}{l}\text { Earthfill/Water } \\
\text { supply }\end{array}$ & $\begin{array}{l}\text { 1947/City } \\
\text { government }\end{array}$ & $17 / 189$ & 1.1 & Rock slide & $\begin{array}{l}\text { Entire dam } \\
\text { and reservoir } \\
\text { on landslide }\end{array}$ & $\begin{array}{l}\text { Entire dam and reservoir on part of Grand Mesa } \\
\text { landslide complex (mainly basalt on claystone, } \\
\text { mantled by glacial deposits). Right abutment is } \\
\text { on basalt talus. No negative effects on dam. }\end{array}$ & $\begin{array}{l}\text { Yeend }(1969,1973) \text {, } \\
\text { Colton and others } \\
\text { (1975d), Ellis and } \\
\text { Gabaldo (1989)/ } \\
\text { Colorado Division of } \\
\text { Water Resources }\end{array}$ \\
\hline $\begin{array}{l}\text { United States/ } \\
\text { Colorado/ } \\
40.12 \mathrm{~N}, 107.02 \mathrm{~W}\end{array}$ & $\begin{array}{l}\text { Joe Wright/ } \\
\text { Joe Wright } \\
\text { Creek }\end{array}$ & $\begin{array}{l}\text { Earthfill/ } \\
\text { Water supply, } \\
\text { irrigation, } \\
\text { recreation }\end{array}$ & $\begin{array}{l}\text { 1979/City } \\
\text { government }\end{array}$ & $45 / 701$ & 11.5 & $\begin{array}{l}\text { Huge rock } \\
\text { slide }\end{array}$ & $\begin{array}{l}\text { Right } \\
\text { abutment and } \\
\text { right end of } \\
\text { dam }\end{array}$ & $\begin{array}{l}\text { Entire right valley wall is huge Quaternary } \\
\text { landslide mass (volcanics over sedimentary } \\
\text { rocks), probably formed upon glacier retreat. No } \\
\text { problems. }\end{array}$ & $\begin{array}{l}\text { Colton and others } \\
(1975 b) / \text { None }\end{array}$ \\
\hline $\begin{array}{l}\text { United States/ } \\
\text { Colorado/ } \\
40.06 \mathrm{~N}, 106.45 \mathrm{~W}\end{array}$ & $\begin{array}{l}\text { Jones \#2/ } \\
\text { Sheep Creek } \\
\text { tributary }\end{array}$ & $\begin{array}{l}\text { Earthfill/ } \\
\text { Water supply, } \\
\text { irrigation }\end{array}$ & 1887/Private & $12 / 99$ & 0.7 & $\begin{array}{l}\text { Massive } \\
\text { block } \\
\text { glide }\end{array}$ & $\begin{array}{l}\text { Entire } \\
\text { dam and } \\
\text { reservoir }\end{array}$ & $\begin{array}{l}\text { Entire dam and reservoir lie on } 13-\mathrm{km}^{2} \text { glide } \\
\text { block in Niobrara and Dakota Formations shales } \\
\text { and sandstones. Abutments are in fractured } \\
\text { shales, resulting in seepage from toe drains. } \\
\text { Reservoir serves as water supply for City of } \\
\text { Kremmling. }\end{array}$ & $\begin{array}{l}\text { Barclay (1968, p. } \\
\text { 157), Izett and Bar- } \\
\text { clay (1973), Colton } \\
\text { and others (1975f), } \\
\text { Madole (1991a)/ } \\
\text { Colorado Division of } \\
\text { Water Resources; } \\
\text { R. Madole (U.S. } \\
\text { Geological Survey, } \\
\text { oral commun., 2002) }\end{array}$ \\
\hline
\end{tabular}


Appendix table A. Dam characteristics, relation to landslides, mitigative measures, and cited references-Continued.

\begin{tabular}{|c|c|c|c|c|c|c|c|c|c|}
\hline $\begin{array}{l}\text { Country/ } \\
\text { state } \\
\text { or province/ } \\
\text { latitude, } \\
\text { longitude }\end{array}$ & $\begin{array}{l}\text { Dam/river } \\
\text { or stream }\end{array}$ & $\begin{array}{c}\text { Dam type/ } \\
\text { purpose }\end{array}$ & $\begin{array}{l}\text { Year } \\
\text { constructed/ } \\
\text { owner }\end{array}$ & $\begin{array}{l}\text { Height/ } \\
\text { length } \\
\text { (m) }\end{array}$ & $\begin{array}{c}\text { Storage } \\
\text { volume } \\
\left(\mathrm{Mm}^{3}\right)\end{array}$ & $\begin{array}{c}\text { Landslide } \\
\text { type }\end{array}$ & $\begin{array}{l}\text { Landslide } \\
\text { position } \\
\text { relative to } \\
\text { dam }\end{array}$ & Comments & $\begin{array}{l}\text { References/ } \\
\text { sources } \\
\text { of } \\
\text { information }\end{array}$ \\
\hline $\begin{array}{l}\text { United States/ } \\
\text { Colorado/ } \\
39.06 \mathrm{~N}, 107.84 \mathrm{~W}\end{array}$ & $\begin{array}{l}\text { Kehmeier/ } \\
\text { Surface Creek } \\
\text { tributary }\end{array}$ & $\begin{array}{l}\text { Earthfill/ } \\
\text { Irrigation }\end{array}$ & 1949/Private & $10 / 172$ & 0.5 & $\begin{array}{l}\text { Massive } \\
\text { rock slide }\end{array}$ & $\begin{array}{l}\text { Entire dam } \\
\text { and reservoir }\end{array}$ & $\begin{array}{l}\text { Entire dam and reservoir on Grand Mesa landslide } \\
\text { complex (mainly basalt on claystone, mantled } \\
\text { by glacial deposits). Minor seepage through both } \\
\text { abutments. }\end{array}$ & $\begin{array}{l}\text { Yeend }(1969,1973) \text {, } \\
\text { Colton and others } \\
(1975 \mathrm{c}), \text { Tweto } \\
\text { and others (1978)/ } \\
\text { Colorado Division } \\
\text { of Water Resources }\end{array}$ \\
\hline $\begin{array}{l}\text { United States/ } \\
\text { Colorado/ } \\
\text { 39.03N, 107.96W }\end{array}$ & $\begin{array}{l}\text { Kennicott } \\
\text { Slough/Kiser } \\
\text { Creek tribu- } \\
\text { tary }\end{array}$ & $\begin{array}{l}\text { Earthfill/ } \\
\text { Irrigation }\end{array}$ & 1946/Private & $12 / 380$ & 1.5 & $\begin{array}{l}\text { Massive } \\
\text { rock slide }\end{array}$ & $\begin{array}{l}\text { Entire dam } \\
\text { and reservoir }\end{array}$ & $\begin{array}{l}\text { Entire dam and reservoir on Grand Mesa landslide } \\
\text { complex (mainly basalt on claystone, mantled } \\
\text { by glacial deposits). Minor seepage through left } \\
\text { abutment; performance generally good. }\end{array}$ & $\begin{array}{l}\text { Yeend }(1969,1973) ; \\
\text { Colton and others } \\
(1975 \mathrm{c}), \text { Tweto and } \\
\text { others }(1978), \text { Baum } \\
\text { and Odum }(1996, \\
\text { 2003)/Colorado } \\
\text { Division of Water } \\
\text { Resources }\end{array}$ \\
\hline $\begin{array}{l}\text { United States/ } \\
\text { Colorado/ } \\
39.02 \mathrm{~N}, 107.95 \mathrm{~W}\end{array}$ & $\begin{array}{l}\text { Kiser Slough/ } \\
\text { Kiser Creek }\end{array}$ & $\begin{array}{l}\text { Earthfill/ } \\
\text { Irrigation, } \\
\text { recreation }\end{array}$ & 1950/Private & $12 / 320$ & 0.9 & $\begin{array}{l}\text { Massive } \\
\text { rock slide }\end{array}$ & $\begin{array}{l}\text { Entire dam } \\
\text { and reservoir }\end{array}$ & $\begin{array}{l}\text { Entire dam and reservoir on Grand Mesa landslide } \\
\text { complex (mainly basalt on claystone, mantled by } \\
\text { glacial deposits). Foundation leakage; drain- } \\
\text { age trenches added as remedial measure have } \\
\text { improved situation. }\end{array}$ & $\begin{array}{l}\text { Yeend }(1969,1973), \\
\text { Colton and others } \\
(1975 \mathrm{c}), \text { Tweto and } \\
\text { others }(1978), \text { Baum } \\
\text { and Odum (1996, } \\
\text { 2003)/Colorado } \\
\text { Division of Water } \\
\text { Resources }\end{array}$ \\
\hline $\begin{array}{l}\text { United States/ } \\
\text { Colorado/ } \\
39.04 \mathrm{~N}, 107.88 \mathrm{~W}\end{array}$ & $\begin{array}{l}\text { Knox/ } \\
\text { Surface Creek } \\
\text { tributary }\end{array}$ & $\begin{array}{l}\text { Earthfill/ } \\
\text { Irrigation }\end{array}$ & 1954/Private & $12 / 156$ & 0.5 & $\begin{array}{l}\text { Massive } \\
\text { rock slide }\end{array}$ & $\begin{array}{l}\text { Entire dam } \\
\text { and reservoir }\end{array}$ & $\begin{array}{l}\text { Entire dam and reservoir on Grand Mesa landslide } \\
\text { complex (mainly basalt on claystone, mantled } \\
\text { by glacial deposits). Minor seepage from both } \\
\text { abutments. }\end{array}$ & $\begin{array}{l}\text { Yeend }(1969,1973), \\
\text { Colton and others } \\
(1975 \text { c), Tweto and } \\
\text { others }(1978), \text { Baum } \\
\text { and Odum (1996, } \\
\text { 2003)/Colorado } \\
\text { Division of Water } \\
\text { Resources }\end{array}$ \\
\hline
\end{tabular}


Appendix table A. Dam characteristics, relation to landslides, mitigative measures, and cited references-Continued.

\begin{tabular}{|c|c|c|c|c|c|c|c|c|c|}
\hline $\begin{array}{l}\text { Country/ } \\
\text { state } \\
\text { or province/ } \\
\text { latitude, } \\
\text { longitude }\end{array}$ & $\begin{array}{l}\text { Dam/river } \\
\text { or stream }\end{array}$ & $\begin{array}{l}\text { Dam type/ } \\
\text { purpose }\end{array}$ & $\begin{array}{l}\text { Year } \\
\text { constructed/ } \\
\text { owner }\end{array}$ & $\begin{array}{l}\text { Height/ } \\
\text { length } \\
\text { (m) }\end{array}$ & $\begin{array}{l}\text { Storage } \\
\text { volume } \\
\left(\mathrm{Mm}^{3}\right)\end{array}$ & $\begin{array}{c}\text { Landslide } \\
\text { type }\end{array}$ & $\begin{array}{l}\text { Landslide } \\
\text { position } \\
\text { relative to } \\
\text { dam }\end{array}$ & Comments & $\begin{array}{l}\text { References/ } \\
\text { sources } \\
\text { of } \\
\text { information }\end{array}$ \\
\hline $\begin{array}{l}\text { United States/ } \\
\text { Colorado/ } \\
40.97 \mathrm{~N}, 107.33 \mathrm{~W}\end{array}$ & $\begin{array}{l}\text { Lower } \\
\text { Cogdill/ } \\
\text { Government } \\
\text { Corral Creek }\end{array}$ & $\begin{array}{l}\text { Earthfill/ } \\
\text { Water sup- } \\
\text { ply, fish and } \\
\text { wildlife, fire } \\
\text { protection }\end{array}$ & 1956/Private & $12 / 146$ & 0.4 & $\begin{array}{l}\text { Massive } \\
\text { slide in } \\
\text { shale and } \\
\text { sandstone }\end{array}$ & $\begin{array}{l}\text { Entire dam } \\
\text { and reservoir }\end{array}$ & $\begin{array}{l}\text { Entire dam and reservoir lie in large }\left(18 \mathrm{~km}^{2}\right) \\
\text { landslide area overlying Lewis Shale and Mesaverde } \\
\text { Group (sandstone and shale). Landslide deposits have } \\
\text { had no negative effect on dam/reservoir performance. }\end{array}$ & $\begin{array}{l}\text { Colton and others } \\
(1975 \text { f), Madole } \\
\text { (1982)/Colorado } \\
\text { Division of Water } \\
\text { Resources; } \\
\text { R. Madole (U.S. } \\
\text { Geological Survey, } \\
\text { oral commun., } \\
\text { 2002) }\end{array}$ \\
\hline $\begin{array}{l}\text { United States/ } \\
\text { Colorado/ } \\
40.30 \mathrm{~N}, 106.29 \mathrm{~W}\end{array}$ & $\begin{array}{l}\text { Matheson/ } \\
\text { Troublesome } \\
\text { Creek }\end{array}$ & $\begin{array}{l}\text { Earthfill/ } \\
\text { Irrigation }\end{array}$ & 1951/Private & $18 / 59$ & 2.2 & $\begin{array}{l}\text { Massive } \\
\text { slide in } \\
\text { Tertiary } \\
\text { volcanics }\end{array}$ & $\begin{array}{l}\text { Left abutment } \\
\text { and possibly } \\
\text { foundation }\end{array}$ & $\begin{array}{l}\text { Dam was built on NE edge of large landslide area in } \\
\text { Tertiary volcanics overlying Morrison Fm. sand- } \\
\text { stones and shales. Seepage in right abutment area } \\
\text { through "shattered lava." Clay blanket installed to } \\
\text { prevent seepage, apparently with little success. }\end{array}$ & $\begin{array}{l}\text { Madole (1991a)/ } \\
\text { Colorado Division } \\
\text { of Water } \\
\text { Resources; } \\
\text { R. Madole (U.S. } \\
\text { Geological Survey, } \\
\text { oral commun., } \\
\text { 2002) }\end{array}$ \\
\hline $\begin{array}{l}\text { United States/ } \\
\text { Colorado/ } \\
40.14 \mathrm{~N}, 106.47 \mathrm{~W}\end{array}$ & $\begin{array}{l}\text { McElroy/ } \\
\text { Pass Creek }\end{array}$ & $\begin{array}{l}\text { Earthfill/ } \\
\text { Irrigation }\end{array}$ & 1931/Private & $15 / 76$ & 0.5 & Earth flow & $\begin{array}{l}\text { Right } \\
\text { abutment }\end{array}$ & $\begin{array}{l}\text { Earth flow from Dakota Fm. shales originally } \\
\text { dammed Pass Creek. Serves as right abutment and } \\
\text { part of foundation. Generally very little seepage; } \\
\text { minor seepage at right groin in } 1975 .\end{array}$ & $\begin{array}{l}\text { Izett and Barclay } \\
\text { (1973), Colton and } \\
\text { others (1975f), } \\
\text { Madole (1991a)/ } \\
\text { Colorado Division } \\
\text { of Water } \\
\text { Resources; } \\
\text { R. Madole (U.S. } \\
\text { Geological Survey, } \\
\text { oral commun., } \\
\text { 2002) }\end{array}$ \\
\hline $\begin{array}{l}\text { United States/ } \\
\text { Colorado/ } \\
39.21 \mathrm{~N}, 107.75 \mathrm{~W}\end{array}$ & $\begin{array}{l}\text { McKelvie \#1/ } \\
\text { Plateau Creek } \\
\text { tributary }\end{array}$ & $\begin{array}{l}\text { Earthfill/ } \\
\text { Irrigation }\end{array}$ & 1943/Private & $11 / 137$ & 0.5 & $\begin{array}{l}\text { "Old } \\
\text { landslide" }\end{array}$ & Entire dam & $\begin{array}{l}\text { Entire dam is in area mapped by Soule (1988) as "old } \\
\text { landslide." Minimal foundation seepage (slightly } \\
\text { boggy downstream; no flowing water). Dam perfor- } \\
\text { mance good. }\end{array}$ & $\begin{array}{l}\text { Soule }(1988) / \\
\text { Colorado Division } \\
\text { of Water Resources }\end{array}$ \\
\hline
\end{tabular}


Appendix table A. Dam characteristics, relation to landslides, mitigative measures, and cited references-Continued.

\begin{tabular}{|c|c|c|c|c|c|c|c|c|c|}
\hline $\begin{array}{l}\text { Country/ } \\
\text { state } \\
\text { or province/ } \\
\text { latitude, } \\
\text { longitude }\end{array}$ & $\begin{array}{l}\text { Dam/river } \\
\text { or stream }\end{array}$ & $\begin{array}{c}\text { Dam type/ } \\
\text { purpose }\end{array}$ & $\begin{array}{l}\text { Year } \\
\text { constructed/ } \\
\text { owner }\end{array}$ & $\begin{array}{l}\text { Height/ } \\
\text { length } \\
\text { (m) }\end{array}$ & $\begin{array}{l}\text { Storage } \\
\text { volume } \\
\left(\mathrm{Mm}^{3}\right)\end{array}$ & $\begin{array}{l}\text { Landslide } \\
\text { type }\end{array}$ & $\begin{array}{l}\text { Landslide } \\
\text { position } \\
\text { relative to } \\
\text { dam }\end{array}$ & Comments & $\begin{array}{l}\text { References/ } \\
\text { sources } \\
\text { of } \\
\text { information }\end{array}$ \\
\hline $\begin{array}{l}\text { United States/ } \\
\text { Colorado/ } \\
39.04 \mathrm{~N}, 107.93 \mathrm{~W}\end{array}$ & $\begin{array}{l}\text { McKoon/ } \\
\text { Young's } \\
\text { Creek }\end{array}$ & $\begin{array}{l}\text { Earthfill/ } \\
\text { Irrigation }\end{array}$ & 1948/Private & $10 / 84$ & 0.3 & $\begin{array}{l}\text { Massive } \\
\text { rock slide }\end{array}$ & $\begin{array}{l}\text { Entire } \\
\text { dam and } \\
\text { reservoir }\end{array}$ & $\begin{array}{l}\text { Entire dam and reservoir are on Grand Mesa } \\
\text { landslide complex (mainly basalt on claystone, } \\
\text { mantled by glacial deposits). No negative effects } \\
\text { on dam. }\end{array}$ & $\begin{array}{l}\text { Yeend }(1969,1973), \\
\text { Colton and others } \\
(1975 \text { c), Tweto and } \\
\text { others }(1978), \text { Baum } \\
\text { and Odum (1996, } \\
\text { 2003)/Colorado } \\
\text { Division of Water } \\
\text { Resources }\end{array}$ \\
\hline $\begin{array}{l}\text { United States/ } \\
\text { Colorado/ } \\
40.18 \mathrm{~N}, 106.57 \mathrm{~W}\end{array}$ & $\begin{array}{l}\text { McMahon \#2/ } \\
\text { Red Dirt } \\
\text { Creek }\end{array}$ & $\begin{array}{l}\text { Earthfill/ } \\
\text { Irrigation }\end{array}$ & 1945/Private & $15 / 301$ & 6.5 & $\begin{array}{l}\text { Slump- } \\
\text { earth flow }\end{array}$ & $\begin{array}{l}\text { Left } \\
\text { abutment }\end{array}$ & $\begin{array}{l}\text { Left abutment is slump-earth flow in Morrison } \\
\text { Fm. shale and sandstone. Landslide apparently } \\
\text { has had no negative effect on dam performance. }\end{array}$ & $\begin{array}{l}\text { Madole (1991a)/ } \\
\text { Colorado Division of } \\
\text { Water Resources; } \\
\text { R. Madole (U.S. } \\
\text { Geological Survey, } \\
\text { oral commun., 2002) }\end{array}$ \\
\hline $\begin{array}{l}\text { United States/ } \\
\text { Colorado/ } \\
40.27 \mathrm{~N}, 106.56 \mathrm{~W}\end{array}$ & $\begin{array}{l}\text { Milk Creek/ } \\
\text { Milk Creek }\end{array}$ & $\begin{array}{l}\text { Earthfill/ } \\
\text { Irrigation }\end{array}$ & 1925/Private & $11 / 43$ & 0.2 & $\begin{array}{l}\text { Massive } \\
\text { slide in } \\
\text { shale and } \\
\text { sandstone }\end{array}$ & $\begin{array}{l}\text { Entire } \\
\text { dam and } \\
\text { reservoir }\end{array}$ & $\begin{array}{l}\text { Entire dam and reservoir lie in large landslide } \\
\text { area in Benton Shale and Dakota Sandstone. } \\
\text { Landslide material has had no negative effects on } \\
\text { dam performance. }\end{array}$ & $\begin{array}{l}\text { Colton and others } \\
\text { (1975f), Madole } \\
\text { (1991a)/Colorado } \\
\text { Division of Water } \\
\text { Resources; R. Madole } \\
\text { (U.S. Geoogical } \\
\text { Survey, oral com- } \\
\text { mun., 2002) }\end{array}$ \\
\hline $\begin{array}{l}\text { United States/ } \\
\text { Colorado/ } \\
38.88 \mathrm{~N}, 107.47 \mathrm{~W}\end{array}$ & $\begin{array}{l}\text { Monument/ } \\
\text { Minnesota } \\
\text { Creek tribu- } \\
\text { tary }\end{array}$ & $\begin{array}{l}\text { Earthfill/ } \\
\text { Irrigation }\end{array}$ & 1889/Private & $23 / 129$ & 0.8 & Rock slide & $\begin{array}{l}\text { Left } \\
\text { abutment }\end{array}$ & $\begin{array}{l}\text { Slide mass, which extends vertically } 120 \mathrm{~m} \\
\text { above left end of dam and } 450 \mathrm{~m} \text { laterally, con- } \\
\text { sists mainly of sandstone cobbles and boulders } \\
\text { in clay matrix. Instrumented since } 1992 \text { to } \\
\text { record dam movement; however, there has been } \\
\text { no distress. Apparently no significant remedial } \\
\text { measures have yet been needed. }\end{array}$ & $\begin{array}{l}\text { Colton and others } \\
(1975 \mathrm{~g}), \text { Norfleet } \\
\text { and Marvin }(1995) / \\
\text { Colorado Division of } \\
\text { Water Resources }\end{array}$ \\
\hline
\end{tabular}


Appendix table A. Dam characteristics, relation to landslides, mitigative measures, and cited references-Continued.

\begin{tabular}{|c|c|c|c|c|c|c|c|c|c|}
\hline $\begin{array}{l}\text { Country/ } \\
\text { state } \\
\text { or province/ } \\
\text { latitude, } \\
\text { longitude }\end{array}$ & $\begin{array}{l}\text { Dam/river } \\
\text { or stream }\end{array}$ & $\begin{array}{c}\text { Dam type/ } \\
\text { purpose }\end{array}$ & $\begin{array}{c}\text { Year } \\
\text { constructed/ } \\
\text { owner }\end{array}$ & $\begin{array}{l}\text { Height/ } \\
\text { length } \\
\text { (m) }\end{array}$ & $\begin{array}{c}\text { Storage } \\
\text { volume } \\
\left(\mathrm{Mm}^{3}\right)\end{array}$ & $\begin{array}{c}\text { Landslide } \\
\text { type }\end{array}$ & $\begin{array}{l}\text { Landslide } \\
\text { position } \\
\text { relative to } \\
\text { dam }\end{array}$ & Comments & $\begin{array}{c}\text { References/ } \\
\text { sources } \\
\text { of } \\
\text { information }\end{array}$ \\
\hline $\begin{array}{l}\text { United States/ } \\
\text { Colorado/ } \\
39.11 \mathrm{~N}, 107.75 \mathrm{~W}\end{array}$ & $\begin{array}{l}\text { Monument } \\
\# 1 / \text { Monument } \\
\text { Creek }\end{array}$ & $\begin{array}{l}\text { Earthfill/ } \\
\text { Irrigation }\end{array}$ & 1960/Private & $11 / 152$ & 1.1 & $\begin{array}{l}\text { Massive } \\
\text { rock slide }\end{array}$ & $\begin{array}{l}\text { Entire } \\
\text { dam and } \\
\text { reservoir }\end{array}$ & $\begin{array}{l}\text { Entire dam and reservoir on Grand Mesa landslide } \\
\text { complex (mainly basalt on claystone, mantled by } \\
\text { glacial deposits). Some seepage from left abut- } \\
\text { ment. }\end{array}$ & $\begin{array}{l}\text { Yeend }(1969,1973) \\
\text { Colton and others } \\
(1975 c) / \text { Colorado } \\
\text { Division of Water } \\
\text { Resources }\end{array}$ \\
\hline $\begin{array}{l}\text { United States/ } \\
\text { Colorado/ } \\
37.39 \mathrm{~N}, 105.39 \mathrm{~W}\end{array}$ & $\begin{array}{l}\text { Mountain } \\
\text { Home/ } \\
\text { Trinchera } \\
\text { Creek }\end{array}$ & $\begin{array}{l}\text { Earthfill/ } \\
\text { Irrigation, } \\
\text { fisheries }\end{array}$ & 1906/Private & $47 / 145$ & 32.0 & $\begin{array}{l}\text { Rock- } \\
\text { block } \\
\text { slide }\end{array}$ & $\begin{array}{l}\text { Left } \\
\text { abutment }\end{array}$ & $\begin{array}{l}\text { Slide in basalt underlain by siltstone and sand- } \\
\text { stone. No movement since construction. Because } \\
\text { overflow spillway crosses slide block, possible in- } \\
\text { stability was conjectured. However, } 1993 \text { analysis } \\
\text { indicated no stability problem. }\end{array}$ & $\begin{array}{l}\text { None/Colorado } \\
\text { Division of Water } \\
\text { Resources; consul- } \\
\text { tants' reports }\end{array}$ \\
\hline $\begin{array}{l}\text { United States/ } \\
\text { Colorado/ } \\
40.55 \mathrm{~N}, 106.02 \mathrm{~W}\end{array}$ & $\begin{array}{l}\text { North Michi- } \\
\text { gan Creek/ } \\
\text { Michigan } \\
\text { River }\end{array}$ & $\begin{array}{l}\text { Earthfill/ } \\
\text { Recreation, } \\
\text { fish and } \\
\text { wildlife }\end{array}$ & $\begin{array}{l}\text { 1963/State } \\
\text { government }\end{array}$ & $23 / 142$ & 3.6 & Earth flow & $\begin{array}{l}\text { Left (and } \\
\text { possibly } \\
\text { right) } \\
\text { abutment }\end{array}$ & $\begin{array}{l}\text { Left abutment (and possibly right abutment) is on } \\
\text { landslide masked by glacial deposits. Except for } \\
\text { minor right-abutment seepage, landslide has had } \\
\text { no negative effect on dam. }\end{array}$ & $\begin{array}{l}\text { Madole (1991b)/ } \\
\text { Colorado Division } \\
\text { of Water Resources; } \\
\text { R. Madole (U.S. } \\
\text { Geological Survey, } \\
\text { oral commun., 2002) }\end{array}$ \\
\hline $\begin{array}{l}\text { United States/ } \\
\text { Colorado/ } \\
39.08 \mathrm{~N}, 107.65 \mathrm{~W}\end{array}$ & $\begin{array}{l}\text { Overland \#1/ } \\
\text { Cow Creek } \\
\text { (Muddy } \\
\text { Creek tribu- } \\
\text { tary) }\end{array}$ & $\begin{array}{l}\text { Earthfill/ } \\
\text { Irrigation }\end{array}$ & $\begin{array}{l}\text { Originally in } \\
\text { early } 1900 \text { s; } \\
\text { rebuilt } 1987 / \\
\text { Private }\end{array}$ & $26 / 975$ & 10.1 & Rock slide & Entire dam & $\begin{array}{l}\text { Entire dam and reservoir on huge rock slide. Be- } \\
\text { fore 1987, toe-buttress stability problems possibly } \\
\text { due to landslide material. In 1987, toe-buttress } \\
\text { drains installed and material added to toe buttress. }\end{array}$ & $\begin{array}{l}\text { Yeend }(1969,1973) \text {, } \\
\text { Colton and others } \\
(1975 \mathrm{c}) / \text { Colorado } \\
\text { Division of Water } \\
\text { Resources }\end{array}$ \\
\hline $\begin{array}{l}\text { United States/ } \\
\text { Colorado/ } \\
39.05 \mathrm{~N}, 107.88 \mathrm{~W}\end{array}$ & $\begin{array}{l}\text { Park/Surface } \\
\text { Creek }\end{array}$ & $\begin{array}{l}\text { Earthfill/ } \\
\text { Irrigation }\end{array}$ & 1940/Private & $14 / 229$ & 5.6 & $\begin{array}{l}\text { Massive } \\
\text { rock slide }\end{array}$ & $\begin{array}{l}\text { Entire } \\
\text { dam and } \\
\text { reservoir }\end{array}$ & $\begin{array}{l}\text { Entire dam and reservoir are on Grand Mesa } \\
\text { landslide complex (mainly basalt on claystone, } \\
\text { mantled by glacial deposits). Slide material is } \\
\text { fragmental basalt and fairly permeable. Thus, } \\
\text { there have been seepage problems ( } 75-115 \\
\text { l/min) through base of left abutment). Bentonite } \\
\text { added to abutment in } 1997 \text { to slow seepage. }\end{array}$ & $\begin{array}{l}\text { Yeend }(1969,1973), \\
\text { Colton and others } \\
(1975 \text { c), Tweto and } \\
\text { others }(1978), \text { Baum } \\
\text { and Odum (1996, } \\
\text { 2003)/Colorado } \\
\text { Division of Water } \\
\text { Resources }\end{array}$ \\
\hline
\end{tabular}


Appendix table A. Dam characteristics, relation to landslides, mitigative measures, and cited references—Continued.

\begin{tabular}{|c|c|c|c|c|c|c|c|c|c|}
\hline $\begin{array}{l}\text { Country/ } \\
\text { state } \\
\text { or province/ } \\
\text { latitude, } \\
\text { longitude }\end{array}$ & $\begin{array}{l}\text { Dam/river } \\
\text { or stream }\end{array}$ & $\begin{array}{l}\text { Dam type/ } \\
\text { purpose }\end{array}$ & $\begin{array}{l}\text { Year } \\
\text { constructed/ } \\
\text { owner }\end{array}$ & $\begin{array}{l}\text { Height/ } \\
\text { length } \\
\text { (m) }\end{array}$ & $\begin{array}{c}\text { Storage } \\
\text { volume } \\
\left(\mathrm{Mm}^{3}\right)\end{array}$ & $\begin{array}{l}\text { Landslide } \\
\text { type }\end{array}$ & $\begin{array}{l}\text { Landslide } \\
\text { position } \\
\text { relative to } \\
\text { dam }\end{array}$ & Comments & $\begin{array}{l}\text { References/ } \\
\text { sources } \\
\text { of } \\
\text { information }\end{array}$ \\
\hline $\begin{array}{l}\text { United States/ } \\
\text { Colorado/ } \\
40.27 \mathrm{~N}, 106.41 \mathrm{~W}\end{array}$ & $\begin{array}{l}\text { Parsons/ } \\
\text { Carter Creek }\end{array}$ & $\begin{array}{l}\text { Earthfill/ } \\
\text { Irrigation, } \\
\text { stock }\end{array}$ & 1952/Private & $12 / 84$ & 0.2 & $\begin{array}{l}\text { Slide in } \\
\text { Pierre } \\
\text { Shale }\end{array}$ & $\begin{array}{l}\text { Left } \\
\text { abutment } \\
\text { and spillway }\end{array}$ & $\begin{array}{l}\text { Left abutment and original spillway in toe of } \\
\text { pre-existing Pierre Shale slide. There was dif- } \\
\text { ficulty with the spillway; so it was moved from } \\
\text { the slide. Some seepage still flows from slide. }\end{array}$ & $\begin{array}{l}\text { Colton and others } \\
\text { (1975f), Madole } \\
\text { (1991a)/Colorado } \\
\text { Division of Water } \\
\text { Resources; consul- } \\
\text { tants' reports; } \\
\text { R. Madole (U.S. } \\
\text { Geological Survey, } \\
\text { oral commun., 2002) }\end{array}$ \\
\hline $\begin{array}{l}\text { United States/ } \\
\text { Colorado/ } \\
37.35 \mathrm{~N}, 106.54 \mathrm{~W}\end{array}$ & $\begin{array}{l}\text { Platoro/ } \\
\text { Conejos River }\end{array}$ & $\begin{array}{l}\text { Rockfill- } \\
\text { earthfill/ } \\
\text { Irrigation }\end{array}$ & $\begin{array}{l}\text { 1951/Federal } \\
\text { government }\end{array}$ & $50 / 270$ & 83.6 & $\begin{array}{l}\text { Massive } \\
\text { slump } \\
\text { block }\end{array}$ & $\begin{array}{l}\text { Left } \\
\text { abutment }\end{array}$ & $\begin{array}{l}\text { Left abutment is toe of large (length }>1 \mathrm{~km} \text { ) } \\
\text { andesite slump block. Abutment is stable. No } \\
\text { seepage problems. }\end{array}$ & $\begin{array}{l}\text { None/U.S. Bureau } \\
\text { of Reclamation; } \\
\text { Colorado Division of } \\
\text { Water Resources }\end{array}$ \\
\hline $\begin{array}{l}\text { United States/ } \\
\text { Colorado/ } \\
40.13 \mathrm{~N}, 107.26 \mathrm{~W}\end{array}$ & $\begin{array}{l}\text { Poose Creek/ } \\
\text { Poose Creek }\end{array}$ & $\begin{array}{l}\text { Earthfill/ } \\
\text { Recreation, } \\
\text { fish and } \\
\text { wildlife }\end{array}$ & $\begin{array}{l}\text { 1969/State } \\
\text { government }\end{array}$ & $12 / 133$ & 0.67 & $\begin{array}{l}\text { Slide in } \\
\text { volcanics, } \\
\text { shale, } \\
\text { glacial } \\
\text { deposits }\end{array}$ & $\begin{array}{l}\text { Right } \\
\text { abutment } \\
\text { (possibly } \\
\text { entire dam) }\end{array}$ & $\begin{array}{l}\text { Dam was built on mixture of landslide/glacial } \\
\text { deposits left behind as glacier retreated from } \\
\text { valley. Slide is a mixture of shale/sandstone } \\
\text { (Browns Park, Morrison, and Dakota Fms.), of } \\
\text { overlying Tertiary volcanics, and glacial depos- } \\
\text { its. No negative effects on dam. }\end{array}$ & $\begin{array}{l}\text { Colton and others } \\
\text { (1975f), Madole } \\
\text { (1989)/Colorado } \\
\text { Division of Water } \\
\text { Resources; R. Madole } \\
\text { (U.S. Geological } \\
\text { Survey, oral com- } \\
\text { mun., 2002) }\end{array}$ \\
\hline $\begin{array}{l}\text { United States/ } \\
\text { Colorado/ } \\
38.15 \mathrm{~N}, 107.75 \mathrm{~W}\end{array}$ & $\begin{array}{l}\text { Ridgway/ } \\
\text { Uncompahgre } \\
\text { River }\end{array}$ & $\begin{array}{l}\text { Earthfill/ } \\
\text { Irrigation, } \\
\text { water supply, } \\
\text { recreation, } \\
\text { flood control }\end{array}$ & $\begin{array}{l}\text { 1987/Federal } \\
\text { government }\end{array}$ & $101 / 740$ & 101 & $\begin{array}{l}\text { Slides in } \\
\text { siltstone, } \\
\text { sand- } \\
\text { stone, and } \\
\text { mudstone }\end{array}$ & $\begin{array}{l}\text { Left } \\
\text { abutment }\end{array}$ & $\begin{array}{l}\text { Relatively small slide masses uncovered during } \\
\text { construction; minor sliding occurred. Most slide } \\
\text { debris then removed. Remainder buttressed by } \\
\text { dam embankment; thus, the abutment is stron- } \\
\text { ger than originally. }\end{array}$ & $\begin{array}{l}\text { Von Thun (1987)/ } \\
\text { U.S. Bureau of } \\
\text { Reclamation }\end{array}$ \\
\hline
\end{tabular}


Appendix table A. Dam characteristics, relation to landslides, mitigative measures, and cited references-Continued

\begin{tabular}{|c|c|c|c|c|c|c|c|c|c|}
\hline $\begin{array}{l}\text { Country/ } \\
\text { state } \\
\text { or province/ } \\
\text { latitude, } \\
\text { longitude }\end{array}$ & $\begin{array}{l}\text { Dam/river } \\
\text { or stream }\end{array}$ & $\begin{array}{l}\text { Dam type/ } \\
\text { purpose }\end{array}$ & $\begin{array}{l}\text { Year } \\
\text { constructed/ } \\
\text { owner }\end{array}$ & $\begin{array}{l}\text { Height/ } \\
\text { length } \\
\text { (m) }\end{array}$ & $\begin{array}{l}\text { Storage } \\
\text { volume } \\
\left(\mathrm{Mm}^{3}\right)\end{array}$ & $\begin{array}{l}\text { Landslide } \\
\text { type }\end{array}$ & $\begin{array}{l}\text { Landslide } \\
\text { position } \\
\text { relative } \\
\text { to dam }\end{array}$ & Comments & $\begin{array}{l}\text { References/ } \\
\text { sources } \\
\text { of } \\
\text { information }\end{array}$ \\
\hline $\begin{array}{l}\text { United States/ } \\
\text { Colorado/ } \\
37.72 \mathrm{~N}, 107.27 \mathrm{~W}\end{array}$ & $\begin{array}{l}\text { Rio Grande/ } \\
\text { Rio Grande } \\
\text { River }\end{array}$ & $\begin{array}{l}\text { Earthfill/ } \\
\text { Irrigation }\end{array}$ & 1916/Private & $35 / 329$ & 64.4 & Rock slide & $\begin{array}{l}\text { Left } \\
\text { abutment }\end{array}$ & $\begin{array}{l}\text { Huge andesite slide at and above left abutment } \\
\text { (Atwood, 1918). Considerable seepage led to re- } \\
\text { construction of abutment featuring: (1) retaining } \\
\text { wall, (2) french drains, and (3) horizontal drains. } \\
\text { Installation of piezometers and inclinometers. }\end{array}$ & $\begin{array}{l}\text { Atwood (1918, p. } \\
\text { 18-20), Atwood } \\
\text { and Mather (1932, } \\
\text { p. 157)/Colorado } \\
\text { Division of Water } \\
\text { Resources; consul- } \\
\text { tants' reports }\end{array}$ \\
\hline $\begin{array}{l}\text { United States/ } \\
\text { Colorado/ } \\
40.14 \mathrm{~N}, 106.20 \mathrm{~W}\end{array}$ & $\begin{array}{l}\text { Scholl/Corral } \\
\text { Creek }\end{array}$ & $\begin{array}{l}\text { Earthfill/ } \\
\text { Irrigation }\end{array}$ & 1964/Private & $18 / 55$ & 0.8 & Rock slide & $\begin{array}{l}\text { Right } \\
\text { abutment }\end{array}$ & $\begin{array}{l}\text { Right end of dam abuts against slide of basalt } \\
\text { boulders up to } 2 \mathrm{~m} \text { in diameter derived from } \\
\text { basalt flows in upper valley wall. Serious seepage } \\
\text { through this pervious mass. In 1964, right groin } \\
\text { was grouted. In 1965, 1972, 1989-90, imperme- } \\
\text { able membranes were placed in right abutment, } \\
\text { but seepage continued; sinkholes formed on } \\
\text { surface. }\end{array}$ & $\begin{array}{l}\text { Colton and others } \\
\text { (1975f), Madole } \\
\text { (1991a)/Colorado } \\
\text { Division of Water } \\
\text { Resources; R. Mad- } \\
\text { ole (U.S. Geological } \\
\text { Survey, oral com- } \\
\text { mun., 2002) }\end{array}$ \\
\hline $\begin{array}{l}\text { United States/ } \\
\text { Colorado/ } \\
40.15 \mathrm{~N}, 107.14 \mathrm{~W}\end{array}$ & $\begin{array}{l}\text { Sheriff/ } \\
\text { Trout Creek }\end{array}$ & $\begin{array}{l}\text { Earthfill/ } \\
\text { Irrigation }\end{array}$ & $\begin{array}{l}\text { 1955/Local } \\
\text { government }\end{array}$ & $20 / 192$ & 1.8 & Rock slide & $\begin{array}{l}\text { Right } \\
\text { abutment }\end{array}$ & $\begin{array}{l}\text { Right valley wall is huge Quaternary landslide } \\
\text { mass, probably formed after glacier retreat. No } \\
\text { problems. }\end{array}$ & $\begin{array}{l}\text { Colton and others } \\
\text { (1975d)/Colorado } \\
\text { Division of Water } \\
\text { Resources }\end{array}$ \\
\hline $\begin{array}{l}\text { United States/ } \\
\text { Colorado/ } \\
38.25 \mathrm{~N}, 107.54 \mathrm{~W}\end{array}$ & $\begin{array}{l}\text { Silver Jack/ } \\
\text { East Fork } \\
\text { Cimarron } \\
\text { River }\end{array}$ & $\begin{array}{l}\text { Earthfill/ } \\
\text { Irrigation }\end{array}$ & $\begin{array}{l}\text { 1971/Federal } \\
\text { government }\end{array}$ & $53 / 320$ & 18.9 & $\begin{array}{l}\text { Huge } \\
\text { rock slide } \\
\text { in valley } \\
\text { wall }\end{array}$ & $\begin{array}{l}\text { Right } \\
\text { abutment }\end{array}$ & $\begin{array}{l}\text { Excavations for right end of dam were made in } \\
\text { toe of slide, causing } 375,000-\mathrm{m}^{3} \text { slide reactiva- } \\
\text { tion. Remedial measures: (1) resloping slide, }(2) \\
\text { redesigning dam to avoid further cutting at toe of } \\
\text { slide, }(3) \text { horizontal and surface drains, and (4) } \\
87,000-\mathrm{m}^{3} \text { buttress fill. Results were successful. }\end{array}$ & $\begin{array}{l}\text { Logan and Davis } \\
(1972), \text { Colton and } \\
\text { others }(1975 \mathrm{~g}) / \mathrm{U} . \mathrm{S} \text {. } \\
\text { Bureau of Reclama- } \\
\text { tion }\end{array}$ \\
\hline $\begin{array}{l}\text { United States/ } \\
\text { Colorado/ } \\
40.03 \mathrm{~N}, 107.12 \mathrm{~W}\end{array}$ & $\begin{array}{l}\text { Stillwater } \\
\text { No. 1/Bear } \\
\text { River }\end{array}$ & $\begin{array}{l}\text { Earthfill/ } \\
\text { Irrigation }\end{array}$ & 1939/Private & $27 / 457$ & 9.1 & $\begin{array}{l}\text { Massive } \\
\text { rock slides }\end{array}$ & $\begin{array}{l}\text { Entire dam } \\
\text { and reservoir }\end{array}$ & $\begin{array}{l}\text { Massive Quaternary rock slides filled valley after } \\
\text { glacier retreat. Dam built on toes of slides. No } \\
\text { problems. }\end{array}$ & $\begin{array}{l}\text { Colton and others } \\
(1975 f) / C o l o r a d o \\
\text { Geological Survey }\end{array}$ \\
\hline
\end{tabular}


Appendix table A. Dam characteristics, relation to landslides, mitigative measures, and cited references-Continued.

\begin{tabular}{|c|c|c|c|c|c|c|c|c|c|}
\hline $\begin{array}{l}\text { Country/ } \\
\text { state } \\
\text { or province/ } \\
\text { latitude, } \\
\text { longitude }\end{array}$ & $\begin{array}{l}\text { Dam/river } \\
\text { or stream }\end{array}$ & $\begin{array}{c}\text { Dam type/ } \\
\text { purpose }\end{array}$ & $\begin{array}{l}\text { Year } \\
\text { constructed/ } \\
\text { owner }\end{array}$ & $\begin{array}{l}\text { Height/ } \\
\text { length } \\
\text { (m) }\end{array}$ & $\begin{array}{c}\text { Storage } \\
\text { volume } \\
\left(\mathrm{Mm}^{3}\right)\end{array}$ & $\begin{array}{l}\text { Landslide } \\
\text { type }\end{array}$ & $\begin{array}{l}\text { Landslide } \\
\text { position } \\
\text { relative to } \\
\text { dam }\end{array}$ & Comments & $\begin{array}{l}\text { References/ } \\
\text { sources } \\
\text { of } \\
\text { information }\end{array}$ \\
\hline $\begin{array}{l}\text { United States/ } \\
\text { Colorado/ } \\
38.81 \mathrm{~N}, 106.60 \mathrm{~W}\end{array}$ & $\begin{array}{l}\text { Taylor Park/ } \\
\text { Taylor River }\end{array}$ & $\begin{array}{l}\text { Earthfill/ } \\
\text { Irrigation, } \\
\text { recreation }\end{array}$ & $\begin{array}{l}\text { 1937/Federal } \\
\text { government }\end{array}$ & $63 / 188$ & 1.39 & $\begin{array}{l}\text { Thick } \\
\text { talus cone }\end{array}$ & $\begin{array}{l}\text { Right } \\
\text { abutment }\end{array}$ & $\begin{array}{l}\text { Right abutment covered by thick talus cone from } \\
\text { sedimentary rock cliffs. Talus removed before } \\
\text { construction except for area } \sim 25 \text { m downstream } \\
\text { from centerline to downstream toe. }\end{array}$ & $\begin{array}{l}\text { None/U.S. Bureau } \\
\text { of Reclamation }\end{array}$ \\
\hline $\begin{array}{l}\text { United States/ } \\
\text { Colorado/ } \\
37.01 \mathrm{~N}, 106.45 \mathrm{~W}\end{array}$ & $\begin{array}{l}\text { Trujillo } \\
\text { Meadows/ } \\
\text { Los Piños } \\
\text { River }\end{array}$ & $\begin{array}{l}\text { Earthfill/ } \\
\text { Recreation }\end{array}$ & $\begin{array}{l}\text { 1956/State } \\
\text { government }\end{array}$ & $15 / 50$ & 1.6 & $\begin{array}{l}\text { Rock slide } \\
\text { in tuffs } \\
\text { and ash } \\
\text { flows }\end{array}$ & $\begin{array}{l}\text { Left } \\
\text { abutment } \\
\text { and } \\
\text { foundation }\end{array}$ & $\begin{array}{l}\text { Dam built on toe of large Quaternary rock slide } \\
\text { that had blocked the river. No stability problems, } \\
\text { but in 1990s seepage through left abutment } \\
\text { became unacceptable. Impervious cutoff placed } \\
\text { through left abutment in } 1998 \text {. }\end{array}$ & $\begin{array}{l}\text { Colton and others } \\
(1975 a), \text { Lipman } \\
\text { (1975)/Colorado } \\
\text { Division of Water } \\
\text { Resources; U.S. } \\
\text { Forest Service }\end{array}$ \\
\hline $\begin{array}{l}\text { United States/ } \\
\text { Colorado/ } \\
40.04 \mathrm{~N}, 107.07 \mathrm{~W}\end{array}$ & $\begin{array}{l}\text { Upper Still- } \\
\text { water/ } \\
\text { Bear River }\end{array}$ & $\begin{array}{l}\text { Earthfill/ Rec- } \\
\text { reation, fish } \\
\text { and wildlife }\end{array}$ & $\begin{array}{l}\text { 1965/State } \\
\text { government }\end{array}$ & $12 / 84$ & 1.3 & $\begin{array}{l}\text { Slide in } \\
\text { volcanic } \\
\text { rock, } \\
\text { shale, and } \\
\text { glacial } \\
\text { deposits }\end{array}$ & $\begin{array}{l}\text { Entire dam } \\
\text { on landslide } \\
\text { and glacial } \\
\text { deposits }\end{array}$ & $\begin{array}{l}\text { Valley walls are covered by massive Quaternary } \\
\text { landslides (mixtures of sandstone and shale } \\
\text { from Browns Park and Morrison Fms.), Tertiary } \\
\text { volcanics, and glacial deposits. At damsite, } \\
\text { landslide and glacial deposits are intermingled. } \\
\text { No dam problems related to geology. }\end{array}$ & $\begin{array}{l}\text { Colton and others } \\
\text { (1975f); Madole } \\
\text { (1989)/Colorado } \\
\text { Division of Water } \\
\text { Resources; } \\
\text { R. Madole (U.S. } \\
\text { Geological Survey, } \\
\text { oral commun., } \\
\text { 2002) }\end{array}$ \\
\hline $\begin{array}{l}\text { United States/ } \\
\text { Colorado/ } \\
39.23 \mathrm{~N}, 107.82 \mathrm{~W}\end{array}$ & $\begin{array}{l}\text { Vega/ } \\
\text { Plateau Creek }\end{array}$ & $\begin{array}{l}\text { Rockfill and } \\
\text { earthfill/ } \\
\text { Irrigation }\end{array}$ & $\begin{array}{l}\text { 1959/Federal } \\
\text { government }\end{array}$ & $49 / 640$ & 39.3 & $\begin{array}{l}\text { "Old land- } \\
\text { slide" }\end{array}$ & $\begin{array}{l}\text { Right } \\
\text { abutment }\end{array}$ & $\begin{array}{l}\text { Much of right abutment area is part of large } \\
\text { Quaternary landslide (Soule, 1986). In 1984, a } \\
\text { small part reactivated, slightly damaging spill- } \\
\text { way. No current activity. }\end{array}$ & $\begin{array}{l}\text { Colton and others } \\
(1975 \text { c), Soule } \\
\text { (1986)/U.S. Bureau } \\
\text { of Reclamation }\end{array}$ \\
\hline $\begin{array}{l}\text { United States/ } \\
\text { Colorado/ } \\
39.06 \mathrm{~N}, 107.87 \mathrm{~W}\end{array}$ & $\begin{array}{l}\text { Vela/Surface } \\
\text { Creek tribu- } \\
\text { tary }\end{array}$ & $\begin{array}{l}\text { Earthfill/ } \\
\text { Irrigation }\end{array}$ & 1959/Private & 12/191 & 0.7 & $\begin{array}{l}\text { Massive } \\
\text { rock slide }\end{array}$ & $\begin{array}{l}\text { Entire } \\
\text { dam and } \\
\text { reservoir }\end{array}$ & $\begin{array}{l}\text { Entire dam and reservoir are on Grand Mesa } \\
\text { landslide complex (mainly basalt on claystone, } \\
\text { mantled by glacial deposits). Minor foundation } \\
\text { seepage. Local slide problems at spillway. }\end{array}$ & $\begin{array}{l}\text { Yeend }(1969,1973), \\
\text { Colton and others } \\
(1975 \text { c }), \text { Baum } \\
\text { and Odum }(1996, \\
\text { 2003)/ Colorado } \\
\text { Division of Water } \\
\text { Resources }\end{array}$ \\
\hline
\end{tabular}


Appendix table A. Dam characteristics, relation to landslides, mitigative measures, and cited references-Continued.

\begin{tabular}{|c|c|c|c|c|c|c|c|c|c|}
\hline $\begin{array}{l}\text { Country/ } \\
\text { state } \\
\text { or province/ } \\
\text { latitude, } \\
\text { longitude }\end{array}$ & $\begin{array}{l}\text { Dam/river } \\
\text { or stream }\end{array}$ & $\begin{array}{l}\text { Dam type/ } \\
\text { purpose }\end{array}$ & $\begin{array}{l}\text { Year } \\
\text { constructed/ } \\
\text { owner }\end{array}$ & $\begin{array}{l}\text { Height/ } \\
\text { length } \\
\text { (m) }\end{array}$ & $\begin{array}{l}\text { Storage } \\
\text { volume } \\
\left(\mathrm{Mm}^{3}\right)\end{array}$ & $\begin{array}{l}\text { Landslide } \\
\text { type }\end{array}$ & $\begin{array}{l}\text { Landslide } \\
\text { position } \\
\text { relative to } \\
\text { dam }\end{array}$ & Comments & $\begin{array}{l}\text { References/ } \\
\text { sources } \\
\text { of } \\
\text { information }\end{array}$ \\
\hline $\begin{array}{l}\text { United States/ } \\
\text { Colorado/ } \\
39.01 \mathrm{~N}, 108.00 \mathrm{~W}\end{array}$ & $\begin{array}{l}\text { Ward Creek/ } \\
\text { Ward Creek }\end{array}$ & $\begin{array}{l}\text { Earthfill/ } \\
\text { Irrigation, } \\
\text { recreation }\end{array}$ & 1957/Private & $14 / 384$ & 0.7 & $\begin{array}{l}\text { Massive } \\
\text { rock slide }\end{array}$ & $\begin{array}{l}\text { Entire } \\
\text { dam and } \\
\text { reservoir }\end{array}$ & $\begin{array}{l}\text { Entire dam and reservoir are on Grand Mesa } \\
\text { landslide complex (mainly basalt on clay- } \\
\text { stone, mantled by glacial deposits). }\end{array}$ & $\begin{array}{l}\text { Yeend }(1969,1973), \\
\text { Colton and others } \\
(1975 c), \text { Baum and } \\
\text { Odum }(1996,2003) / \\
\text { Colorado Division of } \\
\text { Water Resources }\end{array}$ \\
\hline $\begin{array}{l}\text { United States/ } \\
\text { Colorado/ } \\
40.33 \mathrm{~N}, 106.52 \mathrm{~W}\end{array}$ & $\begin{array}{l}\text { Whiteley } \\
\text { Peak/ Dia- } \\
\text { mond Creek }\end{array}$ & $\begin{array}{l}\text { Earthfill/ } \\
\text { Irrigation, } \\
\text { water supply }\end{array}$ & 1952/Private & $19 / 236$ & 1.6 & $\begin{array}{l}\text { Shale } \\
\text { slide }\end{array}$ & Entire dam & $\begin{array}{l}\text { Slides in Pierre Shale form both abutments } \\
\text { and foundation of dam. Reactivation of part } \\
\text { of right abutment slide in } 1986 \text { slightly dam- } \\
\text { aged spillway. No other serious effects. }\end{array}$ & $\begin{array}{l}\text { Hail (1968), Colton } \\
\text { and others (1975f), } \\
\text { Madole (1991a)/ } \\
\text { Colorado Division of } \\
\text { Water Resources; } \\
\text { R. Madole (U.S. } \\
\text { Geological Survey, } \\
\text { oral commun., 2002) }\end{array}$ \\
\hline $\begin{array}{l}\text { United States/ } \\
\text { Colorado/ } \\
40.55 \mathrm{~N}, 107.05 \mathrm{~W}\end{array}$ & $\begin{array}{l}\text { Yamcolo/ } \\
\text { Bear River }\end{array}$ & $\begin{array}{l}\text { Earthfill/ } \\
\text { Irrigation, } \\
\text { water supply }\end{array}$ & $\begin{array}{l}\text { 1980/Local } \\
\text { government }\end{array}$ & $\begin{array}{l}34 / \\
1,214\end{array}$ & 14.9 & $\begin{array}{l}\text { Rock slide } \\
\text { and debris } \\
\text { flow }\end{array}$ & $\begin{array}{l}\text { Both } \\
\text { abutments }\end{array}$ & $\begin{array}{l}\text { Right end of dam on huge Quaternary rock } \\
\text { slide; left end and part of left foundation on } \\
\text { Quaternary debris flow. No problems. }\end{array}$ & $\begin{array}{l}\text { Colton and others } \\
\text { (1975f)/Colorado } \\
\text { Geological Survey; } \\
\text { Colorado Division of } \\
\text { Water Resources }\end{array}$ \\
\hline $\begin{array}{l}\text { United States/ } \\
\text { Colorado/ } \\
39.04 \mathrm{~N}, 107.91 \mathrm{~W}\end{array}$ & $\begin{array}{l}\text { Young's } \\
\text { Creek Nos. } \\
1 \text { and } 2 \\
\text { (one dam)/ } \\
\text { Young's } \\
\text { Creek tribu- } \\
\text { tary }\end{array}$ & $\begin{array}{l}\text { Earthfill/ } \\
\text { Irrigation }\end{array}$ & 1952/Private & $17 / 154$ & 1.0 & Rock slide & $\begin{array}{l}\text { Foundation } \\
\text { and } \\
\text { abutments }\end{array}$ & $\begin{array}{l}\text { Entire dam and reservoir are on Grand } \\
\text { Mesa landslide complex (mainly basalt on } \\
\text { claystone, mantled by glacial deposits). Some } \\
\text { seepage at both abutments. Left abutment } \\
\text { has been grouted (with little success). Local } \\
\text { blanketing with membranes tried without } \\
\text { long-term success. Dam is stable. }\end{array}$ & $\begin{array}{l}\text { Yeend }(1969,1973), \\
\text { Colton and others } \\
(1975 c), \text { Baum and } \\
\text { Odum }(1996,2003) / \\
\text { Colorado Division of } \\
\text { Water Resources }\end{array}$ \\
\hline
\end{tabular}


Appendix table A. Dam characteristics, relation to landslides, mitigative measures, and cited references-Continued.

\begin{tabular}{|c|c|c|c|c|c|c|c|c|c|}
\hline $\begin{array}{l}\text { Country/ } \\
\text { state } \\
\text { or province/ } \\
\text { latitude, } \\
\text { longitude }\end{array}$ & $\begin{array}{l}\text { Dam/river } \\
\text { or stream }\end{array}$ & $\begin{array}{l}\text { Dam type/ } \\
\text { purpose }\end{array}$ & $\begin{array}{c}\text { Year } \\
\text { constructed/ } \\
\text { owner }\end{array}$ & $\begin{array}{l}\text { Height/ } \\
\text { length } \\
\text { (m) }\end{array}$ & $\begin{array}{c}\text { Storage } \\
\text { volume } \\
\left(\mathrm{Mm}^{3}\right)\end{array}$ & $\begin{array}{l}\text { Landslide } \\
\text { type }\end{array}$ & $\begin{array}{l}\text { Landslide } \\
\text { position } \\
\text { relative to } \\
\text { dam }\end{array}$ & Comments & $\begin{array}{l}\text { References/ } \\
\text { sources } \\
\text { of } \\
\text { information }\end{array}$ \\
\hline $\begin{array}{l}\text { United States/ } \\
\text { Colorado/ } \\
39.19 \mathrm{~N}, 107.89\end{array}$ & $\begin{array}{l}\text { YT Ranch/ } \\
\text { Grove Creek }\end{array}$ & $\begin{array}{l}\text { Earthfill/ } \\
\text { Recreation, } \\
\text { irrigation }\end{array}$ & 1911/Private & $12 / 274$ & 0.3 & $\begin{array}{l}\text { "Old de- } \\
\text { bris flow" }\end{array}$ & $\begin{array}{l}\text { Entire dam } \\
\text { and reservoir }\end{array}$ & $\begin{array}{l}\text { Entire dam and reservoir are on "old debris } \\
\text { flow" that originated on Grand Mesa (Soule, } \\
\text { 1988). Dam is stable, but has considerable } \\
\text { seepage through foundation. }\end{array}$ & $\begin{array}{l}\text { Colton and oth- } \\
\text { ers (1975c), Soule } \\
\text { (1988)/Colorado } \\
\text { Division of Water } \\
\text { Resources }\end{array}$ \\
\hline $\begin{array}{l}\text { United States/ } \\
\text { Idaho/ } \\
43.36 \mathrm{~N}, 115.44 \mathrm{~W}\end{array}$ & $\begin{array}{l}\text { Anderson } \\
\text { Ranch/South } \\
\text { Fork Boise } \\
\text { River }\end{array}$ & $\begin{array}{l}\text { Earthfill-rock- } \\
\text { fill/Irrigation, } \\
\text { hydroelectric }\end{array}$ & $\begin{array}{l}\text { 1971/Federal } \\
\text { government }\end{array}$ & $139 / 411$ & 608 & $\begin{array}{l}\text { Rockfall } \\
\text { (talus) }\end{array}$ & $\begin{array}{l}\text { Right } \\
\text { abutment }\end{array}$ & $\begin{array}{l}\text { Before construction, right abutment was } \\
\text { covered by thick layer of basalt talus, which } \\
\text { was removed to granite bedrock under zone } \\
\text { 1. Partially removed ("engineered") under } \\
\text { upstream shell; left in place under downstream } \\
\text { shell. New landslide has occurred into reservoir } \\
\text { at upstream edge of "engineered" talus slope. } \\
\text { Seepage on right valley wall downstream from } \\
\text { dam apparently passes through talus. }\end{array}$ & $\begin{array}{l}\text { None/U.S. Bureau } \\
\text { of Reclamation }\end{array}$ \\
\hline $\begin{array}{l}\text { United States/ } \\
\text { Idaho/ } \\
43.33 \mathrm{~N}, 111.21 \mathrm{~W}\end{array}$ & $\begin{array}{l}\text { Palisades/ } \\
\text { Snake River }\end{array}$ & $\begin{array}{l}\text { Earthfill/ } \\
\text { Irrigation, } \\
\text { hydroelectric, } \\
\text { flood control, } \\
\text { recreation, fish } \\
\text { and wildlife }\end{array}$ & $\begin{array}{l}\text { 1957/Federal } \\
\text { government }\end{array}$ & $82 / 640$ & 1,800 & Rock slide & $\begin{array}{l}\text { Right } \\
\text { abutment }\end{array}$ & $\begin{array}{l}\text { Large slide at least } 10,000 \mathrm{yr} \text { old. Maximum } \\
\text { thickness } \sim 70 \mathrm{~m} \text {; width along upstream part of } \\
\text { right abutment and shore } \sim 1 \mathrm{~km} \text {. Landslide ma- } \\
\text { terial mainly andesite cobbles and boulders in } \\
\text { matrix of silt, sand, gravel. Closely monitored; } \\
\text { thus far, no movement. No problems. }\end{array}$ & $\begin{array}{l}\text { Oriel and Moore } \\
(1985) / \text { U.S. Bureau } \\
\text { of Reclamation }\end{array}$ \\
\hline $\begin{array}{l}\text { United States/ } \\
\text { Kansas/ } \\
39.81 \mathrm{~N}, 99.94 \mathrm{~W}\end{array}$ & $\begin{array}{l}\text { Lovewell/ } \\
\text { White Rock } \\
\text { Creek }\end{array}$ & $\begin{array}{l}\text { Earthfill/ } \\
\text { Flood control, } \\
\text { irrigation, } \\
\text { recreation }\end{array}$ & $\begin{array}{l}\text { 1957/Federal } \\
\text { government }\end{array}$ & $\begin{array}{l}28 / \\
2,590\end{array}$ & 230 & $\begin{array}{l}\text { Shale } \\
\text { slides }\end{array}$ & $\begin{array}{l}\text { Right } \\
\text { abutment }\end{array}$ & $\begin{array}{l}\text { Entire abutment slope above right end of dam } \\
\text { poses threat to dam. In } 1955 \text {, shale slide } \\
\text { occurred during construction; } 95,000 \mathrm{~m}^{3} \text { of } \\
\text { slide material was removed. Abutment now } \\
\text { buttressed by dam and two berms. However, } \\
\text { minor sliding continues in abutment above } \\
\text { dam. In 1985, instrumentation and monitoring } \\
\text { were recommended. }\end{array}$ & $\begin{array}{l}\text { None/U.S. Bureau } \\
\text { of Reclamation }\end{array}$ \\
\hline
\end{tabular}


Appendix table A. Dam characteristics, relation to landslides, mitigative measures, and cited references-Continued.

\begin{tabular}{|c|c|c|c|c|c|c|c|c|c|}
\hline $\begin{array}{c}\text { Country/ } \\
\text { state } \\
\text { or province/ } \\
\text { latitude, } \\
\text { longitude }\end{array}$ & $\begin{array}{l}\text { Dam/river } \\
\text { or stream }\end{array}$ & $\begin{array}{l}\text { Dam type/ } \\
\text { purpose }\end{array}$ & $\begin{array}{l}\text { Year } \\
\text { constructed/ } \\
\text { owner }\end{array}$ & $\begin{array}{l}\text { Height/ } \\
\text { length } \\
\text { (m) }\end{array}$ & $\begin{array}{c}\text { Storage } \\
\text { volume } \\
\left(\mathrm{Mm}^{3}\right)\end{array}$ & $\begin{array}{l}\text { Landslide } \\
\text { type }\end{array}$ & $\begin{array}{l}\text { Landslide } \\
\text { position } \\
\text { relative to } \\
\text { dam }\end{array}$ & Comments & $\begin{array}{l}\text { References/ } \\
\text { sources } \\
\text { of } \\
\text { information }\end{array}$ \\
\hline $\begin{array}{l}\text { United States/ } \\
\text { Kentucky/ } \\
\text { 36.96N, } 84.27 \mathrm{~W}\end{array}$ & $\begin{array}{l}\text { Laurel/ } \\
\text { Laurel Creek }\end{array}$ & $\begin{array}{l}\text { Rockfill/ } \\
\text { Flood control, } \\
\text { hydroelectric, } \\
\text { recreation }\end{array}$ & $\begin{array}{l}\text { 1973/Federal } \\
\text { government }\end{array}$ & $86 / 433$ & 537 & $\begin{array}{l}\text { Bedding- } \\
\text { plane } \\
\text { shears }\end{array}$ & $\begin{array}{l}\text { Both } \\
\text { abutments }\end{array}$ & $\begin{array}{l}\text { Pre-existing bedding-plane displacement caused by } \\
\text { stress relief in valley. Shear zones and fractures of } \\
\text { foundation rock at damsite were filled with grout as } \\
\text { part of grout curtain beneath core of dam. }\end{array}$ & $\begin{array}{l}\text { Radbruch-Hall and } \\
\text { Varnes (1976)/U.S. } \\
\text { Army Corps of } \\
\text { Engineers }\end{array}$ \\
\hline $\begin{array}{l}\text { United States/ } \\
\text { Kentucky/ } \\
38.00 \mathrm{~N}, 85.32 \mathrm{~W}\end{array}$ & $\begin{array}{l}\text { Taylorsville/ } \\
\text { Salt River }\end{array}$ & $\begin{array}{l}\text { Rockfill and } \\
\text { earthfill/Flood } \\
\text { control, } \\
\text { recreation }\end{array}$ & $\begin{array}{l}\text { 1983/Federal } \\
\text { government }\end{array}$ & $49 / 390$ & 360 & $\begin{array}{l}\text { Small pre- } \\
\text { existing } \\
\text { slide }\end{array}$ & $\begin{array}{l}\text { Left } \\
\text { abutment }\end{array}$ & $\begin{array}{l}\text { Small pre-existing slide in sedimentary rocks at left } \\
\text { end of dam. Occasional minor movement of rock in } \\
\text { abutment immediately above end of dam; leads to } \\
\text { need for minor maintenance. No other problems. }\end{array}$ & $\begin{array}{l}\text { None/U.S. Army } \\
\text { Corps of Engineers }\end{array}$ \\
\hline $\begin{array}{l}\text { United States/ } \\
\text { Montana/ } \\
49.59 \mathrm{~N}, 114.28 \mathrm{~W}\end{array}$ & $\begin{array}{l}\text { Bass Lake/ } \\
\text { Bass Creek }\end{array}$ & $\begin{array}{l}\text { Earthfill/ } \\
\text { Irrigation }\end{array}$ & 1952/Private & $11 / 137$ & 4.4 & $\begin{array}{l}\text { Rock fall } \\
\text { (talus) }\end{array}$ & $\begin{array}{l}\text { Left } \\
\text { abutment }\end{array}$ & $\begin{array}{l}\text { Downstream left shell of dam placed on talus slope. } \\
\text { Remedial measure: sheetpiling for length of dam. }\end{array}$ & $\begin{array}{l}\text { None/Montana } \\
\text { Water Resources } \\
\text { Division; consultant's } \\
\text { report }\end{array}$ \\
\hline $\begin{array}{l}\text { United States/ } \\
\text { Montana/ } \\
47.20 \mathrm{~N}, 113.72 \mathrm{~W}\end{array}$ & $\begin{array}{l}\text { Black Lake/ } \\
\text { Jocko River }\end{array}$ & $\begin{array}{l}\text { Earthfill/ } \\
\text { Irrigation }\end{array}$ & $\begin{array}{l}\text { 1967/Federal } \\
\text { government }\end{array}$ & $26 / 166$ & 6.4 & $\begin{array}{l}\text { Rock slide } \\
\text { and talus }\end{array}$ & $\begin{array}{l}\text { Right } \\
\text { abutment }\end{array}$ & $\begin{array}{l}\text { Dam founded on ancient landslide dam. Consider- } \\
\text { able seepage through rock slide and talus. In } 1992 \text {, } \\
6 \text { ha of } 1.5 \text {-mm-thick polyethlylene membrane } \\
\text { protected by geotextiles was installed in slide/talus. } \\
\text { Abutment continues to leak. Downstream berm } \\
\text { being considered. }\end{array}$ & $\begin{array}{l}\text { None/U.S. Bureau } \\
\text { of Reclamation; } \\
\text { U.S. Bureau of Indian } \\
\text { Affairs }\end{array}$ \\
\hline $\begin{array}{l}\text { United States/ } \\
\text { Montana/ } \\
46.65 \mathrm{~N}, 111.73 \mathrm{~W}\end{array}$ & $\begin{array}{l}\text { Canyon Ferry } \\
\text { Dam/ } \\
\text { Missouri } \\
\text { River }\end{array}$ & $\begin{array}{l}\text { Concrete } \\
\text { gravity/ } \\
\text { Hydroelectric, } \\
\text { flood control, } \\
\text { irrigation, } \\
\text { water supply, } \\
\text { recreation }\end{array}$ & $\begin{array}{l}\text { 1954/Federal } \\
\text { government }\end{array}$ & $69 / 328$ & 2,529 & $\begin{array}{l}\text { Bedding- } \\
\text { plane slip } \\
\text { in shale }\end{array}$ & $\begin{array}{l}\text { Left } \\
\text { abutment }\end{array}$ & $\begin{array}{l}\text { Several left-abutment bedding-plane slips in shale } \\
\text { were excavated to competent bedrock. However, } \\
\text { one prominent slip was only partially removed } \\
\text { providing a short path for reservoir water to enter } \\
\text { foundation. Remedial measure: two cutoff tunnels } \\
\text { were placed parallel to dam axis and filled with } \\
\text { concrete; they apparently were successful. }\end{array}$ & $\begin{array}{l}\text { None/U.S. Bureau } \\
\text { of Reclamation }\end{array}$ \\
\hline $\begin{array}{l}\text { United States/ } \\
\text { Montana/ } \\
45.49 \mathrm{~N}, 110.98 \mathrm{~W}\end{array}$ & $\begin{array}{l}\text { Hyalite (Mid- } \\
\text { dle Creek)/ } \\
\text { Hyalite Creek }\end{array}$ & $\begin{array}{l}\text { Earthfill/ } \\
\text { Irrigation, } \\
\text { water supply }\end{array}$ & $\begin{array}{l}\text { 1951/State } \\
\text { government }\end{array}$ & $38 / 580$ & 15.8 & $\begin{array}{l}\text { Slide in } \\
\text { glacial } \\
\text { debris }\end{array}$ & $\begin{array}{l}\text { Left } \\
\text { abutment }\end{array}$ & $\begin{array}{l}\text { Geotechnical consultant to State of Montana identi- } \\
\text { fied left abutment as being "founded on mixed } \\
\text { landslide and glacial deposits composed of clay, } \\
\text { silt, sand, poorly sorted gravel, rock fragments, } \\
\text { conglomerate, and boulders." During 1990s, com- } \\
\text { pacted earth liner placed to lower seepage rate. No } \\
\text { stability problem. }\end{array}$ & $\begin{array}{l}\text { None/Montana } \\
\text { Water Resources } \\
\text { Division; consultant's } \\
\text { report }\end{array}$ \\
\hline
\end{tabular}


Appendix table A. Dam characteristics, relation to landslides, mitigative measures, and cited references-Continued.

\begin{tabular}{|c|c|c|c|c|c|c|c|c|c|}
\hline $\begin{array}{l}\text { Country/ } \\
\text { state } \\
\text { or province/ } \\
\text { latitude, } \\
\text { longitude }\end{array}$ & $\begin{array}{l}\text { Dam/river } \\
\text { or stream }\end{array}$ & $\begin{array}{c}\text { Dam type/ } \\
\text { purpose }\end{array}$ & $\begin{array}{l}\text { Year } \\
\text { constructed/ } \\
\text { owner }\end{array}$ & $\begin{array}{l}\text { Height/ } \\
\text { length } \\
\text { (m) }\end{array}$ & $\begin{array}{l}\text { Storage } \\
\text { volume } \\
\left(\mathrm{Mm}^{3}\right)\end{array}$ & $\begin{array}{c}\text { Landslide } \\
\text { type }\end{array}$ & $\begin{array}{l}\text { Landslide } \\
\text { position } \\
\text { relative to } \\
\text { dam }\end{array}$ & Comments & $\begin{array}{l}\text { References/ } \\
\text { sources } \\
\text { of } \\
\text { information }\end{array}$ \\
\hline $\begin{array}{l}\text { United States/ } \\
\text { Montana/ } \\
48.83 \mathrm{~N}, 113.52 \mathrm{~W}\end{array}$ & $\begin{array}{l}\text { Lake Sher- } \\
\text { burne/Swift- } \\
\text { current } \\
\text { Creek }\end{array}$ & $\begin{array}{l}\text { Earthfill/ } \\
\text { Irrigation }\end{array}$ & $\begin{array}{l}\text { 1921/Federal } \\
\text { government }\end{array}$ & $33 / 366$ & 136.5 & $\begin{array}{l}\text { Slide in } \\
\text { glacial } \\
\text { deposits }\end{array}$ & $\begin{array}{l}\text { Both } \\
\text { abutments }\end{array}$ & $\begin{array}{l}\text { Valley walls: massive landslide debris derived } \\
\text { mainly from glacial deposits. Original foundation } \\
\text { treatment included three continuous cutoff trenches } \\
\text { reaching into till across valley bottom. Prior to } \\
\text { 1960, movement of left abutment damaged original } \\
\text { spillway; abutment remains unstable. Monitoring } \\
\text { continues. }\end{array}$ & $\begin{array}{l}\text { Lowe (1988), } \\
\text { Carrara (1990), } \\
\text { Whipple (1992)/ } \\
\text { U.S. Bureau of } \\
\text { Reclamation }\end{array}$ \\
\hline $\begin{array}{l}\text { United States/ } \\
\text { Montana/ } \\
46.56 \mathrm{~N}, 113.31 \mathrm{~W}\end{array}$ & $\begin{array}{l}\text { Lower Willow } \\
\text { Creek/Lower } \\
\text { Willow Creek }\end{array}$ & $\begin{array}{l}\text { Earthfill/ } \\
\text { Irrigation }\end{array}$ & $\begin{array}{l}\text { 1962/Local } \\
\text { government }\end{array}$ & 29/296 & 7.7 & $\begin{array}{l}\text { Rock fall } \\
\text { (mainly } \\
\text { talus) }\end{array}$ & $\begin{array}{l}\text { Left } \\
\text { abutment }\end{array}$ & $\begin{array}{l}\text { Considerable seepage through lower left abutment. } \\
\text { However, most seepage apparently is through } \\
\text { jointed quartzite and argillite, not through the } \\
\text { talus/colluvium. }\end{array}$ & $\begin{array}{l}\text { None/U.S. Natural } \\
\text { Resources Conser- } \\
\text { vation Service }\end{array}$ \\
\hline $\begin{array}{l}\text { United States/ } \\
\text { Montana/ } \\
45.49 \mathrm{~N}, 111.64 \mathrm{~W}\end{array}$ & $\begin{array}{l}\text { Madison/ } \\
\text { Madison } \\
\text { River }\end{array}$ & $\begin{array}{l}\text { Concrete } \\
\text { gravity/Hydro- } \\
\text { electric, } \\
\text { flood control, } \\
\text { water supply, } \\
\text { recreation }\end{array}$ & $\begin{array}{l}1907 / \\
\text { Hydroelectric } \\
\text { power com- } \\
\text { pany }\end{array}$ & $12 / 78$ & 52 & $\begin{array}{l}\text { Rock } \\
\text { slides }\end{array}$ & $\begin{array}{l}\text { Right } \\
\text { abutment }\end{array}$ & $\begin{array}{l}\text { Right abutment is in toe of pre-existing slide in } \\
\text { metamorphic rock. Steel piles and concrete buttress } \\
\text { used to anchor right abutment. }\end{array}$ & $\begin{array}{l}\text { None/Site visit; } \\
\text { C. Ruleman (oral } \\
\text { commun., 2002) }\end{array}$ \\
\hline $\begin{array}{l}\text { United States/ } \\
\text { Montana/ } \\
45.54 \mathrm{~N}, 110.92 \mathrm{~W}\end{array}$ & $\begin{array}{l}\text { Mystic Lake/ } \\
\text { Bozeman } \\
\text { Creek }\end{array}$ & $\begin{array}{l}\text { Earthfill/ } \\
\text { Irrigation, } \\
\text { water supply }\end{array}$ & 1904/Private & $13 / 119$ & 1.5 & $\begin{array}{l}\text { Flow in } \\
\text { volcanic } \\
\text { breccia }\end{array}$ & $\begin{array}{l}\text { Left } \\
\text { abutment } \\
\text { and left } \\
\text { end of } \\
\text { foundation }\end{array}$ & $\begin{array}{l}\text { Flow of volcanic breccia dammed Bozeman Creek } \\
\sim 200 \mathrm{yr} \text { B.P. This landslide formed left abutment } \\
\text { and left end of dam foundation. Dam was purposely } \\
\text { breached in } 1982 \text { and } 1985 \text { because of leakage and } \\
\text { risk to downstream population. }\end{array}$ & $\begin{array}{l}\text { Roberts (1964), } \\
\text { Hayes (1981), High } \\
\text { County Independent } \\
\text { Press (1985)/Re- } \\
\text { ports: consultants; } \\
\text { U.S. Army Corps } \\
\text { of Engineers; U.S. } \\
\text { Forest Service; } \\
\text { Bozeman Creek } \\
\text { Reservoir Associa- } \\
\text { tion }\end{array}$ \\
\hline
\end{tabular}


Appendix table A. Dam characteristics, relation to landslides, mitigative measures, and cited references-Continued.

\begin{tabular}{|c|c|c|c|c|c|c|c|c|c|}
\hline $\begin{array}{c}\text { Country/ } \\
\text { state } \\
\text { or province/ } \\
\text { latitude, } \\
\text { longitude }\end{array}$ & $\begin{array}{l}\text { Dam/river } \\
\text { or stream }\end{array}$ & $\begin{array}{l}\text { Dam type/ } \\
\text { purpose }\end{array}$ & $\begin{array}{c}\text { Year } \\
\text { constructed/ } \\
\text { owner }\end{array}$ & $\begin{array}{c}\text { Height/ } \\
\text { length } \\
\text { (m) }\end{array}$ & $\begin{array}{c}\text { Storage } \\
\text { volume } \\
\left(\mathrm{Mm}^{3}\right)\end{array}$ & $\begin{array}{l}\text { Landslide } \\
\text { type }\end{array}$ & $\begin{array}{l}\text { Landslide } \\
\text { position } \\
\text { relative to } \\
\text { dam }\end{array}$ & Comments & $\begin{array}{c}\text { References/ } \\
\text { sources } \\
\text { of } \\
\text { information }\end{array}$ \\
\hline $\begin{array}{l}\text { United States/ } \\
\text { Montana/ } \\
46.80 \mathrm{~N}, 112.81 \mathrm{~W}\end{array}$ & $\begin{array}{l}\text { Nevada } \\
\text { Creek/ } \\
\text { Nevada Creek }\end{array}$ & $\begin{array}{l}\text { Earthfill/ } \\
\text { Irrigation }\end{array}$ & $\begin{array}{l}\text { 1938/State } \\
\text { government }\end{array}$ & $32 / 330$ & 21.3 & $\begin{array}{l}\text { Rock and } \\
\text { earth slide }\end{array}$ & $\begin{array}{l}\text { Both } \\
\text { abutments; } \\
\text { much of } \\
\text { foundation }\end{array}$ & $\begin{array}{l}\text { Material underlying much of dam and against } \\
\text { which dam abuts at both ends is mass of irregular } \\
\text { boulders of basalt in clay. Mass is ancient landslide } \\
\text { that moved down valley slopes to stream channel. } \\
\text { Foundation is stable, but there has been seepage at } \\
\text { both abutments and under dam. Remedial measures: } \\
\text { (1) toe berm and (2) seepage collection system using } \\
\text { relief wells and shallow drains. }\end{array}$ & $\begin{array}{l}\text { Sanders and others } \\
\text { (2001)/U.S. Bureau } \\
\text { of Reclamation; } \\
\text { Montana Water } \\
\text { Resources Division; } \\
\text { consultants' reports }\end{array}$ \\
\hline $\begin{array}{l}\text { United States/ } \\
\text { New Mexico/ } \\
35.40 \mathrm{~N}, 104.19 \mathrm{~W}\end{array}$ & $\begin{array}{l}\text { Conchas/ } \\
\text { Canadian } \\
\text { River } \\
\text { (Conchas } \\
\text { River) }\end{array}$ & $\begin{array}{l}\text { Concrete } \\
\text { gravity- } \\
\text { rockfill/ } \\
\text { Irrigation, } \\
\text { recreation, } \\
\text { debris control }\end{array}$ & $\begin{array}{l}\text { 1940/Federal } \\
\text { government }\end{array}$ & $\begin{array}{l}72 / \\
5,944\end{array}$ & 874 & $\begin{array}{l}\text { Open } \\
\text { joints in } \\
\text { sandstone } \\
\text { and shale }\end{array}$ & $\begin{array}{l}\text { Both } \\
\text { abutments }\end{array}$ & $\begin{array}{l}\text { Valley walls consist of jointed (often slickensided) } \\
\text { sandstone and shale. As construction scaling } \\
\text { progressed to stable rock, new joints opened. To } \\
\text { prevent this, reinforced columns were used to act as } \\
\text { beams for lateral support. Today, dam acts as its own } \\
\text { buttress. }\end{array}$ & $\begin{array}{l}\text { Stratton (1938), } \\
\text { Crosby (1939)/None }\end{array}$ \\
\hline $\begin{array}{l}\text { United States/ } \\
\text { New Mexico/ } \\
36.88 \mathrm{~N}, 105.28 \mathrm{~W}\end{array}$ & $\begin{array}{l}\text { Costilla/ } \\
\text { Costilla River }\end{array}$ & $\begin{array}{l}\text { Earthfill/ } \\
\text { Irrigation }\end{array}$ & 1920/Private & $42 / 238$ & 37.5 & $\begin{array}{l}\text { Massive } \\
\text { landslide }\end{array}$ & $\begin{array}{l}\text { Right } \\
\text { abutment }\end{array}$ & $\begin{array}{l}\text { Right end of dam adjacent to toe of deep-seated } \\
\text { ancient landslide in volcaniclastics, which originally } \\
\text { were identified as glacial debris. In 1985, decision } \\
\text { was made to rehabilitate dam because of embank- } \\
\text { ment seepage. During reconstruction, reactivation } \\
\text { (volume: } 8-9 \text { million } \mathrm{m}^{3} \text { ) of landslide occurred. } \\
\text { Berm added for stability. Slide now stable. }\end{array}$ & $\begin{array}{l}\text { Dunn and Haneberg } \\
\text { (1998), Dunn (1999, } \\
\text { 2000), Haneberg } \\
\text { (1999)/U.S. Bureau } \\
\text { of Reclamation; } \\
\text { New Mexico State } \\
\text { Engineer }\end{array}$ \\
\hline $\begin{array}{l}\text { United States/ } \\
\text { New Mexico/ } \\
36.59 \mathrm{~N}, 106.75 \mathrm{~W}\end{array}$ & $\begin{array}{l}\text { El Vado/ } \\
\text { Chama River }\end{array}$ & $\begin{array}{l}\text { Earthfill with } \\
\text { steel-mem- } \\
\text { brane face/ } \\
\text { Irrigation, } \\
\text { water supply, } \\
\text { recreation }\end{array}$ & $\begin{array}{l}\text { 1935/Private } \\
\text { conservancy } \\
\text { district }\end{array}$ & $70 / 404$ & 258 & $\begin{array}{l}\text { Bedding- } \\
\text { plane rock } \\
\text { slide }\end{array}$ & $\begin{array}{l}\text { Left } \\
\text { abutment }\end{array}$ & $\begin{array}{l}\text { Left abutment and canyon wall for about } 1 \mathrm{~km} \text { up- } \\
\text { stream and downstream are large, ancient }(\sim 10,000 \\
\text { yr B.P.) slide in sandstone and shale. Major grouting } \\
\text { program in left abutment during construction. With- } \\
\text { in } 3 \text { years of reservoir filling, steel-plate membrane } \\
\text { buckled, possibly due to abutment deformation. } \\
\text { Repaired in 1955; stable since. }\end{array}$ & $\begin{array}{l}\text { Sherard and others } \\
(1963, \text { p. } 481-482) / \\
\text { U.S. Bureau of } \\
\text { Reclamation }\end{array}$ \\
\hline
\end{tabular}


Appendix table A. Dam characteristics, relation to landslides, mitigative measures, and cited references-Continued.

\begin{tabular}{|c|c|c|c|c|c|c|c|c|c|}
\hline $\begin{array}{l}\text { Country/ } \\
\text { state } \\
\text { or province/ } \\
\text { latitude, } \\
\text { longitude }\end{array}$ & $\begin{array}{l}\text { Dam/river } \\
\text { or stream }\end{array}$ & $\begin{array}{c}\text { Dam type/ } \\
\text { purpose }\end{array}$ & $\begin{array}{l}\text { Year } \\
\text { constructed/ } \\
\text { owner }\end{array}$ & $\begin{array}{l}\text { Height/ } \\
\text { length } \\
\text { (m) }\end{array}$ & $\begin{array}{l}\text { Storage } \\
\text { volume } \\
\left(\mathrm{Mm}^{3}\right)\end{array}$ & $\begin{array}{l}\text { Landslide } \\
\text { type }\end{array}$ & $\begin{array}{l}\text { Landslide } \\
\text { position } \\
\text { relative to } \\
\text { dam }\end{array}$ & Comments & $\begin{array}{l}\text { References/ } \\
\text { sources } \\
\text { of } \\
\text { information }\end{array}$ \\
\hline $\begin{array}{l}\text { United States/ } \\
\text { New York/ } \\
42.15 \mathrm{~N}, 79.01 \mathrm{~W}\end{array}$ & $\begin{array}{l}\text { Site 19/ } \\
\text { Battle Creek }\end{array}$ & $\begin{array}{l}\text { Earthfill/ } \\
\text { Flood control }\end{array}$ & $\begin{array}{l}\text { 1971/Local } \\
\text { government }\end{array}$ & $20 / 146$ & 0.48 & $\begin{array}{l}\text { Slump in } \\
\text { sedimen- } \\
\text { tary rocks }\end{array}$ & $\begin{array}{l}\text { Lower left } \\
\text { abutment }\end{array}$ & $\begin{array}{l}\text { Ancient slump in shale/siltstone was not recog- } \\
\text { nized during construction. Because of danger- } \\
\text { ous seepage, dam was breached in 1980. Further } \\
\text { exploration found slump underlain by alluvium. } \\
\text { Dam was redesigned and rebuilt in 1981. Remedial } \\
\text { measures installed: (1) cutoff trench deepened to } \\
\text { bedrock, (2) cutoff trench into embankment, and } \\
\text { (3) enlargement of foundation drainage system. } \\
\text { Failure to recognize landslide in abutment resulted } \\
\text { in substantial economic loss. }\end{array}$ & $\begin{array}{l}\text { Kirkaldie and } \\
\text { Thomas (1984), } \\
\text { Agnew (1985), } \\
\text { Kiersch and James } \\
\text { (1991)/None }\end{array}$ \\
\hline $\begin{array}{l}\text { United States/ } \\
\text { North Dakota/ } \\
48.46 \mathrm{~N}, 101.58 \mathrm{~W}\end{array}$ & $\begin{array}{l}\text { Lake Darling/ } \\
\text { Souris River }\end{array}$ & $\begin{array}{l}\text { Earthfill/ } \\
\text { Recreation, } \\
\text { fish and wild- } \\
\text { life }\end{array}$ & $\begin{array}{l}\text { 1936/Federal } \\
\text { government }\end{array}$ & $\begin{array}{l}12 / \\
1,006\end{array}$ & 280 & $\begin{array}{l}\text { Slumps in } \\
\text { clay till }\end{array}$ & $\begin{array}{l}\text { Both } \\
\text { abutments }\end{array}$ & $\begin{array}{l}\text { Slumps in both valley walls (age: } \sim 11,000 \mathrm{yr} \text { B.P.). } \\
\text { No movement in past } 10,000 \mathrm{yr} \text {. Toes of slumps re- } \\
\text { moved by post-slide erosion along floor of Souris } \\
\text { River valley. Slides cause no problems to dam. }\end{array}$ & $\begin{array}{l}\text { Lemke (1960, } \\
\text { p. } 96 \text {, plate 12), } \\
\text { Kehew (1983)/U.S. } \\
\text { Bureau of Rec- } \\
\text { lamation report; } \\
\text { consultant's report }\end{array}$ \\
\hline $\begin{array}{l}\text { United States/ } \\
\text { Oregon/ } \\
42.42 \mathrm{~N}, 122.78 \mathrm{~W}\end{array}$ & $\begin{array}{l}\text { Agate/ } \\
\text { Dry Creek }\end{array}$ & $\begin{array}{l}\text { Rockfill and } \\
\text { earthfill/ } \\
\text { Irrigation, } \\
\text { recreation }\end{array}$ & $\begin{array}{l}\text { 1966/Federal } \\
\text { government }\end{array}$ & $\begin{array}{l}26 / \\
1,158\end{array}$ & 7.02 & $\begin{array}{l}\text { Shallow } \\
\text { slump }\end{array}$ & $\begin{array}{l}\text { Left } \\
\text { abutment }\end{array}$ & $\begin{array}{l}\text { Shallow landslide in volcanic rocks occurred at left } \\
\text { abutment during construction; debris was removed } \\
\text { and slope of excavation flattened. Slump moved } \\
\text { again in early 1980s; toe was then excavated and } \\
\text { rockfill placed as buttress. Dam is now stable. }\end{array}$ & $\begin{array}{l}\text { Lockhart (1998)/ } \\
\text { U.S. Bureau of } \\
\text { Reclamation }\end{array}$ \\
\hline $\begin{array}{l}\text { United States/ } \\
\text { Oregon/ } \\
45.46 \mathrm{~N}, 121.85 \mathrm{~W}\end{array}$ & $\begin{array}{l}\text { Bull Run } \\
\text { Lake/Bull } \\
\text { Run River }\end{array}$ & $\begin{array}{l}\text { Concrete grav- } \\
\text { ity/ } \\
\text { Water supply }\end{array}$ & $\begin{array}{l}\text { 1965/City } \\
\text { government }\end{array}$ & $17 / 46$ & 17.9 & $\begin{array}{l}\text { Massive } \\
\text { landslide } \\
\text { (vol. } \sim 110 \\
\text { million } \mathrm{m}^{3} \text { ) }\end{array}$ & $\begin{array}{l}\text { Entire } \\
\text { dam on } \\
\text { landslide }\end{array}$ & $\begin{array}{l}\text { Dam constructed on prehistoric landslide dam } \\
\text { about } 70 \text { m thick. Considerable seepage emerges } \\
\text { from landslide dam material downstream of dam. } \\
\text { About } 60 \text { percent of flow in Bull Run River down- } \\
\text { stream comes from these springs. }\end{array}$ & $\begin{array}{l}\text { Schulz (1980), } \\
\text { Snyder and } \\
\text { Brownell (1996)/ } \\
\text { City of Portland }\end{array}$ \\
\hline
\end{tabular}


Appendix table A. Dam characteristics, relation to landslides, mitigative measures, and cited references-Continued.

\begin{tabular}{|c|c|c|c|c|c|c|c|c|c|}
\hline $\begin{array}{l}\text { Country/ } \\
\text { state } \\
\text { or province/ } \\
\text { latitude, } \\
\text { longitude }\end{array}$ & $\begin{array}{l}\text { Dam/river } \\
\text { or stream }\end{array}$ & $\begin{array}{l}\text { Dam type/ } \\
\text { purpose }\end{array}$ & $\begin{array}{c}\text { Year } \\
\text { constructed/ } \\
\text { owner }\end{array}$ & $\begin{array}{l}\text { Height/ } \\
\text { length } \\
\text { (m) }\end{array}$ & $\begin{array}{c}\text { Storage } \\
\text { volume } \\
\left(\mathrm{Mm}^{3}\right)\end{array}$ & $\begin{array}{l}\text { Landslide } \\
\text { type }\end{array}$ & $\begin{array}{l}\text { Landslide } \\
\text { position } \\
\text { relative to } \\
\text { dam }\end{array}$ & Comments & $\begin{array}{l}\text { References/ } \\
\text { sources } \\
\text { of } \\
\text { information }\end{array}$ \\
\hline $\begin{array}{l}\text { United States/ } \\
\text { Oregon/ } \\
45.50 \mathrm{~N}, 122.10 \mathrm{~W}\end{array}$ & $\begin{array}{l}\text { Bull Run No. } \\
\text { 2/Bull Run } \\
\text { River }\end{array}$ & $\begin{array}{l}\text { Rockfill/ } \\
\text { Hydroelectric, } \\
\text { water supply }\end{array}$ & $\begin{array}{l}\text { 1962/City } \\
\text { government }\end{array}$ & $44 / 275$ & 30.8 & $\begin{array}{l}\text { Rock } \\
\text { slide: } \\
\text { andesite } \\
\text { and basalt } \\
\text { over soft } \\
\text { volcanics }\end{array}$ & $\begin{array}{l}\text { Both } \\
\text { abutments }\end{array}$ & $\begin{array}{l}\text { Valley floor in basalt; both abutments are sta- } \\
\text { tionary slide debris consisting of andesite/basalt } \\
\text { rubble in matrix of clay, silt, and sand. Following } \\
\text { construction, occurrence of springs downstream } \\
\text { from dam resulted in installation of extensive grout } \\
\text { curtain. Some seepage continues. }\end{array}$ & $\begin{array}{l}\text { Beaulieu (1974), } \\
\text { Schulz (1980), } \\
\text { Hammond and } \\
\text { Griffiths (1998), } \\
\text { Mohammadi and } \\
\text { others (2000)/ } \\
\text { U.S. Army } \\
\text { Corps of } \\
\text { Engineers; City } \\
\text { of Portland }\end{array}$ \\
\hline $\begin{array}{l}\text { United States/ } \\
\text { Oregon/ } \\
44.24 \mathrm{~N}, 118.78 \mathrm{~W}\end{array}$ & $\begin{array}{l}\text { Canyon Creek } \\
\text { Meadows/ } \\
\text { Canyon Creek }\end{array}$ & $\begin{array}{l}\text { Earthfill/ } \\
\text { Recreation }\end{array}$ & $\begin{array}{l}\text { 1963/State } \\
\text { government }\end{array}$ & $18 / 53$ & 0.49 & Rock slide & $\begin{array}{l}\text { Left abutment } \\
\text { and part of } \\
\text { right abut- } \\
\text { ment }\end{array}$ & $\begin{array}{l}\text { Left abutment and part of right abutment are } \\
\text { remnants of large rhyolitic rock slide that formerly } \\
\text { blocked stream channel. Seepage through left abut- } \\
\text { ment. When visited in 1998, reservoir was empty } \\
\text { and dam was not functioning. }\end{array}$ & $\begin{array}{l}\text { Holdredge } \\
\text { (1957)/Oregon } \\
\text { Department of } \\
\text { Water Resources; } \\
\text { Oregon Depart- } \\
\text { ment of Fish and } \\
\text { Wildlife; U.S. } \\
\text { Forest Service; } \\
\text { U.S. Army Corps } \\
\text { of Engineers }\end{array}$ \\
\hline $\begin{array}{l}\text { United States/ } \\
\text { Oregon/ } \\
45.52 \mathrm{~N}, 122.71 \mathrm{~W}\end{array}$ & $\begin{array}{l}\text { City of Port- } \\
\text { land Dam No. } \\
\text { 3/Bull Run } \\
\text { River }\end{array}$ & $\begin{array}{l}\text { Concrete } \\
\text { gravity/ } \\
\text { Water supply }\end{array}$ & $\begin{array}{l}\text { 1894/City } \\
\text { government }\end{array}$ & $16 / 30$ & 0.06 & $\begin{array}{l}\text { "Ancient" } \\
\text { landslide } \\
\text { in basalt } \\
\text { and clay }\end{array}$ & $\begin{array}{l}\text { Foundation } \\
\text { and right } \\
\text { abutment }\end{array}$ & $\begin{array}{l}\text { Movement in "phenomenal landslide" (volume: } \\
\text { 2.6 million } \mathrm{m}^{3} \text { ) noted during construction (Clarke, } \\
\text { 1904). From 1895-1903: drainage tunnels in- } \\
\text { stalled; 1904-76: reservoir linings rebuilt. In 1977, } \\
\text { flexible membrane liner installed. }\end{array}$ & $\begin{array}{l}\text { Clarke }(1904) / \\
\text { Oregon Depart- } \\
\text { ment of Water } \\
\text { Resources; con- } \\
\text { sultants' reports }\end{array}$ \\
\hline $\begin{array}{l}\text { United States/ } \\
\text { Oregon/ } \\
42.71 \mathrm{~N}, 122.74 \mathrm{~W}\end{array}$ & $\begin{array}{l}\text { Elk Creek/ } \\
\text { Elk Creek }\end{array}$ & $\begin{array}{l}\text { Roller- } \\
\text { compacted } \\
\text { concrete } \\
(\mathrm{RCC}) / \text { Flood } \\
\text { control, } \\
\text { irrigation }\end{array}$ & $\begin{array}{l}\text { Environmen- } \\
\text { tal concerns } \\
\text { halted con- } \\
\text { struction in } \\
\text { 1986/Federal } \\
\text { government }\end{array}$ & $\begin{array}{l}\text { Planned: } \\
76 / 786\end{array}$ & 125 & $\begin{array}{l}\text { Rock slide } \\
\text { (volcanic } \\
\text { rocks) }\end{array}$ & $\begin{array}{l}\text { Right } \\
\text { abutment }\end{array}$ & $\begin{array}{l}\text { During construction, three low-angle "shear zones" } \\
\text { noted in right abutment. Excavation caused } 7 \mathrm{~cm} \\
\text { of movement before concrete-filled key trench was } \\
\text { installed to buttress sliding mass. Dam was half } \\
\text { completed when project was terminated for envi- } \\
\text { ronmental reasons (not because of slide problems). }\end{array}$ & $\begin{array}{l}\text { Amundson and } \\
\text { Scofield (1998)/ } \\
\text { U.S. Army } \\
\text { Corps of } \\
\text { Engineers; con- } \\
\text { sultant's report }\end{array}$ \\
\hline
\end{tabular}


Appendix table A. Dam characteristics, relation to landslides, mitigative measures, and cited references-Continued.

\begin{tabular}{|c|c|c|c|c|c|c|c|c|c|}
\hline $\begin{array}{l}\text { Country/ } \\
\text { state } \\
\text { or province } \\
\text { /latitude, } \\
\text { longitude }\end{array}$ & $\begin{array}{l}\text { Dam/river } \\
\text { or stream }\end{array}$ & $\begin{array}{l}\text { Dam type/ } \\
\text { purpose }\end{array}$ & $\begin{array}{c}\text { Year } \\
\text { constructed/ } \\
\text { owner }\end{array}$ & $\begin{array}{l}\text { Height/ } \\
\text { length } \\
\text { (m) }\end{array}$ & $\begin{array}{c}\text { Storage } \\
\text { volume } \\
\left(\mathrm{Mm}^{3}\right)\end{array}$ & $\begin{array}{l}\text { Landslide } \\
\text { type }\end{array}$ & $\begin{array}{l}\text { Landslide } \\
\text { position } \\
\text { relative to } \\
\text { dam }\end{array}$ & Comments & $\begin{array}{l}\text { References/ } \\
\text { sources } \\
\text { of } \\
\text { information }\end{array}$ \\
\hline $\begin{array}{l}\text { United States/ } \\
\text { Oregon/ } \\
42.17 \mathrm{~N}, 122.60 \mathrm{~W}\end{array}$ & $\begin{array}{l}\text { Emigrant/ } \\
\text { Emigrant } \\
\text { Creek }\end{array}$ & $\begin{array}{l}\text { Earthfill-rock- } \\
\text { fill, concrete/ } \\
\text { Irrigation, } \\
\text { recreation, } \\
\text { flood control }\end{array}$ & $\begin{array}{l}\text { 1924/Federal } \\
\text { government }\end{array}$ & $62 / 229$ & 57.6 & Rock slide & $\begin{array}{l}\text { Right } \\
\text { abutment }\end{array}$ & $\begin{array}{l}\text { Pre-existing slide in sandstone, siltstone, and shale } \\
\text { reactivated during construction; minor movement } \\
\text { since. Most of slide is on right shore immediately } \\
\text { upstream from dam. Mass appears fairly stable at } \\
\text { present; dam is in no danger. }\end{array}$ & $\begin{array}{l}\text { Hammond and } \\
\text { Griffiths (1998)/ } \\
\text { U.S. Bureau of } \\
\text { Reclamation }\end{array}$ \\
\hline $\begin{array}{l}\text { United States/ } \\
\text { Oregon/ } \\
45.09 \mathrm{~N}, 122.05 \mathrm{~W}\end{array}$ & $\begin{array}{l}\text { Frog Lake/ } \\
\text { Oak Grove } \\
\text { Fork, } \\
\text { Clackamas } \\
\text { River }\end{array}$ & $\begin{array}{l}\text { Earthfill/ } \\
\text { Hydroelectric }\end{array}$ & $\begin{array}{l}\text { 1955/Private } \\
\text { power } \\
\text { company }\end{array}$ & $15 / 738$ & 0.65 & $\begin{array}{l}\text { Huge an- } \\
\text { cient rock } \\
\text { slide }(\text { area } \\
\left.\sim 50 \mathrm{~km}^{2}\right)\end{array}$ & $\begin{array}{l}\text { Entire dam } \\
\text { and reser- } \\
\text { voir }\end{array}$ & $\begin{array}{l}\text { Seepage and cracking of reservoir bottom were a } \\
\text { continuing maintenance problem for this dam. In } \\
\text { 1991, it was recognized that Frog Lake Dam is lo- } \\
\text { cated on the reactivated part of a } 50-\mathrm{km}^{2} \text { landslide } \\
\text { (basalt and andesite rubble in tuff breccia). Dam } \\
\text { was rebuilt in } 1998 \text {. }\end{array}$ & $\begin{array}{l}\text { Hammond (1999, } \\
\text { Cornforth and } \\
\text { Mikkelsen (2000)/ } \\
\text { Federal Energy } \\
\text { Regulatory Com- } \\
\text { mission; U.S. Forest } \\
\text { Service; Oregon } \\
\text { Department of } \\
\text { Water Resources; } \\
\text { consultants' reports; } \\
\text { company report }\end{array}$ \\
\hline $\begin{array}{l}\text { United States/ } \\
\text { Oregon/ } \\
42.13 \mathrm{~N}, 122.47 \mathrm{~W}\end{array}$ & $\begin{array}{l}\text { Keene Creek/ } \\
\text { Keene Creek }\end{array}$ & $\begin{array}{l}\text { Rock-faced } \\
\text { earthfill/ } \\
\text { Hydroelectric, } \\
\text { irrigation }\end{array}$ & $\begin{array}{l}\text { 1959/Federal } \\
\text { government }\end{array}$ & $25 / 170$ & 0.48 & $\begin{array}{l}\text { Rotational } \\
\text { earth } \\
\text { slump }\end{array}$ & $\begin{array}{l}\text { Right } \\
\text { abutment }\end{array}$ & $\begin{array}{l}\text { Slump is chaotic mixture of weathered rock frag- } \\
\text { ments, sand, silt, and clay. Slump recognized prior } \\
\text { to construction, resulting in moving spillway from } \\
\text { right to left end. Abutment is stable, but produces } \\
\text { some seepage. }\end{array}$ & $\begin{array}{l}\text { None/U.S. Bureau } \\
\text { of Reclamation; } \\
\text { consultants' reports }\end{array}$ \\
\hline $\begin{array}{l}\text { United States/ } \\
\text { Oregon/ } \\
45.08 \mathrm{~N}, 121.96 \mathrm{~W}\end{array}$ & $\begin{array}{l}\text { Lake Harriet/ } \\
\text { Oak Grove } \\
\text { Creek }\end{array}$ & $\begin{array}{l}\text { Concrete arch } \\
\text { buttressed with } \\
\text { rockfill/ } \\
\text { Hydroelectric }\end{array}$ & $\begin{array}{l}\text { 1923/Private } \\
\text { power com- } \\
\text { pany }\end{array}$ & $21 / 57$ & 0.49 & $\begin{array}{l}\text { Edge of } \\
\text { huge rock } \\
\text { slide }\end{array}$ & $\begin{array}{l}\text { Left } \\
\text { abutment }\end{array}$ & $\begin{array}{l}\text { Left abutment (basalt) is toe of huge landslide } \\
\text { noted above for Frog Lake Dam. Slide has been } \\
\text { moving toward dam, causing cracking of arch. } \\
\text { Remedial measures installed in 1985: (1) impervi- } \\
\text { ous bentonitic membrane placed against upstream } \\
\text { dam face by means of a tremie pipe and (2) rock- } \\
\text { fill buttresses against both dam faces. }\end{array}$ & $\begin{array}{l}\text { Schroeder and } \\
\text { others (1988)/Or- } \\
\text { egon Department } \\
\text { of Water Resources; } \\
\text { consultants' reports }\end{array}$ \\
\hline
\end{tabular}


Appendix table A. Dam characteristics, relation to landslides, mitigative measures, and cited references-Continued.

\begin{tabular}{|c|c|c|c|c|c|c|c|c|c|}
\hline $\begin{array}{l}\text { Country/ } \\
\text { state } \\
\text { or province/ } \\
\text { latitude, } \\
\text { longitude }\end{array}$ & $\begin{array}{l}\text { Dam/river } \\
\text { or stream }\end{array}$ & $\begin{array}{l}\text { Dam type/ } \\
\text { purpose }\end{array}$ & $\begin{array}{c}\text { Year } \\
\text { constructed/ } \\
\text { owner }\end{array}$ & $\begin{array}{c}\text { Height/ } \\
\text { length } \\
\text { (m) }\end{array}$ & $\begin{array}{c}\text { Storage } \\
\text { volume } \\
\left(\mathrm{Mm}^{3}\right)\end{array}$ & $\begin{array}{l}\text { Landslide } \\
\text { type }\end{array}$ & $\begin{array}{l}\text { Landslide } \\
\text { position } \\
\text { relative to } \\
\text { dam }\end{array}$ & Comments & $\begin{array}{l}\text { References/ } \\
\text { sources } \\
\text { of } \\
\text { information }\end{array}$ \\
\hline $\begin{array}{l}\text { United States/ } \\
\text { Oregon/ } \\
43.91 \mathrm{~N}, 122.75 \mathrm{~W}\end{array}$ & $\begin{array}{l}\text { Lookout } \\
\text { Point/Middle } \\
\text { Fork } \\
\text { Willamette } \\
\text { River }\end{array}$ & $\begin{array}{l}\text { Earthfill/ } \\
\text { Flood control, } \\
\text { irrigation, } \\
\text { navigation, } \\
\text { hydroelectric, } \\
\text { recreation }\end{array}$ & $\begin{array}{l}\text { 1953/Federal } \\
\text { government }\end{array}$ & $84 / 462$ & 589 & $\begin{array}{l}\text { Slides in } \\
\text { volca- } \\
\text { nic tuff } \\
\text { altered to } \\
\text { clay; talus }\end{array}$ & $\begin{array}{l}\text { Right } \\
\text { abutment }\end{array}$ & $\begin{array}{l}\text { Remnants of clay/talus deposit on both sides of } \\
\text { valley. Right end of core trench was excavated } \\
\text { through pre-existing large slide, resulting in re- } \\
\text { activation upstream of trench. New slide deposit } \\
\text { was removed, but pre-existing slide material } \\
\text { downstream from core trench apparently remains } \\
\text { in place and is stable. }\end{array}$ & $\begin{array}{l}\text { Howell (1952), } \\
\text { Staples (1964)/U.S. } \\
\text { Army Corps of } \\
\text { Engineers report }\end{array}$ \\
\hline $\begin{array}{l}\text { United States/ } \\
\text { Oregon/ } \\
44.30 \mathrm{~N}, 120.73 \mathrm{~W}\end{array}$ & $\begin{array}{l}\text { Ochoco/ } \\
\text { Ochoco Creek }\end{array}$ & $\begin{array}{l}\text { Earthfill (hy- } \\
\text { draulic fill)/ } \\
\text { Irrigation }\end{array}$ & $\begin{array}{l}\text { 1920/Private } \\
\text { irrigation } \\
\text { district }\end{array}$ & $38 / 411$ & 57.3 & $\begin{array}{l}\text { Large rock } \\
\text { slide-- } \\
\text { lateral } \\
\text { spread }\end{array}$ & $\begin{array}{l}\text { Right } \\
\text { abutment }\end{array}$ & $\begin{array}{l}\text { Late Pleistocene landslide forming right abut- } \\
\text { ment probably was caused by plastic flow of } \\
\text { bentonitic zones in dacitic tuff and claystone. Site } \\
\text { was probably chosen because of landslide-caused } \\
\text { valley constriction. Seepage through right abut- } \\
\text { ment has been continuing problem. Modification } \\
\text { during 1990s: deep interceptor trench with zone } \\
\text { of impervious material reduces seepage. }\end{array}$ & $\begin{array}{l}\text { Mumford (1994), } \\
\text { Carter (1998a,b), } \\
\text { Kunzer (1998)/U.S. } \\
\text { Bureau of } \\
\text { Reclamation }\end{array}$ \\
\hline $\begin{array}{l}\text { United States/ } \\
\text { Oregon/ } \\
44.72 \mathrm{~N}, 121.25 \mathrm{~W}\end{array}$ & $\begin{array}{l}\text { Pelton } \\
\text { Regulating } \\
\text { Dam/ } \\
\text { Deschutes } \\
\text { River }\end{array}$ & $\begin{array}{l}\text { Concrete } \\
\text { gravity/ } \\
\text { Hydroelectric, } \\
\text { flood control }\end{array}$ & $\begin{array}{l}\text { 1950/Private } \\
\text { power com- } \\
\text { pany }\end{array}$ & $12 / 325$ & 4.32 & $\begin{array}{l}\text { Transla- } \\
\text { tional/ } \\
\text { rotational } \\
\text { rock slide } \\
\text { in volca- } \\
\text { nic tuff }\end{array}$ & $\begin{array}{l}\text { Left } \\
\text { abutment }\end{array}$ & $\begin{array}{l}\text { "The left abutment of the regulating dam was } \\
\text { constructed on the toe of this extensive ancient } \\
\text { landslide" (Benson and Pate, 1998). No prob- } \\
\text { lems. }\end{array}$ & $\begin{array}{l}\text { Kent (1981), Benson } \\
\text { and Pate (1998)/None }\end{array}$ \\
\hline $\begin{array}{l}\text { United States/ } \\
\text { Oregon/ } \\
45.95 \mathrm{~N}, 123.92 \mathrm{~W}\end{array}$ & $\begin{array}{l}\text { Peterson } \\
\text { Point/South } \\
\text { Fork } \\
\text { Necanicum } \\
\text { River }\end{array}$ & $\begin{array}{l}\text { Earthfill/ } \\
\text { Water supply }\end{array}$ & $\begin{array}{l}\text { 1954/Local } \\
\text { government }\end{array}$ & $14 / 79$ & 0.21 & $\begin{array}{l}\text { Slides in } \\
\text { mudstone }\end{array}$ & $\begin{array}{l}\text { Both } \\
\text { abutments }\end{array}$ & $\begin{array}{l}\text { There has been no movement of abutment slides } \\
\text { since construction. Dam was raised to 14-m } \\
\text { height in 1996. No problems. }\end{array}$ & $\begin{array}{l}\text { None/Oregon Depart- } \\
\text { ment of Water } \\
\text { Resources; } \\
\text { consultants' } \\
\text { reports }\end{array}$ \\
\hline
\end{tabular}


Appendix table A. Dam characteristics, relation to landslides, mitigative measures, and cited references-Continued.

\begin{tabular}{|c|c|c|c|c|c|c|c|c|c|}
\hline $\begin{array}{l}\text { Country/ } \\
\text { state } \\
\text { or province/ } \\
\text { latitude, } \\
\text { longitude }\end{array}$ & $\begin{array}{l}\text { Dam/river } \\
\text { or stream }\end{array}$ & $\begin{array}{l}\text { Dam type/ } \\
\text { purpose }\end{array}$ & $\begin{array}{c}\text { Year } \\
\text { constructed/ } \\
\text { owner }\end{array}$ & $\begin{array}{l}\text { Height/ } \\
\text { length } \\
\text { (m) }\end{array}$ & $\begin{array}{c}\text { Storage } \\
\text { volume } \\
\left(\mathrm{Mm}^{3}\right)\end{array}$ & $\begin{array}{l}\text { Landslide } \\
\text { type }\end{array}$ & $\begin{array}{l}\text { Landslide } \\
\text { position } \\
\text { relative } \\
\text { to dam }\end{array}$ & Comments & $\begin{array}{l}\text { References/ } \\
\text { sources } \\
\text { of } \\
\text { information }\end{array}$ \\
\hline $\begin{array}{l}\text { United States/ } \\
\text { Oregon/ } \\
45.53 \mathrm{~N}, 122.99 \mathrm{~W}\end{array}$ & $\begin{array}{l}\text { Sams Valley/ } \\
\text { Sams Creek, } \\
\text { Zana Creek }\end{array}$ & $\begin{array}{l}\text { Earthfill/ } \\
\text { Irrigation }\end{array}$ & $\begin{array}{l}\text { 1956/Private } \\
\text { irrigation } \\
\text { district }\end{array}$ & $19 / 101$ & 1.48 & $\begin{array}{l}\text { Large } \\
\text { rotational } \\
\text { landslide }\end{array}$ & $\begin{array}{l}\text { Right } \\
\text { abutment }\end{array}$ & $\begin{array}{l}\text { Low ridge at right abutment and right shore of } \\
\text { reservoir apparently formed by large rotational } \\
\text { landslide in sandstone. Seepage occurs through } \\
\text { landslide mass. Stability and seepage satisfactory } \\
\text { under reduced reservoir filling dictated by State of } \\
\text { Oregon. }\end{array}$ & $\begin{array}{l}\text { None/Oregon } \\
\text { Department of } \\
\text { Water Resources }\end{array}$ \\
\hline $\begin{array}{l}\text { United States/ } \\
\text { Oregon/ } \\
45.49 \mathrm{~N}, 123.21 \mathrm{~W}\end{array}$ & $\begin{array}{l}\text { Scoggins/ } \\
\text { Scoggins } \\
\text { Creek }\end{array}$ & $\begin{array}{l}\text { Earthfill/ } \\
\text { Irrigation, } \\
\text { water supply }\end{array}$ & $\begin{array}{l}\text { 1975/Federal } \\
\text { government }\end{array}$ & $46 / 817$ & 77.1 & Earth slide & $\begin{array}{l}\text { Right } \\
\text { abutment }\end{array}$ & $\begin{array}{l}\text { Quaternary landslide in sandy silt and silty sand } \\
\text { forms right abutment. Monitoring program checks } \\
\text { for movement every } 3 \text { years; there has been none. }\end{array}$ & $\begin{array}{l}\text { None/U.S. Bureau } \\
\text { of Reclamation; } \\
\text { U.S. Geological } \\
\text { Survey }\end{array}$ \\
\hline $\begin{array}{l}\text { United States/ } \\
\text { Oregon/ } \\
45.37 \mathrm{~N}, 123.70 \mathrm{~W}\end{array}$ & $\begin{array}{l}\text { Skookum } \\
\text { Lake/Fawcett } \\
\text { Creek }\end{array}$ & $\begin{array}{l}\text { Earthfill/ } \\
\text { Water supply }\end{array}$ & $\begin{array}{l}\text { 1965/Public } \\
\text { utility }\end{array}$ & $13 / 192$ & 1.4 & $\begin{array}{l}\text { Debris } \\
\text { slide in } \\
\text { soil and } \\
\text { rock }\end{array}$ & $\begin{array}{l}\text { Right abut- } \\
\text { ment and } \\
\text { right } 100 \mathrm{~m} \\
\text { of } \\
\text { foundation }\end{array}$ & $\begin{array}{l}\text { Dam was built on "old" ( }>500 \text { yr B.P.) landslide } \\
\text { dam. A deep }(\sim 7 \mathrm{~m}) \text { core trench was excavated } \\
\text { through landslide deposit to reduce seepage. }\end{array}$ & $\begin{array}{l}\text { None/City of } \\
\text { Tillamook reports; } \\
\text { consultant's report; } \\
\text { R. Lindquist (writ- } \\
\text { ten commun., 1998) }\end{array}$ \\
\hline $\begin{array}{l}\text { United States/ } \\
\text { Oregon/ } \\
43.53 \mathrm{~N}, 118.08 \mathrm{~W}\end{array}$ & $\begin{array}{l}\text { Star Moun- } \\
\text { tain/ } \\
\text { Granite Creek }\end{array}$ & $\begin{array}{l}\text { Earthfill/ } \\
\text { Irrigation }\end{array}$ & 1961/Private & $21 / 87$ & 1.8 & $\begin{array}{l}\text { Large } \\
\text { slide in } \\
\text { siltstone } \\
\text { (tuff?) and } \\
\text { basalt }\end{array}$ & $\begin{array}{l}\text { Right } \\
\text { abutment }\end{array}$ & $\begin{array}{l}\text { Entire right bank of Granite Creek in vicinity of } \\
\text { dam and reservoir is located on toe of huge ancient } \\
\text { landslide. In 1983, original spillway (at right abut- } \\
\text { ment) was eroded out by floodwater. Right end of } \\
\text { dam rebuilt with circular concrete spillway passing } \\
\text { through embankment. }\end{array}$ & $\begin{array}{l}\text { Holton }(1983) / \\
\text { Oregon Department } \\
\text { of Water Resources; } \\
\text { consultants' reports }\end{array}$ \\
\hline $\begin{array}{l}\text { United States/ } \\
\text { Pennsylvania/ } \\
\text { 40.38N, 79.02W }\end{array}$ & $\begin{array}{l}\text { Sugar Run/ } \\
\text { Little Sugar } \\
\text { Run Creek }\end{array}$ & $\begin{array}{l}\text { Earthfill/ } \\
\text { Water supply }\end{array}$ & $\begin{array}{l}\text { 1907/Water } \\
\text { utility com- } \\
\text { pany }\end{array}$ & $18 / 274$ & 0.58 & Rock slide & $\begin{array}{l}\text { Right } \\
\text { abutment }\end{array}$ & $\begin{array}{l}\text { Prehistoric rock slide (sandstone, siltstone, and } \\
\text { shale) forms right abutment. Dam has long his- } \\
\text { tory of foundation/abutment leakage. Flood in } \\
\text { 1990s caused minor reactivation of right-abutment } \\
\text { landslide. }\end{array}$ & $\begin{array}{l}\text { None/Consultants' } \\
\text { reports }\end{array}$ \\
\hline
\end{tabular}


Appendix table A. Dam characteristics, relation to landslides, mitigative measures, and cited references-Continued.

\begin{tabular}{|c|c|c|c|c|c|c|c|c|c|}
\hline $\begin{array}{c}\text { Country/ } \\
\text { state } \\
\text { or province } \\
\text { /latitude, } \\
\text { longitude }\end{array}$ & $\begin{array}{l}\text { Dam/river } \\
\text { or stream }\end{array}$ & $\begin{array}{c}\text { Dam type/ } \\
\text { purpose }\end{array}$ & $\begin{array}{c}\text { Year } \\
\text { constructed/ } \\
\text { owner }\end{array}$ & $\begin{array}{c}\text { Height/ } \\
\text { length } \\
\text { (m) }\end{array}$ & $\begin{array}{c}\text { Storage } \\
\text { volume } \\
\left(\mathrm{Mm}^{3}\right)\end{array}$ & $\begin{array}{l}\text { Landslide } \\
\text { type }\end{array}$ & $\begin{array}{l}\text { Landslide } \\
\text { position } \\
\text { relative to } \\
\text { dam }\end{array}$ & Comments & $\begin{array}{c}\text { References/ } \\
\text { sources } \\
\text { of } \\
\text { information }\end{array}$ \\
\hline $\begin{array}{l}\text { United States/ } \\
\text { South Dakota/ } \\
44.45 \mathrm{~N}, 100.39 \mathrm{~W}\end{array}$ & $\begin{array}{l}\text { Oahe/ } \\
\text { Missouri } \\
\text { River }\end{array}$ & $\begin{array}{l}\text { Earthfill/ } \\
\text { Flood control, } \\
\text { hydroelectric, } \\
\text { irrigation, } \\
\text { navigation, } \\
\text { recreation }\end{array}$ & $\begin{array}{l}\text { 1966/Federal } \\
\text { government }\end{array}$ & $\begin{array}{l}75 / \\
2,835\end{array}$ & 29,000 & $\begin{array}{l}\text { Rotational } \\
\text { slides in } \\
\text { shale }\end{array}$ & $\begin{array}{l}\text { Remnant of } \\
\text { small slide } \\
\text { in right } \\
\text { abutment; } \\
\text { construction } \\
\text { slide in left } \\
\text { abutment }\end{array}$ & $\begin{array}{l}\text { Pre-existing slides in shale originally formed } \\
\text { much of right abutment. Slide occurred in left } \\
\text { abutment during construction; } 5.0 \text { million } \mathrm{m}^{3} \\
\text { was removed ( } 3.5 \text { million } \mathrm{m}^{3} \text { used as buttress). } \\
\text { Probably some remains beneath embankment. } \\
\text { Part of small slide remains in right abutment. } \\
\text { Both abutments are buttressed by weight of } \\
\text { dam. No stability problems. }\end{array}$ & $\begin{array}{l}\text { Crandell (1951, } \\
\text { 1952, 1958, } \\
\text { p. 72-77), } \\
\text { Engineering } \\
\text { Division (1958), } \\
\text { Knight (1963)/ } \\
\text { D.R. Crandell } \\
\text { (U.S. Geological } \\
\text { Survey, oral com- } \\
\text { mun., 1997) }\end{array}$ \\
\hline
\end{tabular}

\begin{tabular}{|c|c|c|c|c|c|c|c|c|c|}
\hline $\begin{array}{l}\text { United States/ } \\
\text { Texas/ } \\
97.22 \mathrm{~N}, 31.60 \mathrm{~W}\end{array}$ & $\begin{array}{l}\text { Waco/ } \\
\text { Bosque River }\end{array}$ & $\begin{array}{l}\text { Earthfill/ } \\
\text { Water supply, } \\
\text { flood control }\end{array}$ & $\begin{array}{l}\text { 1965/Federal } \\
\text { government }\end{array}$ & $\begin{array}{l}42 / \\
5,464\end{array}$ & 1,021 & $\begin{array}{l}\text { Basal } \\
\text { slide in } \\
\text { Pepper } \\
\text { Shale }\end{array}$ & Foundation & $\begin{array}{l}\text { Slide in Pepper Shale foundation occurred dur- } \\
\text { ing construction (1961); embankment was } 93 \\
\text { percent completed. Slide in embankment was a } \\
\text { slump; translational in foundation shale. Length } \\
\text { of slide: } 500 \mathrm{~m} \text {. Remedial measures: (1) em- } \\
\text { bankment slopes extended at flatter slopes than } \\
\text { original and (2) berm placed at lower toe. }\end{array}$ & $\begin{array}{l}\text { Beene (1967), } \\
\text { Stroman and } \\
\text { others (1984)/ } \\
\text { None }\end{array}$ \\
\hline
\end{tabular}

\begin{tabular}{|c|c|c|c|c|c|c|c|c|c|}
\hline $\begin{array}{l}\text { United States/ } \\
\text { Utah/ } \\
40.87 \mathrm{~N}, 111.03 \mathrm{~W}\end{array}$ & $\begin{array}{l}\text { Boyer Lake/ } \\
\text { Chalk Creek }\end{array}$ & $\begin{array}{l}\text { Earthfill/ } \\
\text { Irrigation }\end{array}$ & 1939/Private & $14 / 396$ & 0.01 & $\begin{array}{l}\text { Large } \\
\text { landslide } \\
\text { complex }\end{array}$ & Entire dam & $\begin{array}{l}\text { Dam and reservoir entirely within large }(\sim 50 \\
\left.\mathrm{km}^{2}\right) \text { landslide area. No problems have been } \\
\text { reported. }\end{array}$ & $\begin{array}{l}\text { Bryant (1990)/ } \\
\text { None }\end{array}$ \\
\hline $\begin{array}{l}\text { United States/ } \\
\text { Utah/ } \\
40.73 \mathrm{~N}, 109.21 \mathrm{~W}\end{array}$ & $\begin{array}{l}\text { Calder/ } \\
\text { Pot Creek }\end{array}$ & $\begin{array}{l}\text { Earthfill/ } \\
\text { Irrigation }\end{array}$ & $\begin{array}{l}\text { 1989/State } \\
\text { government }\end{array}$ & $15 / 114$ & 2.8 & $\begin{array}{l}\text { Block } \\
\text { slide in } \\
\text { Precam- } \\
\text { brian } \\
\text { sandstone }\end{array}$ & $\begin{array}{l}\text { Left } \\
\text { abutment }\end{array}$ & $\begin{array}{l}\text { Small sandstone and shale bedding-plane block } \\
\text { slide noted before construction. Cement grout } \\
\text { curtain added to successfully prevent seepage. } \\
\text { Slide buttressed by dam. }\end{array}$ & $\begin{array}{l}\text { Everitt and Schus- } \\
\text { ter (1999)/Utah } \\
\text { Division of Water } \\
\text { Resources }\end{array}$ \\
\hline $\begin{array}{l}\text { United States/ } \\
\text { Utah/ } \\
40.72 \mathrm{~N}, 109.17 \mathrm{~W}\end{array}$ & $\begin{array}{l}\text { Crouse/Pot } \\
\text { Creek }\end{array}$ & $\begin{array}{l}\text { Earthfill/Rec- } \\
\text { reation, fish } \\
\text { and wildlife }\end{array}$ & $\begin{array}{l}\text { 1952/State } \\
\text { government }\end{array}$ & $11 / 306$ & 1.34 & $\begin{array}{l}\text { Small } \\
\text { block } \\
\text { slide in } \\
\text { sandstone/ } \\
\text { shale }\end{array}$ & $\begin{array}{l}\text { Left } \\
\text { abutment }\end{array}$ & $\begin{array}{l}\text { "Ancient" rock-block movement of sandstone } \\
\text { blocks that form left abutment. Seepage prob- } \\
\text { lems occurred through the slide. Repairs were } \\
\text { made while reservoir was drawn down. Reser- } \\
\text { voir was refilled in } 1992 \text {. }\end{array}$ & $\begin{array}{l}\text { Everitt and Schus- } \\
\text { ter (1999)/Consul- } \\
\text { tant's report; Utah } \\
\text { Division of Water } \\
\text { Resources }\end{array}$ \\
\hline
\end{tabular}


Appendix table A. Dam characteristics, relation to landslides, mitigative measures, and cited references—Continued.

\begin{tabular}{|c|c|c|c|c|c|c|c|c|c|}
\hline $\begin{array}{c}\text { Country/ } \\
\text { state } \\
\text { or province/ } \\
\text { latitude, } \\
\text { longitude }\end{array}$ & $\begin{array}{l}\text { Dam/river } \\
\text { or stream }\end{array}$ & $\begin{array}{l}\text { Dam type/ } \\
\text { purpose }\end{array}$ & $\begin{array}{c}\text { Year } \\
\text { constructed/ } \\
\text { owner }\end{array}$ & $\begin{array}{l}\text { Height/ } \\
\text { length } \\
\text { (m) }\end{array}$ & $\begin{array}{c}\text { Storage } \\
\text { volume } \\
\left(\mathrm{Mm}^{3}\right)\end{array}$ & $\begin{array}{l}\text { Landslide } \\
\text { type }\end{array}$ & $\begin{array}{l}\text { Landslide } \\
\text { position } \\
\text { relative to } \\
\text { dam }\end{array}$ & Comments & $\begin{array}{l}\text { References/ } \\
\text { sources } \\
\text { of } \\
\text { information }\end{array}$ \\
\hline $\begin{array}{l}\text { United States/ } \\
\text { Utah/ } \\
39.62 \mathrm{~N}, 110.39 \mathrm{~W}\end{array}$ & $\begin{array}{l}\text { Grassy Trail/ } \\
\text { Whitmore } \\
\text { Canyon Creek }\end{array}$ & $\begin{array}{l}\text { Earthfill/ } \\
\text { Water supply }\end{array}$ & 1952/Private & $27 / 183$ & 1.4 & $\begin{array}{l}\text { Earth-rock } \\
\text { slumps in } \\
\text { Creta- } \\
\text { ceous } \\
\text { shale }\end{array}$ & $\begin{array}{l}\text { Both } \\
\text { abutments }\end{array}$ & $\begin{array}{l}\text { Since construction, small slides have occurred } \\
\text { in both abutments (but especially in the right) in } \\
\text { unconsolidated materials derived from mudstone, } \\
\text { shale, and sandstone. Greatest movement was in } \\
1957 \text { and } 1969 \text {; only minor activity at present. } \\
\text { Movement and seepage are monitored. }\end{array}$ & $\begin{array}{l}\text { Everitt and Schus- } \\
\text { ter (1999)/Utah } \\
\text { Geological } \\
\text { Survey; Utah } \\
\text { Division of Water } \\
\text { Resources; U.S. } \\
\text { Geological Survey }\end{array}$ \\
\hline $\begin{array}{l}\text { United States/ } \\
\text { Utah/ } \\
39.29 \mathrm{~N}, 111.27 \mathrm{~W}\end{array}$ & $\begin{array}{l}\text { Joes Valley/ } \\
\text { Seely Creek }\end{array}$ & $\begin{array}{l}\text { Earthfill/ } \\
\text { Irrigation, } \\
\text { recreation, fish } \\
\text { and wildlife, } \\
\text { flood control }\end{array}$ & $\begin{array}{l}\text { 1966/Federal } \\
\text { government }\end{array}$ & $58 / 229$ & 77 & $\begin{array}{l}\text { Slide in } \\
\text { sandstone- } \\
\text { shale } \\
\text { colluvium } \\
\text { and talus }\end{array}$ & $\begin{array}{l}\text { Both } \\
\text { abutments }\end{array}$ & $\begin{array}{l}\text { Impervious cutoff to bedrock through about } 10 \\
\mathrm{~m} \text { of colluvium/talus cover at both abutments. } \\
\text { Part of colluvium/talus left in place and shaped } \\
\text { on downstream parts of both abutments. Slide } \\
\text { in talus of right abutment during construction. } \\
\text { Earthquake-induced slide occurred in right-abut- } \\
\text { ment talus in 1988; cracks remain in abutment } \\
\text { area. Seepage in right-abutment slide area. } \\
\text { Seepage collection pipes, collection wells, and } \\
\text { seepage monitoring points have been installed. }\end{array}$ & $\begin{array}{l}\text { None/U.S. Bureau } \\
\text { of Reclamation } \\
\text { reports }\end{array}$ \\
\hline $\begin{array}{l}\text { United States/ } \\
\text { Utah/ } \\
40.41 \mathrm{~N}, 111.71 \mathrm{~W}\end{array}$ & $\begin{array}{l}\text { Jordanelle/ } \\
\text { Provo River }\end{array}$ & $\begin{array}{l}\text { Earthfill/ } \\
\text { Water supply }\end{array}$ & $\begin{array}{l}\text { 1993/Federal } \\
\text { government }\end{array}$ & $\begin{array}{l}119 / \\
1,164\end{array}$ & 448 & $\begin{array}{l}\text { Rock- } \\
\text { block } \\
\text { slide in } \\
\text { Tertiary } \\
\text { volcanics }\end{array}$ & $\begin{array}{l}\text { Left } \\
\text { abutment }\end{array}$ & $\begin{array}{l}\text { Andesite-porphyry rock-block slide (volume } \\
\sim 75,000 \mathrm{~m}^{3} \text { ) found in left abutment during } \\
\text { construction. Location of slide was centerline } \\
\text { to downstream toe. Most was removed. "Dental } \\
\text { work" assured stability during construction. Lat- } \\
\text { er, buttressing effect of dam provided stability. }\end{array}$ & $\begin{array}{l}\text { Machette and } \\
\text { others (1991), } \\
\text { Dow (1995), } \\
\text { Everitt and } \\
\text { Schuster (1999)/ } \\
\text { U.S. Bureau of } \\
\text { Reclamation }\end{array}$ \\
\hline $\begin{array}{l}\text { United States/ } \\
\text { Utah/ } \\
40.91 \mathrm{~N}, 109.87 \mathrm{~W}\end{array}$ & $\begin{array}{l}\text { Long Park/ } \\
\text { Sheep Creek }\end{array}$ & $\begin{array}{l}\text { Earthfill/ } \\
\text { Irrigation }\end{array}$ & $\begin{array}{l}\text { 1980/Private } \\
\text { irrigation } \\
\text { company }\end{array}$ & $35 / 262$ & 18.0 & $\begin{array}{l}\text { Bedding- } \\
\text { plane } \\
\text { creep in } \\
\text { sandstone/ } \\
\text { shale }\end{array}$ & $\begin{array}{l}\text { Left } \\
\text { abutment }\end{array}$ & $\begin{array}{l}\text { Joints in sandstone/shale left abutment open } \\
\text { as much as } 0.75 \mathrm{~m} \text { due to bedding-plane creep } \\
\text { resulting from stress relief. Open joints were } \\
\text { grouted (triple-line grout) during construction; } \\
\text { however, seepage occurred through left abutment. } \\
\text { In late } 1990 \mathrm{~s} \text {, a } 20 \text {-m-deep concrete cutoff wall } \\
\text { was placed through the open-jointed rock to stop } \\
\text { seepage. }\end{array}$ & $\begin{array}{l}\text { Forrest and } \\
\text { others }(2001) / \text { U.S. } \\
\text { Natural Resources } \\
\text { Conservation } \\
\text { Service }\end{array}$ \\
\hline
\end{tabular}


Appendix table A. Dam characteristics, relation to landslides, mitigative measures, and cited references-Continued.

\begin{tabular}{|c|c|c|c|c|c|c|c|c|c|}
\hline $\begin{array}{l}\text { Country/ } \\
\text { state } \\
\text { or province/ } \\
\text { latitude, } \\
\text { longitude }\end{array}$ & $\begin{array}{l}\text { Dam/river } \\
\text { or stream }\end{array}$ & $\begin{array}{l}\text { Dam type/ } \\
\text { purpose }\end{array}$ & $\begin{array}{l}\text { Year } \\
\text { constructed/ } \\
\text { owner }\end{array}$ & $\begin{array}{l}\text { Height/ } \\
\text { length } \\
\text { (m) }\end{array}$ & $\begin{array}{c}\text { Storage } \\
\text { volume } \\
\left(\mathrm{Mm}^{3}\right)\end{array}$ & $\begin{array}{l}\text { Landslide } \\
\text { type }\end{array}$ & $\begin{array}{l}\text { Landslide } \\
\text { position } \\
\text { relative to } \\
\text { dam }\end{array}$ & Comments & $\begin{array}{l}\text { References/ } \\
\text { sources } \\
\text { of } \\
\text { information }\end{array}$ \\
\hline $\begin{array}{l}\text { United States/ } \\
\text { Utah/ } \\
37.86 \mathrm{~N}, 109.36 \mathrm{~W}\end{array}$ & $\begin{array}{l}\text { Loyd's Lake/ } \\
\text { South and } \\
\text { Pole Creeks }\end{array}$ & $\begin{array}{l}\text { Earthfill/ } \\
\text { Irrigation }\end{array}$ & 1984/Private & $23 / 457$ & 5.3 & $\begin{array}{l}\text { Slump in } \\
\text { Creta- } \\
\text { ceous } \\
\text { shale }\end{array}$ & $\begin{array}{l}\text { Right } \\
\text { abutment }\end{array}$ & $\begin{array}{l}\text { Abutment is marginally stable. Berm serves as } \\
\text { buttress. Blanket drain underneath. Piezometers } \\
\text { installed. }\end{array}$ & $\begin{array}{l}\text { Harty (1991), Everitt } \\
\text { and Schuster (1999)/ } \\
\text { Utah Division of } \\
\text { Water Resources; } \\
\text { consultants' reports }\end{array}$ \\
\hline $\begin{array}{l}\text { United States/ } \\
\text { Utah/ } \\
40.49 \mathrm{~N}, 111.10 \mathrm{~W}\end{array}$ & $\begin{array}{l}\text { Mill Hollow/ } \\
\text { Mill Hollow } \\
\text { Creek }\end{array}$ & $\begin{array}{l}\text { Earthfill/ } \\
\text { Recreation }\end{array}$ & $\begin{array}{l}\text { 1962/State } \\
\text { government }\end{array}$ & $13 / 69$ & 0.50 & $\begin{array}{l}\text { Earth- } \\
\text { flow or } \\
\text { compound } \\
\text { slump }\end{array}$ & $\begin{array}{l}\text { Right } \\
\text { abutment }\end{array}$ & $\begin{array}{l}\text { Toe of large "earthflow or compound slump" } \\
\text { in Tertiary volcanics forms the right abutment. } \\
\text { Apparently, this landslide at one time dammed } \\
\text { the creek, which has since eroded a small canyon } \\
\text { through the landslide dam. Mill Hollow Dam } \\
\text { was built in this canyon. Landslide has caused no } \\
\text { problems to dam. }\end{array}$ & $\begin{array}{l}\text { Everitt and } \\
\text { Schuster (1999)/ } \\
\text { Utah Division of } \\
\text { Water Resources }\end{array}$ \\
\hline $\begin{array}{l}\text { United States/ } \\
\text { Utah/ } \\
40.56 \mathrm{~N}, 110.49 \mathrm{~W}\end{array}$ & $\begin{array}{l}\text { Moon Lake/ } \\
\text { Lake Fork } \\
\text { River }\end{array}$ & $\begin{array}{l}\text { Earthfill/ } \\
\text { Irrigation }\end{array}$ & $\begin{array}{l}\text { 1938/Federal } \\
\text { government }\end{array}$ & $46 / 338$ & 61.0 & $\begin{array}{l}\text { Block } \\
\text { slide in } \\
\text { Precam- } \\
\text { brian } \\
\text { shale }\end{array}$ & $\begin{array}{l}\text { Left } \\
\text { abutment }\end{array}$ & $\begin{array}{l}\text { Left end of dam rests on landslide block. Cutoff } \\
\text { trench was dug though block into in-place shale. } \\
\text { Disturbed shale heavily grouted. Dam is stable. }\end{array}$ & $\begin{array}{l}\text { Harty (1991), Everitt } \\
\text { and Schuster (1999)/ } \\
\text { U.S. Bureau of Rec- } \\
\text { lamation }\end{array}$ \\
\hline $\begin{array}{l}\text { United States/ } \\
\text { Utah/ } \\
41.90 \mathrm{~N}, 111.98 \mathrm{~W}\end{array}$ & $\begin{array}{l}\text { Newton/ } \\
\text { Clarkston } \\
\text { Creek }\end{array}$ & $\begin{array}{l}\text { Earthfill/ } \\
\text { Irrigation }\end{array}$ & $\begin{array}{l}\text { 1946/Federal } \\
\text { government }\end{array}$ & $\begin{array}{l}32 / \\
1,018\end{array}$ & 6.9 & $\begin{array}{l}\text { Deep- } \\
\text { seated } \\
\text { earth slide }\end{array}$ & $\begin{array}{l}\text { Left } \\
\text { abutment }\end{array}$ & $\begin{array}{l}\text { Abutment is in earth-slide material derived from } \\
\text { upslope shale. No serious problems. }\end{array}$ & $\begin{array}{l}\text { Harty (1991), Everitt } \\
\text { and Schuster (1999), } \\
\text { Solomon (1999)/ } \\
\text { None }\end{array}$ \\
\hline $\begin{array}{l}\text { United States/ } \\
\text { Utah/ } \\
37.66 \mathrm{~N}, 109.44 \mathrm{~W}\end{array}$ & $\begin{array}{l}\text { Recapture/ } \\
\text { Recapture } \\
\text { Creek }\end{array}$ & $\begin{array}{l}\text { Earthfill/ } \\
\text { Irrigation }\end{array}$ & 1984/Private & $43 / 884$ & 19.7 & $\begin{array}{l}\text { Small } \\
\text { slump in } \\
\text { Jurassic } \\
\text { shale }\end{array}$ & $\begin{array}{l}\text { Both } \\
\text { abutments }\end{array}$ & $\begin{array}{l}\text { Abutments were formed of ancient, opposing } \\
\text { landslides that were noted prior to construction. } \\
\text { During construction of cutoff, left-abutment slide } \\
\text { was reactivated. Cutoff extends to bedrock under } \\
\text { center core of dam, leaving slide remnants under } \\
\text { upstream and downstream parts of dam. }\end{array}$ & $\begin{array}{l}\text { Montgomery (1980), } \\
\text { Everitt (1993), } \\
\text { Everitt and Schuster } \\
\text { (1999)/Utah Divi- } \\
\text { sion of Water Re- } \\
\text { sources; consultant's } \\
\text { report }\end{array}$ \\
\hline $\begin{array}{l}\text { United States/ } \\
\text { Utah/ } \\
37.87 \mathrm{~N}, 112.68 \mathrm{~W}\end{array}$ & $\begin{array}{l}\text { Red Creek/ } \\
\text { Red Creek }\end{array}$ & $\begin{array}{l}\text { Earthfill/ } \\
\text { Irrigation }\end{array}$ & 1980/Private & $23 / 259$ & 23.4 & $\begin{array}{l}\text { Large } \\
\text { earth slide } \\
\text { in Tertiary } \\
\text { volcanics }\end{array}$ & $\begin{array}{l}\text { Left abut- } \\
\text { ment }\end{array}$ & $\begin{array}{l}\text { Left abutment and reservoir shore underlain by } \\
\text { large Holocene/late Pleistocene slide (thickness: } \\
\sim 60 \mathrm{~m} \text { ), mainly weathered volcanics. Dam but- } \\
\text { tresses toe of slide. No problems. }\end{array}$ & $\begin{array}{l}\text { Everitt and Schus- } \\
\text { ter (1999)/Utah } \\
\text { Division of Water } \\
\text { Resources }\end{array}$ \\
\hline
\end{tabular}


Appendix table A. Dam characteristics, relation to landslides, mitigative measures, and cited references-Continued.

\begin{tabular}{|c|c|c|c|c|c|c|c|c|c|}
\hline $\begin{array}{l}\text { Country/ } \\
\text { state } \\
\text { or province/ } \\
\text { latitude, } \\
\text { longitude }\end{array}$ & $\begin{array}{l}\text { Dam/river } \\
\text { or stream }\end{array}$ & $\begin{array}{c}\text { Dam type/ } \\
\text { purpose }\end{array}$ & $\begin{array}{c}\text { Year } \\
\text { constructed/ } \\
\text { owner }\end{array}$ & $\begin{array}{l}\text { Height/ } \\
\text { length } \\
\text { (m) }\end{array}$ & $\begin{array}{c}\text { Storage } \\
\text { volume } \\
\left(\mathrm{Mm}^{3}\right)\end{array}$ & $\begin{array}{l}\text { Landslide } \\
\text { type }\end{array}$ & $\begin{array}{l}\text { Landslide } \\
\text { position } \\
\text { relative to } \\
\text { dam }\end{array}$ & Comments & $\begin{array}{c}\text { References/ } \\
\text { sources } \\
\text { of } \\
\text { information }\end{array}$ \\
\hline $\begin{array}{l}\text { United States/ } \\
\text { Utah/ } \\
40.76 \mathrm{~N}, 111.10 \mathrm{~W}\end{array}$ & $\begin{array}{l}\text { Smith and } \\
\text { Morehouse/ } \\
\text { Smith and } \\
\text { Morehouse } \\
\text { Creek }\end{array}$ & $\begin{array}{l}\text { Earthfill/ } \\
\text { Irrigation }\end{array}$ & $\begin{array}{l}\text { 1987/Private } \\
\text { irrigation } \\
\text { district }\end{array}$ & $25 / 670$ & 12.4 & $\begin{array}{l}\text { Valley- } \\
\text { wide } \\
\text { debris } \\
\text { avalanche }\end{array}$ & $\begin{array}{l}\text { Foundation, } \\
\text { both abut- } \\
\text { ments }\end{array}$ & $\begin{array}{l}\text { Large avalanche (age } \sim 4,000 \mathrm{yr} \text { B.P.) in sedi- } \\
\text { mentary rock and glacial debris filled canyon } \\
\text { to depth of } 60 \mathrm{~m} \text {. Dam built on debris, but key } \\
\text { placed through the mass both for strength and } \\
\text { imperviousness. No problems. }\end{array}$ & $\begin{array}{l}\text { Harty (1991), Everitt } \\
\text { and Schuster (1999)/ } \\
\text { Utah Division of } \\
\text { Water Resources }\end{array}$ \\
\hline $\begin{array}{l}\text { United States/ } \\
\text { Utah/ } \\
37.14 \mathrm{~N}, 112.90 \mathrm{~W}\end{array}$ & $\begin{array}{l}\text { South Creek/ } \\
\text { South Creek }\end{array}$ & $\begin{array}{l}\text { Earthfill/ } \\
\text { Irrigation }\end{array}$ & 1988/Private & $21 / 226$ & 2.2 & $\begin{array}{l}\text { Large } \\
\text { slump in } \\
\text { Triassic } \\
\text { shale }\end{array}$ & $\begin{array}{l}\text { Right } \\
\text { abutment }\end{array}$ & $\begin{array}{l}\text { Right abutment is slump block of sandstone, } \\
\text { siltstone, and shale. Small slide shortly after res- } \\
\text { ervoir filling. Remedial measures: (1) collection- } \\
\text { drain system, (2) impervious seepage blanket, } \\
\text { and (3) horizontal drains. }\end{array}$ & $\begin{array}{l}\text { Harty (1991), Everitt } \\
\text { and Schuster (1999)/ } \\
\text { Utah Division of } \\
\text { Water Resources; } \\
\text { consultants' reports }\end{array}$ \\
\hline $\begin{array}{l}\text { United States/ } \\
\text { Utah/ } \\
37.76 \mathrm{~N}, 112.77 \mathrm{~W}\end{array}$ & $\begin{array}{l}\text { Yankee } \\
\text { Meadows/ } \\
\text { Bowery } \\
\text { Creek }\end{array}$ & $\begin{array}{l}\text { Earthfill/ } \\
\text { Irrigation }\end{array}$ & 1926/Private & $10 / 137$ & 1.27 & $\begin{array}{l}\text { Large } \\
\text { slide in } \\
\text { Tertiary } \\
\text { volcanics }\end{array}$ & $\begin{array}{l}\text { Right } \\
\text { abutment }\end{array}$ & $\begin{array}{l}\text { Dam is on toe of very large slide (gravitational } \\
\text { or tectonic) from valley wall. Slide has had no } \\
\text { negative effect on dam performance. }\end{array}$ & $\begin{array}{l}\text { Everitt and Schuster } \\
\text { (1999)/Utah Division } \\
\text { of Water Resources }\end{array}$ \\
\hline $\begin{array}{l}\text { United States/ } \\
\text { Vermont/ } \\
44.38 \mathrm{~N}, 72.77 \mathrm{~W}\end{array}$ & $\begin{array}{l}\text { Waterbury/ } \\
\text { Little River }\end{array}$ & $\begin{array}{l}\text { Earthfill/ } \\
\text { Flood } \\
\text { control, } \\
\text { recreation, } \\
\text { hydroelectric }\end{array}$ & $\begin{array}{l}\text { 1938/State } \\
\text { government }\end{array}$ & $57 / 649$ & 98.4 & Rock fall & Foundation & $\begin{array}{l}\text { Part of foundation located in narrow bedrock } \\
\text { gorge. "Detached rock slabs along the right } \\
\text { (west) side of the gorge form a roof over a } \\
\text { piping tunnel known to have been a piping } \\
\text { path in the past, and capable of being a piping } \\
\text { path in the future if injected filter materials are } \\
\text { destabilized" (Saber and others, 2001). Grouting } \\
\text { program to prevent seepage was completed in } \\
\text { 1985. Apparently, some seepage continues. }\end{array}$ & $\begin{array}{l}\text { Saber and others } \\
\text { (2001)/U.S. Army } \\
\text { Corps of Engineers; } \\
\text { Vermont Department } \\
\text { of Environmental } \\
\text { Conservation }\end{array}$ \\
\hline $\begin{array}{l}\text { United States/ } \\
\text { Washington/ } \\
45.64 \mathrm{~N}, 121.93 \mathrm{~W}\end{array}$ & $\begin{array}{l}\text { Bonneville/ } \\
\text { Columbia } \\
\text { River }\end{array}$ & $\begin{array}{l}\text { Concrete } \\
\text { gravity/ } \\
\text { Hydro- } \\
\text { electric, } \\
\text { navigation, } \\
\text { recreation }\end{array}$ & $\begin{array}{l}\text { 1937/Federal } \\
\text { government }\end{array}$ & $60 / 755$ & 710 & $\begin{array}{l}\text { Large } \\
\text { prehistoric } \\
\text { landslide }\end{array}$ & $\begin{array}{l}\text { Right } \\
\text { abutment }\end{array}$ & $\begin{array}{l}\text { Right abutment is toe of huge Bonneville land- } \\
\text { slide (age } 400 \text { yr B.P.). Minor surficial move- } \\
\text { ment currently occurring locally on the slide, } \\
\text { but not at abutment location. Toe of slide is large } \\
\text { and stable. No problems. Note: south end of the } \\
\text { dam (navigation locks) also is on a pre-existing } \\
\text { landslide (smaller than the Bonneville slide). } \\
\text { Local problems during construction, but none at } \\
\text { present. }\end{array}$ & $\begin{array}{l}\text { Palmer (1977), Sager } \\
(1989), \text { Keech and } \\
\text { Sanford (1998)/U.S. } \\
\text { Army Corps of Engi- } \\
\text { neers. }\end{array}$ \\
\hline
\end{tabular}


Appendix table A. Dam characteristics, relation to landslides, mitigative measures, and cited references-Continued.

\begin{tabular}{|c|c|c|c|c|c|c|c|c|c|}
\hline $\begin{array}{l}\text { Country/ } \\
\text { state } \\
\text { or province/ } \\
\text { latitude, } \\
\text { longitude }\end{array}$ & $\begin{array}{l}\text { Dam/river } \\
\text { or stream }\end{array}$ & $\begin{array}{c}\text { Dam type/ } \\
\text { purpose }\end{array}$ & $\begin{array}{l}\text { Year } \\
\text { constructed/ } \\
\text { owner }\end{array}$ & $\begin{array}{l}\text { Height/ } \\
\text { length } \\
\text { (m) }\end{array}$ & $\begin{array}{c}\text { Storage } \\
\text { volume } \\
\left(\mathrm{Mm}^{3}\right)\end{array}$ & $\begin{array}{l}\text { Landslide } \\
\text { type }\end{array}$ & $\begin{array}{l}\text { Landslide } \\
\text { position } \\
\text { relative to } \\
\text { dam }\end{array}$ & Comments & $\begin{array}{l}\text { References/ } \\
\text { sources } \\
\text { of } \\
\text { information }\end{array}$ \\
\hline $\begin{array}{l}\text { United States/ } \\
\text { Washington/ } \\
46.87 \mathrm{~N}, 121.30 \mathrm{~W}\end{array}$ & $\begin{array}{l}\text { Bumping } \\
\text { Lake/ } \\
\text { Bumping } \\
\text { River }\end{array}$ & $\begin{array}{l}\text { Earthfill/ } \\
\text { Irrigation }\end{array}$ & $\begin{array}{l}\text { 1910/Federal } \\
\text { government }\end{array}$ & $19 / 892$ & 46.5 & $\begin{array}{l}\text { Volcanic } \\
\text { debris } \\
\text { flow } \\
\text { (lahar) }\end{array}$ & $\begin{array}{l}\text { Entire } \\
\text { foundaion }\end{array}$ & $\begin{array}{l}\text { Dam was unknowingly built on a 1-2-m-thick } \\
\text { lahar (age } ~ 500 \text { yr B.P.) from Mount Rainier. } \\
\text { Considerable seepage through foundation. In } \\
\text { 1990s, drainage trench and stability berm were } \\
\text { constructed at downstream toe of dam. }\end{array}$ & $\begin{array}{l}\text { None/U.S. Bureau } \\
\text { of Reclamation }\end{array}$ \\
\hline $\begin{array}{l}\text { United States/ } \\
\text { Washington/ } \\
48.00 \mathrm{~N}, 123.62 \mathrm{~W}\end{array}$ & $\begin{array}{l}\text { Glines } \\
\text { Canyon/ } \\
\text { Elwha River }\end{array}$ & $\begin{array}{l}\text { Left wing } \\
\text { wall: earthfill/ } \\
\text { Hydroelectric }\end{array}$ & 1927/Private & $\begin{array}{l}\text { Wing- } \\
\text { wall } \\
\text { height: } \\
10-15 \mathrm{~m}\end{array}$ & 49.3 & $\begin{array}{l}\text { Rock/soil } \\
\text { slide }\end{array}$ & $\begin{array}{l}\text { Left end of } \\
\text { wingwall }\end{array}$ & $\begin{array}{l}\text { Field visit confirmed that left end of earthfill } \\
\text { left wingwall (or saddle dam) of this 59-m-high } \\
\text { concrete arch dam abuts a surficial rock/soil } \\
\text { slide. No problems. }\end{array}$ & $\begin{array}{l}\text { None/K.G. Neal } \\
\text { (written commun., } \\
\text { 2001) }\end{array}$ \\
\hline $\begin{array}{l}\text { United States/ } \\
\text { Washington/ } \\
47.96 \mathrm{~N}, 118.98 \mathrm{~W}\end{array}$ & $\begin{array}{l}\text { Grand Cou- } \\
\text { lee/ } \\
\text { Columbia } \\
\text { River }\end{array}$ & $\begin{array}{l}\text { Concrete grav- } \\
\text { ity/Irrigation, } \\
\text { hydroelectric, } \\
\text { flood control }\end{array}$ & $\begin{array}{l}\text { 1942/Federal } \\
\text { government }\end{array}$ & $\begin{array}{l}168 / \\
1,729\end{array}$ & 11,780 & Soil slide & $\begin{array}{l}\text { Right } \\
\text { abutment }\end{array}$ & $\begin{array}{l}\text { Varved clay at right abutment moved during } \\
\text { construction. Stabilized by (1) building timber- } \\
\text { crib retaining wall, (2) flattening the slope, } \\
\text { and (3) freezing the soil above the wall. This } \\
\text { soil-slide area was removed in } 1967-81 \text { when } \\
\text { dam was lengthened to accommodate third } \\
\text { powerplant. }\end{array}$ & $\begin{array}{l}\text { Gordon (1937), } \\
\text { Irwin (1938)/U.S. } \\
\text { Bureau of } \\
\text { Reclamation }\end{array}$ \\
\hline $\begin{array}{l}\text { United States/ } \\
\text { Washington/ } \\
47.27 \mathrm{~N}, 121.79 \mathrm{~W}\end{array}$ & $\begin{array}{l}\text { Howard A. } \\
\text { Hanson/ } \\
\text { Green River }\end{array}$ & $\begin{array}{l}\text { Rockfill and } \\
\text { earthfill/Flood } \\
\text { control }\end{array}$ & $\begin{array}{l}\text { 1962/Federal } \\
\text { government }\end{array}$ & $72 / 152$ & 169 & $\begin{array}{l}\text { Large } \\
\text { landslide } \\
\text { (area: } \\
>400 \mathrm{~m} \times \\
600 \mathrm{~m} \text { ) }\end{array}$ & $\begin{array}{l}\text { Right } \\
\text { abutment }\end{array}$ & $\begin{array}{l}\text { Gorge of Green River was cut into toe of a } \\
\text { massive Pleistocene slide. Right end of dam is } \\
\text { built on landslide deposits consisting of rock } \\
\text { blocks up to } 6 \mathrm{~m} \text { in diameter and finer debris. } \\
\text { Considerable seepage through right abutment. } \\
\text { Remedial measures: (1) gravel drainage blan- } \\
\text { ket, (2) horizontal drains, (3) drainage adit, and } \\
\text { (4) relief wells. }\end{array}$ & $\begin{array}{l}\text { Galster (1989a), } \\
\text { Tabor and others } \\
\text { (2000)/U.S. Army } \\
\text { Corps of Engi- } \\
\text { neers; Washing- } \\
\text { ton Division of } \\
\text { Geology and Earth } \\
\text { Resources }\end{array}$ \\
\hline $\begin{array}{l}\text { United States/ } \\
\text { Washington/ } \\
47.14 \mathrm{~N}, 121.93 \mathrm{~W}\end{array}$ & $\begin{array}{l}\text { Mud Moun- } \\
\text { tain/ } \\
\text { White River }\end{array}$ & $\begin{array}{l}\text { Earthfill/ } \\
\text { Flood control }\end{array}$ & $\begin{array}{l}\text { 1948/Federal } \\
\text { government }\end{array}$ & $130 / 213$ & 131 & $\begin{array}{l}\text { Volcanic } \\
\text { debris } \\
\text { flow } \\
\text { (lahar) }\end{array}$ & $\begin{array}{l}\text { Both } \\
\text { abutments }\end{array}$ & $\begin{array}{l}\text { At both banks, dam abuts into Pleistocene lahar } \\
\text { (originally thought to be glacial till). Concrete } \\
\text { cutoff wall installed in } 1989-90 \text { through em- } \\
\text { bankment and into rock foundation to control } \\
\text { seepage. }\end{array}$ & $\begin{array}{l}\text { Galster, R.W. } \\
\text { (1989b), Graybeal } \\
(1991), \text { Eckerlin } \\
(1992,1993) / \text { None }\end{array}$ \\
\hline
\end{tabular}


Appendix table A. Dam characteristics, relation to landslides, mitigative measures, and cited references-Continued.

\begin{tabular}{|c|c|c|c|c|c|c|c|c|c|}
\hline $\begin{array}{l}\text { Country/ } \\
\text { state } \\
\text { or province/ } \\
\text { latitude, } \\
\text { longitude }\end{array}$ & $\begin{array}{l}\text { Dam/river } \\
\text { or stream }\end{array}$ & $\begin{array}{l}\text { Dam type/ } \\
\text { purpose }\end{array}$ & $\begin{array}{c}\text { Year } \\
\text { constructed/ } \\
\text { owner }\end{array}$ & $\begin{array}{l}\text { Height/ } \\
\text { length } \\
\text { (m) }\end{array}$ & $\begin{array}{c}\text { Storage } \\
\text { volume } \\
\left(\mathrm{Mm}^{3}\right)\end{array}$ & $\begin{array}{l}\text { Landslide } \\
\text { type }\end{array}$ & $\begin{array}{l}\text { Landslide } \\
\text { position } \\
\text { relative to } \\
\text { dam }\end{array}$ & Comments & $\begin{array}{l}\text { References/ } \\
\text { sources } \\
\text { of } \\
\text { information }\end{array}$ \\
\hline $\begin{array}{l}\text { United States/ } \\
\text { Washington/ } \\
47.94 \mathrm{~N}, 119.02 \mathrm{~W}\end{array}$ & $\begin{array}{l}\text { North (Banks } \\
\text { Lake)/Upper } \\
\text { Grand Coulee } \\
\text { River }\end{array}$ & $\begin{array}{l}\text { Rockfill and } \\
\text { earthfill/ } \\
\text { Flood control, } \\
\text { navigation, } \\
\text { irrigation, } \\
\text { hydroelectric }\end{array}$ & $\begin{array}{l}\text { 1951/Federal } \\
\text { government }\end{array}$ & $44 / 442$ & 1,572 & $\begin{array}{l}\text { Rotated } \\
\text { slide } \\
\text { block }\end{array}$ & $\begin{array}{l}\text { Left } \\
\text { abutment }\end{array}$ & $\begin{array}{l}\text { Left abutment is a rotated slide-block segment } \\
\text { of a basalt flow resting on slide-disturbed soft } \\
\text { sediments. The left two-thirds of the dam rests } \\
\text { on these slide-disturbed sediments. Cutoff trench } \\
\text { was excavated through these materials. No } \\
\text { operational problems. }\end{array}$ & $\begin{array}{l}\text { Neff (1989), Gu- } \\
\text { lick and Korosec } \\
(1990), \text { Stoffel and } \\
\text { others (1991)/U.S. } \\
\text { Bureau of Recla- } \\
\text { mation }\end{array}$ \\
\hline $\begin{array}{l}\text { United States/ } \\
\text { Washington/ } \\
46.36 \mathrm{~N}, 122.55 \mathrm{~W}\end{array}$ & $\begin{array}{l}\text { SRS (Sedi- } \\
\text { ment reten- } \\
\text { tion struc- } \\
\text { ture)/North } \\
\text { Fork Toutle } \\
\text { River }\end{array}$ & $\begin{array}{l}\text { Earthfill/ } \\
\text { Debris reten- } \\
\text { tion }\end{array}$ & $\begin{array}{l}\text { 1988/Federal } \\
\text { government }\end{array}$ & $73 / 549$ & 197 & $\begin{array}{l}\text { Debris } \\
\text { flow }\end{array}$ & $\begin{array}{l}\text { Entire } \\
\text { dam }\end{array}$ & $\begin{array}{l}\text { Dam was built on at least } 30 \mathrm{~m} \text { of debris-flow } \\
\text { deposits from prehistoric eruptions of Mount St. } \\
\text { Helens. Purpose is to retain sediment derived } \\
\text { from the } 1980 \text { Mount St. Helens debris ava- } \\
\text { lanche. In wet winters of } 1996-97 \text {, dam retained } \\
23 \text { million } \mathrm{m}^{3} \text { of sediment. }\end{array}$ & $\begin{array}{l}\text { Schuster (1989), } \\
\text { Bernton (2000)/ } \\
\text { U.S. Army Corps } \\
\text { of Engineers }\end{array}$ \\
\hline $\begin{array}{l}\text { United States/ } \\
\text { Washington/ } \\
47.31 \mathrm{~N}, 120.31 \mathrm{~W}\end{array}$ & $\begin{array}{l}\text { Stemilt Main } \\
\text { Dam/Orr } \\
\text { Creek-off- } \\
\text { stream }\end{array}$ & $\begin{array}{l}\text { Earthfill/ } \\
\text { Irrigation }\end{array}$ & $\begin{array}{l}\text { 1962/Private } \\
\text { irrigation } \\
\text { district }\end{array}$ & $20 / 305$ & 0.72 & $\begin{array}{l}\text { Massive } \\
\text { landslide }\end{array}$ & $\begin{array}{l}\text { Entire dam } \\
\text { and reservoir }\end{array}$ & $\begin{array}{l}\text { Entire dam and reservoir built on series of mas- } \\
\text { sive landslides (basalt over clay shale) collec- } \\
\text { tively about } 17 \mathrm{~km} \text { long by } 5 \mathrm{~km} \text { wide. Reservoir } \\
\text { leaked considerably through landslide material } \\
\text { until impervious geosynthetic membrane was } \\
\text { successfully placed in } 1986 .\end{array}$ & $\begin{array}{l}\text { Tabor and others } \\
(1982), \text { Stoffel } \\
\text { and others (1991)/ } \\
\text { Washington State } \\
\text { Department of } \\
\text { Ecology }\end{array}$ \\
\hline $\begin{array}{l}\text { United States/ } \\
\text { Washington/ } \\
46.08 \mathrm{~N}, 122.21 \mathrm{~W}\end{array}$ & $\begin{array}{l}\text { Swift/ } \\
\text { Lewis River }\end{array}$ & $\begin{array}{l}\text { Earthfill/ } \\
\text { Hydroelectric, } \\
\text { flood control, } \\
\text { recreation }\end{array}$ & $\begin{array}{l}\text { 1958/Private } \\
\text { power com- } \\
\text { pany }\end{array}$ & $126 / 640$ & 931 & $\begin{array}{l}\text { Volcanic } \\
\text { debris } \\
\text { flow }\end{array}$ & $\begin{array}{l}\text { Foundation } \\
\text { and right } \\
\text { abutment }\end{array}$ & $\begin{array}{l}\text { Right abutment and channel bottom consist of } \\
\text { thick, well-consolidated volcanic debris flow } \\
\text { from prehistoric eruption of Mount St. Helens. } \\
\text { In the channel, an open-cut excavation for cutoff } \\
\text { was made to a depth of about } 30 \mathrm{~m} \text {; sheet piling } \\
\text { driven from bottom of trench to bedrock ( } 25 \\
\text { m). Dam was built on lahar in right abutment. } \\
\text { Drainage gallery to intercept any seepage. No } \\
\text { apparent problems. }\end{array}$ & $\begin{array}{l}\text { de Luccia (1958), } \\
\text { Jensen (1981), } \\
\text { Tilford and Sul- } \\
\text { livan (1981), Lowe } \\
\text { (1988), Major and } \\
\text { Scott (1988), Bliton } \\
\text { (1989)/N.R. Tilford } \\
\text { (oral commun., } \\
\text { 1996) }\end{array}$ \\
\hline
\end{tabular}


Appendix table A. Dam characteristics, relation to landslides, mitigative measures, and cited references-Continued.

\begin{tabular}{|c|c|c|c|c|c|c|c|c|c|}
\hline $\begin{array}{l}\text { Country/ } \\
\text { state } \\
\text { or province/ } \\
\text { latitude, } \\
\text { longitude }\end{array}$ & $\begin{array}{l}\text { Dam/river } \\
\text { or stream }\end{array}$ & $\begin{array}{c}\text { Dam type/ } \\
\text { purpose }\end{array}$ & $\begin{array}{c}\text { Year } \\
\text { constructed/ } \\
\text { owner }\end{array}$ & $\begin{array}{c}\text { Height/ } \\
\text { length } \\
\text { (m) }\end{array}$ & $\begin{array}{c}\text { Storage } \\
\text { volume } \\
\left(\mathrm{Mm}^{3}\right)\end{array}$ & $\begin{array}{l}\text { Landslide } \\
\text { type }\end{array}$ & $\begin{array}{l}\text { Landslide } \\
\text { position } \\
\text { relative to } \\
\text { dam }\end{array}$ & Comments & $\begin{array}{c}\text { References/ } \\
\text { sources } \\
\text { of } \\
\text { information }\end{array}$ \\
\hline $\begin{array}{l}\text { United States/ } \\
\text { Washington/ } \\
47.28 \mathrm{~N}, 120.36 \mathrm{~W}\end{array}$ & $\begin{array}{l}\text { Upper } \\
\text { Wheeler/ } \\
\text { Orr Creek }\end{array}$ & $\begin{array}{l}\text { Earthfill/ } \\
\text { Irrigation, } \\
\text { recreation }\end{array}$ & $\begin{array}{l}\text { 1922/Private } \\
\text { irrigation } \\
\text { company }\end{array}$ & $20 / 274$ & 0.74 & $\begin{array}{l}\text { Massive } \\
\text { landslide }\end{array}$ & $\begin{array}{l}\text { Entire } \\
\text { dam and } \\
\text { reservoir }\end{array}$ & $\begin{array}{l}\text { Entire dam and reservoir built on series of mas- } \\
\text { sive landslides (basalt over clay shale) collec- } \\
\text { tively about } 17 \mathrm{~km} \text { long by } 5 \mathrm{~km} \text { wide. Minor } \\
\text { leakage at left abutment has been controlled by } \\
\text { installation of drains. }\end{array}$ & $\begin{array}{l}\text { Tabor and others } \\
(1982), \text { Stoffel } \\
\text { and others (1991)/ } \\
\text { Washington State } \\
\text { Department of } \\
\text { Ecology }\end{array}$ \\
\hline $\begin{array}{l}\text { United States/ } \\
\text { Washington/ } \\
46.81 \mathrm{~N}, 120.67 \mathrm{~W}\end{array}$ & $\begin{array}{l}\text { Wenas/ } \\
\text { Wenas Creek }\end{array}$ & $\begin{array}{l}\text { Rockfill and } \\
\text { earthfill/ } \\
\text { Irrigation, } \\
\text { recreation }\end{array}$ & $\begin{array}{l}\text { 1911/Private } \\
\text { irrigation } \\
\text { district }\end{array}$ & $27 / 160$ & 6.78 & $\begin{array}{l}\text { Ancient } \\
\text { large land- } \\
\text { slides }\end{array}$ & $\begin{array}{l}\text { Both } \\
\text { abutments }\end{array}$ & $\begin{array}{l}\text { Both abutments are on ancient (probably pre- } \\
\text { Pleistocene) landslides. Left abutment: steeply } \\
\text { dipping sediments on basalt (neither in place). } \\
\text { Right abutment: lower part of very large land- } \\
\text { slide mass. Both masses are so large that they are } \\
\text { inherently stable. No problems. }\end{array}$ & $\begin{array}{l}\text { Swanson and oth- } \\
\text { ers (1979), Walsh } \\
\text { and others (1987)/ } \\
\text { Washington Divi- } \\
\text { sion of Geology and } \\
\text { Earth Resources }\end{array}$ \\
\hline $\begin{array}{l}\text { United States/ } \\
\text { Washington/ } \\
45.98 \mathrm{~N}, 122.35 \mathrm{~W}\end{array}$ & $\begin{array}{l}\text { Yale/ } \\
\text { Lewis River }\end{array}$ & $\begin{array}{l}\text { Earthfill/ } \\
\text { Hydro- } \\
\text { electric, } \\
\text { flood control, } \\
\text { recreation, } \\
\text { fish and } \\
\text { wildlife }\end{array}$ & $\begin{array}{l}\text { 1953/Private } \\
\text { power com- } \\
\text { pany }\end{array}$ & $98 / 457$ & 496 & $\begin{array}{l}\text { Volcanic } \\
\text { debris } \\
\text { flow } \\
\text { (lahar) }\end{array}$ & $\begin{array}{l}\text { Both } \\
\text { abutments } \\
\text { and pos- } \\
\text { sibly the } \\
\text { foundation }\end{array}$ & $\begin{array}{l}\text { Right abutment: during construction, large basalt } \\
\text { block moved. Partially removed by blasting; } \\
\text { now stabilized by dam. Left abutment: slump } \\
\text { in clayey tuff was removed; joints and "faults" } \\
\text { then developed in overlying basalt. Stabilized by } \\
\text { dam. Tilford and Sullivan (1981) showed lahar in } \\
\text { channel at damsite; apparently, it was removed } \\
\text { under the impervious part of the dam foundation. } \\
\text { Not clear if lahar remains under outer shell. No } \\
\text { problems. }\end{array}$ & $\begin{array}{l}\text { Tilford and Sullivan } \\
\text { (1981), Major and } \\
\text { Scott (1988), Bliton } \\
\text { (1989)/N.R. Tilford } \\
\text { (oral commun., } \\
\text { 1997) }\end{array}$ \\
\hline $\begin{array}{l}\text { United States/ } \\
\text { Washington/ } \\
45.98 \mathrm{~N}, 122.35 \mathrm{~W}\end{array}$ & $\begin{array}{l}\text { Yale Saddle } \\
\text { Dam/Lewis } \\
\text { River }\end{array}$ & $\begin{array}{l}\text { Earthfill/ } \\
\text { Hydro- } \\
\text { electric, } \\
\text { flood control, } \\
\text { recreation, } \\
\text { fish and } \\
\text { wildlife }\end{array}$ & $\begin{array}{l}\text { 1953/Private } \\
\text { power com- } \\
\text { pany }\end{array}$ & $12 / 488$ & 496 & $\begin{array}{l}\text { Volcanic } \\
\text { debris } \\
\text { flow } \\
\text { (lahar) }\end{array}$ & $\begin{array}{l}\text { Entire } \\
\text { dam }\end{array}$ & $\begin{array}{l}\text { Entire saddle dam is founded on volcanic debris } \\
\text { flow (lahar). No problems. }\end{array}$ & $\begin{array}{l}\text { Tilford and Sul- } \\
\text { livan (1981), Bliton } \\
\text { (1989)/N.R. Tilford } \\
\text { (oral commun., } \\
\text { 1997) }\end{array}$ \\
\hline
\end{tabular}


Appendix table A. Dam characteristics, relation to landslides, mitigative measures, and cited references—Continued.

\begin{tabular}{|c|c|c|c|c|c|c|c|c|c|}
\hline $\begin{array}{c}\text { Country/ } \\
\text { state } \\
\text { or province/ } \\
\text { latitude, } \\
\text { longitude }\end{array}$ & $\begin{array}{l}\text { Dam/river } \\
\text { or stream }\end{array}$ & $\begin{array}{c}\text { Dam type/ } \\
\text { purpose }\end{array}$ & $\begin{array}{c}\text { Year } \\
\text { constructed/ } \\
\text { owner }\end{array}$ & $\begin{array}{c}\text { Height/ } \\
\text { length } \\
\text { (m) }\end{array}$ & $\begin{array}{c}\text { Storage } \\
\text { volume } \\
\left(\mathrm{Mm}^{3}\right)\end{array}$ & $\begin{array}{c}\text { Landslide } \\
\text { type }\end{array}$ & $\begin{array}{l}\text { Landslide } \\
\text { position } \\
\text { relative to } \\
\text { dam }\end{array}$ & Comments & $\begin{array}{l}\text { References/ } \\
\text { sources } \\
\text { of } \\
\text { information }\end{array}$ \\
\hline $\begin{array}{l}\text { United States/ } \\
\text { West Virginia/ } \\
39.37 \mathrm{~N}, 81.27 \mathrm{~W}\end{array}$ & $\begin{array}{l}\text { McElroy's } \\
\text { Run/ } \\
\text { McElroy's } \\
\text { Run Creek }\end{array}$ & $\begin{array}{l}\text { Fly-ash } \\
\text { embankment/ } \\
\text { Fly-ash } \\
\text { storage }\end{array}$ & $\begin{array}{l}\text { 1978/Public } \\
\text { utility }\end{array}$ & $74 / 655$ & 24.53 & $\begin{array}{l}\text { Slide in } \\
\text { colluvium }\end{array}$ & $\begin{array}{l}\text { Left } \\
\text { abutment }\end{array}$ & $\begin{array}{l}\text { Before placing fly-ash embankment on down- } \\
\text { stream edge of tailings dam, slide was noted in } \\
\text { colluvium of left abutment. Removal of unstable } \\
\text { material not feasible. Remediation: grid of auger- } \\
\text { cast grout columns was placed through unstable } \\
\text { material. }\end{array}$ & $\begin{array}{l}\text { Newman and } \\
\text { others }(2000) / \\
\text { None }\end{array}$ \\
\hline $\begin{array}{l}\text { United States/ } \\
\text { Wyoming/ } \\
41.03 \mathrm{~N}, 110.58 \mathrm{~W}\end{array}$ & $\begin{array}{l}\text { Meeks Cabin/ } \\
\text { Black Fork } \\
\text { River }\end{array}$ & $\begin{array}{l}\text { Earthfill/ } \\
\text { Irrigation }\end{array}$ & $\begin{array}{l}\text { 1971/Federal } \\
\text { government }\end{array}$ & $59 / 964$ & 47 & $\begin{array}{l}\text { Rock slide } \\
\text { in shale }\end{array}$ & $\begin{array}{l}\text { Right } \\
\text { abutment }\end{array}$ & $\begin{array}{l}\text { Ancient massive (area } \sim 1 \times 0.75 \mathrm{~km} \text { ) shale slide } \\
\text { forms right valley wall. Dam constructed with } \\
\text { deep cutoff trench. No landslide-related stabil- } \\
\text { ity or seepage problems. However, seepage has } \\
\text { occurred through glacial outwash materials in } \\
\text { left abutment, resulting in } 1994 \text { construction of } \\
\text { cutoff wall. }\end{array}$ & $\begin{array}{l}\text { Gagliardi and } \\
\text { Routh (1993)/ } \\
\text { U.S. Bureau of } \\
\text { Reclamation; } \\
\text { Geological } \\
\text { Survey of } \\
\text { Wyoming }\end{array}$ \\
\hline
\end{tabular}


